\title{
CONCEPTUAL EVALUATION OF REGIONAL GROUND-WATER FLOW IN THE CARBONATE-ROCK PROVINCE OF THE GREAT BASIN, NEVADA, UTAH, AND ADJACENT STATES
}

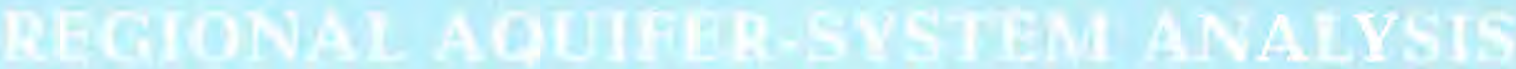

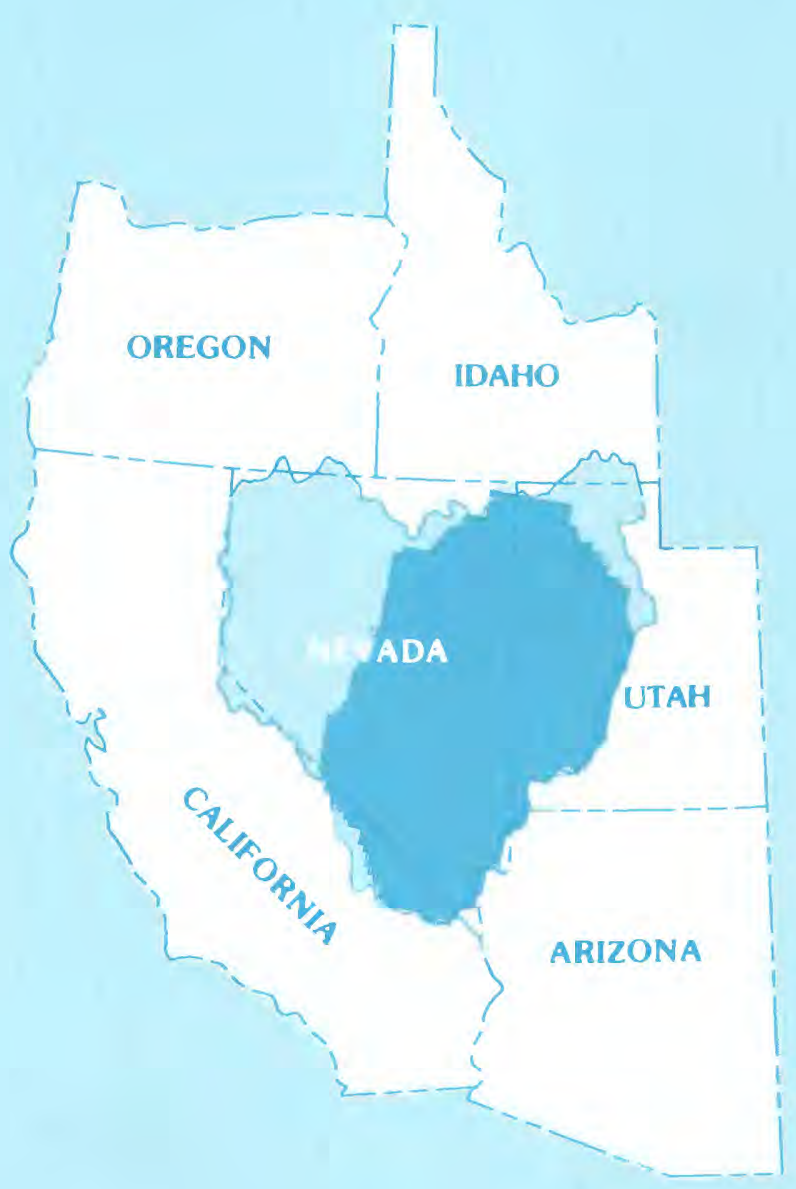


Instructions on ordering publications of the U.S. Geological Survey, along with prices of the last offerings, are given in the currentyear issues of the monthly catalog "New Publications of the U.S. Geological Survey." Prices of available U.S. Geological Survey publications released prior to the current year are listed in the most recent annual "Price and Availability List." Publications that are listed in various U.S. Geological Survey catalogs (see back inside cover) but not listed in the most recent annual "Price and Availability List" are no longer available.

Reports released through the NTIS may be obtained by writing to the National Technical Information Service, U.S. Department of Commerce, Springfield, VA 22161; please include NTIS report number with inquiry.

Order U.S. Geological Survey publications by mail or over the counter from the offices given below.

\section{BY MAIL}

\section{Books}

Professional Papers, Bulletins, Water-Supply Papers, Techniques of Water-Resources Investigations, Circulars, publications of general interest (such as leaflets, pamphlets, booklets), single copies of Earthquakes \& Volcanoes, Preliminary Determination of Epicenters, and some miscellaneous reports, including some of the foregoing series that have gone out of print at the Superintendent of Documents, are obtainable by mail from

\section{U.S. Geological Survey, Information Services Box 25286, Federal Center \\ Denver, CO 80225}

Subscriptions to periodicals (Earthquakes \& Volcanoes and Preliminary Determination of Epicenters) can be obtained ONLY from the

\section{Superintendent of Documents \\ Government Printing Office \\ Washington, DC 20402}

(Check or money order must be payable to Superintendent of Documents.)

\section{Maps}

For maps, address mail orders to

\section{U.S. Geological Survey, Map Distribution Box 25286, Bldg. 810, Federal Center Denver, CO 80225}

Residents of Alaska may order maps from

\author{
U.S. Geological Survey, Earth Science Information Center \\ 101 Twelfth Ave, Box 12 \\ Fairbanks, AK 99701
}

\section{OVER THE COUNTER}

\section{Books and Maps}

Books and maps of the U.S. Geological Survey are available over the counter at the following U.S. Geological Survey offices, all of which are authorized agents of the Superintendent of Documents.

- ANCHORAGE, Alaska-4230 University Dr., Rm. 101

- LAKEWOOD, Colorado-Federal Center, Bldg. 810

- MENLO PARK, California-Bldg. 3, Rm. 3128, 345 Middlefield Rd.

- RESTON, Virginia-National Center, Rm. 1C402, 12201 Sunrise Valley Dr.

- SALT LAKE CITY, Utah-Federal Bldg., Rm. 8105, 125 South State St.

- SPOKANE, Washington-U.S. Post Office Bldg., Rm. 135, W. 904 Riverside Ave.

- WASHINGTON, D.C.-Main Interior Bldg., Rm. 2650, 18th and C Sts., NW.

\section{Maps Only}

Maps may be purchased over the counter at the U.S. Geological Survey offices:

- FAIRBANKS, Alaska-New Federal Building, 101 Twelfth Ave.

- ROLLA, Missouri-1400 Independence Rd.

- STENNIS SPACE CENTER, Mississippi-Bldg. 3101 


\section{ERRATA}

\section{U.S. Geological Survey Professional Paper 1409-D}

The original version of this report was published in September 1991 as a Professional Paper with the same title and number (1409-D). In November 1991, an error in the model was discovered. As a result, the model was corrected and recalibrated. This report, published in 1995, presents the revised model. 



\section{Conceptual Evaluation of Regional Ground-Water}

Flow in the Carbonate-Rock Province of the Great Basin, Nevada, Utah, and Adjacent States

By DAVID E. PRUDIC, JAMES R. HARRILL, and THOMAS J. BURBEY

REGIONAL AQUIFER-SYSTEM ANALYSIS-GREAT BASIN, NEVADA-UTAH

U.S. GEOLOGICAL SURVEY PROFESSIONAL PAPER 1409-D

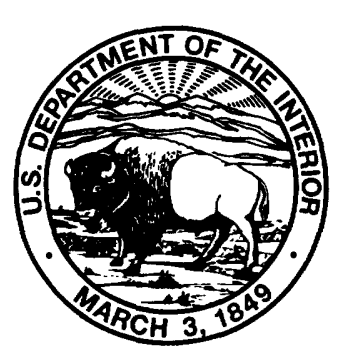

UNITED STATES GOVERNMENT PRINTING OFFICE, WASHINGTON : 1995 


\section{U.S. DEPARTMENT OF THE INTERIOR \\ BRUCE BABBITT, Secretary}

U.S. GEOLOGICAL SURVEY

Gordon P. Eaton, Director

Any use of trade, product, or firm names in this publication

is for descriptive purposes only and does not constitute endorsement by the U.S. Government

\section{Library of Congress Cataloging-in-Publication Data}

Prudic, David E.

Conceptual evaluation of regional ground-water flow in the carbonate-rock province of the Great Basin, Nevada, Utah, and adjacent states / by David E. Prudic, James R. Harrill, and Thomas J. Burbey. - Rev.

p. cm. - (Regional aquifer system analysis-Great Basin, Nevada-Utah) (U.S. Geological Survey professional paper ; $1409-D)$

Burbey's name appears first on the earlier edition.

Includes bibliographical references (p. ).

Supt. of Docs. no.: I 19.16:1409-D

1. Groundwater flow-Great Basin. 2. Rock, Carbonate-Great Basin. I. Harrill, James R. II. Burbey, Thomas J. III. Title. IV. Series. V. Series: U.S. Geological Survey professional paper ; 1409-D.

GB1197.7.B87 1995

551.49'0979-dc20

For sale by U.S. Geological Survey, Information Services, Box 25286, Federal Center, Denver, CO 80225 


\section{FOREWORD}

\section{THE REGIONAL AQUIFER-SYSTEM ANALYSIS PROGRAM}

The Regional Aquifer-System Analysis (RASA) Program was started in 1978 following a congressional mandate to develop quantitative appraisals of the major ground-water systems of the United States. The RASA Program represents a systematic effort to study a number of the Nation's most important aquifer systems, which in aggregate underlie much of the country and which represent an important component of the Nation's total water supply. In general, the boundaries of these studies are identified by the hydrologic extent of each system and accordingly transcend the political subdivisions to which investigations have often arbitrarily been limited in the past. The broad objective for each study is to assemble geologic, hydrologic, and geochemical information, to analyze and develop an understanding of the system, and to develop predictive capabilities that will contribute to the effective management of the system. The use of computer simulation is an important element of the RASA studies, both to develop an understanding of the natural, undisturbed hydrologic system and the changes brought about in it by human activities, and to provide a means of predicting the regional effects of future pumping or other stresses.

The final interpretive results of the RASA Program are presented in a series of U.S. Geological Survey Professional Papers that describe the geology, hydrology, and geochemistry of each regional aquifer system. Each study within the RASA Program is assigned a single Professional Paper number, and where the volume of interpretive material warrants, separate topical chapters that consider the principal elements of the investigation may be published. The series of RASA interpretive reports begins with Professional Paper 1400 and thereafter will continue in numerical sequence as the interpretive products of subsequent studies become available.

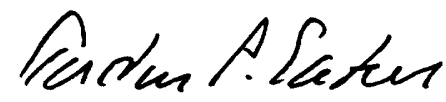

Gordon P. Eaton

Director 



\section{CONTENTS}

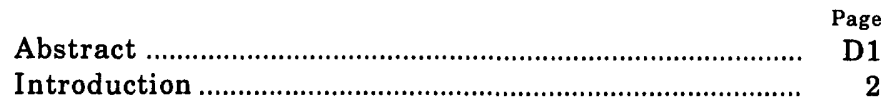

Purpose and scope

Previous investigations

Description of the carbonate-rock province

Physiography

Climate

Surface water

Acknowledgments

Ground water in the carbonate-rock province.

Hydrogeology.

Occurrence and movement of ground water

Conceptual evaluation of ground-water flow

General assumptions

Model development...

Application of finite-difference equations ...............

Model grid...

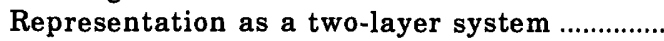

Boundary conditions

Modeling approach ...

Estimates of recharge...

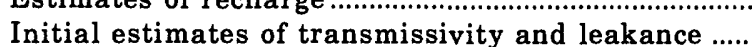

Model calibration...

Limits of calibration

Simulation results

Estimated transmissivities

Correlation of simulated ground-water flow to regional geologic features.

Distribution of flow into regions

Flow regions

Death Valley region

Inflow.

Outflow.

Description of subregions .

Big Smoky subregion

Clayton subregion.

Mesquite subregion
2

5

5

7

7

7

9

10

11

11

13

15

15

17

18

18

18

18

22

26

28

28

38

39

39

43

49

56

56

57

58

59

59

59

61
Flow region-Continued

Death Valley region-Continued

Description of subregions-Continued

Pahrump-Amargosa subregion ......................... D61

Ground-water flow to Furnace Creek .......... 62

Ground-water flow to Ash Meadows .............. 62

Colorado River region ...................................................... 64

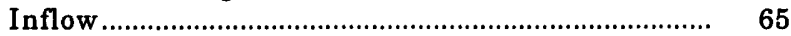

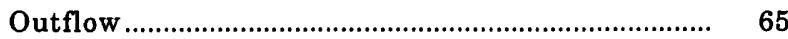

Description of subregions ........................................ 65

Penoyer subregion ............................................... 65

Las Vegas subregion .......................................... 67

Virgin River subregion ........................................ 69

White River subregion ......................................... 70

Bonneville region ....................................................... 73

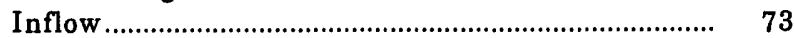

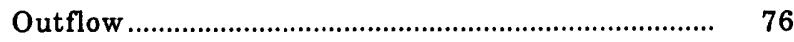

Description of subregions ....................................... 76

Escalante subregion ........................................... 76

Spring-Steptoe subregion …................................ 78

Ruby subregion .................................................. 79

Clover-Independence subregion ......................... 80

Utah Lake subregion ......................................... 81

Great Salt Lake Desert subregion ................... $\quad 82$

Railroad Valley region .................................................. 85

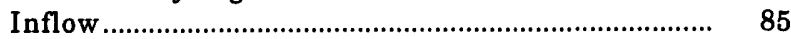

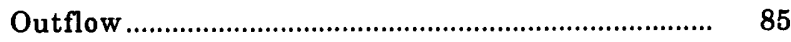

Description of ground-water flow ......................... 87

Upper Humboldt River region ...................................... $\quad 89$

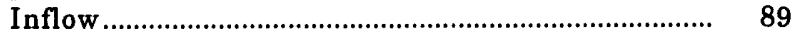

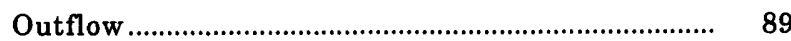

Description of subregions ........................................ 89

Diamond subregion .............................................. 89

Humboldt subregion ........................................ 92

Potential uses of model ...................................................... 93

Summary and conclusions ................................................ 93

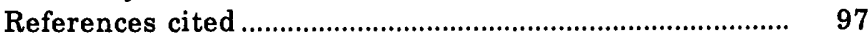

\section{ILLUSTRATIONS}

Figure 1. Map showing location and geographic features of study areas for Great Basin Regional Aquifer-System

Analysis (RASA) and carbonate-rock province....

2. Map showing hydrographic areas and location of Nevada Test Site

3. Graph showing population growth in study area between 1900 and 1990

4. Map showing distribution of average annual precipitation ...

5. Map showing distribution of rivers and lakes in and adjacent to study area for Great Basin Regional Aquifer-System Analysis....

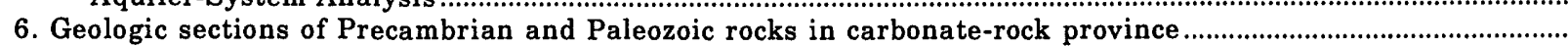

7. Map showing principal source areas for ground-water recharge, areas where ground water is consumed by evapotranspiration, and regional springs

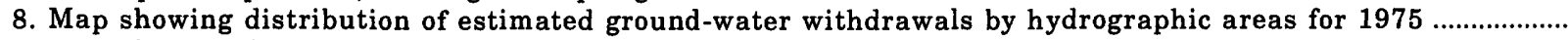

9. Map showing finite-difference grid network. 
Figure 10. Diagrams showing simulations of evapotranspiration as a function of water level.....

11-20. Maps showing:

11. Cells used to simulate spring discharge from lower model layer.

12. Wells tapping basin fill for which water-level data are available

13. Wells, test holes, and mine shafts tapping consolidated rocks for which water-level data are available.

14. Distribution of recharge assigned to cells in upper model layer, and simulated recharge from rivers and lakes through general-head boundaries

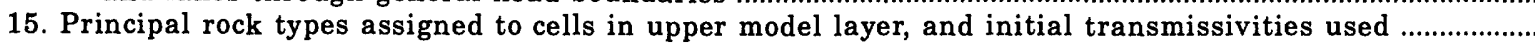

16. Estimated vertical leakance between cells in upper and lower model layers

17. Simulated evapotranspiration rates in cells in upper model layer, and simulated discharge from rivers, lakes, and Death Valley through general-head boundaries

18. Areas where ground water is consumed by evapotranspiration...

19. Simulated steady-state ground-water levels, upper and lower model layers

20. Estimated transmissivities, upper and lower model layers.....

21. Graphs showing frequency distributions of estimated transmissivities for cells in upper model layer on

basis of principal rock type, and for all cells in lower model layer

22-25. Maps showing:

22. Relation between selected geologic features and simulated ground-water levels, areas of evapotranspiration, and location of springs simulated in model

23. Distribution of shallow-flow regions delineated in upper model layer in relation to areas where ground water is consumed by evapotranspiration, simulated water levels in upper model layer, and outcrops of low-permeability rocks

24. Distribution of deep-flow regions and subregions delineated in lower model layer in relation to metamorphic core complexes, low-permeability rocks, and magnetic source bodies; and generalized directions of deep ground-water flow .

25. Distribution of high transmissivities in lower model layer in relation to springs simulated in model and to boundary of central corridor of thick carbonate rocks in south-central Nevada

26. Schematic diagrams showing conceptualization of ground-water flow from recharge areas in mountains to discharge areas on basin floors, same conceptualization of ground-water flow but represented in finite-difference computer model, and summary of water budget within area encompassed by a deep-flow region on basis of computer-model output

27-35. Maps showing:

27. Distribution of vertical flow between model layers .....

28. Areas of assigned recharge, simulated discharge from upper model layer, and simulated discharge from regional springs in Death Valley region

29. Simulated direction of ground-water flow for both upper and lower model layers in Death Valley region

30. Areas of assigned recharge, simulated discharge from upper model layer, and simulated discharge from regional springs in Colorado River region

31. Simulated direction of ground-water flow for both upper and lower model layers in Colorado River region

32. Areas of assigned recharge, simulated discharge from upper model layer, and simulated discharge from regional springs in Bonneville region.

33. Simulated direction of ground-water flow for both upper and lower model layers in Bonneville region ...

34. Areas of assigned recharge, simulated discharge from upper model layer, simulated discharge from regional springs, and simulated direction of ground-water flow for both upper and lower model layers in Railroad Valley region

35. Areas of assigned recharge, simulated discharge from upper model layer, simulated discharge from regional springs, and simulated direction of ground-water flow for both upper and lower model layers in upper Humboldt River region

\section{TABLES}

TABLE 1. Estimated discharge of regional springs compared with simulated discharge following model calibration........

2. Selected statistics of estimated transmissivities in both model layers

3. Summary of estimated transmissivities for model cells corresponding to selected rock types in both model layers

4-9. Simulated ground-water flow budgets for:

4. Death Valley region....

5. Colorado River region

6. Bonneville region

7. Railroad Valley region

8. Upper Humboldt River region

9. Five deep-flow regions of modeled area 


\section{CONVERSION FACTORS AND VERTICAL DATUM}

\begin{tabular}{rll}
\hline Multiply & \multicolumn{1}{c}{ By } & \multicolumn{1}{c}{ To obtain } \\
\hline acre-foot (acre-ft) & 0.001233 & cubic hectometer \\
acre-foot per year (acre-ft/yr) & 0.001233 & cubic hectometer per year \\
cubic foot per second $\left(\mathrm{ft}^{3} / \mathrm{s}\right)$ & 0.02832 & cubic meter per second \\
foot $(\mathrm{ft})$ & 0.3048 & meter \\
foot per mile $(\mathrm{ft} / \mathrm{mi})$ & 0.1894 & meter per kilometer \\
gallon per day per foot $(\mathrm{gal} / \mathrm{d} / \mathrm{ft})$ & 0.01242 & square meter per day \\
inch $(\mathrm{in})$. & 25.40 & millimeter \\
inch per year $(\mathrm{in} / \mathrm{yr})$ & 25.40 & millimeter per year \\
mile $(\mathrm{mi})$ & 1.609 & kilometer \\
foot squared per second $\left(\mathrm{ft}^{2} / \mathrm{s}\right)$ & 0.0929 & meter squared per second \\
foot squared per day $\left(\mathrm{ft}^{2} / \mathrm{d}\right)$ & 0.0929 & meter squared per day \\
square mile $\left(\mathrm{mi}^{2}\right)$ & 2.590 & square kilometer \\
\hline
\end{tabular}

Temperature: Degrees Fahrenheit $\left({ }^{\circ} \mathrm{F}\right)$ may be converted to degrees Celsius $\left({ }^{\circ} \mathrm{C}\right)$ by using the formula ${ }^{\circ} \mathrm{C}=0.5556\left({ }^{\circ} \mathrm{F}-32\right)$.

Sea level: In this report, "sea level" refers to the National Geodetic Vertical Datum of 1929-a geodetic datum derived from a general adjustment of the first-order level nets of the United States and Canada, formerly called Sea Level Datum of 1929. 



\title{
CONCEPTUAL EVALUATION OF REGIONAL GROUND-WATER FLOW IN THE CARBONATE-ROGK PROVINGE OF THE GREAT BASIN, NEVADA, UTAH, AND ADJACENT STATES
}

\author{
By David E. Prudic, James R. Harrill, and Thomas J. Burbey
}

\begin{abstract}
The carbonate-rock province of the Great Basin, mainly in eastern Nevada and western Utah, is characterized by thick sequences of carbonate rocks of Paleozoic age. These rocks overlie clastic and crystalline rocks of Cambrian and Precambrian age, respectively. Since the carbonate rocks were deposited, structural compression and extension, intrusive and volcanic episodes, and erosion have greatly modified their distribution and thickness, and a variety of younger rocks and deposits have been emplaced within and above them. The most notable present-day physiographic features in the area are associated with normal faults caused by tensional forces during Tertiary time. The faulting has formed the north- to northeast-trending mountain ranges and adjacent sedimentary basins that characterize the terrane. The 100,000 -square-mile study area, with its abundant carbonate rocks, is referred to in this report as the carbonate-rock province of the Great Basin.

Regional ground-water flow in the province has been studied as part of the Great Basin Regional Aquifer-System Analysis. The flow system is conceptualized as having (1) a relatively shallow component, moving primarily from mountain ranges to basin fill beneath adjacent valley floors, which is superimposed upon (2) a deeper component, moving primarily through carbonate rocks. A computer model has been developed to simulate and thereby evaluate the regional flow. Two model layers are used to simulate the two components. The layers are divided into cells with dimensions of 5 miles by 7.5 miles, elongate in a north-northeastward direction. The maximum depth of flow in the province is unknown, but freshwater has been detected at depths as great as 10,000 feet.

The conceptualization and simulation of regional groundwater flow includes several simplifying assumptions: Flow through fractures and solution openings in consolidated rocks is approximately equivalent to flow through a porous medium; Darcy's Law is applicable from a regional perspective; steadystate conditions exist, in which estimates of present-day recharge equal natural discharge prior to ground-water withdrawals; transmissivity is heterogeneous over the region but is homogeneous and isotropic in each 37.5-square-mile model cell; recharge is from precipitation in the mountain ranges and percolation from rivers and lakes; and discharge is by evapotranspiration, seepage to rivers and lakes, and flow from regional springs. Although the assumptions are probably valid for parts of the province, the validity of each assumption is unknown for the province as a whole. Therefore,
\end{abstract}

the simulation results do not completely replicate actual ground-water flow throughout the province; rather, the intent of the simulations is to provide a conceptual evaluation of regional ground-water flow.

The model was calibrated by adjusting the transmissivities of cells in both model layers and the vertical leakance of cells between layers during repeated simulations. Calibration proceeded until simulated water levels and simulated discharge as evapotranspiration and regional-spring flow generally agreed with available water levels, the mapped distribution and estimated quantity of evapotranspiration, and the estimated flow at regional springs. Because of (1) the scarcity of available water-level data, particularly for the carbonate-rock aquifers, (2) the uncertainty in the extent and thickness of the carbonate-rock aquifers, and (3) the uncertainty in the estimates of ground-water recharge and evapotranspiration, other distributions and estimates of transmissivities and vertical leakances than those calibrated may also adequately simulate water levels and discharge in the province. Nonetheless, several inferences can be made regarding ground-water flow in the province from the model results.

Transmissivities in the upper model layer are generally greater in cells corresponding to basin fill and carbonate rocks, and are less in cells corresponding to other consolidated rocks (clastic, metamorphic, igneous, and volcanic). In the lower layer, transmissivities are greatest near regional springs and in the vicinity of basins where ground-water discharge is considerably more than the estimated recharge from the immediately surrounding drainage area.

Simulated inflow to the modeled area is about $1.5 \mathrm{mil}$ lion acre-feet per year, which is only 3 percent of the estimated total precipitation. This inflow does not include recharge that discharges locally (that is, within the same 37.5-squaremile model cell). Most ground-water flow is simulated in the upper model layer; it moves from mountainous recharge areas to adjacent valley lowlands where it discharges by evapotranspiration. A total of 45 shallow-flow regions is identified on the basis of horizontal flow between model cells.

In the lower layer, simulated flow is 428,000 acre-feet per year, or only 28 percent of the total inflow. About half of the flow is discharged to regional springs that represent the discharge of deep flow through carbonate rocks. Seventeen deep-flow subregions are identified on the basis of horizontal flow between model cells. These subregions are further grouped into five deep-flow regions on the basis of water-level patterns. Simulated flow in the lower layer is generally southward and northward from a large, topographically high area 
in east-central Nevada and southwestern Utah. Southward flow is toward Death Valley and the Colorado and Virgin Rivers; northward flow is toward the Great Salt Lake Desert and the upper Humboldt River. However, only small quantities of deep flow are simulated as discharge to the Death Valley playa, the Colorado and Virgin Rivers, the Humboldt River, and the Great Salt Lake Desert. Instead, most of the flow is discharged upgradient from these sinks. Within the topographically high area of east-central Nevada, some deep ground water flows to a land-surface depression in Railroad Valley.

In conclusion, most ground-water flow is relatively shallow, moving from recharge areas in the mountain ranges to discharge areas in adjacent valleys. Directions of shallow groundwater flow do not correspond everywhere to directions of deep flow. Deep ground-water flow mostly discharges at regional springs or in areas of evapotranspiration upgradient from the terminal sinks (the Great Salt Lake, the Great Salt Lake Desert, the Railroad Valley and Death Valley playas, and the Colorado, Virgin, and Humboldt Rivers). Interbasin movement of ground water to the larger regional springs is through permeable carbonate rocks in areas where the rocks are thick and continuous; elsewhere, consolidated rocks beneath the valleys and surrounding mountains are not highly transmissive, suggesting that not all carbonate rocks are highly permeable or that not all valleys and surrounding mountains are underlain by carbonate rocks.

\section{INTRODUCTION}

Ground-water flow within an area dominated by basin-fill and carbonate-rock aquifers was studied as part of the Great Basin Regional AquiferSystem Analysis (RASA). The Great Basin RASA project began in 1980 as a component of a national program designed to systematically study large aquifer systems that constitute a major part of the Nation's water supply (Harrill and others, 1983 , p. 2). Results of the Great Basin RASA project, in addition to those described in this report, include detailed studies of ground-water flow in selected basins and analyses of regional hydrogeology and geochemistry.

The area of the Great Basin RASA project is about $140,000 \mathrm{mi}^{2}$ and includes most of Nevada, westernmost Utah, and small parts of California, Oregon, Idaho, and Arizona (fig. 1). The project area is characterized by northeast-trending mountains and adjoining basins that are partly filled with sediments derived from the mountains. Ground-water flow in this area is typically from recharge areas in and adjacent to the mountains to discharge areas in the valley lowlands. Carbonate rocks, deposited in a shallow sea during the Paleozoic Era, underlie large areas in the eastern two-thirds of the Great Basin. These rocks can be highly permeable where thick sequences are present, thereby providing conduits for the interbasin movement of ground water (Eakin, 1966; Mifflin, 1968; Winograd and Thordarson, 1975; Gates, 1984, 1987; Dettinger, 1989).

Ground water is pumped primarily from unconsolidated deposits that partly fill each of the 240 hydrographic areas (Harrill and others, 1983, p. 5), most of which are topographically closed or nearly closed basins (fig. 2). The hydrographic areas usually contain a ground-water reservoir in the basin fill and include the drainage area of adjacent mountains. These hydrographic areas are used by State and local agencies for planning and management of water resources.

The general area underlain by carbonate rocks is defined in this report as the carbonate-rock province of the Great Basin and is bounded on the east, south, and north by boundaries of the Great Basin RASA project (Harrill and others, 1983; fig. 1). These boundaries include the Wasatch Range and the Colorado Plateau to the east, the Snake River drainage divide to the north, and the predominantly Precambrian rock exposures in the mountains to the south. The southern boundary also includes hydrologic boundaries of the Virgin and Colorado Rivers and Death Valley (fig. 1). The western boundary is generally the easternmost extent of transitional-assemblage sedimentary rocks of Paleozoic age (Plume and Carlton, 1988, fig. 2). The transitional-assemblage rocks are composed of limestone, shale, siltstone, and quartzite (Stewart, 1980, p. 20). These rocks separate coeval carbonate rocks deposited on a broad shelf to the east from marine sedimentary rocks of shale, chert, and quartzite and volcanic rocks deposited in a deep-water basin to the west. The province encompasses an area of about $100,000 \mathrm{mi}^{2}$.

As of 1990 , population in the province was more than 2.3 million (U.S. Bureau of the Census, 1991a, 1991b). Most of these people live along the eastern border where perennial streams flow from the Wasatch Range into the adjacent valleys, or near other sources of surface water such as the Humboldt River and Lake Mead (fig. 1). Almost three-quarters of a million people live in the Las Vegas metropolitan area, and more than a million people live in the vicinity of Salt Lake City. Population densities averaged over the land area in each county range from 2 to 980 people per square mile in Utah and from less than one person to 94 people per square mile in Nevada.

Population in the province at the turn of the last century was less than 300,000 (fig. 3), and most of the people lived in the vicinity of Salt 


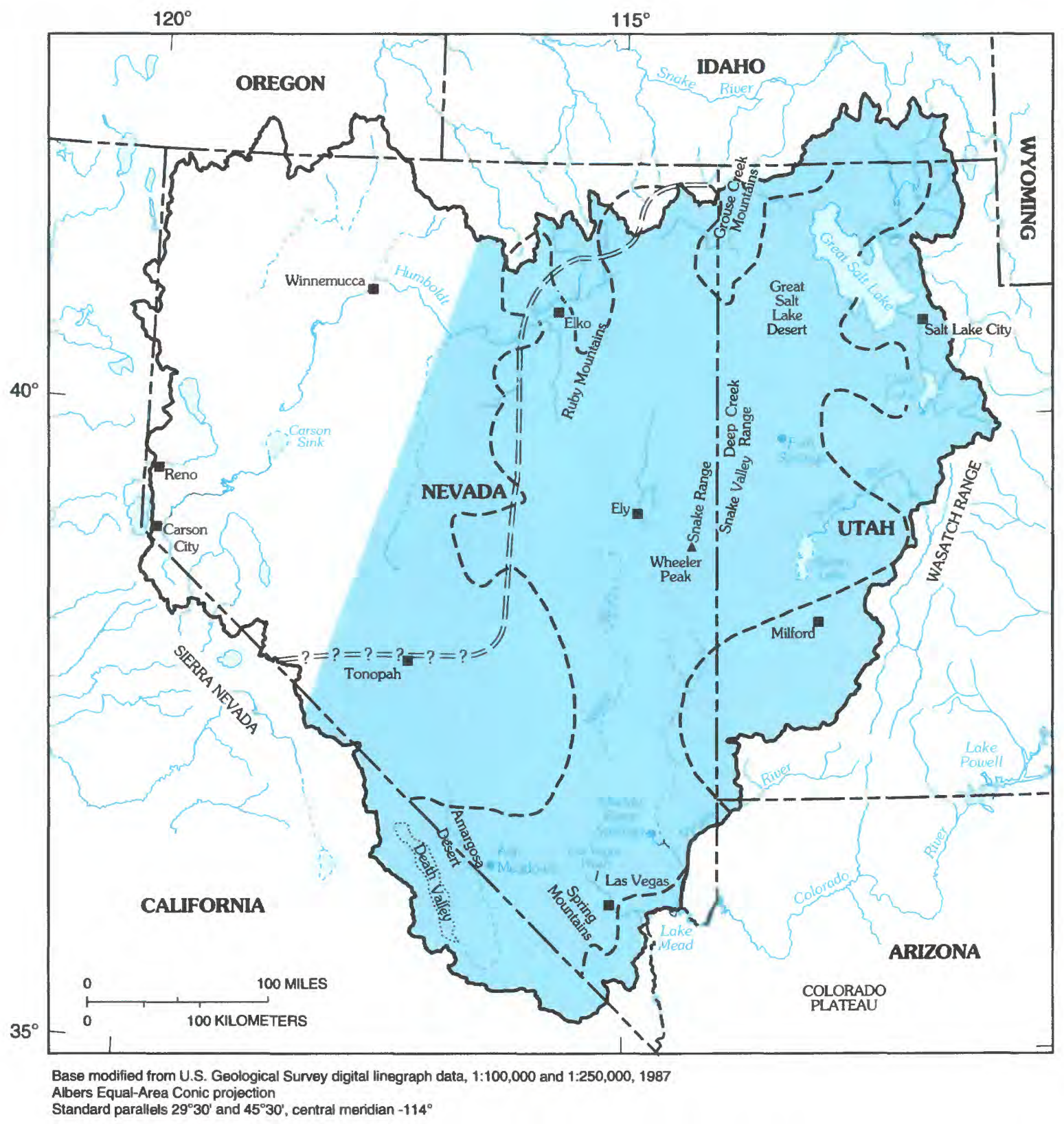

\section{EXPLANATION}

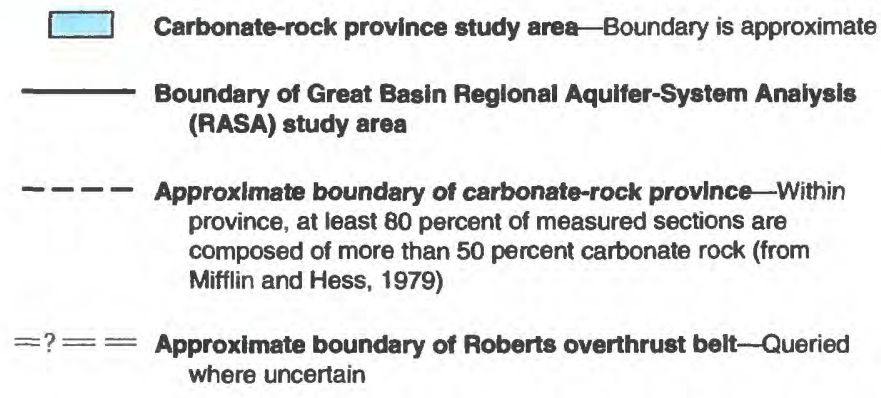

Note: Lakes and rivers dashed where ephemeral

Figure 1.-Location and geographic features of study areas for Great Basin Regiona Aquifer-System Analysis (RASA) and carbonate-rock province. 
Lake City where surface-water supplies are plentiful. The number of people living in the province increased slowly until after World War II. Since World War II, the population has increased fivefold. The marked increase in the number of people living in Nevada (fig. 3) is largely in the Las Vegas area, where the population increased from about 16,000 people in 1940 to more than

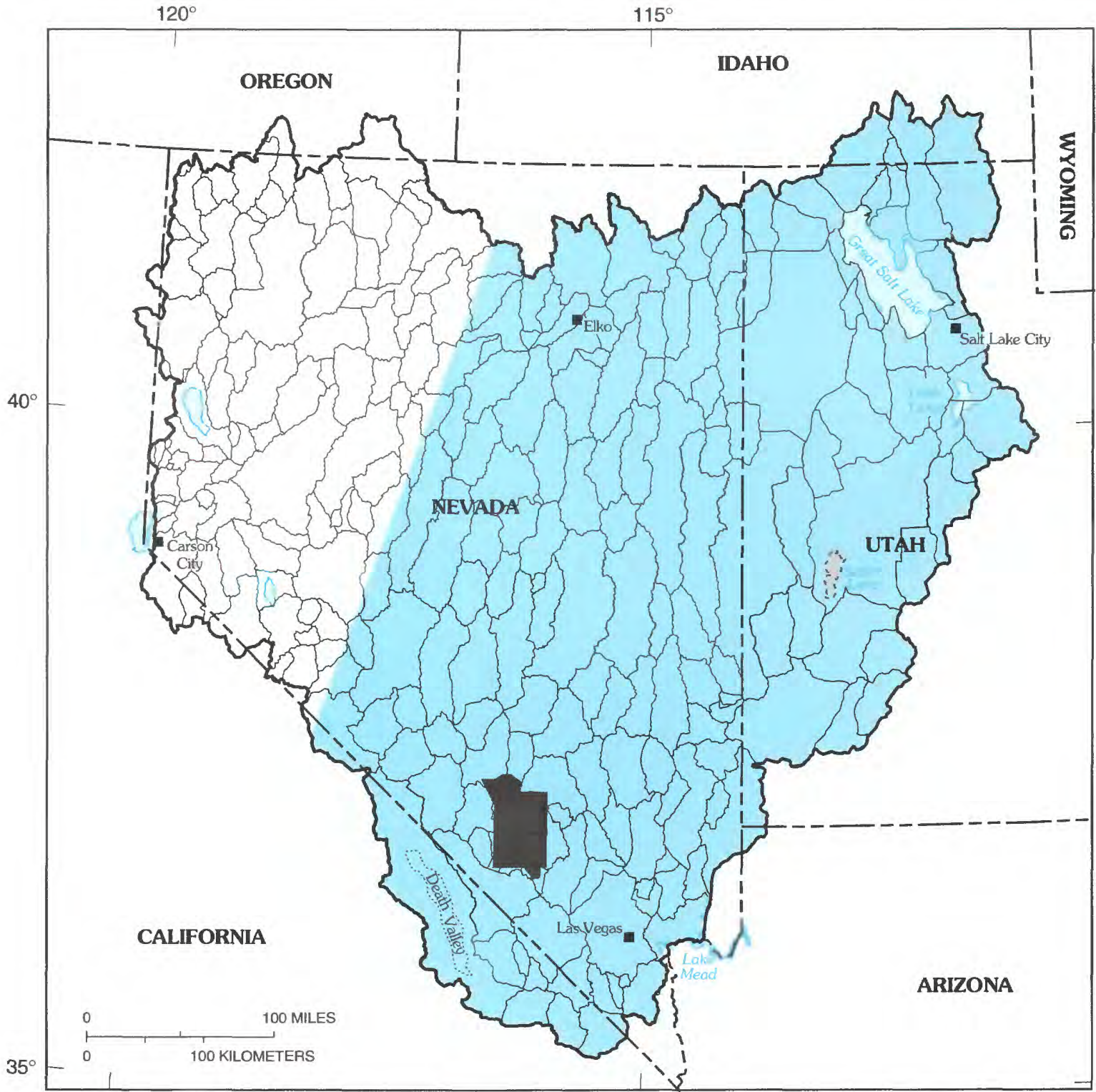

Base modified from U.S. Geological Survey digital linegraph data, 1:100,000 and 1:250,000, 1987 Albers Equal-Area Conic projection

Standard parallels $29^{\circ} 30^{\prime}$ and $45^{\circ} 30^{\prime}$, central meridian $-114^{\circ}$

\section{EXPLANATION}

Carbonate-rock province study area-Boundary is approximate

Nevada Test Site

Boundary of Great Basin Regional Aquifer-System Analysis (RASA) study area

Boundary of hydrographic area or subarea

FIGURE 2.-Hydrographic areas and location of Nevada Test Site. Hydrographic-area boundaries from Harrill and others (1988). 
770,000 in 1990 . As the number of people in the province increases and surface-water supplies become less available, additional sources of water will be needed. One such source that has been proposed (Hess and Mifflin, 1978) is the water stored in the carbonate rocks beneath much of western Utah and eastern Nevada.

In most other RASA studies, enough information exists for comprehensive model simulations and evaluations of ground-water flow in regional aquifer systems. Although numerous wells have been drilled within the carbonate-rock province, most have been drilled into unconsolidated deposits in the valleys and usually to shallow depths, except at the Nevada Test Site. Thus, little is known about the deeper and more regional ground-water flow in the carbonate rocks. However, because of the greatly increased demand for water and because of the potential for contamination of ground water from underground testing of nuclear weapons at the Nevada Test Site (fig. 2) and from the possible storage and disposal of nuclear and hazardous wastes, an improved understanding of ground-water flow in the province is needed.

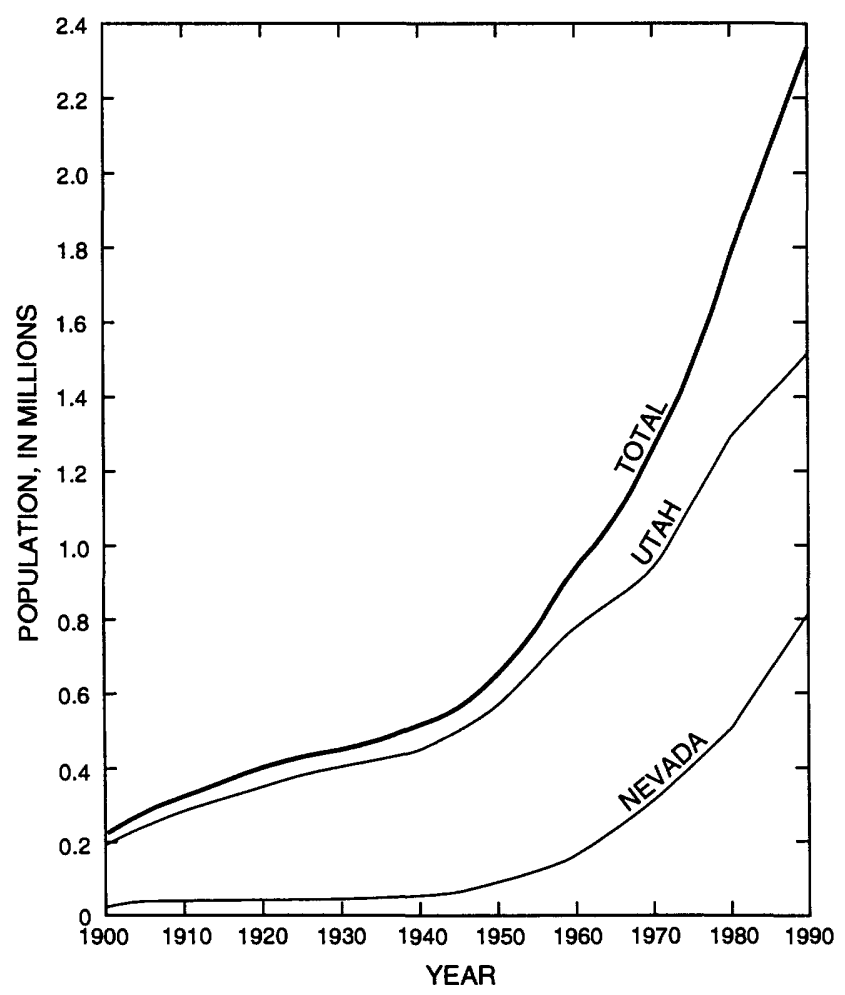

Figure 3.-Population growth in study area between 1900 and 1990. Data from U.S. Bureau of Census $(1913,1921,1952$, $1983,1991 \mathrm{a}, \mathrm{b})$.

\section{PURPOSE AND SCOPE}

The purpose of this report is to present a conceptual evaluation of ground-water flow in the carbonate-rock province, mainly in Nevada and Utah. The evaluation is based on simulation results using the three-dimensional ground-water flow model of McDonald and Harbaugh (1988). The basic conceptual model for the province includes relatively shallow flow from recharge areas in the mountains to discharge areas in the adjacent valley lowlands, superimposed over deeper, more regional flow through carbonate rocks. The concept is based on theoretical analyses of regional flow by Freeze and Witherspoon (1967, p. 623-634) where, in regions of hummocky terrain, numerous relatively shallow flow systems are superimposed over fewer deeper flow systems. Results of the model analysis include: transmissivity distributions, identification of shallow and deep flow systems, and comparisons of simulated flow and discharge to estimates presented in previous reports.

The original version of this report was published in January 1991 as a U.S. Geological Survey interim Open-File Report and in September 1991 as a U.S. Geological Survey Professional Paper. In November 1991, an error that resulted from an inadvertent coding transposition of the cell-dimension variables DELR and DELC (McDonald and Harbaugh, 1988, chap. 5, p. 8) was discovered. This error produced an unintended regional anisotropy in the model transmissivities (Stillwater and others, 1992). As a result, the model grid cell dimensions have been corrected and the model recalibrated. David E. Prudic did the recalibration and, along with James R. Harrill, has revised the report to reflect changes resulting therefrom. In addition, Donald H. Schaefer and James R. Harrill assisted in checking information used in the model.

\section{PREVIOUS INVESTIGATIONS}

Surveys of geologic features in the Great Basin began in the late 1860's under the leadership of Clarence King, J.W. Powell, G.K. Gilbert, A.R. Morvine, and E.E. Howell. Nolan (1943) summarized available geologic information pertaining to the entire Great Basin. Between 1938 and the late 1970's, numerous geologic investigations were completed in the Great Basin region. The results of all these studies and studies before 1938 
are summarized on a map of Nevada by Stewart and Carlson (1978), a publication about Nevada by Stewart (1980), and a map of Utah by Hintze (1973). Since 1980, numerous articles have been published that pertain generally to metamorphic core complexes, geophysics, and geologic structure. The hydrogeologic framework of the Great Basin has been described by Plume (1995) as another part of the Great Basin RASA project.

Ground-water investigations within the carbonate-rock province began in the early 1900's. Mendenhall (1909, p. 13) suggested that many of the desert springs in southern Nevada are not dependent on rainfall in the area immediately surrounding the springs but that their source is from distant mountains. Carpenter (1915, p. 18) noted that rocks exposed in the mountains in southeastern Nevada generally act to close the adjacent valleys by making the sides and bottoms of the valleys practically impervious. He did, however, state that several topographically closed valleys higher in altitude than adjacent valleys lose water through fissures in the rocks because water levels in the higher valleys are far below land surface. Meinzer (1917, p. 150) reported that water from a valley near Tonopah, Nev. (fig. 1), leaks through a mountain range into an adjacent valley. These are some of the earliest reports that suggest the possibility of interbasin flow of ground water within the carbonate-rock province.

Few additional ground-water investigations were done until after World War II, when several studies of selected basins commenced. These studies generally focused on recharge and discharge of ground water in individual basins. In the early 1960's, the State of Nevada and the U.S. Geological Survey began systematic reconnaissance studies of all unstudied basins in Nevada to determine potential ground-water supplies. A similar series of investigations began in Utah in 1964. The results of these investigations have been published by the Nevada Department of Conservation and Natural Resources and the Utah Department of Natural Resources, and most are summarized in Eakin and others (1976). These reports provide the basic estimates of recharge and discharge used in this report.

Detailed discussion of interbasin flow also began in the 1960's. Hunt and Robinson (1960) discussed the possibility of interbasin flow into the Death Valley (fig. 1) area on the basis of chemical analysis of water samples from springs and wells. Loeltz (1960) discussed the source of water issuing from springs at Ash Meadows in the
Amargosa Desert near Death Valley (fig. 1). Winograd (1962) discussed interbasin movement of ground water at the Nevada Test Site. Winograd (1963) also summarized ground-water flow between Las Vegas Valley and the Amargosa Desert and presented evidence for fault compartmentalization of the aquifers in the region. Eakin and Moore (1964) presented information about the uniformity of discharge at Muddy River Springs in southeastern Nevada (fig. 1) and related it to interbasin movement of ground water. Winograd and Eakin (1965) and Eakin and Winograd (1965) presented evidence and some economic implications of interbasin flow of ground water in south-central Nevada. Hood and Rush (1965) discussed the possibility of interbasin flow of water to and from Snake Valley in western Utah (fig. 1). Eakin (1966) presented information that described interbasin flow in an area in southeastern Nevada that he named the White River area. Shortly afterward, Mifflin (1968) delineated ground-water basins for all Nevada and concluded that interbasin flow of ground water occurs wherever the consolidated rocks in the mountains and beneath the valleys are permeable or wherever the basins are connected by unconsolidated deposits. The area of interbasin flow through permeable consolidated rocks is primarily within the carbonate-rock province. Mifflin and Hess (1979) discussed regional carbonate flow systems in Nevada. Gates and Kruer (1981) discussed regional flow in west-central Utah, and Gates $(1984,1987)$ discussed regional flow in northwestern Utah and adjacent parts of Idaho and Nevada.

The U.S. Geological Survey began a study in 1981 to evaluate potential hydrogeologic environments for isolation of high-level radioactive waste in the Basin and Range physiographic province of the southwestern United States. The study includes a much larger area than is described in this report. Bedinger and others $(1989,1990)$ characterized the geology and hydrology of the Death Valley region and the Bonneville region; both areas are included in this study.

The most detailed information regarding ground-water flow in carbonate rocks is at the Nevada Test Site (fig. 2). Detailed studies began in 1957 and included the drilling of several deep test holes into carbonate rocks beneath the unconsolidated and volcanic deposits in the vicinity of the Test Site during 1962-64. Numerous reports have been written about the area. Most of the work from 1957-64 is summarized by Winograd and Thordarson (1975), which is the 
most detailed description of ground-water flow through carbonate rocks in the province. Some of the more recent reports that pertain to groundwater flow near the Test Site include Winograd and Pearson (1976), Waddell (1982), Claassen (1983), and Waddell and others (1984).

In addition to test wells drilled in the vicinity of the Nevada Test Site, many wells have been drilled in the province for other purposes, including several into carbonate rocks as part of the U.S. Air Force MX missile-siting program in the Great Basin. Selected hydrologic data collected for the Air Force by the contractor, ERTEC, Inc. (or Earth Technology, Inc., formerly FUGRO) are presented by Bunch and Harrill (1984). Geochemical studies as a part of the Great Basin RASA project and more recent studies of the carbonate-rock aquifers in eastern and southern Nevada provide additional evidence of interbasin flow (Welch and Thomas, 1984; Thomas, 1988; Dettinger, 1989; Kirk and Campana, 1990). Also, regional ground-water flow in the vicinity of Fish Springs (fig. 1) in western Utah was analyzed using a computer model as part of the Great Basin RASA project (Carlton, 1985).

\section{DESCRIPTION OF THE CARBONATE-ROCK PROVINCE}

\section{PHYSIOGRAPHY}

The carbonate-rock province of the Great Basin is characterized by a series of generally north- to northeast-trending mountain ranges composed predominantly of carbonate rocks of Paleozoic age. The intervening valleys are partly filled with detritus from the mountains. Both the mountain ranges and the valleys are generally 5 to $15 \mathrm{mi}$ wide and are typically elongate, commonly 40 to $80 \mathrm{mi}$ long. The mountain ranges rise from $1,000 \mathrm{ft}$ to more than $7,000 \mathrm{ft}$ above the adjacent valleys.

Altitudes of valley floors in the southern part of the province range from below sea level to 3,000 $\mathrm{ft}$ above sea level. Death Valley (fig. 1) is the lowest point in the province, as well as the $\mathrm{Na}$ tion, and at its lowest point is $282 \mathrm{ft}$ below sea level. Altitudes of valley floors in the province exceed $6,000 \mathrm{ft}$ in north-central Nevada, whereas valley floors in western Utah are between 4,000 and $5,000 \mathrm{ft}$. Several of the mountain ranges in the province exceed $10,000 \mathrm{ft}$ in altitude. The highest mountains in the southern part are the Spring Mountains west of Las Vegas with altitudes ex- ceeding $11,000 \mathrm{ft}$. The Ruby Mountains in northern Nevada exceed $12,000 \mathrm{ft}$, but the highest point in the province, at $13,063 \mathrm{ft}$, is Wheeler Peak in the Snake Range (fig. 1), which is in Nevada near the border with Utah. The Wasatch Range in Utah, which has several peaks that exceed $11,000 \mathrm{ft}$, forms the eastern boundary of the study area.

\section{CLIMATE}

Climate in the province is highly variable, ranging from arid to semiarid on most of the valley floors to humid alpine in the higher mountains. Average annual precipitation on the valley floors ranges from less than $3 \mathrm{in}$. in the Amargosa Desert and Death Valley to about 16 in. in some of the higher valleys in north-central Nevada and northern Utah. Average annual precipitation in the mountains ranges from about 8 in. in some of the lower southern mountains to more than 60 in. in some parts of the highest mountains. Estimated annual precipitation in the province is shown in figure 4. Approximately 54 million acre$\mathrm{ft}$ of precipitation annually falls in the province. The regionally averaged annual precipitation for the province is less than 10 in., making it one of the drier regions in the United States.

Houghton (1967) reported three sources of precipitation in the province: (1) moisture from the Pacific Ocean, (2) moisture from the Gulf of Mexico, and (3) moisture evaporated within the Great Basin. Much of the precipitation falls between October and May from storm fronts that begin in the subpolar North Pacific Ocean. Generally, these storm fronts are much less frequent in the southern part than in the northern part of the province (north of latitude $40^{\circ}$ ). However, unusually heavy quantities of precipitation from Pacific storms can fall in the southern part of the province (south of latitude $40^{\circ}$ ) when secondary lows develop south of the subpolar fronts and move inland.

Houghton (1967) also suggested that precipitation from moisture that moves inland from the Gulf of Mexico happens only during the summer, when southeasterly winds carry moist tropical air into the southern and eastern parts of the province and produce scattered convective showers. More recent information (Brenner, 1974) suggests that these convective showers are from moisture which moves northward from the Gulf of California along the Colorado River and that no precipitation is derived from the Gulf of Mexico. In 


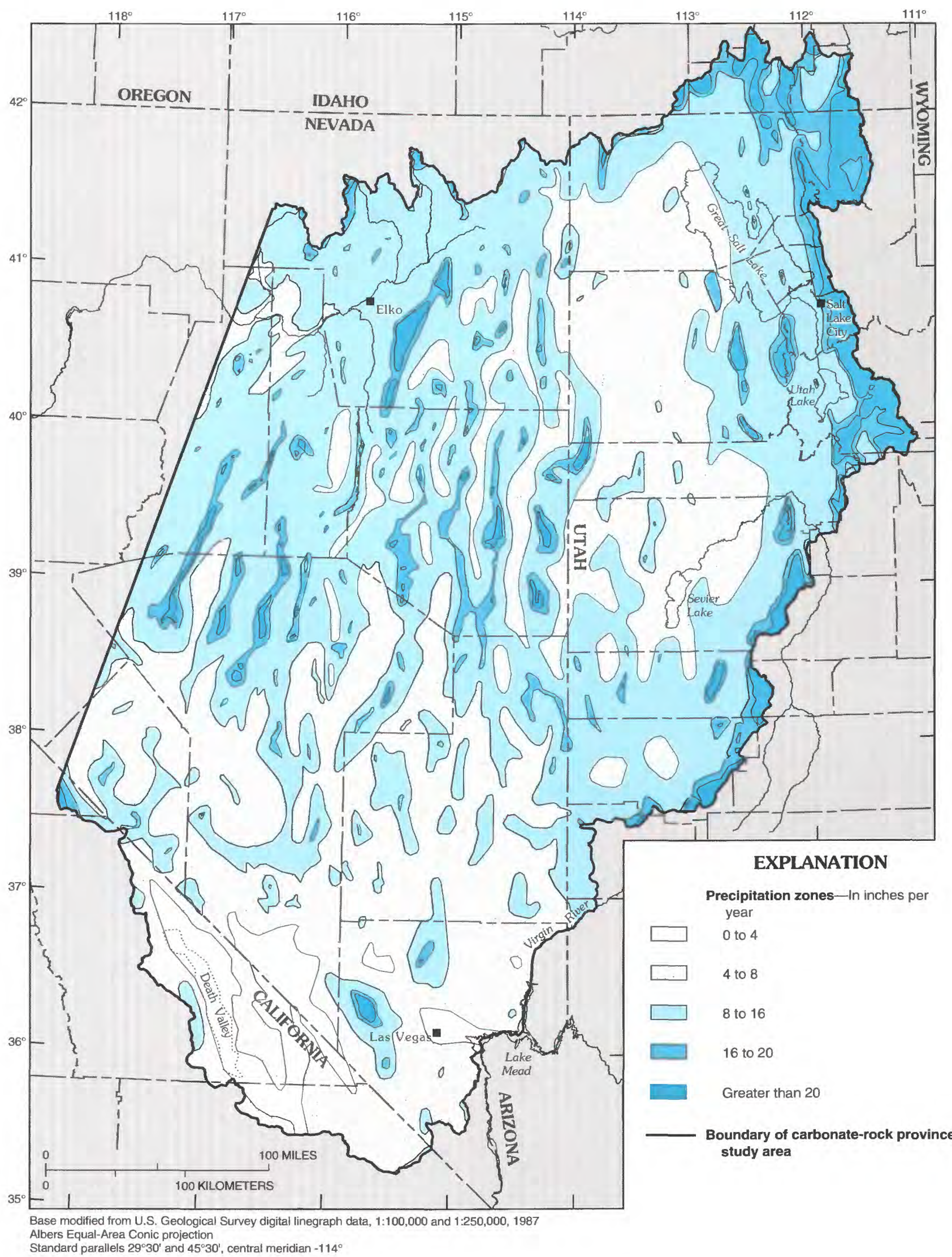


addition, the source of most of the precipitation in the southern part of the province is from tropical storms that originate in the Pacific Ocean near Central America. These storms generally move out to sea but occasionally move inland near northern Mexico and southern California and dissipate over Arizona, southern Nevada, and Utah (K.P. Smith, University of Arizona, Tucson, oral commun., 1986). The storms are most common from late August to November but do not necessarily occur every year.

Precipitation from water evaporated over the Great Basin is associated with surface cyclones (Houghton, 1967, p. 6) that usually develop in the spring and fall. The storms are most frequent from March until mid-June and gradually shift from south to north but generally provide little moisture.

Average annual temperature ranges from about $30^{\circ} \mathrm{F}$ in some high northern valleys to about $60^{\circ} \mathrm{F}$ in the extreme southern valleys (Eakin and others, 1976, p. 3). Temperatures are subject to large daily and seasonal fluctuations. Daily fluctuations in most valleys exceed $30^{\circ} \mathrm{F}$, and $40^{\circ} \mathrm{F}$ changes are not uncommon. Large variations in temperature are observed within short distances due to the topography. Summer temperatures can exceed $100^{\circ} \mathrm{F}$, particularly in the south, where the maximum summer temperatures can reach $120^{\circ} \mathrm{F}$. Minimum temperatures can drop below $0^{\circ} \mathrm{F}$ in the northern part of the province.

Average annual humidity ranges from about 30 to 40 percent over most of the region and is about 20 percent in the extreme south. Low humidity, abundant sunshine, and light to moderate winds result in rapid evaporation. Average annual lake evaporation ranges from about 40 in. in the north to more than 70 in. in the extreme south (Kohler and others, 1959, pl. 2).

\section{SURFACE WATER}

The Great Salt Lake, in northwestern Utah, has the largest area of any body of surface water in the province (fig. 5). The size of the lake

FIGURE 4,-Distribution of average annual precipitation. Precipitation zones for Nevada from Hardman (1965); zones for Utah and Idaho from U.S. Weather Bureau (1963 and 1965, respectively); zones for California from Rantz (1972). Precipitation zones near Death Valley and Amargosa Desert modified from those of Winograd and Thordarson (1975, p. 8). varies considerably depending on the altitude of the water surface in the lake, which has fluctuated about $20 \mathrm{ft}$ during 1847-1982 (Arnow, 1984, p. 1). The average size of the lake during this period has been $1,700 \mathrm{mi}^{2}$, and the average lake volume has been 16 million acre-ft. The lake is unique in North America in that it is considerably saltier than the oceans.

Most of the water that enters the Great Salt Lake is surface runoff that originates as precipitation in the nearby Wasatch Range. The major rivers that feed the lake are the Bear, Weber, and Jordan. Surface inflow to the lake averaged $\mathbf{1 . 9}$ million acre-ft/yr during 1931-76, whereas groundwater inflow is estimated at 75,000 acre-ft/yr (Arnow, 1984, p. 15, 16).

Lake Mead borders the south end of the province and was formed after Hoover Dam was built on the Colorado River near Las Vegas in the 1930's. The lake supplies water to parts of Nevada, California, and Arizona. Tributary streams that discharge into Lake Mead, and that begin within or border the province, include (1) the Virgin River, which borders the southeastern edge of the province, (2) the Muddy River, which begins at the Muddy River Springs about $50 \mathrm{mi}$ northwest of Lake Mead, and (3) Las Vegas Wash, which discharges water from Las Vegas Valley (fig. 5).

In addition to the rivers and streams that drain into the Great Salt Lake and Lake Mead, a few other river systems either begin within the province or enter it from bordering mountains and discharge into terminal sinks. The Sevier River drains several high-altitude basins along the western margin of the Colorado Plateau and discharges into ephemeral Sevier Lake (fig. 5). Its average annual flow near where the river enters the province is about 190,000 acre-ft for a 73-year period, 1913-85 (ReMillard and others, 1986, p. 320). The Humboldt River begins in northeastern Nevada, flows westward, and exits the province near Palisade (fig. 5) on its way to the Humboldt and Carson Sinks. The average annual flow near Palisade is about 290,000 acre-ft for a 77-year period, 1902-06 and 1911-84 (Frisbie and others, 1985 , p. 134). The Amargosa River, which is ephemeral over most of its course, begins in southwestern Nevada (fig. 5) and flows south, west, and then north on its way to Death Valley, which is the terminus for both surface- and ground-water flow in southwestern Nevada and southeastern California.

Streams are considerably less common within the interior of the province, however, than over 
the rest of the Great Basin (fig. 5), suggesting that the carbonate rocks exposed in the mountains allow for more recharge into and through the mountain blocks than do other types of rocks.

\section{ACKNOWLEDGMENTS}

We give special thanks to Catherine KraegerRovey of Water \& Environmental Systems Tech-

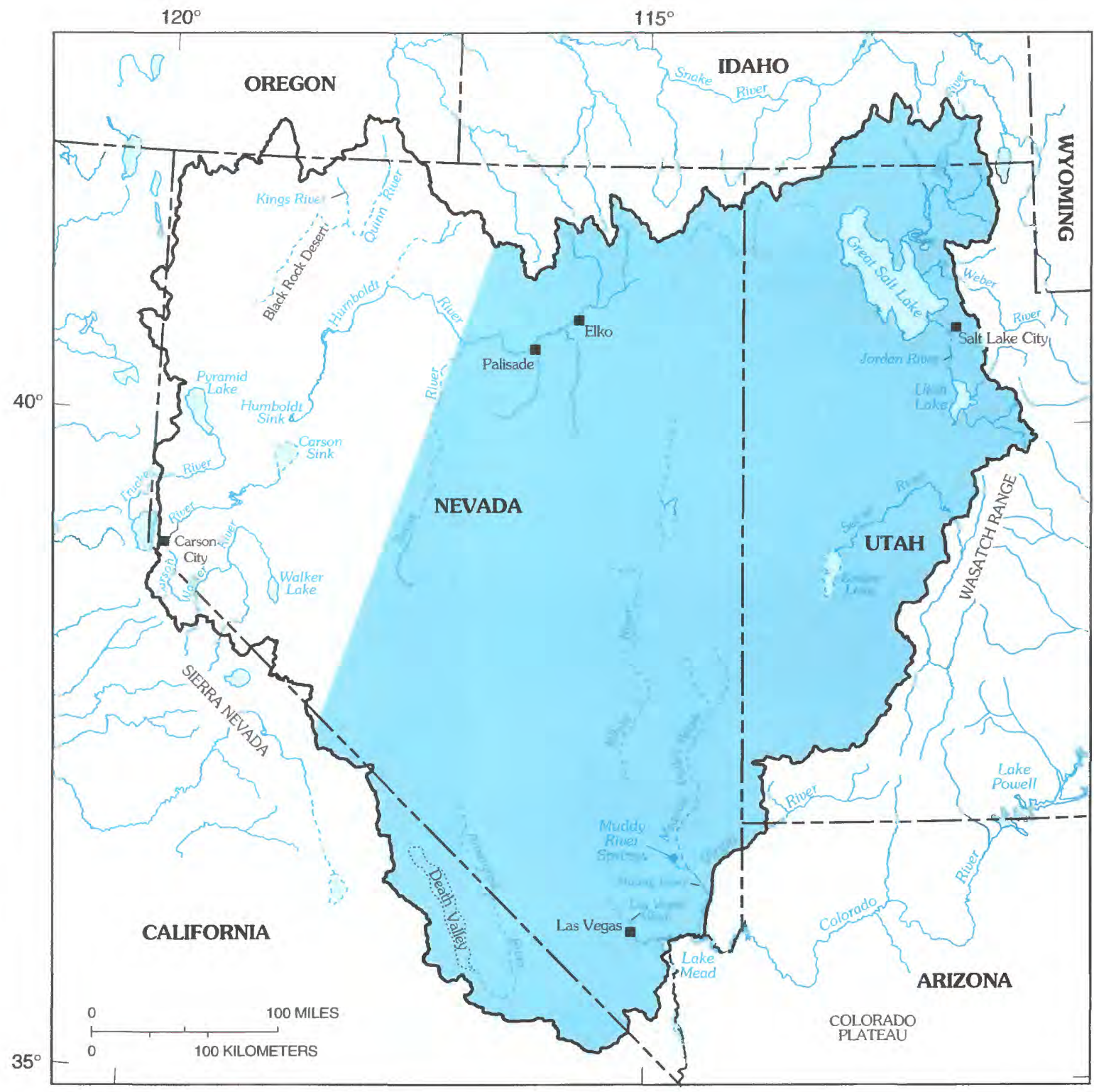

Base modified from U.S. Geological Survey digital linegraph data, 1:100,000 and 1:250,000, 1987 Albers Equal-Area Conic projection

Standard parallels $29^{\circ} 30^{\prime}$ and $45^{\circ} 30^{\prime}$, central meridian $-114^{\circ}$

\section{EXPLANATION}

Carbonate-rock province study area-Boundary is approximate

Boundary of Great Basin Regional Aquifer-System Analysis (RASA) study area

Note: Lakes and rivers dashed where ephemeral

FIgURE 5.-Distribution of rivers and lakes in and adjacent to study area for Great Basin Regional AquiferSystem Analysis. 
nology, Inc., Denver, Colo., who discovered the model-grid coding transposition discussed in the section "Purpose and Scope." Within the U.S. Geological Survey, we are grateful to Russell W. Plume, who, along with Michael D. Dettinger, helped define the regional geologic features that may affect ground-water flow in the province.

\section{GROUND WATER IN THE CARBONATE- ROCK PROVINCE}

A detailed discussion of the hydrogeology in the Great Basin, which includes the study area, is presented in a companion report by Plume (1995). A brief description of the rocks in the province and their water-transmitting properties is presented in the following section and provides a basis for understanding the occurrence and movement of ground water within the carbonaterock province.

\section{HYDROGEOLOGY}

The geologic features of the province are complex and involve rocks that range in age from Precambrian to Holocene. Its history includes major episodes of sedimentation, volcanic activity, and tectonic deformation by both compressional and extensional forces.

The oldest exposed rocks are Precambrian in age and consist mostly of gneiss, schist, and granite. The province is part of an area in which marine sediments accumulated in a shallow sea near the margin of western North America (referred to as the miogeosynclinal belt of the Cordilleran geosyncline) from late Precambrian time through the Paleozoic Era and into the early Mesozoic Era. During that period, more than $30,000 \mathrm{ft}$ of marine sedimentary rocks accumulated in parts of the province. These rocks include sequences of clastic rocks that are mostly sandstone, quartzite, and shale, and carbonate rocks that are mostly limestone and dolomite. Rocks of late Precambrian to Middle Cambrian age are dominantly clastic, and those of Middle Cambrian to early Mesozoic age are dominantly carbonates. The thickness of carbonate rocks varies within the province. The general distribution of clastic and carbonate rocks from late Precambrian to early Mesozoic age are shown in two geologic sections through the middle of the province (fig. 6).
Beginning in Mesozoic time, the environment of deposition of the rocks changed from marine to continental. Rocks of this period include (1) shale, sandstone, and conglomerate and lesser quantities of freshwater limestone and evaporite that range in age from Middle Triassic to middle or late Tertiary; (2) volcanic rocks of middle Tertiary to Quaternary age that range in composition from basalt to rhyolite; (3) intrusive rocks of Jurassic to Tertiary age that are predominantly granodiorite and quartz monzonite; and (4) since about middle Miocene time, clastic deposits, referred to as basin fill, that consist of unsorted to well-sorted clay, silt, sand, gravel, and boulders.

Geologic structure in the province is complex. Thrust faulting during the Paleozoic and Mesozoic Eras superimposed older rocks on top of younger rocks. Extensional (normal) faulting since about middle Miocene time formed the north- to northeast-trending mountains and basins that are characteristic of the entire Great Basin. Strikeslip faults found in parts of the Great Basin add to the structural complexity of the region and probably are directly associated with compressive and extensional events. Wernicke and others (1984) suggest that the strike-slip faults are mostly related to extension. Estimates of their age range from Early Jurassic to late Tertiary (Stewart, 1980, p. 86). Two major sets of strike-slip faults are present in the province: right-lateral faults in southwestern Nevada and southeastern California that form a zone referred to as the Walker belt (Stewart, 1980, p. 86), and left-lateral faults in southern and southeastern Nevada (Stewart and Carlson, 1978).

Isolated complexes of metamorphic rocks of possible Mesozoic age (termed metamorphic core complexes by Coney, 1980) have been identified at four locations in the province: the Ruby Mountains just south of Elko, the Snake Range east of Ely, the Deep Creek Range north of the Snake Range, and the Grouse Creek Mountains in northwestern Utah at the northern boundary of the Great Basin with the Snake River drainage (fig. 1). The complexes generally consist of a mobile metamorphic-plutonic basement terrane, overlain by unmetamorphosed rocks that are deformed by low-angle extensional faults. The two zones are separated by a décollement, which is a surface of dislocation (Coney, 1980, p. 15). Such complexes probably act as barriers to deep ground-water flow.

The depositional thickness and lithology of the Paleozoic sedimentary rocks are notable in their 
A

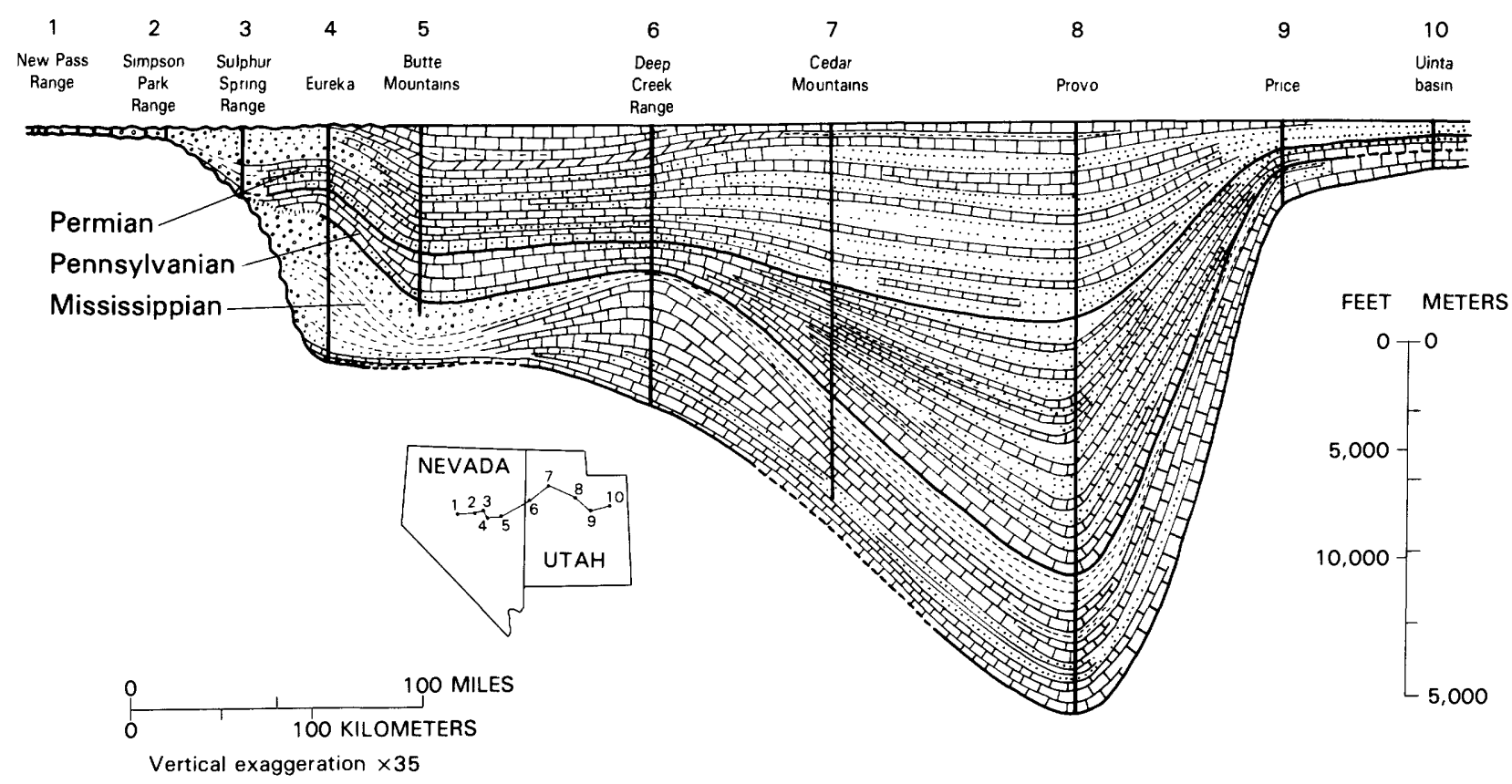

\section{B}

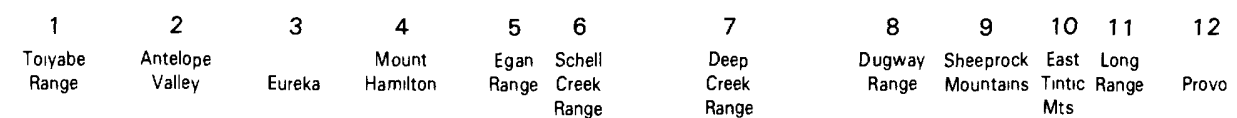

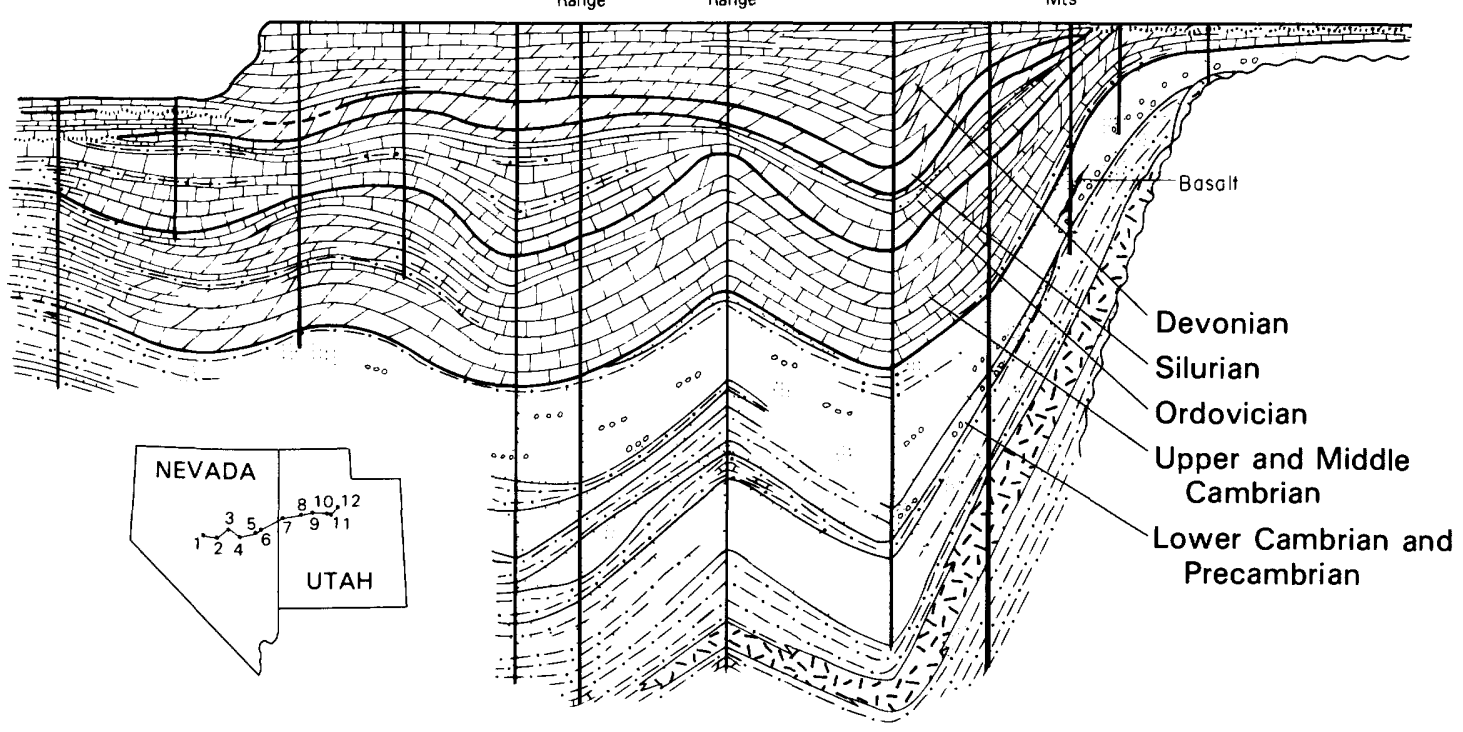

EXPLANATION

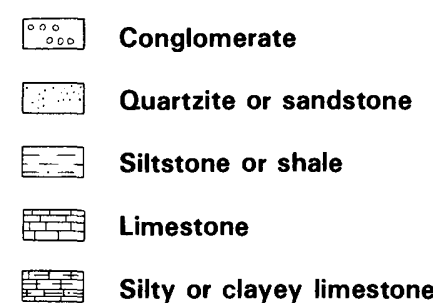

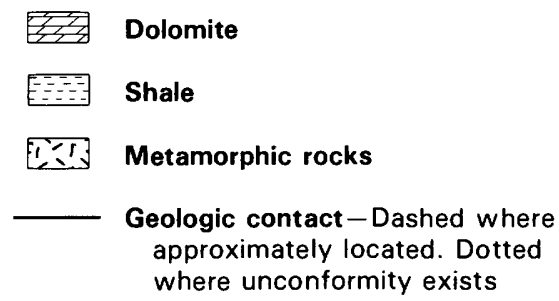


homogeneity over large areas in the province. Since deposition, however, compression, extension, intrusive and volcanic episodes, and erosion have greatly modified their distribution and thickness. The actual thickness and distribution of the various rock types at depth are not well known because the region is structurally complex and because granitic rocks are more extensive at depth than indicated by outcrops. The existence of intrusive and other crystalline rocks in the subsurface may act as barriers to regional ground-water flow. The distribution of these rocks in the carbonate-rock province was estimated from aeromagnetic anomalies by Plume (1989, 1995).

Near the south end of the province a large gravity gradient exists (Hildenbrand and Kucks, 1982; Saltus, 1984), which suggests that either the depth to Precambrian basement is much less or the rocks are more dense than in surrounding areas. This gradient is referred to as the transverse crustal boundary (Eaton, 1975; Eaton and others, 1978). The possible effects of major structures and changes in rock types on ground-water flow within the province are discussed in detail in the section "Correlation of Simulated GroundWater Flow to Regional Geologic Features."

\section{OCCURRENCE AND MOVEMENT OF GROUND WATER}

Ground water is present in all the rock types in the province. Basin-fill aquifers are the primary ground-water reservoirs. Most of the water pumped from wells is from these aquifers. Carbonate-rock aquifers that underlie much of the study area are also significant ground-water reservoirs, particularly where the rocks are fractured or where openings have been enlarged by dissolution. Most of the larger springs in the area issue from carbonate rocks or from basin fill overlying or adjacent to carbonate rocks. The other types of consolidated rocks and the fine-grained basin fill generally transmit only small quantities of water and act as barriers to ground-water flow. However, there are some exceptions to this generalization. Some volcanic rocks, namely

$\Longleftarrow$

Figure 6.-Geologic sections of Precambrian and Paleozoic rocks in carbonate-rock province (from Stewart, 1980, figs. 10 and 25). A, Northern section of Mississippian through Permian rocks. $B$, Southern section of Precambrian through Devonian rocks. basalts and welded tuffs, can yield significant quantities of water to wells where the rocks are fractured over relatively large areas. Winograd (1971) presents evidence that the welded tuffs are aquifers in the vicinity of the Nevada Test Site and in parts of Idaho. The welded tuffs are not as extensive as the basin fill or the carbonate rocks but where present could allow for the interbasin movement of ground water. The Precambrian and Lower Cambrian clastic, metamorphic, and granitic rocks beneath the carbonate rocks are relatively impermeable and probably provide a lower limit to ground-water circulation. The source of ground water in the province is precipitation that falls directly onto the province or in adjacent areas whose surface waters drain into the province (for example, the Sevier River in Utah, fig. 5). Most of the precipitation is lost by evaporation or transpired by plants. Eakin and others $(1976$, p. 6$)$ estimated that only about 5 percent of the total precipitation in the Great Basin becomes ground-water recharge. Much of the recharge is from winter and spring storms that produce heavy snows in the mountains; during spring melt, the water seeps into permeable bedrock or flows off to adjacent valleys where some of the water seeps into the basin fill. Areas estimated to recharge ground water are shown in figure 7.

Much of the ground water in the carbonaterock province is discharged by evapotranspiration (a combination of direct evaporation and transpiration by plants) on the valley floors where the ground water is near land surface. Figure 7 shows areas in the province where ground water is consumed by evapotranspiration. In addition to evapotranspiration, ground water is discharged by numerous springs. Usually, this water seeps back into the ground, is consumed by evapotranspiration, or flows to a river that ends in a terminal sink or leaves the study area. Many small springs are present in the mountains. These springs typically represent perched local systems that are not connected to surrounding and underlying ground water. Numerous small springs are also present in the valleys. These springs represent shallow ground-water flow through basin fill that originates in the adjacent mountains or associated alluvial fans. Large springs that issue from carbonate rocks or from basin fill overlying carbonate rocks are present in several of the valleys. These springs discharge ground water that has moved through the regional flow systems in the carbonate-rock aquifers from distant source areas. 


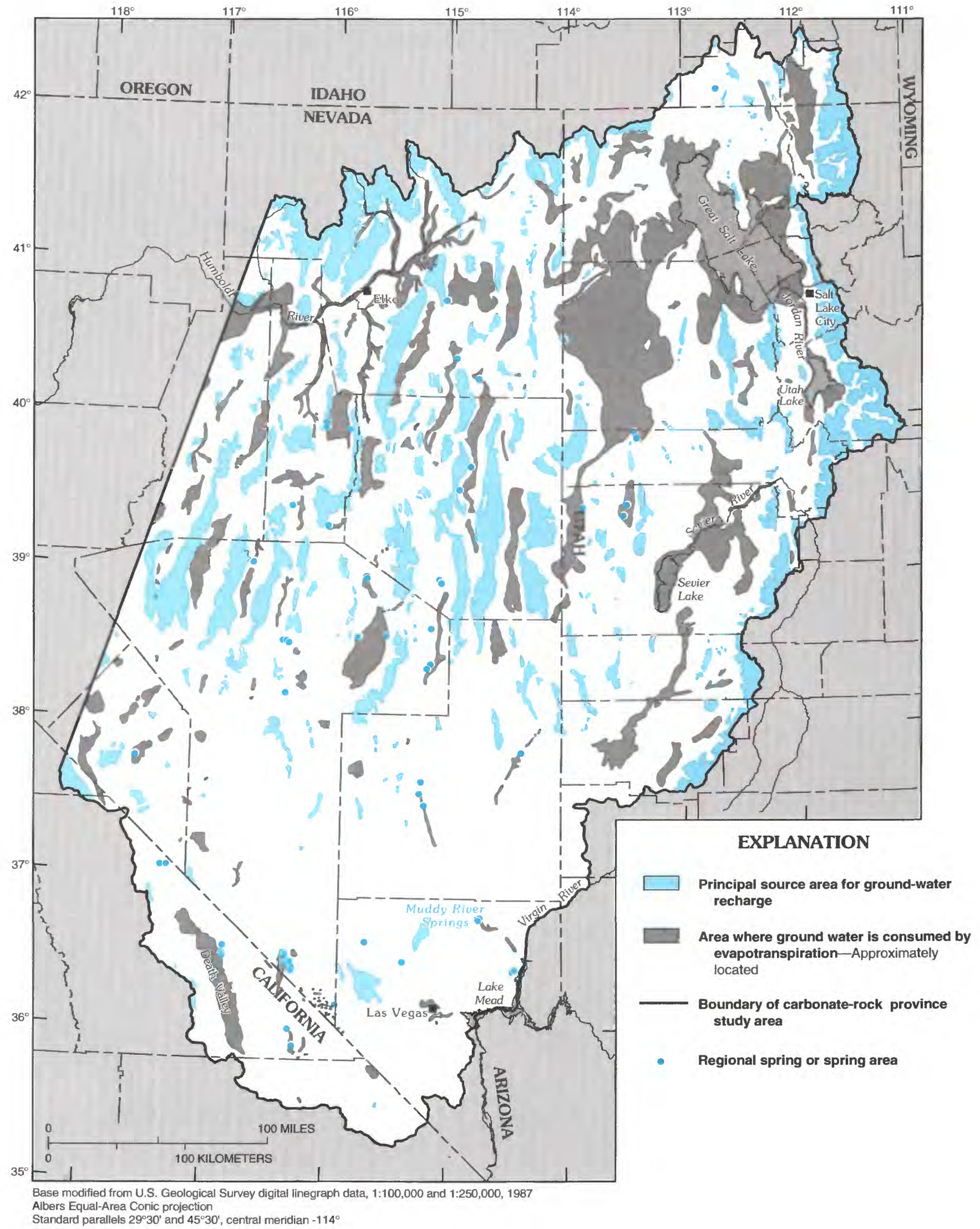


Mifflin (1968) classified springs in Nevada as local, intermediate, and regional on the basis of water chemistry, water temperature, and fluctuation of flow from the springs. Regional springs presumably represent the discharge of deep flow through carbonate rocks. Locations of the regional springs, as delineated by Thomas and others (1986) using similar criteria, are shown in figure 7 . The largest concentration of regional springs is in a small area at Muddy River Springs. The flow of these springs totals about 36,000 acre-ft/yr (Eakin and Moore, 1964).

Most ground-water withdrawals in the province are from wells drilled into the basin fill beneath the valley floors because (1) people settled in the valleys where the climate is less severe than the mountains and where the land is more suitable for agriculture, (2) ground water in many of the valleys is generally within a few feet to several tens of feet below land surface in contrast to generally deeper water levels in mountain areas, and (3) the basin fill generally yields large quantities of water to wells. Eakin and others (1976, p. 15) reported yields as much as 8,600 gallons per minute from large-capacity wells in north-central Utah.

Prior to World War II, most of the groundwater withdrawals were from flowing wells drilled into basin fill. Areas of flowing wells were concentrated largely along the eastern side of the province in valleys adjacent to the Wasatch Range, although several other valleys, including Las Vegas Valley, also had flowing wells. Ground-water withdrawals were generally small and constant until after World War II, when more efficient pumps and inexpensive energy greatly increased the quantity of ground water withdrawn to irrigate crops and to supply a rapidly increasing population. The total quantity of ground water withdrawn in the province during 1975 was approximately 1 million acre-ft. Major areas of ground-water withdrawals during 1975 are shown in figure 8.

$\Leftarrow$

FIGURE 7.-Principal source areas for ground-water recharge, areas where ground water is consumed by evapotranspiration, and regional springs (discharge exceeds 100 gallons per minute; water chemistry indicates long flow time, mostly within carbonate rocks). Recharge and evapotranspiration areas from Mifflin (1988, pl. 3); spring locations and criteria from Thomas and others $(1986$, pl. 2$)$.

\section{CONGEPTUAL EVALUATION OF GROUND-WATER FLOW}

Computer models are tools that can be used effectively to help understand complex groundwater flow systems. However, rarely are computer models used to simulate ground-water flow over such a large and geologically complex area as the carbonate-rock province. Endless arguments could be invoked as to the validity of the assumptions and hydrologic values used in simulating groundwater flow within the carbonate-rock province. For this reason, it must be stressed that the computer simulation discussed in this report is conceptual in nature. Only broad concepts and large-scale features can be inferred from the results of this study. Although a fairly detailed analysis of ground-water flow will be discussed, it does not intend to indicate that the study results presented here are adequate; in fact, the objective in presenting a detailed analysis of ground-water flow is to examine the possibility of the relatively shallow flow regions being interconnected by deep flow through carbonate rocks, and how regional geologic features might affect the direction of flow and water levels.

\section{GENERAL ASSUMPTIONS}

In the carbonate-rock province, ground-water flow takes place through the pores of basin-fill sedimentary deposits and through the fractures and solution openings of consolidated rocks. On a regional scale, flow through fractures and solution openings in the consolidated rocks is assumed to be the same as flow through a porous medium; that is, it was assumed that Darcy's Law is applicable. This assumption may be reasonable because the model grid used to simulate regional flow results in the averaging of hydraulic properties over $37.5-\mathrm{mi}^{2}$ areas. However, not enough information is available for the study area to substantiate the assumption.

Model simulations assume steady-state conditions prior to development, in which estimates of current recharge (1950-80) equal estimates of natural discharge prior to ground-water development. That is, the model does not include groundwater withdrawals. Whether current recharge equals natural discharge is unknown. During the late Wisconsin glaciation (from about 20,000 to 10,000 years ago), ground-water flow in the prov- 


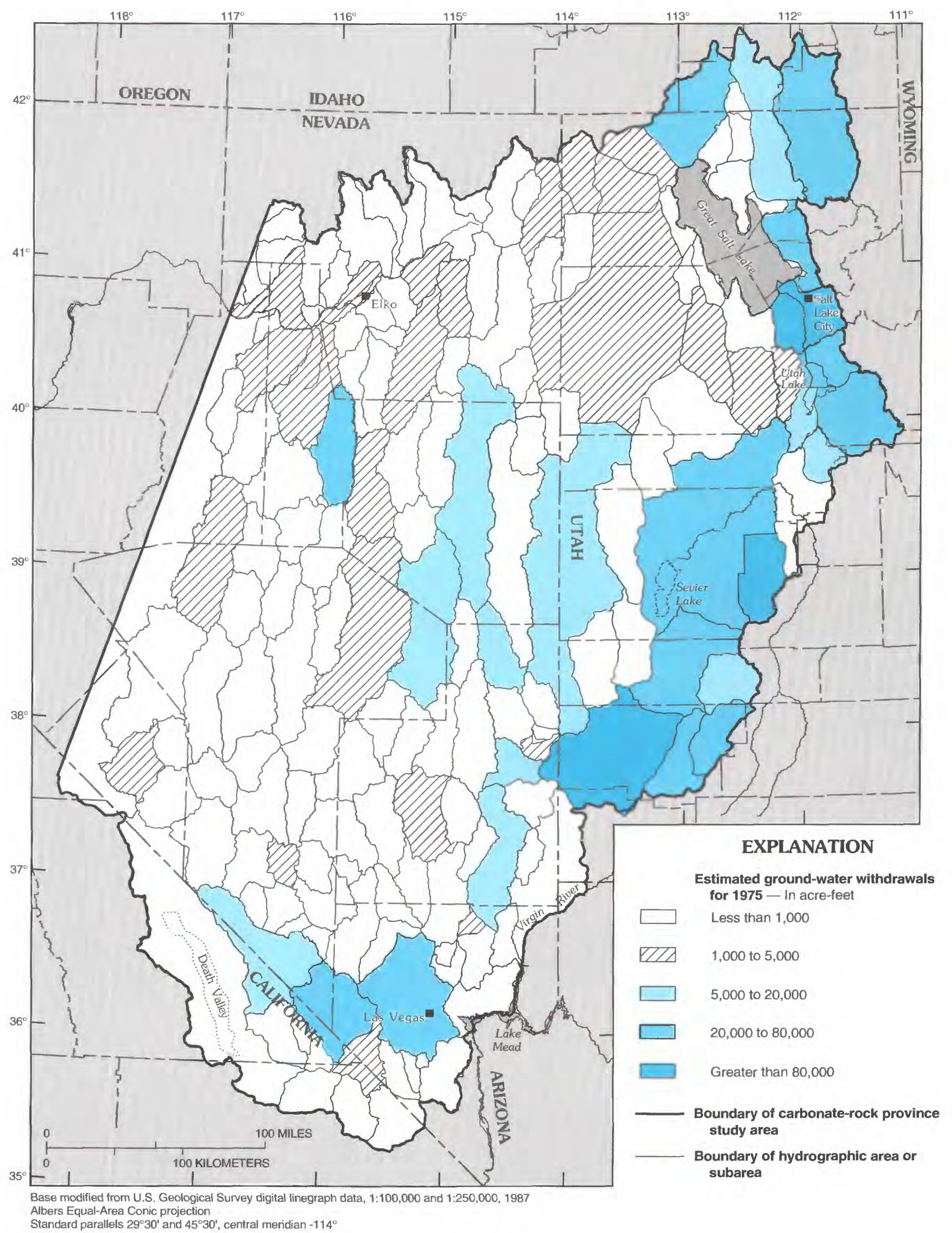


ince may have been more than that of the present day because the climate was significantly wetter, with numerous lakes in the closed basins (Hubbs and Miller, 1948). Ground-water levels and spring discharge may not be in equilibrium with the present-day recharge because of the long distances between areas of recharge and discharge. That is, the water levels and spring flows may still be declining in response to the drier climate of today relative to that of $10,000-20,000$ years ago.

Evidence of a long-term water-table decline at Ash Meadows, in the southern part of the province near Death Valley (fig. 1), is presented by Winograd and Szabo (1986). They estimated a slow rate of decline- 0.07 to $0.26 \mathrm{ft}$ per 1,000 years. This range of rates is based on (1) uraniumdisequilibrium dating of calcitic veins as much as $160 \mathrm{ft}$ (reported as 50 meters) higher than the highest present-day water level at Ash Meadows and as much as $8.7 \mathrm{mi}$ (reported as 14 kilometers) up the hydraulic gradient, and (2) the assumption that the rate of decline has been constant for the past 510,000 to 750,000 years. The calcitic veins are associated with other features indicative of paleo-ground-water discharge. Further evidence for a slow rate of water-table decline near Ash Meadows is presented by Jones (1982) in which he reports the water table beneath an alluvial fan at the Nevada Test Site has been within $160 \mathrm{ft}$ (reported as 50 meters) of the present level through most of Quaternary time. In contrast, the water table in some of the northern valleys and, in particular, the Great Salt Lake Desert must have declined at least several hundred feet over the past 10,000-20,000 years as ancestral Lake Bonneville shrank to the present level of the Great Salt Lake.

The assumption of steady-state conditions cannot be validated. However, the lack of long-term trends in measured water levels in basin fill (in areas not influenced by pumping) suggests that a dynamic equilibrium or steady state exists (at least prior to pumping) in many of the basins. Because estimates of hydraulic properties and the length of flow through the consolidated rocks are generally unknown, deeper flow through carbon-

$\leftleftarrows$

FIGURE 8.-Distribution of estimated ground-water withdrawals by hydrographic areas for 1975. Hydrographic areas from Harrill and others (1988); estimates of ground-water withdrawals for Utah from Sumison and others (1976); estimates for Nevada from Bedinger and others (1984). ate aquifers may not be in equilibrium throughout the province. If deeper flow is not in equilibrium, then present-day discharge may be responding to residual water levels related to recharge from previous wet periods, such as the last glacial epoch, and the analysis of flow presented herein may not represent actual flow everywhere.

Transmissivity in the province is assumed heterogeneous because horizontal hydraulic conductivities can change abruptly as a result of changes in lithology. Heterogeneity is simulated by varying the transmissivity among the model cells. Transmissivity within a model cell, however, is assumed homogeneous and isotropic, and is assumed to represent an average for the cell. Abrupt changes in transmissivities within a model cell are not simulated in the model. Consequently, the model is designed to simulate flow across regional changes in transmissivity.

The assumption of isotropy within a model cell is reasonable for cells corresponding to basin fill, but may be unreasonable for cells corresponding to consolidated rocks. Where flow is through fractures, the fractures may have a preferred orientation that could produce a greater transmissivity in one direction. However, anisotropic conditions may not be the same throughout the province because the orientation of fractures in consolidated i ycks is not the same everywhere. Even though some types of consolidated rock may be anisotropic, there is no compelling reason to assume a regional anistropy for the entire modeled area, and the model is not capable of simulating anistropy in individual cells. Furthermore, data is lacking to calibrate a model whereby every cell corresponding to consolidated rocks could have a greater value of transmissivity in one direction.

\section{MODEL DEVELOPMENT}

A three-dimensional finite-difference groundwater flow model developed by McDonald and Harbaugh (1988) was used for the computer simulations. The model uses the basic partial differential equation for ground-water flow in an anisotropic, heterogeneous porous medium with a constant water density:

$$
\frac{\partial}{\partial x}\left(K x x \frac{\partial h}{\partial x}\right)+\frac{\partial}{\partial y}\left(K y y \frac{\partial h}{\partial y}\right)+\frac{\partial}{\partial z}\left(K z z \frac{\partial h}{\partial z}\right)-W=S_{s} \frac{\partial h}{\partial t}
$$


where $K x x, K y y, K z z=$ hydraulic conductivity along $x$, $y$, and $z$ coordinate axes (units of length per time);

$h=$ hydraulic head, referred to as simulated water level in this report (units of length);

$W=$ volumetric flux per unit volume representing sources and (or) sinks (units of per time);

$S_{s}=$ specific storage of the medium (units of per length); and

$t=$ time.

For simulation of steady-state (equilibrium) conditions that do not include changes in simulated water level with respect to time, the right side of the equation is equal to zero and estimates of specific storage are not needed. This is the case for simulations used to conceptualize ground-water flow in the carbonate-rock province.

\section{APPLICATION OF FINITE-DIFFERENCE EQUATIONS}

The partial differential equation for groundwater flow can be closely approximated by finitedifference equations, which are sets of algebraic expressions that are solved simultaneously by using, in this model, the strongly implicit procedure (McDonald and Harbaugh, 1988, chap. 12). The solution of this algorithm involves designing a three-dimensional grid system in which each model cell within the grid exhibits specific hydrologic properties that best approximate the physical setting of that area. The model solves for unknown water level at the center of each cell (called a node) by iterating through the finite-difference equations until the simulated water-level change between the previous iteration and the current iteration is less than a specified quantity for all nodes. The original model used a closure criterion of $5 \mathrm{ft}$; the value was reduced to $0.1 \mathrm{ft}$ during the recalibration process. This closure criterion resulted in computed mass-balance errors of less than 0.05 percent. In addition to the closure criterion, the acceleration parameter (a value that increases or decreases the simulated water-level change at each iteration) was adjusted and a value of 0.8 chosen, following repeated trial simulations.

\section{MODEL GRID}

The grid system used to simulate ground-water flow in the province contains 60 columns, 61 rows, and two layers (fig. 9). The grid, oriented parallel to the generally north-northeastward trend of the fault-block mountains and adjacent valleys in the province, has rectangular cells of uniform dimension. The width of each cell is $5 \mathrm{mi}$ along the row direction (perpendicular to the fault-block mountains), and the length is $7.5 \mathrm{mi}$ along the column direction (parallel to the fault-block mountains). The length of each cell is greater than its width because the mountain ranges and valleys are typically longer than they are wide. The dimensions chosen for the grid are large enough to minimize the number of cells in the model, yet small enough to simulate the variation in topography and physiography characteristic of the province. Cells in the grid that are outside the carbonate-rock province are not used in the model simulation; each layer contains 2,456 active cells.

\section{REPRESENTATION AS A TWO-LAYER SYSTEM}

Commonly, different model layers are used to simulate different hydrogeologic units on the basis of permeability contrasts between units. However, due to the complexity of the geologic structures in the province, the uncertainty in the thickness of the hydrogeologic units, and the lack of data, the province is simply divided into two layers. The upper model layer is used to simulate relatively shallow flow primarily through basin fill and adjacent mountain ranges to depths of a few thousand feet. The lower model layer is used to simulate deep flow through consolidated rocks beneath the basin fill and mountain ranges. The actual depth to the base of deep flow is unknown, but marine sedimentary rocks containing thick sequences of carbonate rocks may be more than $30,000 \mathrm{ft}$ thick (Stewart, 1980), and freshwater has been identified from oil-exploratory wells in Railroad Valley to depths as great as $10,000 \mathrm{ft}$ (Van Denburgh and Rush, 1974, p. 31). Calculated depths of ground-water flow in the province range from about 3,700 to $10,000 \mathrm{ft}$, on the basis of temperatures and silica concentrations of water collected from selected wells and springs (Carlton, 1985, p. 34-37; Thomas and others, 1990, p. 56). A maximum depth for the lower model layer may be, therefore, about $10,000 \mathrm{ft}$.

\section{BOUNDARY CONDITIONS}

In general, the model boundaries of the carbonate-rock province extend to mountain ranges 


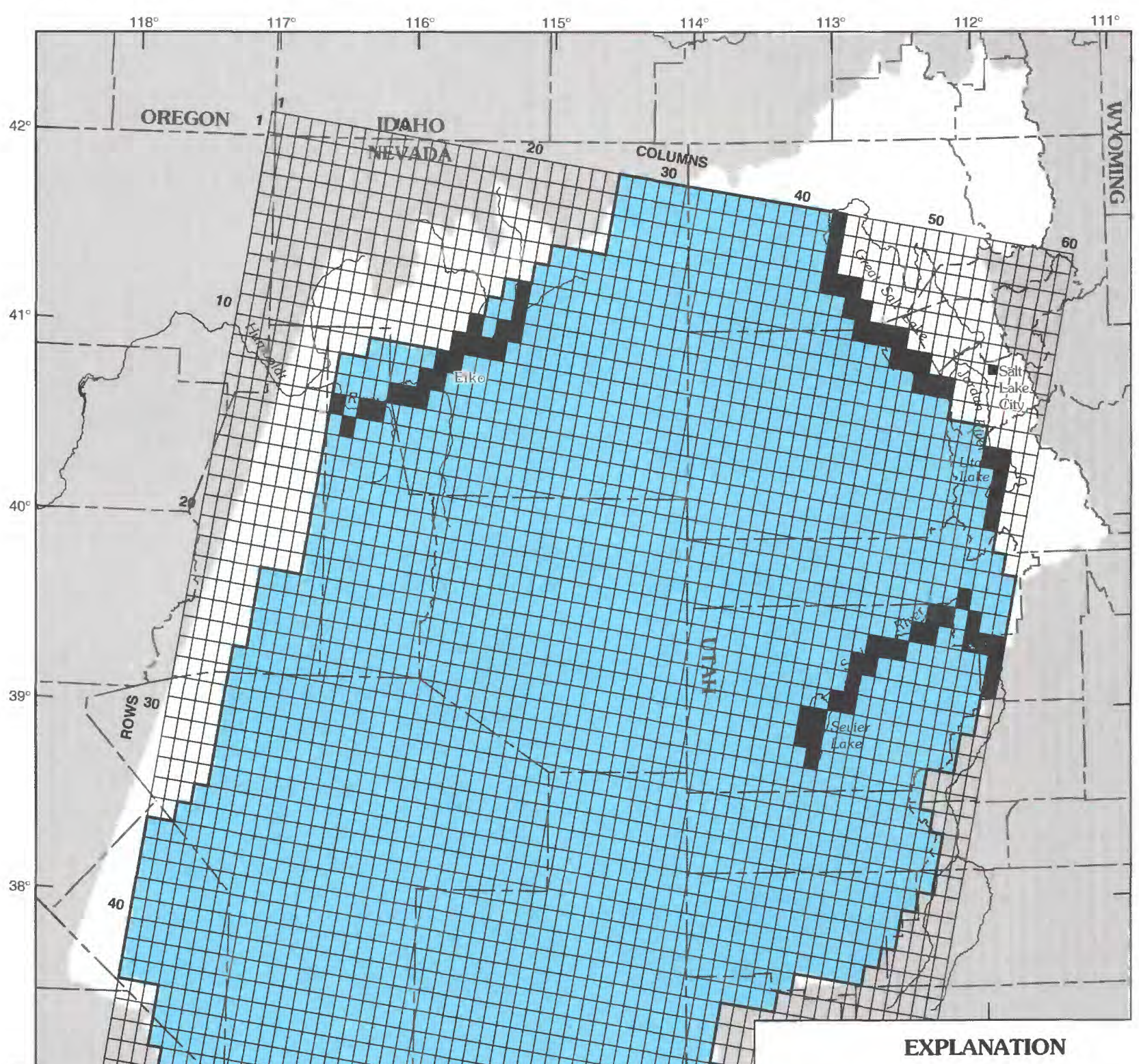

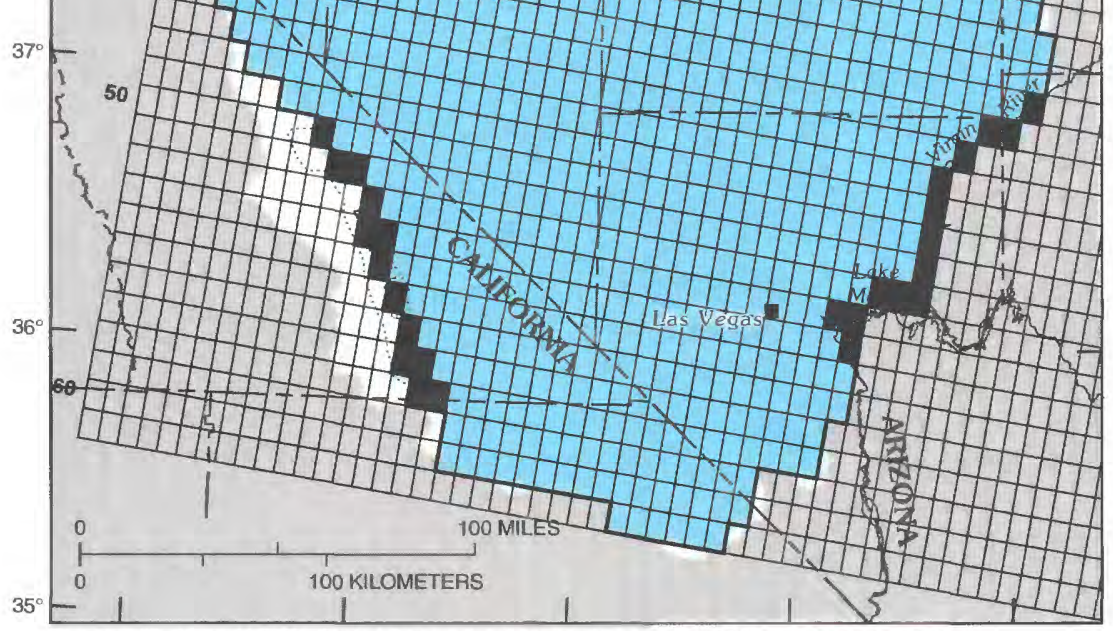

Base modified from U.S. Geological Survey digital linegraph data, 1:100,000 and 1:250,000, 1987 Albers Equal-Area Conic projection

Standard parallels $29^{\circ} 30^{\prime}$ and $45^{\circ} 30^{\prime}$, central meridian $-114^{\circ}$
Active model cells

General-head boundary cells in upper model layer

Boundary of carbonate-rock province model - Model grid superimposed over carbonate-rock province study area (shown in white) 
consisting mostly of low-permeability consolidated rocks, which are assumed to be no-flow boundaries. Carbonate rocks may extend northward beneath the basalts of southern Idaho. The topographic divide between the Snake River drainage area in southern Idaho and the Great Basin is assumed to act as a divide not only for nearsurface ground-water flow but also for deep flow. Ground-water flow to the north of the Great Salt Lake is not simulated in the model because the lake is used as a hydrologic boundary for groundwater flow in the model. The Great Salt Lake occupies a low area with no surface outflow, and it presumably is a sink for ground-water flow in the northern part of the province. Carbonate rocks may also extend westward from where the rocks are exposed in the mountains. The western boundary of the modeled area is along mountain ranges in which the Paleozoic strata consist mostly of transitional-assemblage sedimentary rocks (Plume and Carlton, 1988, fig. 2). Although small quantities of ground water may flow across these mountain ranges, the western boundary is simulated as a no-flow boundary. A no-flow boundary is also simulated beneath the lower model layer. The boundary represents the depth below which there is little ground-water flow. The depth of the noflow boundary beneath the lower layer is unknown because the depth below which flow ceases is generally unknown. Presumably, ground water does not flow through the underlying Precambrian and Lower Cambrian rocks.

Hydrologic boundaries are also used in three other places along the edge of the modeled area: Utah Lake, the Virgin River and Lake Mead, and Death Valley (see figs. 5 and 9). These hydrologic boundaries are simulated as head-dependent flow boundaries to the upper model layer, using the general-head package of McDonald and Harbaugh (1988, chap. 11). Flow across the headdependent flow boundaries is computed by multiplying the water-level difference across the boundary with a hydraulic conductance term. The water-level difference is determined by comparing a specified head assigned to the boundary with a simulated water level in the upper layer cell. The hydraulic conductance term is the hydraulic conductivity times the cross-sectional area of the boundary through which flow is simulated divided by the length of the flow path.

The head-dependent flow boundary allows flow either to or from the model cell depending on whether the simulated water level in the cell is less than or greater than the specified head. The boundary is applied above the upper model layer, thus the conductance term used for each model cell is in the vertical direction. An initial estimate of vertical conductance was determined for each cell by multiplying an approximate vertical hydraulic conductivity with the planimetric area of the model cell and then dividing by an estimate of the vertical flow-path length. The length of the flow path is assumed to be half the estimated thickness of the basin fill, which probably represents the average value of the flow length. The conductance terms were adjusted during model calibration.

The same type of boundary is used to simulate the interaction of ground-water flow with the Sevier and Humboldt Rivers and selected tributaries to the Humboldt River, where rivers flow into or out of the modeled area (see figs. 5 and 9). The area used to compute the conductance term for each model cell is the area of the river within the cell.

Specified heads for the head-dependent flow boundaries were estimated by overlying the model grid onto U.S. Geological Survey 1:250,000-scale topographic maps corresponding to the modeled area. Specified heads for lakes are based on values listed on the maps, specified heads for dry lakes are based on the land-surface altitudes of the dry lakes, and specified heads for rivers were estimated by approximating the average stream altitude for each reach corresponding to a model cell. Specified heads for the Humboldt River range from 4,650 ft (cell: row 14, column 9) to $5,500 \mathrm{ft}$ above sea level (cell: row 7 , column 21). Specified heads of $4,200 \mathrm{ft}$ and 4,475 ft were assigned to cells corresponding to the Great Salt Lake and Utah Lake, respectively. A specified head of 4,519 $\mathrm{ft}$ was assigned to Sevier Lake, and specified heads for the Sevier River range from 4,525 ft (cell: row 24 , column 49) to $5,100 \mathrm{ft}$ (cell: row 22 , column 60 ). Specified heads for the Virgin River range from 1,400 ft (cell: row 48, column 41) to 1,650 ft (cell: row 45, column 45). Specified heads for Lake Mead range from $1,200 \mathrm{ft}$ near the dam (cell: row 53 , column 37 ) to $1,205 \mathrm{ft}$ near the confluence with the Virgin River (cell: row 49, column 41). A specified head of $800 \mathrm{ft}$ above sea level was assigned to the Colorado River below the dam (cell: row 54, column 38). Specified heads for Death Valley range from $270 \mathrm{ft}$ below sea level in the central part (cell: row 54 , column 14) to $10 \mathrm{ft}$ above sea level at the north and south ends (cells: row 50, column 10 , and row 58, column 18 ). 
Recharge to the model is simulated as a constant flux to the upper model layer in cells that correspond to mountain ranges. Recharge is not simulated in model cells that correspond to valleys, because much of that recharge does not infiltrate into the deep part of the aquifer system. Recharge in the valley is assumed to discharge within the same general area, either as evapotranspiration or as flow to small springs.

Evapotranspiration is the principal mode of ground-water discharge in the study area. This discharge is simulated as a head-dependent flow boundary in the upper model layer using the evapotranspiration package of McDonald and Harbaugh (1988, chap. 10). The simulation is based on a discontinuous function related to land surface (fig. 10A). Information required includes the land-surface altitude of each model cell, the evapo-

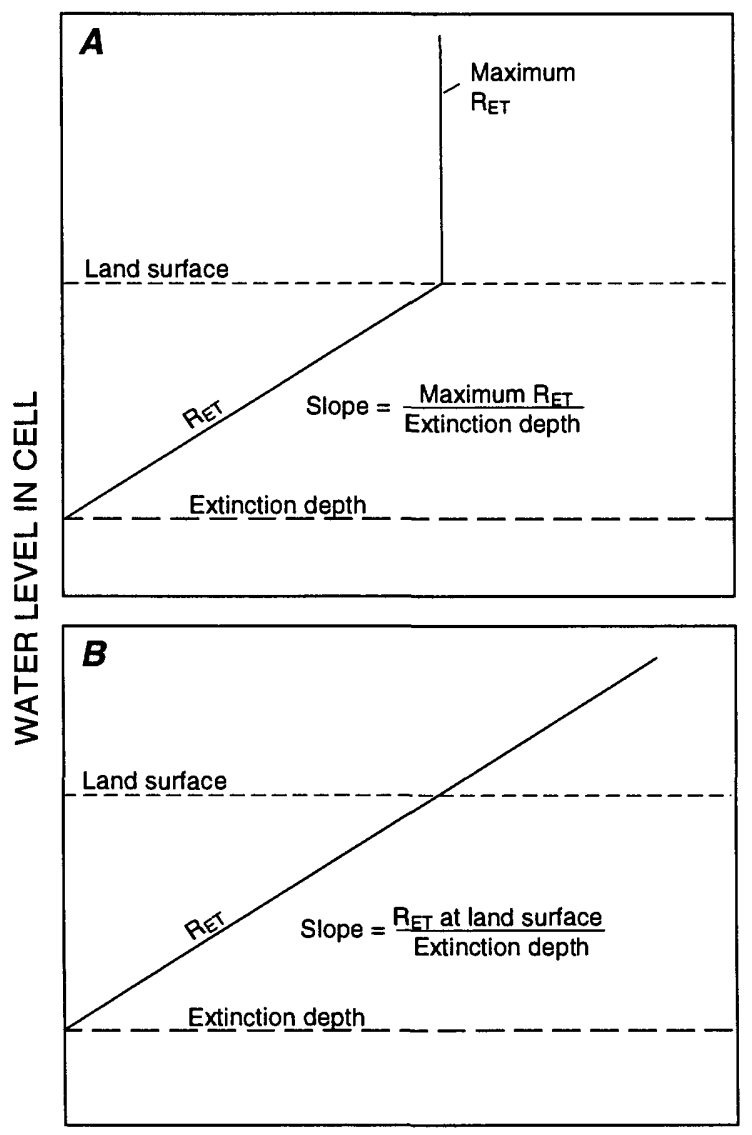

EVAPOTRANSPIRATION RATE

Figure 10.-Simulations of evapotranspiration as a function of water level in a model cell, where $\mathrm{R}_{\mathrm{ET}}$ is evapotranspiration rate. $A$, Discontinuous function given by McDonald and Harbaugh (1988, chap. 10). $B$, Modified function used herein to reduce numerical oscillation (see text section titled "Boundary Conditions"). transpiration rate at land surface, and the depth below land surface where evapotranspiration ceases (extinction depth).

The equation used to simulate evapotranspiration was modified because numerical oscillations developed in some cells during initial simulations as a result of the discontinuous function at land surface. To alleviate the oscillations, the equation was changed so evapotranspiration rates continued to increase even when the simulated water level in a cell was above land surface (fig. 10B). Although this reduced the numerical oscillations in the model, the simulated water level in cells with evapotranspiration were compared with land surface following each simulation to determine if the water level in a cell exceeded land surface and produced an unrealistic discharge. Where it did, transmissivities and vertical leakances were changed to lower the simulated water level.

Land-surface altitude, evapotranspiration rate at land surface, and extinction depth are specified for all active cells in the upper layer. A uniform extinction depth of $20 \mathrm{ft}$ is assumed. Evapotranspiration rates at land surface vary from 42 in. in the northern part of the study area to 72 in. in the extreme southern part, and generally follow the distribution of annual lake-evaporation rates for the period 1946-55 presented by Kohler and others (1959, pl. 2). A lower rate of 12 to $25 \mathrm{in} / \mathrm{yr}$ is assumed in the Great Salt Lake Desert because, in areas where ground water has a high salinity, the rate of evaporation and transpiration is less (van Hylckama, 1974, p. 28). Landsurface altitude for all model cells was determined from digital elevation data obtained from the $\mathrm{Na}$ tional Geophysical Data Center (National Oceanic and Atmospheric Administration, Boulder, Colo.). These data represent a regular sampling of landsurface altitudes at an interval of 1 minute in geographic coordinates. This corresponds to a spacing between values of about $4,800 \mathrm{ft}$ in an eastwest direction and about $6,000 \mathrm{ft}$ in a north-south direction. Approximately 35 altitude values were used to compute the average land-surface altitude of each model cell.

Only a few of the numerous springs discharging in the study area are specifically simulated by discharge cells in the model. Most small springs in the study area are assumed to be discharging from the upper model layer. This springflow is included in the simulated evapotranspiration. All large springs, and several smaller springs listed by Thomas and others (1986, pl. 2), are herein termed "regional springs." The flow of these 
springs is simulated as discharge from the lower model layer, and therefore is not a component of simulated evapotranspiration from the upper layer. Model cells corresponding to springs or a group of springs simulated as discharging from the lower layer are shown in figure 11. In Death Valley, spring flow from Texas, Nevares, and Travertine Springs near Furnace Creek is not simulated as discharge from the lower layer, because it is included in the discharge from the head-dependent flow boundary.

The drain package (McDonald and Harbaugh, 1988, chap. 9) is used to simulate spring discharge from cells in the lower model layer that correspond to the location of selected regional springs. Discharge from these cells is simulated whenever the water level in the cell exceeds a specified head for the drain. No discharge is simulated whenever the water level is below the specified head. Land-surface altitudes of the springs, listed by Thomas and others (1986, pl. 2), are used as the specified head. A representative altitude is used in cells that include more than one spring. Discharge from the drain (spring) is also dependent on a conductance term (McDonald and Harbaugh, 1988, chap. 9, p. 5). A single conductance value is used for all springs. Initially, a value of $3 \mathrm{ft}^{2} / \mathrm{s}$, large enough that discharge from the cell was not controlled by the conductance term but rather by transmissivity of cells in the lower layer, was used. The value was increased to $10 \mathrm{ft}^{2} / \mathrm{s}$ during model calibration without any effects to simulated spring discharge.

\section{MODELING APPROACH}

Simulation of ground-water flow in the carbonate-rock province required a slightly different approach from that used for most modeled areas, because all the variables in the ground-water flow equation (eq 1) either are unknown over large parts of the area or are only approximately known. The locations of recharge and discharge areas are generally known, although the quantities of recharge and discharge are only approximately known. Water levels in the upper part of the basin fill are generally known (Thomas and others, 1986), but water levels in the consolidated rocks beneath the basin fill are known only at a few locations. Also, the existing water-level measurements represent only the uppermost part of the basin fill and the consolidated rocks, because wells penetrate only a small part of their total thick- nesses. Water levels are generally unknown in the mountains because only a few wells exist there. Hydraulic properties of shallow basin fill are generally known because numerous wells have been drilled into the basin fill. Estimates of hydraulic properties of the various consolidated rocks are largely unknown, except at a few locations such as the Nevada Test Site. In addition, the subsurface geology is largely unknown, as is the depth of ground-water flow.

The general approach used to simulate regional ground-water flow in the province was to adjust transmissivities and vertical leakances until (1) water levels in both model layers approximated the estimated water levels, (2) evapotranspiration in the upper layer approximated the quantity and distribution of ground-water evapotranspiration estimated for each hydrographic area, and (3) simulated discharge from the lower layer approximated the discharge at regional springs.

Estimated water levels used to compare with simulated values are based on contours by Thomas and others (1986) in both the basin fill and consolidated rocks. Water-level data are concentrated in the basin fill because these deposits generally yield at least moderate quantities of water at shallow depth. The locations of measured wells in basin fill are shown in figure 12. In contrast, water-level data in consolidated rocks are sparse. These data include measurements from wells, test holes, or mine shafts that penetrate consolidated rocks in the mountains or beneath the basin fill, and land-surface altitudes at regional springs (Thomas and others, 1986, pl. 2). The locations of measured wells, test holes, and mine shafts completed in consolidated rocks are shown in figure 13.

For initial model calibration, a water-level altitude was estimated for each cell in the upper model layer and for selected cells in the lower layer. A water-level altitude was estimated for cells in the upper layer by superimposing the model grid over the map of water levels in basin fill (Thomas and others, 1986, pl. 1) and determining an average water level for each cell in an area where water-level contours had been drawn. Water-level contours drawn by Thomas and others for some basins, in particular Las Vegas Valley, show the effects of ground-water withdrawals. In these basins, water levels measured prior

Figure 11.-Cells used to simulate spring discharge from lower model layer. Cells correspond to selected springs shown in figure 7. 

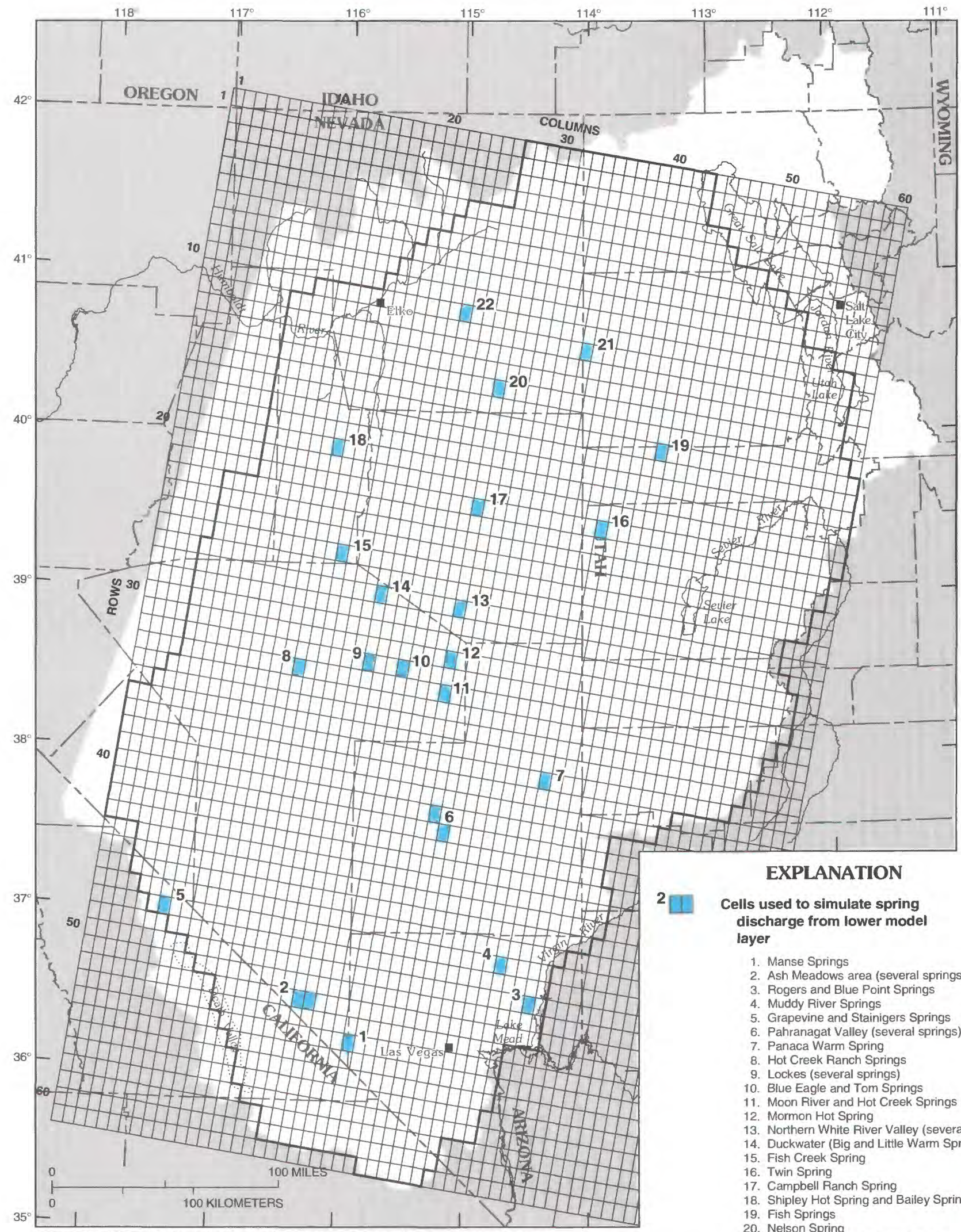

\footnotetext{
Cells used to simulate spring discharge from lower model

layer

1. Manse Springs

2. Ash Meadows area (several springs)

3. Rogers and Blue Point Springs

4. Muddy River Springs

5. Grapevine and Stainigers Springs

6. Pahranagat Valley (several springs)

7. Panaca Warm Spring

8. Hot Creek Ranch Springs

9. Lockes (several springs)

10. Blue Eagle and Tom Springs

11. Moon River and Hot Creek Springs

12. Mormon Hot Spring

13. Northern White River Valley (several springs)

14. Duckwater (Big and Little Warm Springs)

15. Fish Creek Spring

16. Twin Spring

17. Campbell Ranch Spring

18. Shipley Hot Spring and Bailey Spring

19. Fish Springs

20. Nelson Spring

21. Blue Lake and Little Salt Springs

22. Warm Springs
}

Standard parallels $29^{\circ} 30^{\prime}$ and $45^{\circ} 30^{\prime}$, central meridian $-114^{\circ}$ 


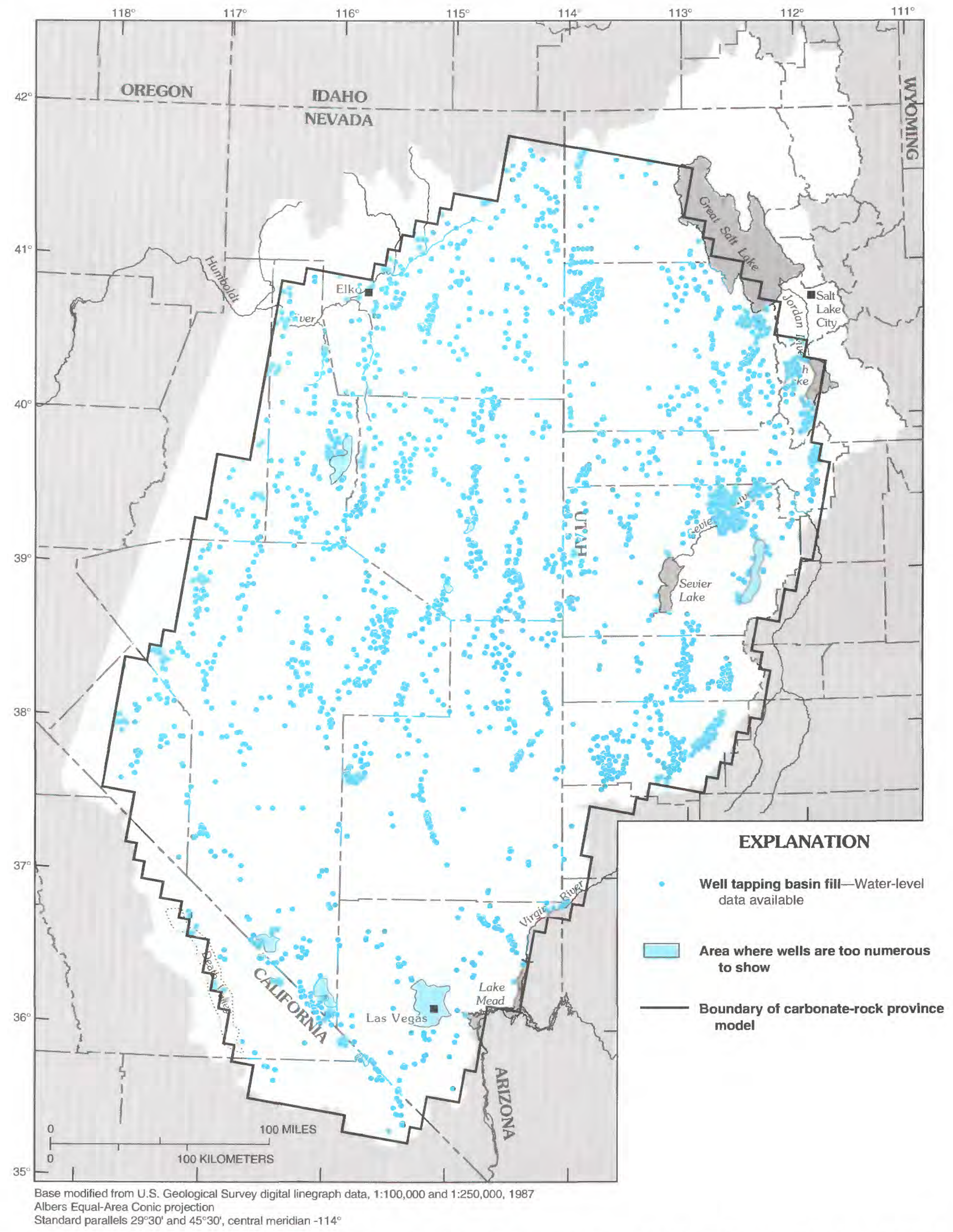

FIGURE 12.-Wells tapping basin fill for which water-level data are available (modified from Thomas and others, 1986, pl. 1). 


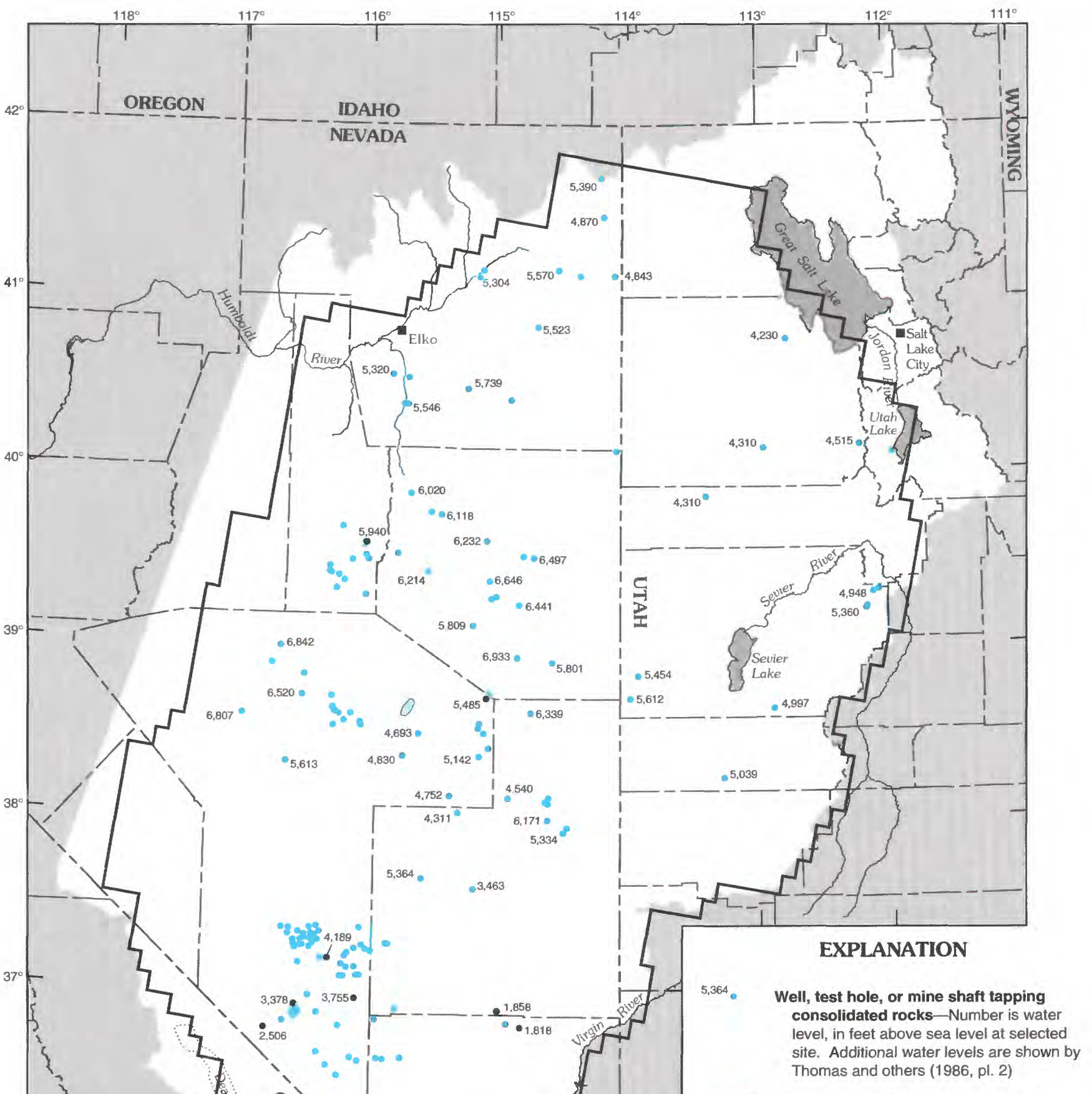

Area where wells are too numerous to show

Boundary of carbonate-rock province model

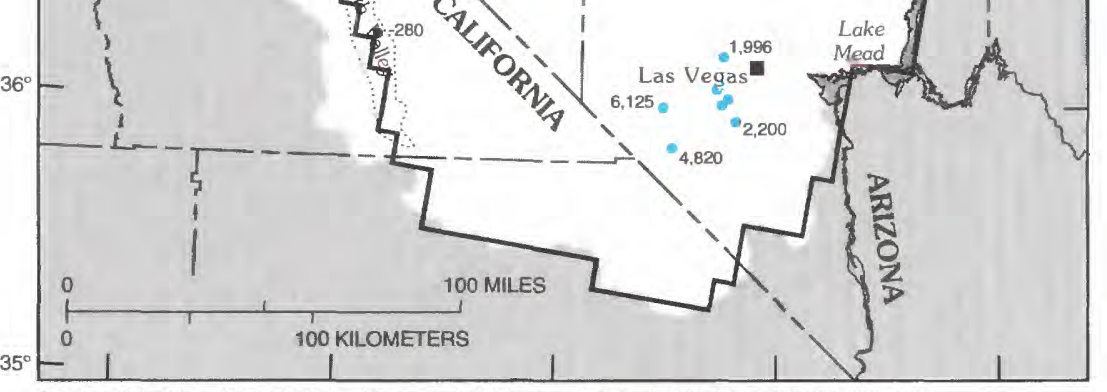

Base modified from U.S. Geological Survey digital linegraph data, 1:100,000 and 1:250,000, 1987 Albers Equal-Area Conic projection

Standard parallels $29^{\circ} 30^{\prime}$ and $45^{\circ} 30^{\prime}$, central meridian $-114^{\circ}$

Figure 13.-Wells, test holes, and mine shafts tapping consolidated rocks for which water-level data are available (modified from Thomas and others, 1986, pl. 2). 
to the withdrawals were used. Water-level altitudes in cells corresponding to basins with sparse data were estimated from the measurements at individual wells, from the altitude of springs discharging on the valley floor, or from an average altitude of areas of evapotranspiration. Water-level altitude for cells corresponding to mountainous regions was interpolated from adjacent valleys and from the average land-surface altitude estimated for the cell. A water-level altitude was estimated for some cells in the lower model layer by superimposing the model grid over the map of waterlevel contours for consolidated rocks (Thomas and others, pl. 2). The value assigned to a cell corresponded to the average altitude indicated by the contours. Most cells in the lower layer do not have an estimated water level.

For final model calibration, the estimated water-level altitudes of only selected cells were used to compare with simulated water levels. Cells in the upper model layer were selected if they corresponded to (1) an area where water-level contours in basin fill had been drawn by Thomas and others (1986, pl. 1) or (2) a measured water level in a well. Cells in the lower layer were selected if they corresponded to a measured water level in a well, test hole, or mine shaft, or the land-surface altitude of a regional spring. In the upper layer, 773 cells out of a total 2,456 active cells had an estimated water level, whereas in the lower layer, only 144 cells out of 2,456 had an estimated water level.

\section{ESTIMATES OF RECHARGE}

The method used to estimate recharge in $\mathrm{Ne}$ vada and Utah is reported by Maxey and Eakin $(1949$, p. 40,41$)$ and Eakin and others (1951, p. $26,27)$. Their method assumes that recharge is principally from precipitation in the mountains. The quantity of recharge is based on a percentage of the total volume of annual precipitation that falls within a selected altitude interval. Percentages range from 0 percent for areas where annual precipitation is less than $8 \mathrm{in}$. to as much as 40 percent in the highest parts of the Wasatch Range, where annual precipitation is more than $40 \mathrm{in}$. The original percentages listed by Maxey and Eakin (p. 40,41) are based on trial-and-error calculations in which estimates of recharge are set equal to estimates of ground-water discharge from natural losses. Although recharge is estimated by this empirical method in Utah, the percentage of recharge applied to each precipitation zone varies considerably between hydrographic areas. The reason for the variation is that the estimates of recharge are adjusted to match estimates of discharge. The original percentages of recharge applied to each precipitation zone have also been adjusted subjectively when applied to other hydrographic areas in Nevada. Thus, the percentage of precipitation estimated to become recharge for a particular precipitation zone may vary by several percent among different hydrographic areas in both Nevada and Utah. Watson and others (1976) quantitatively evaluated the method for estimating recharge and concluded that the method could not reliably predict recharge other than provide an approximation.

Estimates of recharge for a given mountain range were obtained by determining the areas within each precipitation zone from maps of average annual precipitation for Nevada and Utah (Hardman, 1936, 1965; U.S. Weather Bureau, 1963). The estimate of recharge for each mountain range was then compared and revised to be consistent with the estimated recharge for individual hydrographic areas or selected groups of areas. Finally, the distribution of recharge areas was compared with areas of principal recharge as delineated by Mifflin (1988, pl. 3). The distribution of recharge assigned to cells in the model is shown in figure 14 .

Total annual recharge within the modeled area is about 1.5 million acre-ft. The quantity of precipitation that is estimated to recharge the aquifers in the province is about 3 percent of the estimated total annual precipitation. This approximation is slightly less than the 5 percent reported by Eakin and others (1976, p. 6). However, they include hydrographic areas that receive water from the much wetter Sierra Nevada, the mountains in extreme northern Nevada, and areas along the north and east sides of the Great Salt Lake that receive some water from the Wasatch Range. They also exclude several hydrographic areas in the much drier southeastern Nevada. Thus, the 3-percent estimate is probably reasonable. Also, the estimates of recharge presented herein, and in most of the numerous reconnaissance reports, do not include water that locally recharges ground water only to be discharged nearby.

Figure 14.-Distribution of recharge assigned to cells in upper model layer, and simulated recharge from rivers and lakes through general-head boundaries. 


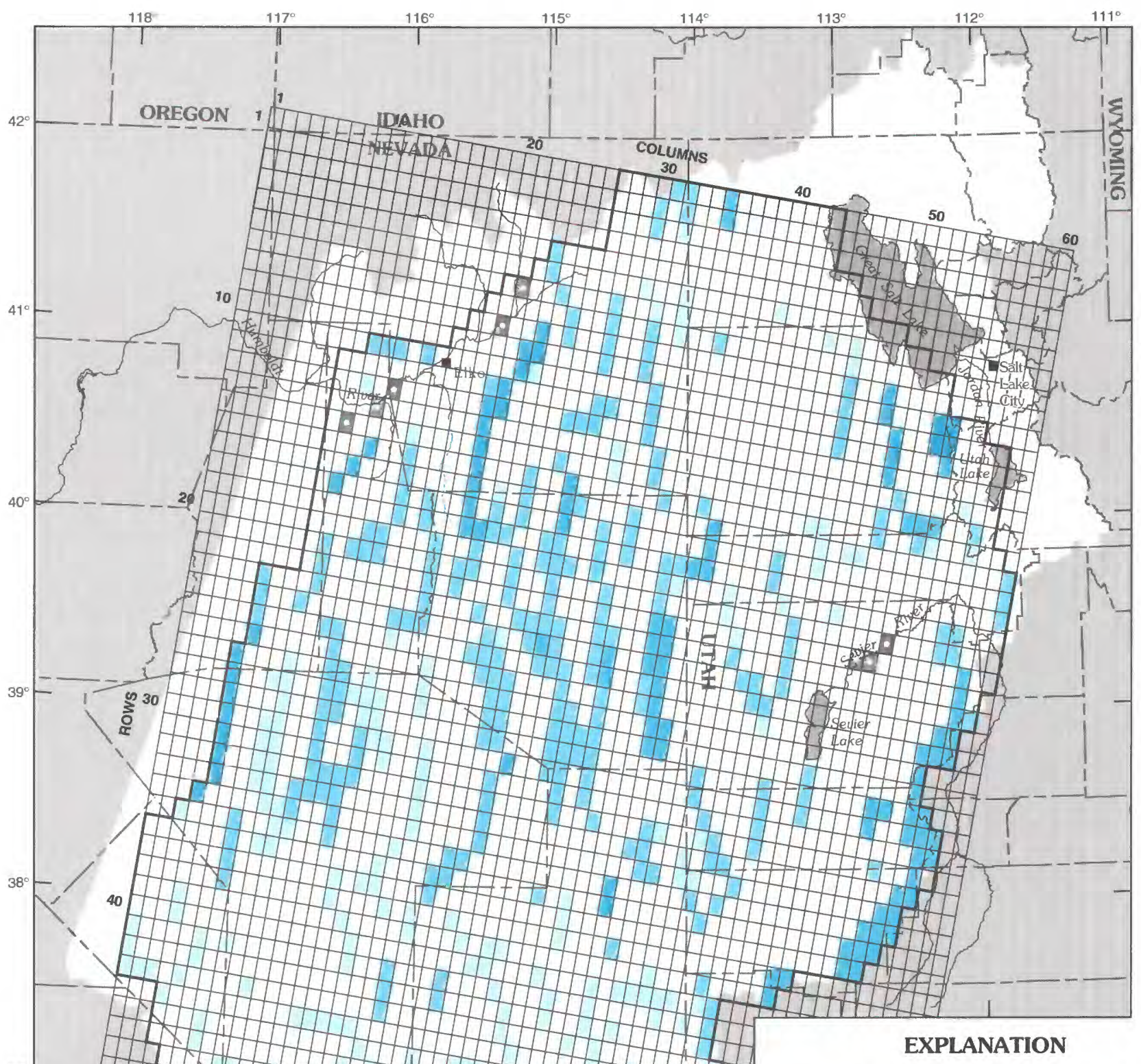

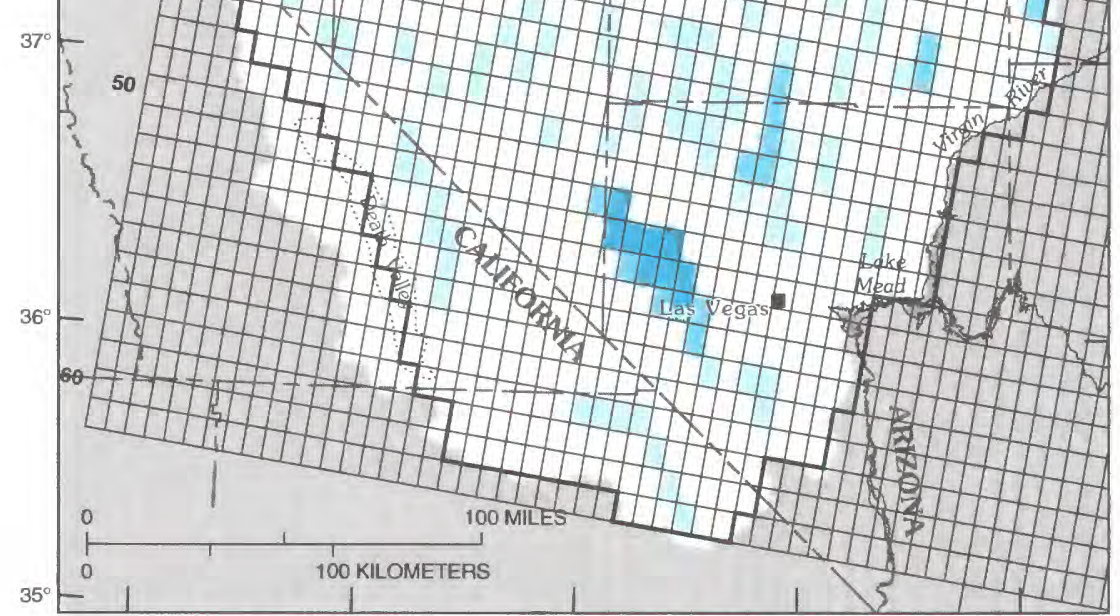

Base modified from U.S. Geological Survey digital linegraph data, 1:100,000 and 1:250,000, 1987 Albers Equal-Area Conic projection

Standard parallels $29^{\circ} 30^{\prime}$ and $45^{\circ} 30^{\prime}$, central meridian -114
Recharge rates for cells in upper model layer-In acre-feet per year

No recharge

Less than 1,000

1,000 to 5,000

5,000 to 10,000

Greater than 10,000

- Recharge at general-head boundary Flow exceeds 40 acre-feet per year

model 


\section{INITIAL ESTIMATES OF TRANSMISSIVITY AND LEAKANCE}

Initial estimates of transmissivity for the upper model layer are grouped into three geologic units. The estimates were made to provide a starting point for the calibration process in which transmissivities were modified. The geologic units within the modeled area are grouped into three principal types (Harrill and others, 1988; Plume and Carlton, 1988): (1) basin fill, which includes Tertiary tuffs, terrigenous sediments, and Quaternary stream, alluvial fan, and lacustrine deposits; (2) thick sequences of carbonate rocks of Paleozoic and early Mesozoic age; and (3) other consolidated rocks, which include clastic sedimentary rocks, intrusive and extrusive igneous rocks, metamorphic rocks, and locally thick units of Tertiary clay and silt. Figure 15 shows how the principal rock types are distributed in the upper layer. The basin-and-range physiography can be easily distinguished with the resolution provided by the 5-mi by 7.5-mi grid.

Carbonate rocks are assumed to have the highest transmissivity. The initial transmissivity assigned to cells in the upper model layer representing carbonate rocks was $0.25 \mathrm{ft}^{2} / \mathrm{s}$, within the range of values reported by Winograd and Thordarson (1975, table 3 and p. 73), Bunch and Harrill (1984, p. 119), and Plume (1989). Reported values range from about $0.002 \mathrm{ft}^{2} / \mathrm{s}\left(200 \mathrm{ft}^{2} / \mathrm{d}\right)$ to about $9 \mathrm{ft}^{2} / \mathrm{s}\left(800,000 \mathrm{ft}^{2} / \mathrm{d}\right)$. Initial transmissivity assigned to cells representing other consolidated rocks was $0.002 \mathrm{ft}^{2} / \mathrm{s}$; the initial value assigned to cells representing basin fill was 0.02 $\mathrm{ft}^{2} / \mathrm{s}$, within the range of values presented by Winograd and Thordarson (1975, table 3 ) and Bunch and Harrill (1984, p. 115). A uniform value of $0.25 \mathrm{ft}^{2} / \mathrm{s}$ was initially assigned to all cells in the lower layer.

Transmissivities of each rock type actually vary widely due to either changes in thickness or differing hydrologic properties of the rocks. The transmissivities for each model cell changed during model calibration. The vertical resistance to ground-water flow is simulated in the model with a vertical leakance term. Vertical leakance is defined as the vertical hydraulic conductivity divided by length of flow path (Lohman, 1972, p. 30 ). A vertical leakance of $1 \times 10^{-11}$ per second was initially assumed for all cells. No attempt was made to distinguish leakance values according to hydrogeologic conditions because of the uncertainty of the geologic units at depth and because of uncertainties in estimating the vertical hydraulic conductivity and the length of the flow path. The vertical leakances also changed during model calibration.

\section{MODEL CALIBRATION}

Initial model calibration began by assigning an estimated water level to each model cell. In many cells, particularly in the lower layer, the assigned water levels were interpolated and extrapolated from data many miles away. Transmissivities of cells in the upper and lower model layers and vertical leakances of cells between layers were initially adjusted on the basis of comparing simulated water levels to those assigned to the model cells. Two computer programs were written and used to automatically adjust both transmissivities and vertical leakances. The first program adjusted transmissivities in cells where the simulated water levels were either too high or too low compared to the assigned water levels. Transmissivities were increased or decreased depending on the ratio of the simulated water level to the assigned water level. The method worked reasonably well because simulated heads were either too high or too low over large regions of the model.

The second program adjusted vertical leakances between adjacent cells in the upper and lower model layers during alternate simulations. Vertical leakances were adjusted using the ratio of the simulated water-level difference to the assigned water-level difference as expressed in the following equation (Williamson and others, 1989, p. 32):

$$
\text { Lnew }=\text { Lold } * \mathrm{FAC} *(\Delta \mathrm{HVmod} / \Delta \mathrm{HVas})
$$

where Lnew $=$ the adjusted vertical leakance value;

Lold $=$ the previous vertical leakance value;

$\Delta H V m o d=$ the simulated water-level difference of adjacent cells between the upper and lower model layers;

$\Delta$ HVas $=$ the assigned water-level difference of adjacent cells between the upper and lower model layers; and

$\mathrm{FAC}=0.9$ when the ratio of $\Delta \mathrm{HVmod}$ to $\Delta$ HVas is less than $1,1.1$ when the ratio is greater than 1 , and 1.0 when the ratio is 1 .

The computer programs do not correctly adjust transmissivities or vertical leakances on the first 

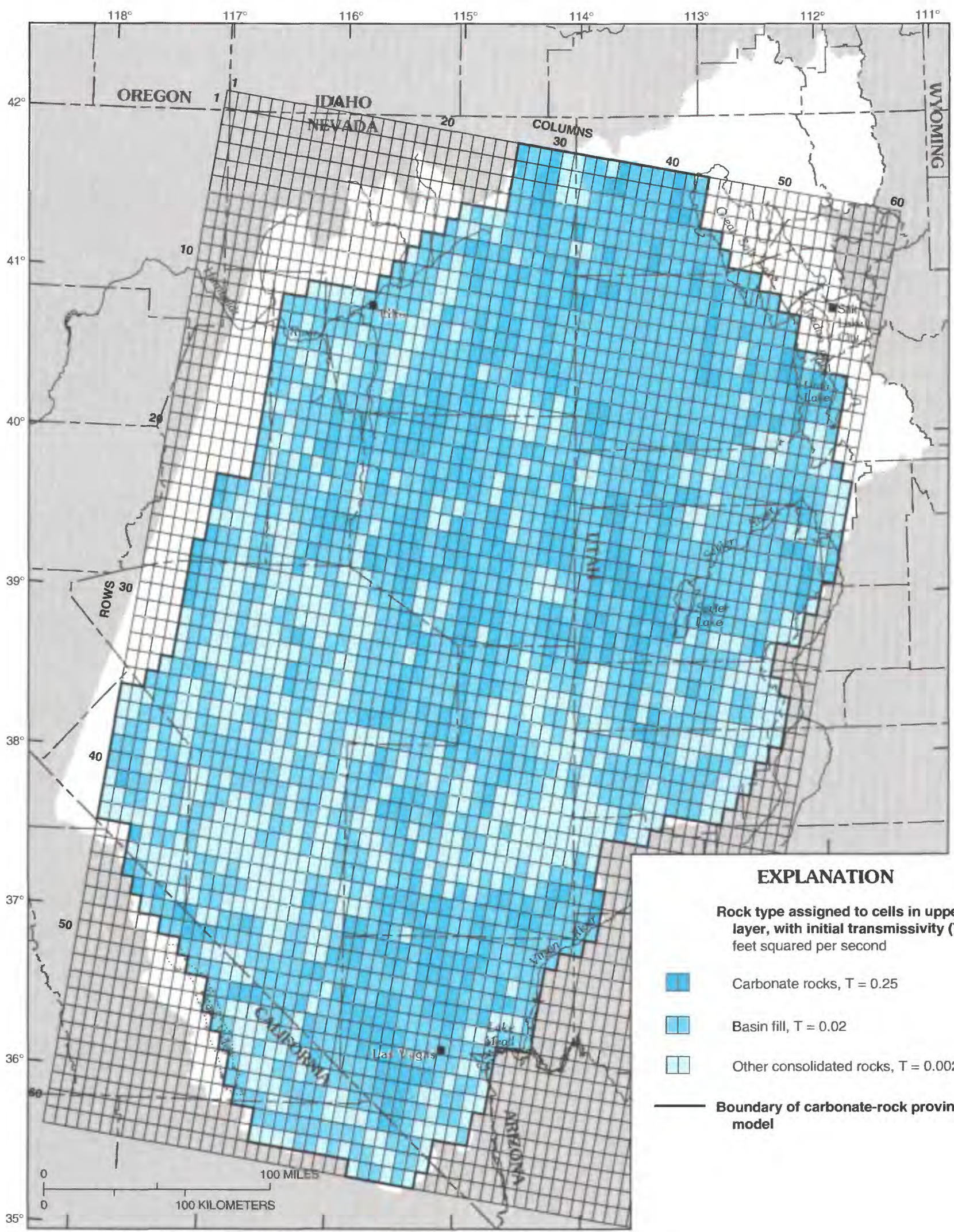

Rock type assigned to celis in upper model layer, with initial transmissivity (T) - In feet squared per second

Carbonate rocks, $\mathrm{T}=0.25$

Basin fill, $T=0.02$

Other consolidated rocks, $T=0.002$

Boundary of carbonate-rock province model

Base modified from U.S. Geological Survey digital linegraph data, 1:100,000 and 1:250,000, 1987 Albers Equal-Area Conic projection

Standard parallels $29^{\circ} 30^{\prime}$ and $45^{\circ} 30^{\prime}$, central meridian $-114^{\circ}$

Figure 15.-Principal rock types assigned to cells in upper model layer, and initial transmissivities used. 
computation because flow to and from a cell may change after adjusting the vertical leakance and the transmissivities in adjacent cells. Thus, the process involved numerous simulations that alternately adjusted transmissivities and vertical leakances. The use of these programs ceased once the simulated water levels over the entire model generally matched the water levels presented by Thomas and others (1986).

The final part of model calibration involved (1) testing the range in transmissivities and vertical leakances calculated from the initial calibration by comparing the simulated water levels in 773 selected cells in the upper layer and 144 cells in the lower layer where water levels had been estimated from the maps by Thomas and others (1986), (2) making regional and local changes to transmissivities and vertical leakances until simulated discharge as evapotranspiration in the upper model layer and regional spring flow in the lower layer approximated estimated values, and (3) adjusting conductance values at headdependent flow boundaries.

Transmissivities following the initial calibration ranged from $2.5 \times 10^{-4}$ to $2.5 \mathrm{ft}^{2} / \mathrm{s}$ in the upper layer and from $2.5 \times 10^{-4}$ to $2.5 \times 10^{-1} \mathrm{ft}^{2} / \mathrm{s}$ in the lower layer. During the final phase of model calibration, both transmissivities and vertical leakances were rounded to the nearest exponent $\left(1 \times 10^{-4} ; 1 \times 10^{-3} ; 1 \times 10^{-2}\right.$; and so forth) without affecting the simulation results. The rounding of both transmissivities and vertical leakances is reasonable because of the lack of information on the extent and distribution of aquifers, their hydraulic properties, and the lack of ground-water levels in many areas. Such groupings also simplified the final calibration while reasonably duplicating regional ground-water levels, and the distribution and quantity of discharge. The best match with estimated water levels and discharge was simulated when the grouped transmissivities were multiplied by a factor of 2.2 in the upper layer and when the values were multiplied by a factor of 3.3 in the lower layer. In a few areas, transmissivities were further multiplied by a factor ranging from 2 to 5 . Even though transmissivities are generally grouped by a factor of 10 , the range in simulated transmissivities did not change greatly from the initial calibration. In the upper layer, transmissivities following final calibration ranged from $2.2 \times 10^{-5}$ to $2.2 \times 10^{-1} \mathrm{ft}^{2} / \mathrm{s}$; both the minimum and maximum values are about 10 times less than the initially calibrated values. In the lower layer, transmissivities following model calibration ranged from $3.3 \times 10^{-5}$ to $6.6 \times 10^{-1}$ $\mathrm{ft}^{2} / \mathrm{s}$.

Vertical leakances following initial calibration ranged from $1 \times 10^{-16}$ to $3 \times 10^{-9}$ per second. During final calibration, increasing vertical leakances of less than $1 \times 10^{-13}$ to that value produced little difference in simulated water levels and discharge. Similarly, decreasing values greater than $1 \times 10^{-11}$ to that value also produced little differences. Finally, all other leakance values were rounded to values of $1 \times 10^{-11}, 1 \times 10^{-12}$, or $1 \times$ $10^{-13}$ per second. The distribution of vertical leakances is shown in figure 16 .

The average vertical leakance for all model cells is $4 \times 10^{-12}$ per second. Overall, 62 percent of cells $(1,517$ of 2,456$)$ have a value of $1 \times 10^{-12}$ per second, 34 percent ( 833 cells) have a value of $1 \times 10^{-11}$ per second, and only 4 percent (106 cells) have a value of $1 \times 10^{-13}$ per second. Most of the cells (95 out of 106) having the lowest vertical leakances are in or adjacent to the Great Salt Lake Desert. More than half of the cells having the highest leakances (455 out of 833 ) are in the central third of the modeled area (rows 21 to 40 ). In contrast, only 17 percent of the cells having the highest leakances (140 out of 833 ) are in the southern third of the modeled area (rows 41 to 61 ). In the central part, about half of the highest leakances correspond to mountain ranges, whereas in the southern third, 60 percent correspond to mountain ranges.

The magnitudes of the computed transmissivities and vertical leakances are dependent on the quantity of assigned recharge. Increasing recharge results in a corresponding increase in discharge and requires a proportional increase in transmissivities and vertical leakances to maintain the same head gradients. The estimates of recharge are only approximations; thus, recharge was increased by a factor of 2 and decreased by a factor of 2 during model calibration to evaluate its effect on transmissivities and vertical leakances.

Conductances used for the head-dependent flow boundaries range from 0.005 to $0.5 \mathrm{ft}^{2} / \mathrm{s}$ and average $0.13 \mathrm{ft}^{2} / \mathrm{s}$ for the 94 cells. Only one cell has a value of 0.005 , and three have a value of 0.5 . Conductances are slightly different between the different areas. Conductances for the Humboldt River range from 0.1 to $0.5 \mathrm{ft}^{2} / \mathrm{s}$ and average 0.24 $\mathrm{ft}^{2} / \mathrm{s}$; more than half of the cells (11 of 20) have a value of $0.3 \mathrm{ft}^{2} / \mathrm{s}$. Conductances for the Great Salt Lake and Utah Lake are $0.1 \mathrm{ft}^{2} / \mathrm{s}$, except for four cells along the Great Salt Lake, which 

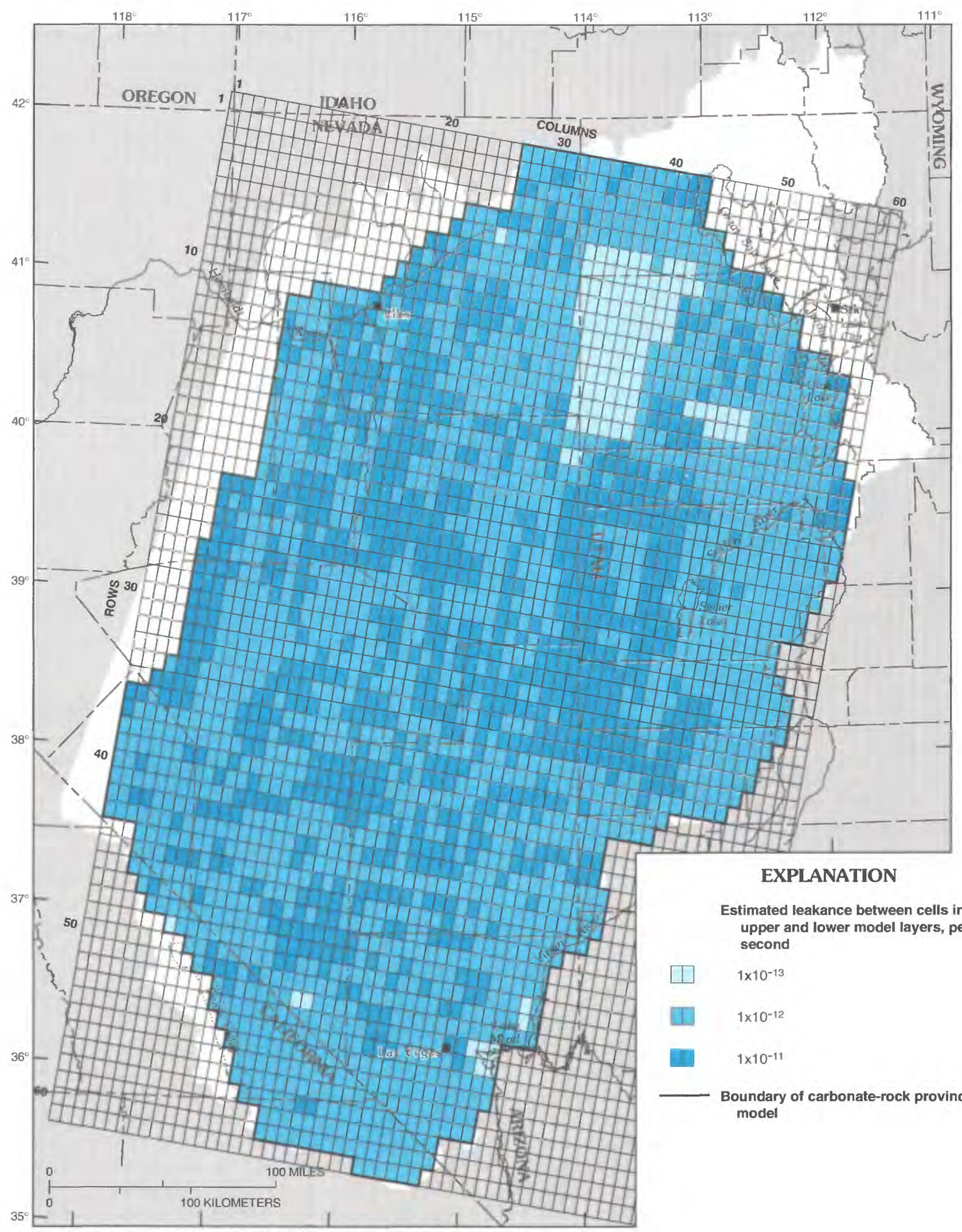

Estimated leakance between cells in upper and lower model layers, per second

$1 \times 10^{-13}$

$1 \times 10^{-12}$

$1 \times 10^{-11}$

Boundary of carbonate-rock province model

Base modified from U.S. Geological Survey digital linegraph data, 1:100,000 and 1:250,000, 1987 Albers Equal-Area Conic projection

Standard parallels $29^{\circ} 30^{\prime}$ and $45^{\circ} 30^{\prime}$, central meridian $-114^{\circ}$

Figure 16.-Estimated vertical leakance between cells in upper and lower model layers. 
have a value of 0.15 . Conductances range from $0.01 \mathrm{ft}^{2} / \mathrm{s}$ for the upstream reaches of the Sevier River to 0.15 for Sevier Lake; conductances for the Sevier River average $0.07 \mathrm{ft}^{2} / \mathrm{s}$. Conductances for the Virgin River are $0.01 \mathrm{ft}^{2} / \mathrm{s}$, except for the northernmost cell, which is $0.02 \mathrm{ft}^{2} / \mathrm{s}$. Conductances for Lake Mead are also $0.01 \mathrm{ft}^{2} / \mathrm{s}$, except for the two cells nearest the dam, which are $0.5 \mathrm{ft}^{2} / \mathrm{s}$. The conductance for the one cell representing the Colorado River below the dam is $0.005 \mathrm{ft}^{2} / \mathrm{s}$. Conductances for Death Valley are $0.1 \mathrm{ft}^{2} / \mathrm{s}$.

Because flow to and from the head-dependent boundaries are generally controlled by the estimated transmissivities of the model cells, changing conductances does not greatly affect the simulation results. For example, decreasing the conductances for cells that have a value of 0.5 $\mathrm{ft}^{2} / \mathrm{s}$ to $0.1 \mathrm{ft}^{2} / \mathrm{s}$ resulted in a slight decrease $(0.1$ $\mathrm{ft}^{3} / \mathrm{s}$ ) in discharge and recharge along the Humboldt River and no change to discharge at Lake Mead. Increasing the conductances for nine cells along the Sevier River which had values less than $0.1 \mathrm{ft}^{2} / \mathrm{s}$ by a factor of 10 resulted in a 10 percent increase in discharge $\left(5 \mathrm{ft}^{3} / \mathrm{s}\right.$ increase) to the Sevier River, a corresponding decrease in simulated evapotranspiration, and consequently, no change in the simulated discharge from the area.

Total simulated spring discharge from the lower model layer is only 0.5 percent greater than the total estimated discharge (table 1). However, the percentage difference between simulated and estimated discharge for individual springs is generally more. For example, simulated discharge at Warm Springs (table 1) is 152 percent of the estimated discharge.

During final model calibration, conductance values used to simulate spring discharge were changed to test their sensitivity. Initially, a uniform value of $3 \mathrm{ft}^{2} / \mathrm{s}$ was assigned to each spring. This value is more than two orders of magnitude greater than the initial conductance value assigned between layers (vertical leakance multiplied by cell area). Increasing the conductance value for springs to $10 \mathrm{ft}^{2} / \mathrm{s}$ did not affect discharge from the lower layer, indicating that the discharge was dependent on flow from adjacent model cells. The higher conductance values resulted in slightly reduced water levels in cells where spring discharge was simulated, because not as much head difference was needed to simulate flow through the springs. A value of $10 \mathrm{ft}^{2} / \mathrm{s}$ was used during final model calibration. Spring discharge was extremely sensitive to changes in both transmissivity and vertical leakance.
Land-surface altitude assigned to each model cell in the upper layer controlled the distribution of evapotranspiration and water levels in cells where evapotranspiration was simulated. Initially, land-surface altitudes assigned to each cell were averaged values. This did not produce a reasonable distribution of evapotranspiration and water levels in some areas of the model. Adjusting transmissivities and vertical leakances did not always improve results. Areas of evapotranspiration are generally confined to the lowest parts of a valley. Consequently, minimum land-surface altitudes from the one-minute data were used in areas of known evapotranspiration.

Because evapotranspiration did not reach a maximum rate when water levels exceeded land surface (fig. 10B), simulated water levels in cells with evapotranspiration were compared with the assigned land-surface altitude. Whenever water levels exceeded land surface, transmissivity and leakance values in that cell, and sometimes in surrounding cells, were changed to lower heads below land surface. Evapotranspiration of ground water was assumed to occur only from basin fill in the valley lowlands. Thus, the transmissivity and leakance values were increased in a model cell corresponding to consolidated rocks whenever evapotranspiration was simulated in such a cell. Final distribution of simulated evapotranspiration is shown in figure 17. The simulated distribution generally corresponds to areas mapped by Harrill and others (1988, pl. 2). Areas mapped by Harrill and others are shown in figure 18.

The model was deemed calibrated when simulated discharge approximated the mapped distribution and estimated discharge in each hydrographic area. In addition, computed water levels were matched as closely as practical with estimated values. For the best-fit simulation, 86 percent of the simulated water levels (666 out of 773 model cells) were within $250 \mathrm{ft}$ of the estimated water levels for the upper layer and 76 percent (109 out of 144 cells) were within $250 \mathrm{ft}$ for the lower layer.

The 250-ft criterion used for calibration purposes is only 3 percent of the total water-level difference in the model. The maximum simulated water level is more than $7,000 \mathrm{ft}$ above sea level, along the eastern side of the model; in contrast, the minimum is below sea level, in Death Valley. Water-level differences between adjacent model cells commonly exceed $250 \mathrm{ft}$; in a few locations, they exceed $500 \mathrm{ft}$. The distribution of water levels in both model layers for the best-fit calibration is shown in figure 19 . 


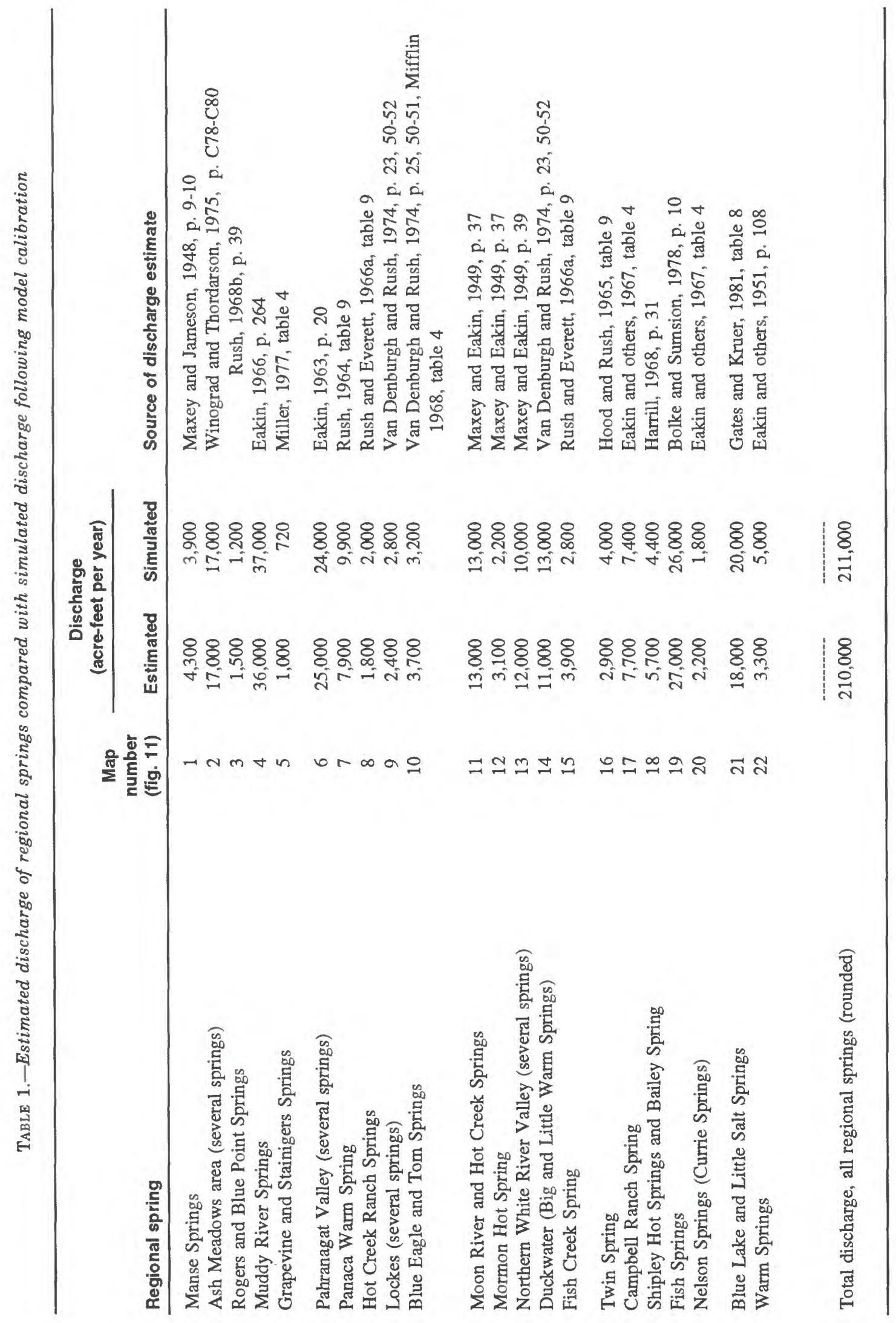



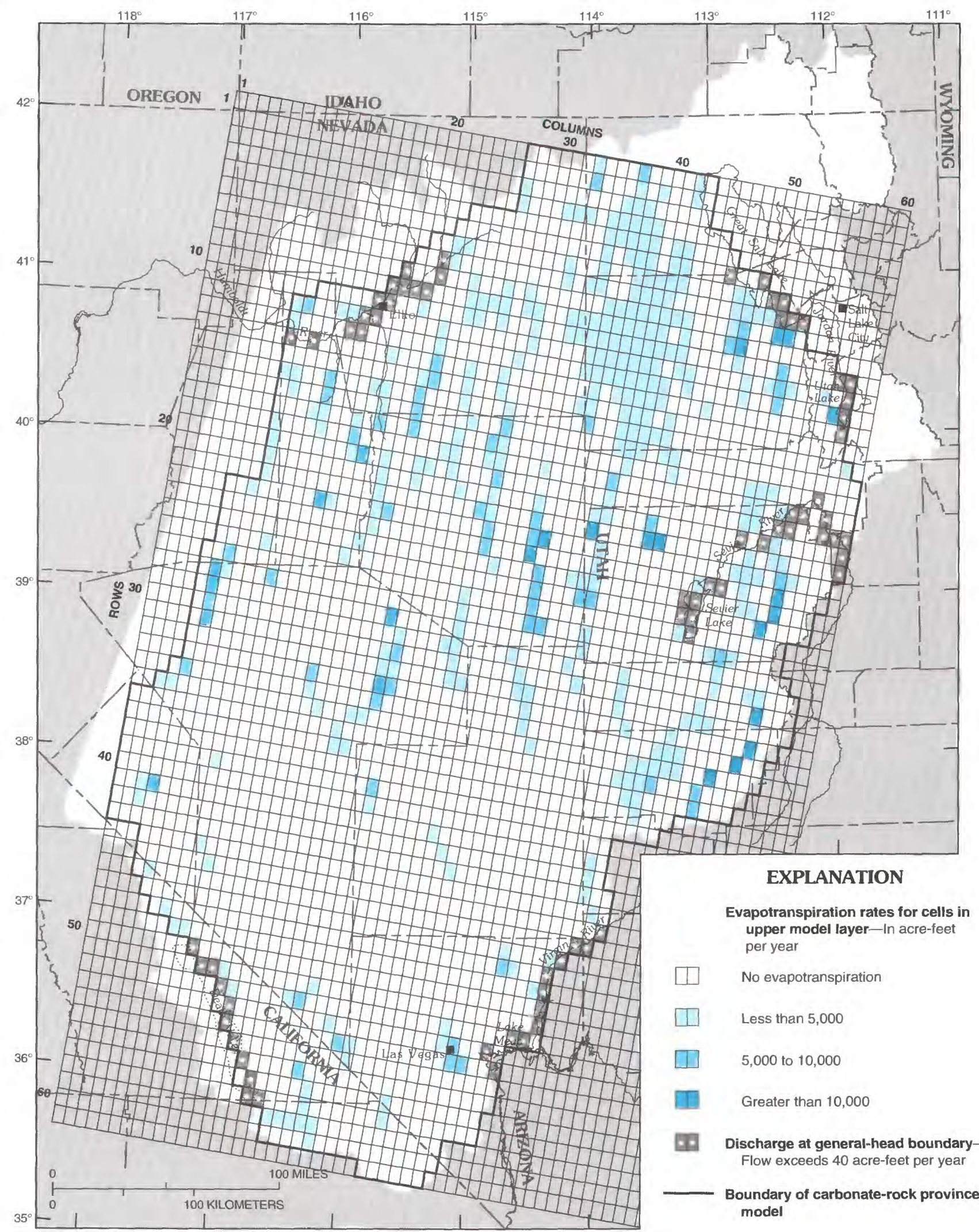

EXPLANATION

Evapotranspiration rates for cells in upper model layer-In acre-feet per year

No evapotranspiration

Less than 5,000

5,000 to 10,000

Greater than 10,000

Discharge at general-head boundaryFlow exceeds 40 acre-feet per year

Base modified from U.S. Geological Survey digital linegraph data, 1:100,000 and 1:250,000, 1987

Albers Equal-Area Conic projection

Standard parallels $29^{\circ} 30^{\prime}$ and $45^{\circ} 30^{\prime}$, central meridian $-114^{\circ}$

Figure 17.-Simulated evapotranspiration rates in cells in upper model layer, and simulated discharge from rivers, lakes, and Death Valley through general-head boundaries. 


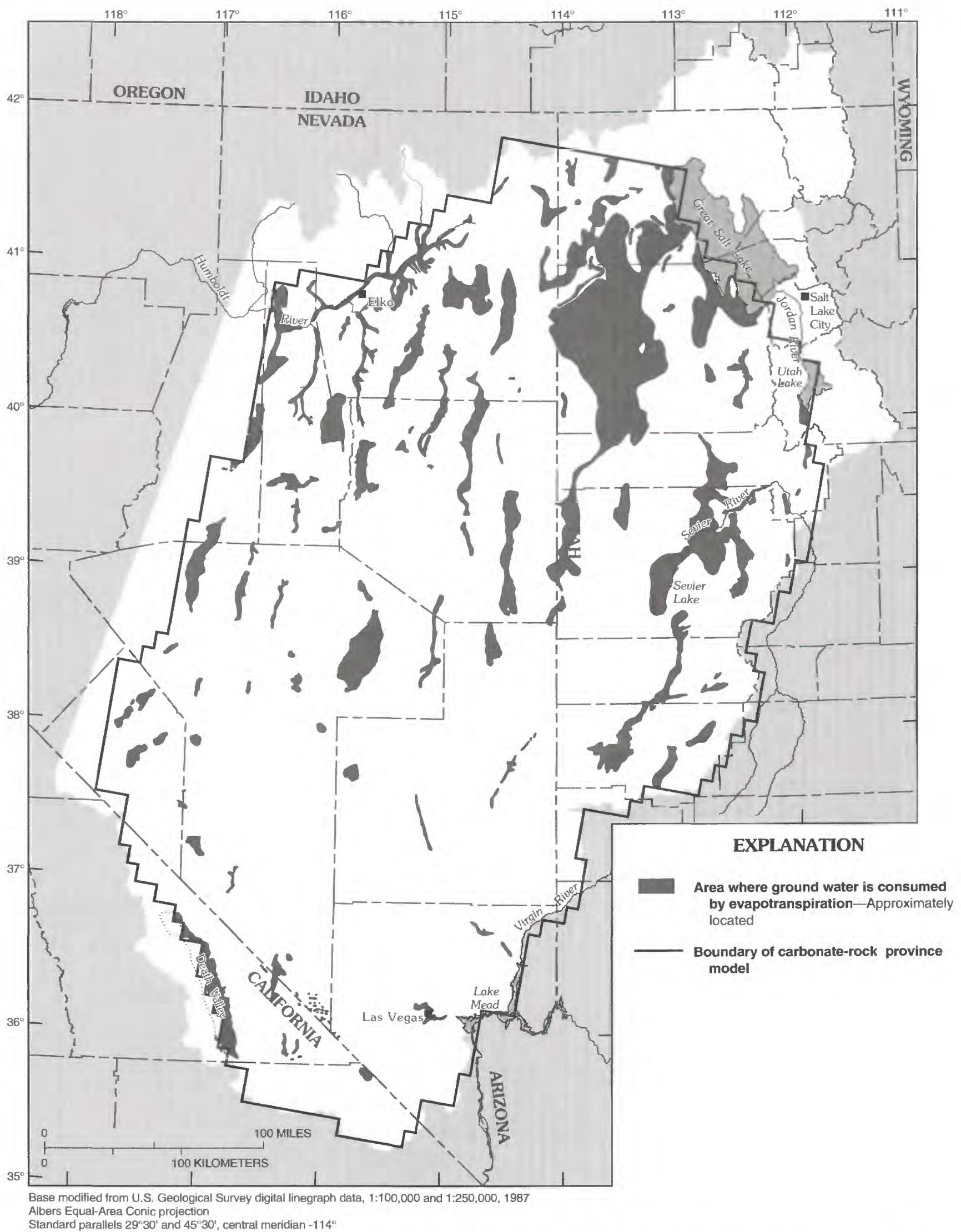

FIGURE 18.-Areas where ground water is consumed by evapotranspiration ( from Harrill and others, 1988, pl. 2). 


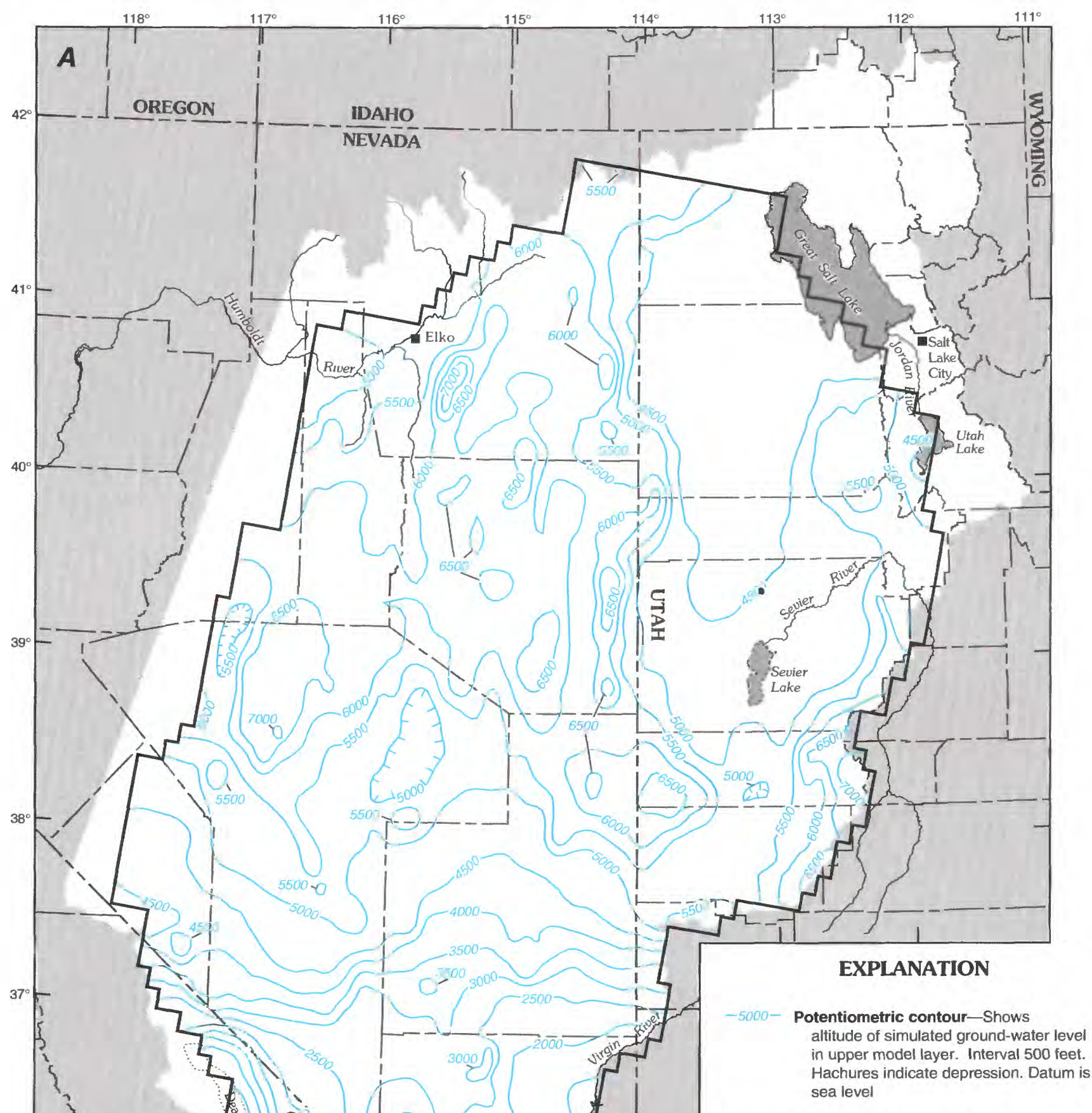

Boundary of carbonate-rock province model

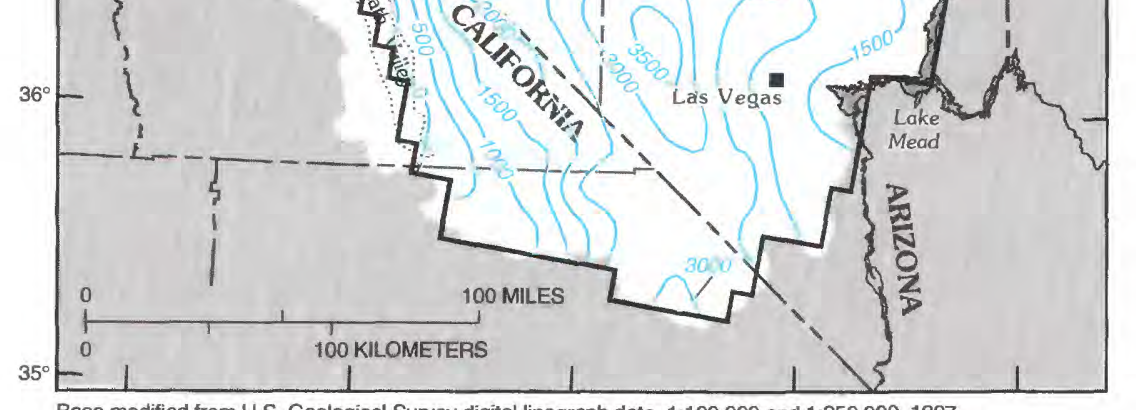

Base modified from U.S. Geological Survey digital linegraph data, 1:100,000 and 1:250,000, 1987

Albers Equal-Area Conic projection

Standard parallels $29^{\circ} 30^{\prime}$ and $45^{\circ} 30^{\prime}$, central meridian $-114^{\circ}$

Figure 19.-Simulated steady-state ground-water levels. A, Upper model layer. B, Lower model layer. 


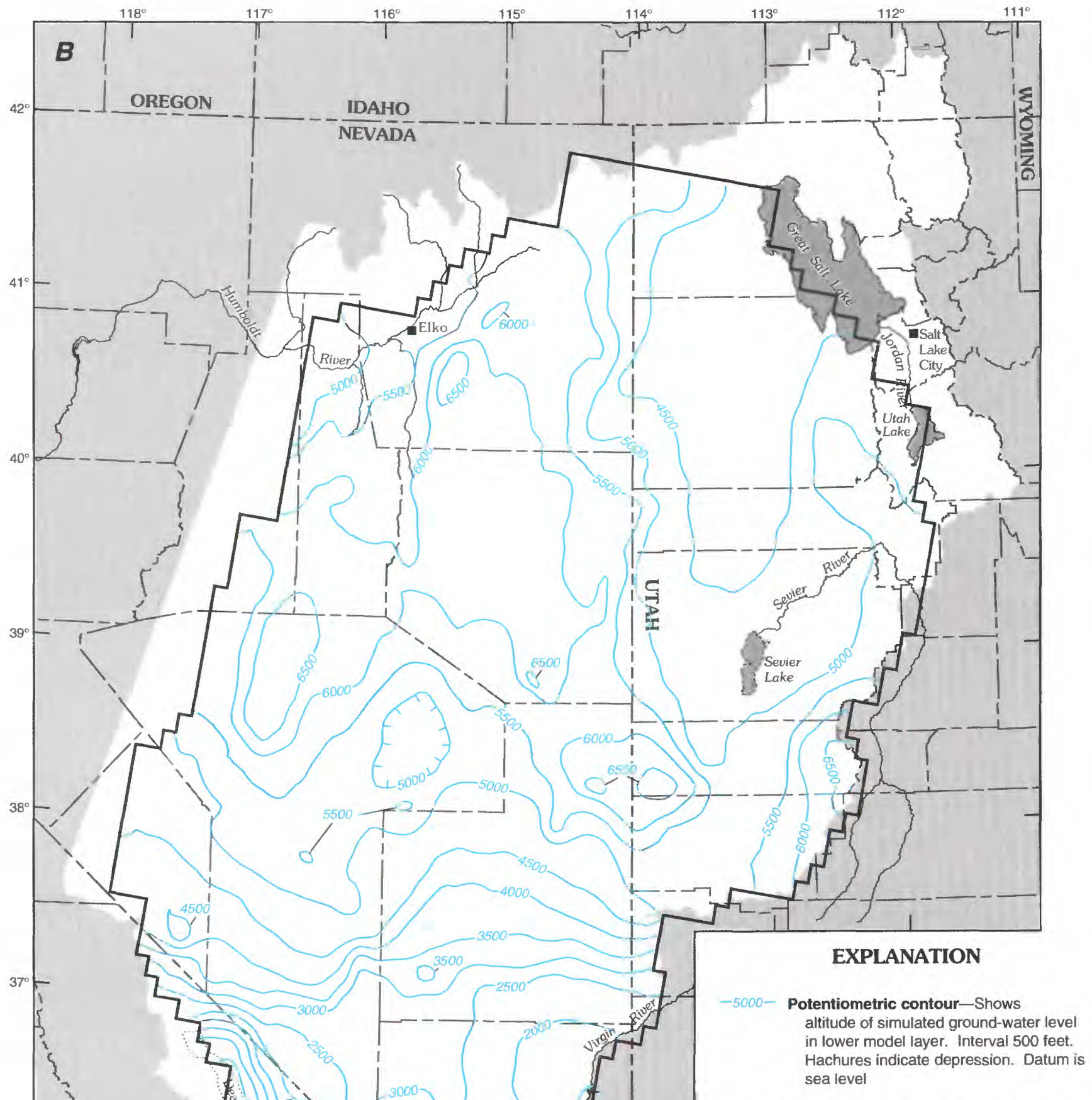

Boundary of carbonate-rock province model

$35^{\circ}$

Base modified from U.S. Geological Survey digital linegraph data, 1:100,000 and 1:250,000, 1987 Albers Equal-Area Conic projection

Standard parallels $29^{\circ} 30^{\prime}$ and $45^{\circ} 30^{\prime}$, central meridian $-114^{\circ}$

Figure 19.-Continued. 
Conductance values used to simulate the interaction of ground water with surface water (general-head boundaries in fig. 9) were changed during model calibration until the simulated water-level gradients near the boundaries approximated the estimated gradients.

\section{LIMITS OF CALIBRATION}

Results from the model simulation are only approximate because uncertainties exist in the distribution and quantity of recharge and because water levels in the consolidated rocks are unknown over much of the area. Although discussed in detail, the model results are conceptual because actual values are not known for any of the variables in the ground-water flow equation. In particular, other, equally valid, distributions of transmissivity may be found that permit the model to be calibrated to the existing information. Model results are also dependent on the general assumptions discussed previously.

Transmissivities estimated for both model layers are in part dependent on the quantity and distribution of recharge used in the model, particularly for model cells that correspond to mountains. Recharge is simulated in the mountains except where head-dependent flow boundaries are used to simulate the interaction of ground water with surface water. Simulating all recharge in mountains that consist of carbonate rocks is probably reasonable because little surface water flows to the nearby valleys. But in mountains that consist of low-permeability rocks, much of the water flows into nearby valleys where recharge occurs mostly on the adjacent alluvial fans. Thus, the transmissivities estimated for model cells that represent these mountains are probably higher than the actual transmissivities.

Transmissivities in the upper model layer are highly sensitive to changes in both the quantity and location of recharge. Transmissivities for the lower model layer are not as sensitive to changes in recharge, because recharge is not added directly to cells in this layer. Recharge to the lower layer is dependent on the leakage between the upper and lower layers, which is controlled by the vertical leakance.

Errors in the estimates of recharge are unknown but locally could be well in excess of 100 percent. If recharge is increased in the model by
100 percent, a similar distribution of water levels could be simulated by proportionately increasing transmissivities and vertical leakances. Because the model assumes steady-state conditions, discharge would also increase by 100 percent. However, a different distribution of transmissivity and vertical leakance near regional springs would be needed if the additional recharge was forced to discharge as evapotranspiration instead of allowing spring discharge to increase as well.

Estimates of water levels used to calibrate transmissivities in the lower model layer are based on limited data. Locally, transmissivities could be changed an order of magnitude, and model results might still be reasonable with respect to areas of estimated water levels and quantities of simulated discharge. Large cell sizes and the generalization of transmissivities result in a more gradual change in simulated water levels than might be expected from abrupt lateral and vertical changes in geologic units observed in the study area. Where geologic structures are barriers to flow in south-central Nevada, water-level differences between adjacent valleys are as much as $2,000 \mathrm{ft}$ (Winograd and Thordarson, 1975, p. 63). With cell sizes of $5 \mathrm{mi}$ by $7.5 \mathrm{mi}$, the model tends to smooth such large differences.

The model is designed to simulate groundwater flow at a regional scale. Orientation of the columns in the model grid corresponds to the general trend of range-front faults. These faults are thus parallel and perpendicular to the two directions of horizontal transmissivity. However, rangefront faults are not the only faults present in the province. The mountains are extensively faulted, as presumably are the rocks beneath the basin fill. Orientation of the model grid to coincide with the range-front faults therefore may be unnecessary. Also, transmissivity in one of the two principal directions could be changed with respect to the other direction over the entire modeled area, although no compelling reason was discovered to simulate such a condition. Anisotropy probably exists on a more localized scale, but available computer programs do not allow anisotropy to be specified by individual model cells. Localized anisotropic conditions could be simulated by reducing the dimensions of the model cells. The simulation of ground-water flow with smaller cell dimensions is not beyond the scope of this study. However, insufficient data over large areas preclude such a detailed simulation. 


\section{SIMULATION RESULTS}

Discussion of the simulation results has been divided into three sections: (1) estimated transmissivities, (2) correlation of ground-water flow to regional geologic features, and (3) distribution of flow into regions.

\section{ESTIMATED TRANSMISSIVITIES}

Transmissivities in both model layers were estimated by adjusting the initial values until simulated water levels generally agreed with estimated water levels and the quantity and distribution of simulated discharge approximated those of the estimated discharge. The transmissivities are also dependent on the quantity and distribution of recharge assigned to cells corresponding to mountain ranges. Estimated transmissivities for the upper and lower model layers are shown in figure 20.

Errors in transmissivities are unknown, but the estimates could be off by a factor of 5 or more. Other uncertainties used in the model also result in unknown errors, especially the assumption of isotropy in each $37.5-\mathrm{mi}^{2}$ model cell in an area of complex geology. Consequently, transmissivities are discussed using the qualitative terms listed as follows:

$\begin{array}{lc}\begin{array}{c}\text { Qualitative } \\ \text { term }\end{array} & \begin{array}{c}\text { Transmissivity range } \\ \text { (feet squared per second) }\end{array} \\ \text { Lowest ......................... } & <0.0006 \\ \text { Low ............................... } & 0.0006-0.006 \\ \text { High .............................. } & 0.006-0.18 \\ \text { Highest ........................... } & 0.18-0.66\end{array}$

In the upper model layer, no distinct pattern of transmissivities is simulated (fig. 20A), perhaps because of areal variability in the quantity and distribution of recharge. Highest transmissivities are scattered in small groups of cells throughout much of the province. Lowest transmissivities are concentrated in the Great Salt Lake Desert, in the vicinity of Death Valley, and in the extreme southern part of the province. Low values are assigned in the Great Salt Lake Desert to match estimated ground-water discharge. Circulation of fresh ground water in this area is assumed minimal because the area is underlain by an extensive body of saline ground water. Low values are assigned in the vicinity of Death Val- ley and in the southern part of the province to simulate large hydraulic gradients between Death Valley and adjacent basins. Outcrops of Cambrian and Precambrian clastic rocks, assumed to be poorly permeable, are common in the mountains surrounding Death Valley.

In the lower model layer, high transmissivities are generally grouped in areas associated with regional springs or in the vicinity of basins where ground-water discharge is considerably more than the estimated recharge from tributary drainage areas (fig. 20B). Highest values are simulated in narrow bands near regional springs in the White River Valley in eastern Nevada, near the Muddy River Springs area in southern Nevada, and near Fish Springs in west-central Utah. Elsewhere in the province, low transmissivities are simulated. Lowest transmissivities are simulated in the Great Salt Lake Desert, Death Valley, and the extreme southern end of the province, with an areal distribution similar to that of the upper layer.

Transmissivities in the upper and lower model layers are summarized in table 2.

The geometric mean transmissivity of the upper layer is greater than that of the lower layer even though the minimum, median, and maximum values in the upper layer are less than those in the lower layer. However, the 25th-and 75th-percentile values are nearly an order of magnitude greater in the upper layer. The reason for this seeming disparity is that the estimated transmissivities in the model cells are assigned values that generally differ by an order of magnitude. In the upper layer, about 40 percent of the active cells (979 of 2,456 cells) are assigned an estimated transmissivity of $0.022 \mathrm{ft}^{2} / \mathrm{s}$, whereas in the lower layer approximately half of the active cells $(1,187$ of 2,456 cells) are assigned an estimated transmissivity of $0.0033 \mathrm{ft}^{2} / \mathrm{s}$.

As a result of model calibration, estimated transmissivities in both model layers are generally less than the initially assigned values. Initially, one of three transmissivity values was assigned to groups of model cells in the upper layer on the basis of surficial geology (that is, carbonate rocks, basin fill, or consolidated rocks of low permeability; fig. 15), and one value representing carbonate rocks was assigned to all cells in the lower layer. The frequency distribution of estimated transmissivities for the three groups of rocks in the upper layer is shown in figure 21. Also shown is the frequency distribution for 

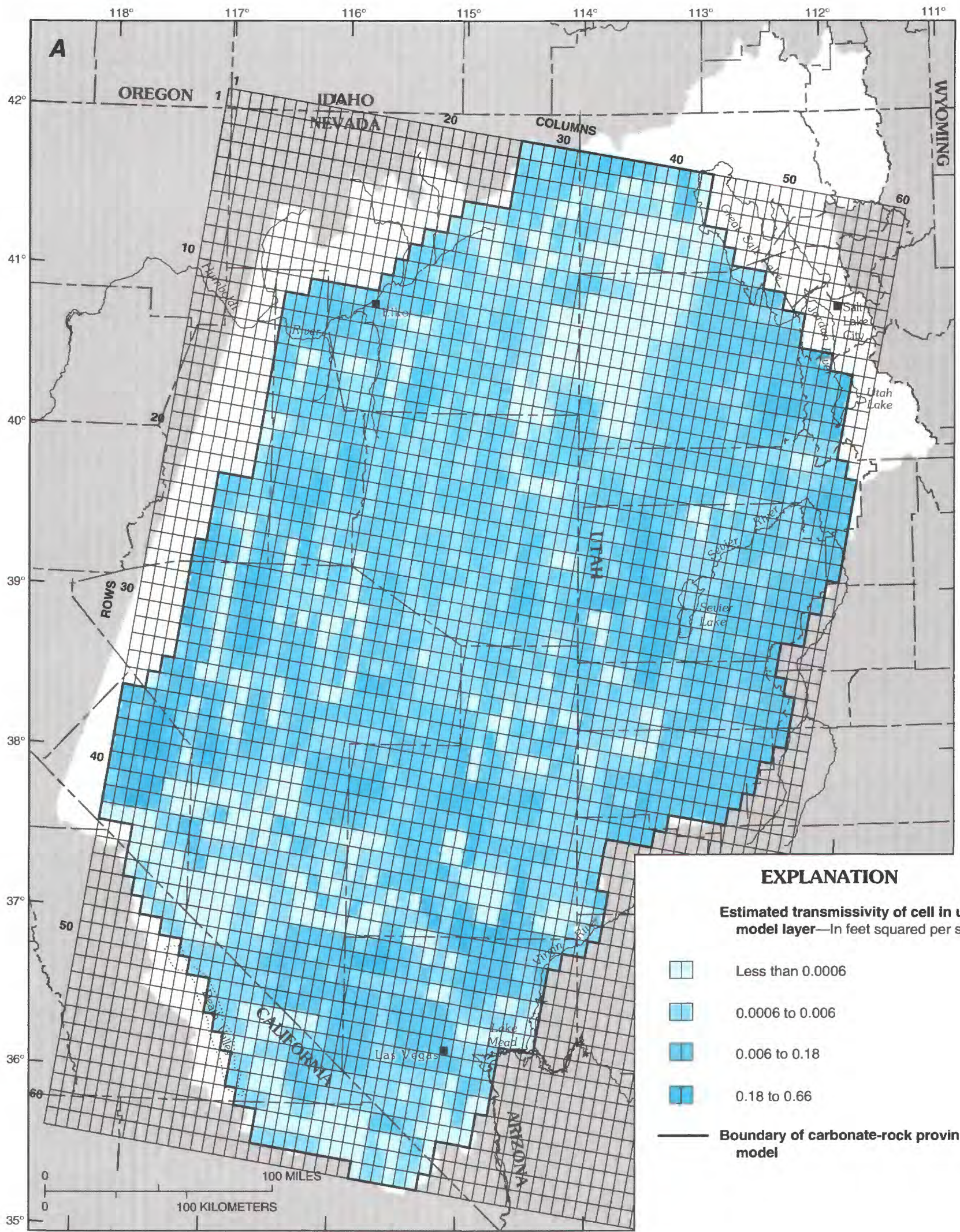

Estimated transmissivity of cell in upper model layer-In feet squared per second

Less than 0.0006

0.0006 to 0.006

0.006 to 0.18

0.18 to 0.66

Base modified from U.S. Geological Survey digital linegraph data, 1:100,000 and 1:250,000, 1987 Albers Equal-Area Conic projection

Standard parallels $29^{\circ} 30^{\prime}$ and $45^{\circ} 30^{\prime}$, central meridian $-114^{\circ}$

FIGURe 20.-Estimated transmissivities. $A$, Upper model layer. $B$, Lower model layer. 

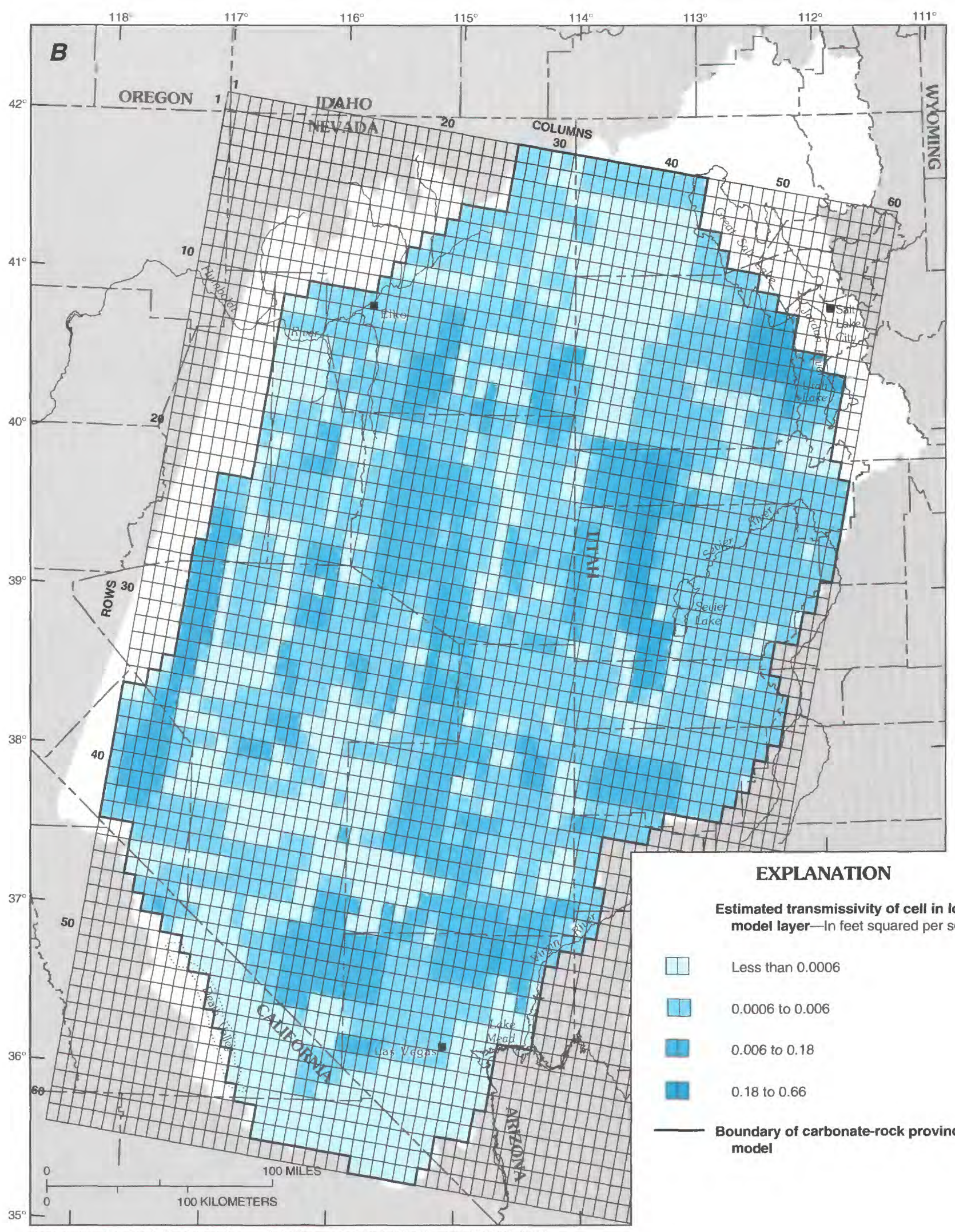

EXPLANATION

Estimated transmissivity of cell in lower model layer-In feet squared per second

Less than 0.0006

0.0006 to 0.006

0.006 to 0.18

0.18 to 0.66

Boundary of carbonate-rock province model

Base modified from U.S. Geological Survey digital linegraph data, 1:100,000 and 1:250,000, 1987 Standard parallels $29^{\circ} 30^{\prime}$ and $45^{\circ} 30^{\prime}$, central meridian $-114^{\circ}$

Figure 20.-Continued. 
TABLE 2.-Selected statistics of estimated transmissivities in both model layers

\begin{tabular}{lccccccc}
\hline & & \multicolumn{5}{c}{ Transmissivity (feet squared per second) } \\
\cline { 3 - 8 } $\begin{array}{l}\text { Model } \\
\text { layer }\end{array}$ & $\begin{array}{c}\text { Number of } \\
\text { cells }\end{array}$ & $\begin{array}{c}\text { Geometric } \\
\text { mean }\end{array}$ & Minimum & $\begin{array}{c}\text { 25th } \\
\text { percentile }\end{array}$ & Median & $\begin{array}{c}\text { 75th } \\
\text { percentile }\end{array}$ & Maximum \\
\hline Upper & 2,456 & 0.0048 & 0.000022 & 0.0022 & 0.0022 & 0.022 & 0.22 \\
Lower & 2,456 & .0030 & .000033 & .00033 & .0033 & .0033 & .66 \\
\hline
\end{tabular}

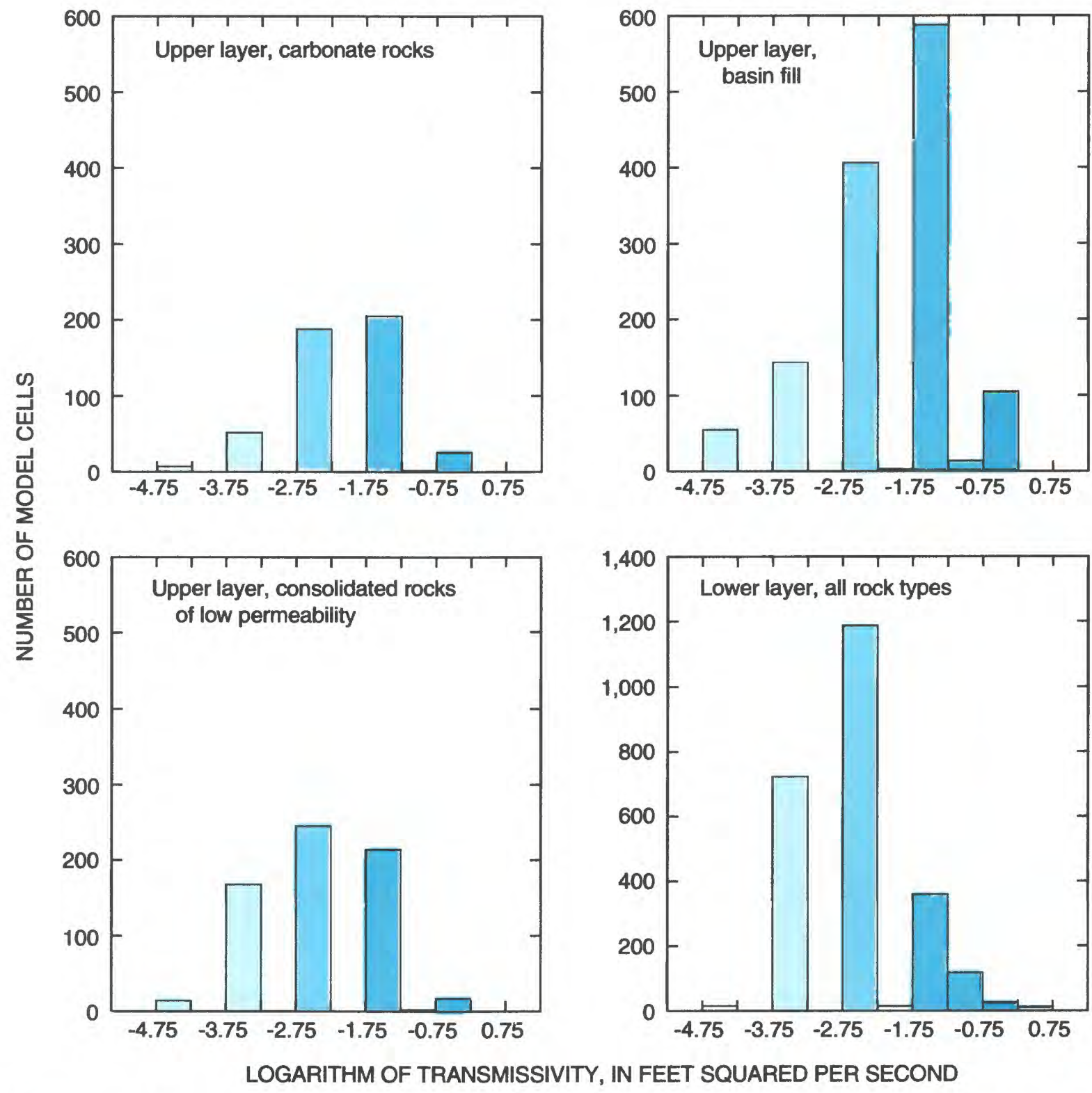

Figure 21.-Frequency distributions of estimated transmissivities for cells in upper model layer on basis of principal rock type, and for all cells in lower model layer. Shades correspond to transmissivity ranges in figure 20 . 
TABLE 3.-Summary of estimated transmissivities for model cells corresponding to selected rock types in both model layers

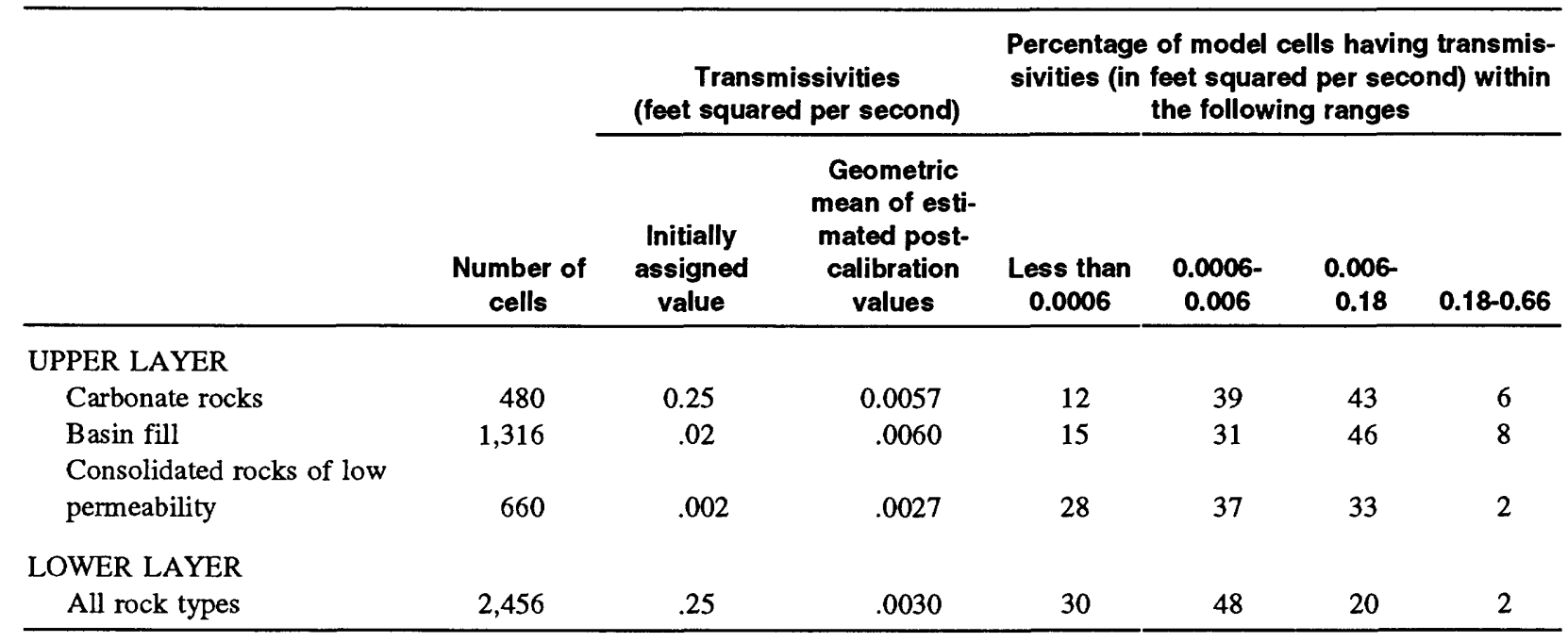

all rock types (all model cells) in the lower layer. Estimated transmissivities for each group of rocks are log-normal distributions. The geometric mean transmissivities for each group of rocks in the upper layer and all rock types in the lower layer, and the percentage of model cells within the transmissivity ranges shown in figure 20 , are listed in table 3.

The geometric means of estimated transmissivities for cells representing carbonate rocks and basin fill are only 3 and 30 percent, respectively, of the initially assigned values $\left(0.25\right.$ and $\left.0.02 \mathrm{ft}^{2} / \mathrm{s}\right)$, whereas the geometric mean for cells representing consolidated rocks of low permeability is 135 percent of the initially assigned value. The geometric mean of estimated transmissivities for all rock types in the lower layer is only 1 percent of the initially assigned value. Overall, this mean closely approximates the geometric mean for cells representing consolidated rocks of low permeability, rather than that of carbonate rocks.

In the upper model layer, the distribution of estimated transmissivities for cells representing carbonate rocks and basin fill are nearly the same (table 3). In contrast, a greater percentage of cells representing consolidated rocks of low permeability have an estimated transmissivity of less than $0.0006 \mathrm{ft}^{2} / \mathrm{s}$ (28 percent compared with 12 and 15 percent for cells representing carbonate rocks and basin fill, respectively). In the lower model layer, the distribution of estimated transmissivities for all cells is similar to the distribution for cells representing consolidated rocks of low permeability in the upper layer, except that the lower layer has a greater percentage of cells with estimated transmissivities of less than $0.006 \mathrm{ft}^{2} / \mathrm{s}(78$ percent compared with 65 percent for cells representing consolidated rocks of low permeability).

\section{CORRELATION OF SIMULATED GROUND- WATER FLOW TO REGIONAL GEOLOGIC FEATURES}

The most striking geologic structures in the study area are the normal faults that separate the basins and mountains. These faults are the result of extension that has been occurring over the past 17 million years. Normal faulting (mainly the juxtaposition of basin fill and consolidated rocks) is indirectly incorporated in the model, because columns in the grid are oriented parallel to the general strike of the mountain ranges and adjacent basins. Thus, differences in transmissivities between cells representing basin fill and consolidated rocks may indirectly simulate the effects of these normal faults on ground-water flow.

Faults may provide vertical conduits for flow or act as barriers to horizontal flow by offsetting permeable rocks against low-permeability rocks. Discontinuities in rock types along a fault would cause a marked change in the hydraulic gradient across the fault (referred to as fault compartmentalization by Winograd and Thordarson, 1975, p. 119). In addition, broken rock adjacent to faults could act as a conduit if the rubble is porous and not cemented, but could act as a barrier if the rocks are highly cemented. The model simulates average transmissivities and water levels for each cell, thus water-level or permeability changes due to faults within a cell cannot be represented. However, a step function of water-level change can 
be simulated across model-cell boundaries whenever adjacent cells have different transmissivities. Unfortunately, such changes can be masked because water levels for each model layer are contoured using an averaging technique that draws contours on the basis of a linear interpolation of water levels between adjacent model cells and because the large contour intervals $(500 \mathrm{ft}$ ) were chosen to show regional trends. Thus, marked changes in water levels between individual cells are generally not evident.

Several east-west-trending lineaments that generally are at right angles to the north- to northeast-trending normal faults have been discussed in the literature (Roberts, 1964, 1966; Eaton, 1975; Stewart and others, 1975, 1977; Ekren and others, 1976; Rowley and others, 1978; Rowan and Wetlaufer, 1981). These lineaments are usually several tens of miles to a hundred miles long and one to several miles wide. The lineaments tend to be associated with disruption and termination of mountain ranges, stratigraphic discontinuities, east- to east-northeast-trending faults, mineral belts, caldera boundaries, volcanic deposits, and changes in both gravity and aeromagnetic gradients. Rowan and Wetlaufer $(1981$, p. 1414) proposed that the east-west lineaments are conjugate shears formed during and after middle Miocene extension. Ekren and others (1976, p. 1) suggest that the east-west lineaments are caused by deepseated crustal control. However, they are uncertain whether the lineaments are partly the result of conjugate shears or are caused by a continentwide fracture system.

Stewart and others (1977, p. 67) noted that the Cenozoic igneous rocks crop out in generally east-west-trending belts and that the rocks become successively younger southwestward. The oldest igneous rocks are about 34 to 43 million years old near latitude $40^{\circ}$, and the youngest rocks are about 6 to 17 million years old along an eastwest belt near latitude $37^{\circ}$. They postulated that the volcanic front is related to igneous activity localized along a southward propagating transverse break or structural warp in a subducting plate. A similar conclusion was reached by Ekren and others (1976, p. 15), but they also noted that the faulting along the lineaments became younger toward the west and southwest ends, which agrees with a southwestward decrease in the age of silicic volcanism.

The east-west lineaments could act as barriers to ground-water flow because the features usually extend across many tens of miles to a hundred miles, are several miles wide, and may disrupt the continuity of Paleozoic carbonate rocks by the repositioning of less permeable intrusive and (or) extrusive rocks, or by movement along left-lateral strike-slip faults. The lineaments are shown superimposed on the simulated water levels in the upper and lower model layers in figure 22 . One lineament, the Oregon-Nevada lineament described by Stewart and others (1975), trends in a northwesterly direction essentially parallel to the Walker belt, a zone of right-lateral shears. The Oregon-Nevada lineament (also referred to as the Cortez rift) is characterized by a northnorthwest-trending belt of closely spaced faults, centers of volcanic activity during the late Miocene, and a conspicuous aeromagnetic anomaly. Also shown in figure 22 are reported metamorphic core complexes and east-west-trending mineral belts.

Of the lineaments in figure 22 , only the transverse crustal boundary of Eaton (1975) corresponds to a change in simulated water levels. Water levels decrease southward, suggesting southward flow across the lineament. Near the lineament, the simulated water-level gradient ranges from about $40 \mathrm{ft} / \mathrm{mi}$ in the central part to $200 \mathrm{ft} / \mathrm{mi}$ at the western end and near Death Valley. South of the lineament, the water-level gradient generally decreases in the central part; the gradient from the boundary to Ash Meadows is about $20 \mathrm{ft} / \mathrm{mi}$. The lineament is nearly coincident to the axis of the southern part of the intermountain seismic belt (Rowley and others, 1978) and generally marks the southern limit of Cenozoic igneous activity. The lineament is also coincident with a considerable decrease in altitude of the valley floors; north of the lineament, valley floors are generally $4,000 \mathrm{ft}$ or more above sea level, whereas south of the lineament, valley floors are $2,000 \mathrm{ft}$ or less above sea level. Water levels in the basin fill generally follow changes in land-surface altitudes of the valley floors. Except for a relatively narrow band of high transmissivities in east-central Nevada, low transmissivities are estimated along the lineament (fig. 20).

The other lineaments shown in figure 22 do not correspond as well as the transverse crustal boundary to changes in simulated water levels, although many of the regional springs (discharge points in the lower model layer shown in fig. 22B) may be controlled at least in part by structures related to the lineaments. Transmissivities (fig. 20) are generally lower in model cells that correspond to lineaments, although there is no con- 
sistent pattern. The Oregon-Nevada lineament (feature 6 in fig. $22 B$ ) corresponds to a discontinuous zone of low transmissivities in the lower model layer (compare figs. $20 B$ and $22 B$ ). This lineament also corresponds to springs and areas of phreatophytes where ground water is near land surface.

The Warm Springs lineament in Nevada (feature 1 in fig. $22 B$ ) and the Blue Ribbon lineament (feature 5 in fig. $22 B$ ) generally cut across the study area at latitude $38^{\circ}$. The Blue Ribbon lineament in Utah is associated with the Pioche mineral belt, which has abundant volcanic deposits that are elongate in an east-west direction (Stewart and others, 1977; Rowley and others, 1978 , p. 180), and generally corresponds with a ground-water divide between northward flow toward the Great Salt Lake Desert and southward flow toward the Virgin River and Lake Mead.

The lack of pronounced changes in simulated water levels, and transmissivities along the lineaments north of the transverse crustal boundary could be due to younger normal faults disrupting the lineaments. Accordingly, the older lineaments may be leaky barriers to ground-water flow. In contrast, igneous activity along the transverse crustal boundary began at about the same time as the normal faulting. Perhaps the structures and emplaced intrusions along this lineament have not been disrupted, so structures along the lineament still act as barriers to flow.

Some structures that might affect ground-water flow could not be correlated with the simulated water levels and transmissivities. In general, major thrust faults could not be correlated with simulated and estimated water levels or with transmissivities at the scale of the model. Perhaps this is due to masking by other features or due to the size of the model cells used in the simulations; or perhaps the effects of these features on regional ground-water flow are minimal. Thrust faults might act as barriers to flow, particularly to vertical flow, where less permeable rocks have been thrust over more permeable rocks or where gouge along the thrust has been altered to clay. However, thrust faults could also increase the transmissive properties of rocks due to fracturing of brittle rocks, particularly near the center of folds or along the margins of the thrust plates.

Shear zones also could not be correlated with simulated water levels and transmissivities. Winograd and Thordarson (1975, p. 67) discussed evidence that the Las Vegas Valley shear zone (fig. 22A) acts as a barrier to flow. Evidence for a barrier is based on a water-level difference of $600 \mathrm{ft}$ measured from two wells that are $3 \mathrm{mi}$ apart. They assumed that most of this difference takes place in the vicinity of the shear zone instead of assuming a more gradual gradient between the two wells. The Pahranagat shear zone (fig. 22A) may also restrict ground-water flow. The Walker belt (fig. 22A) may restrict flow, but the zone is an area of abundant volcanic activity (Carr, 1984) and also corresponds to the approximate area where exposures of Precambrian and Cambrian clastic and crystalline rocks are common in the mountain ranges. Thus, on a regional basis it is not possible to determine if strike-slip faults along the Walker belt act as barriers or if flow is restricted by some other geologic feature.

The lack of correlation of simulated water levels and transmissivities with strike-slip faults could reflect how the model averages water levels and transmissivities within each cell. A steep drop across a small distance of a mile or so could not be simulated with model cells that are $5 \mathrm{mi}$ by $7.5 \mathrm{mi}$. Instead, a smoother gradient and a less severe change in transmissivity was simulated, thus possibly masking any local effects that could be related to a series of strike-slip faults.

Shear zones might act as barriers to flow but also could act as conduits along the direction of strike. This possibility could not be simulated in the model because anisotropy of selected cells could not be simulated without simulating anisotropy in every cell of a model layer. Increasing transmissivity in the direction of strike along the shear zones for all model cells could not be justified, because most normal faults in the study area are at right angles to the shear zones and could just as easily act as conduits along their strike.

Perhaps more important than the lineaments as ground-water barriers are the distribution of low-permeability rocks. Low-permeability rocks include intrusive rocks, metamorphic rocks that may be associated with the intrusives, and Precambrian and Cambrian igneous, metamorphic, and clastic rocks (Plume, 1995). The distribution of these rocks is shown in figure 23 along with simulated water levels, areas of ground-water evapotranspiration, and estimated boundaries of ground-water flow for the upper model layer. Lowpermeability rocks south of the transverse crustal boundary (south of latitude $36^{\circ}$ ) are generally Precambrian and Cambrian clastic and crystalline rocks; this suggests that carbonate rocks are not very thick or are absent over parts of the area. 

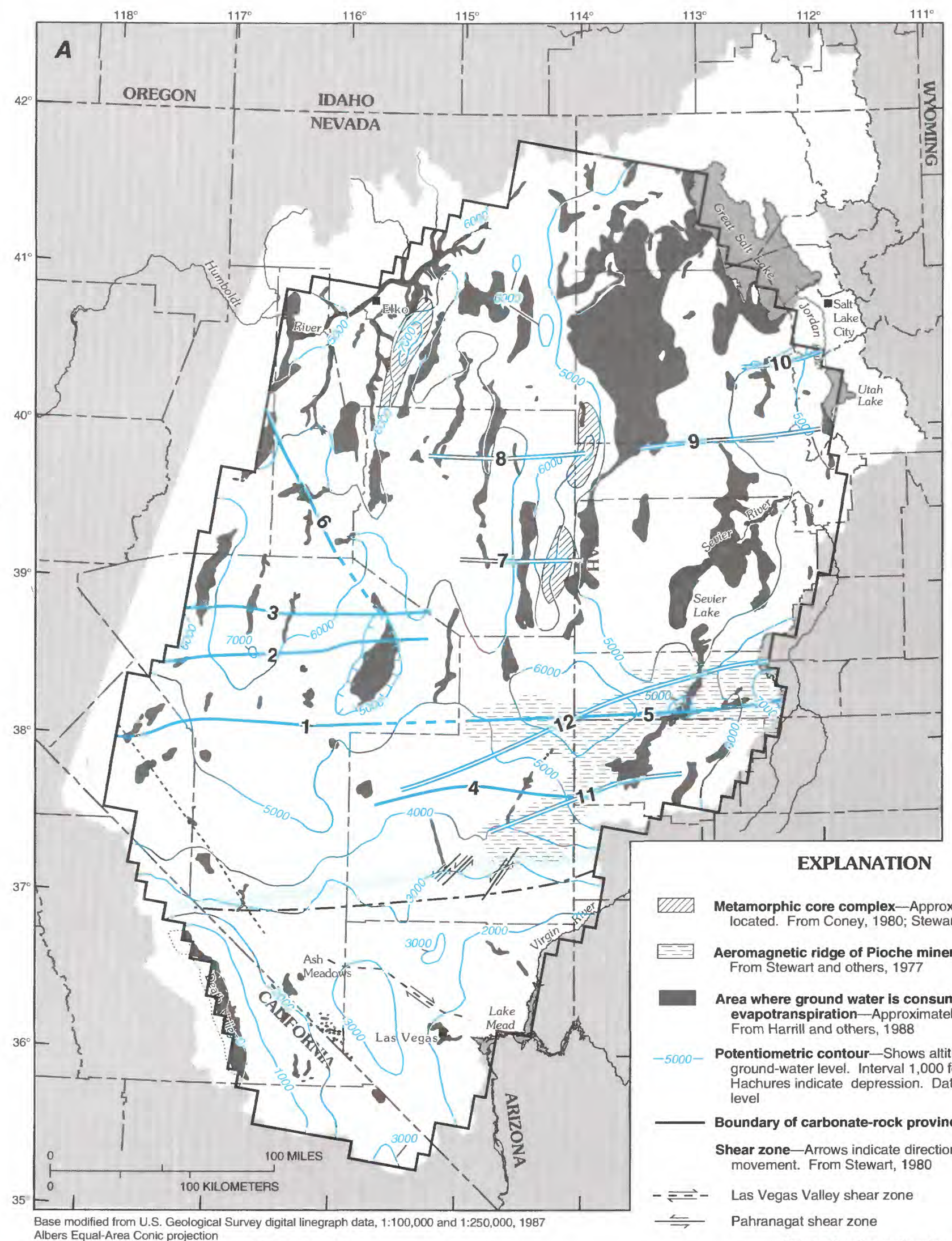

Metamorphic core complex-Approximately located. From Coney, 1980; Stewart, 1980

Aeromagnetic ridge of Pioche mineral beltFrom Stewart and others, 1977

Area where ground water is consumed by evapotranspiration-Approximately located. From Harrill and others, 1988

Potentiometric contour-Shows altitude of ground-water level. Interval 1,000 feet.

Hachures indicate depression. Datum is sea level

Boundary of carbonate-rock province model

Shear zone-Arrows indicate direction of relative movement. From Stewart, 1980

- $=-\quad$ Las Vegas Valley shear zone

Base modified from U.S. Geological Survey digital linegraph data, 1:100,000 and 1:250,000, 1987 Albers Equal-Area Conic projection

Standard parallels $29^{\circ} 30^{\prime}$ and $45^{\circ} 30^{\prime}$, central meridian $-114^{\circ}$

$\leftrightharpoons$ Pahranagat shear zone

Figure 22.- Relation between selected geologic features and simulated ground-water levels, areas of evapotranspiration, and location of springs simulated in model. $A$, Upper model layer. $B$, Lower model layer. 


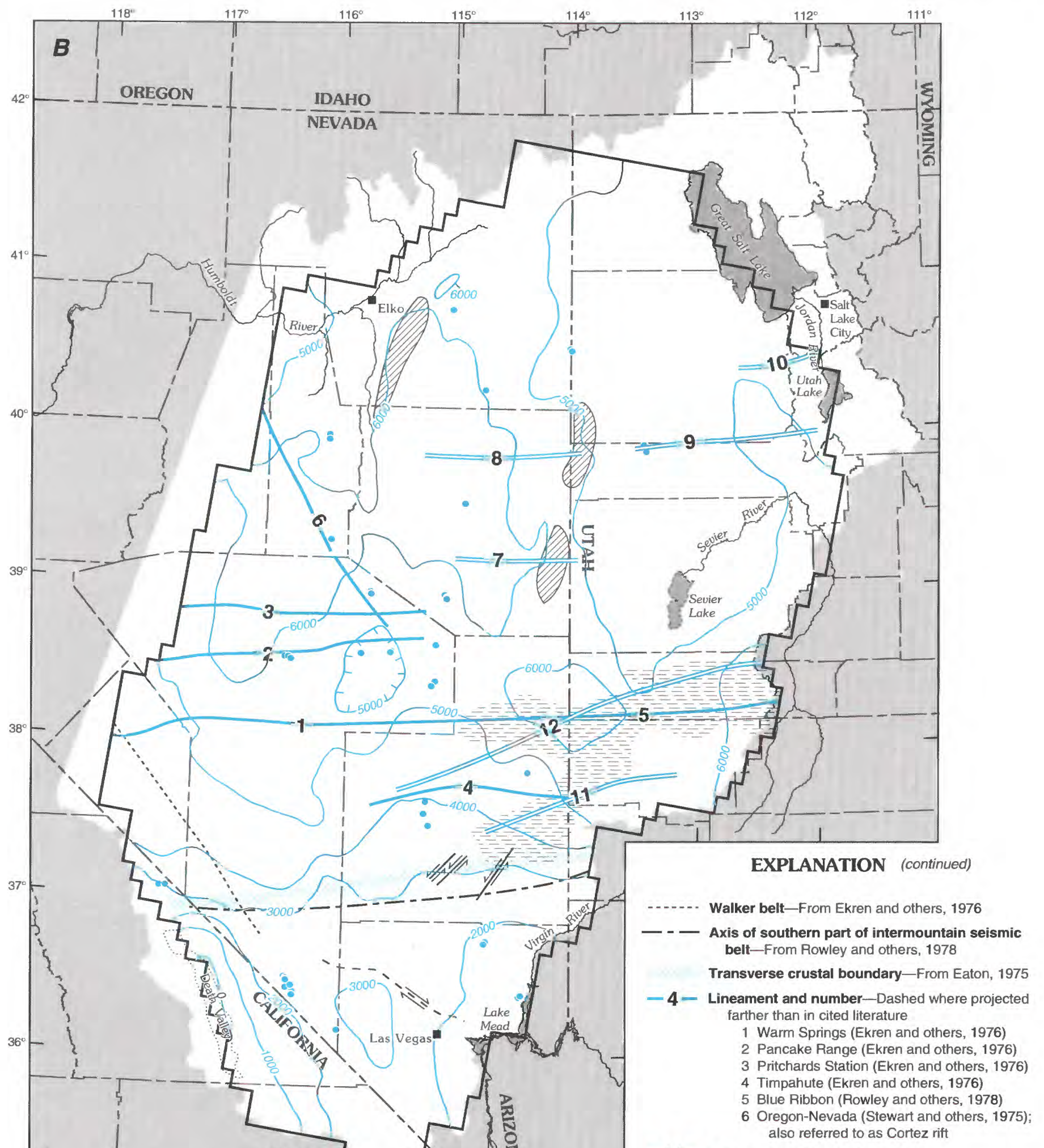

$=11=$ Axis of mineral belt and number

7 Hamilton-Ely (Roberts, 1964, 1966)

8 Cherry Creek (Roberts, 1964, 1966)

9 Deep Creek-Tintic (Shane and Stewart, 1976)

10 Oquirrh-Uinta (Shane and Stewart, 1976)

11 Delmar-Iron Springs (Shane and Stewart, 1976)

12 Pioche (Shane and Stewart, 1976) 


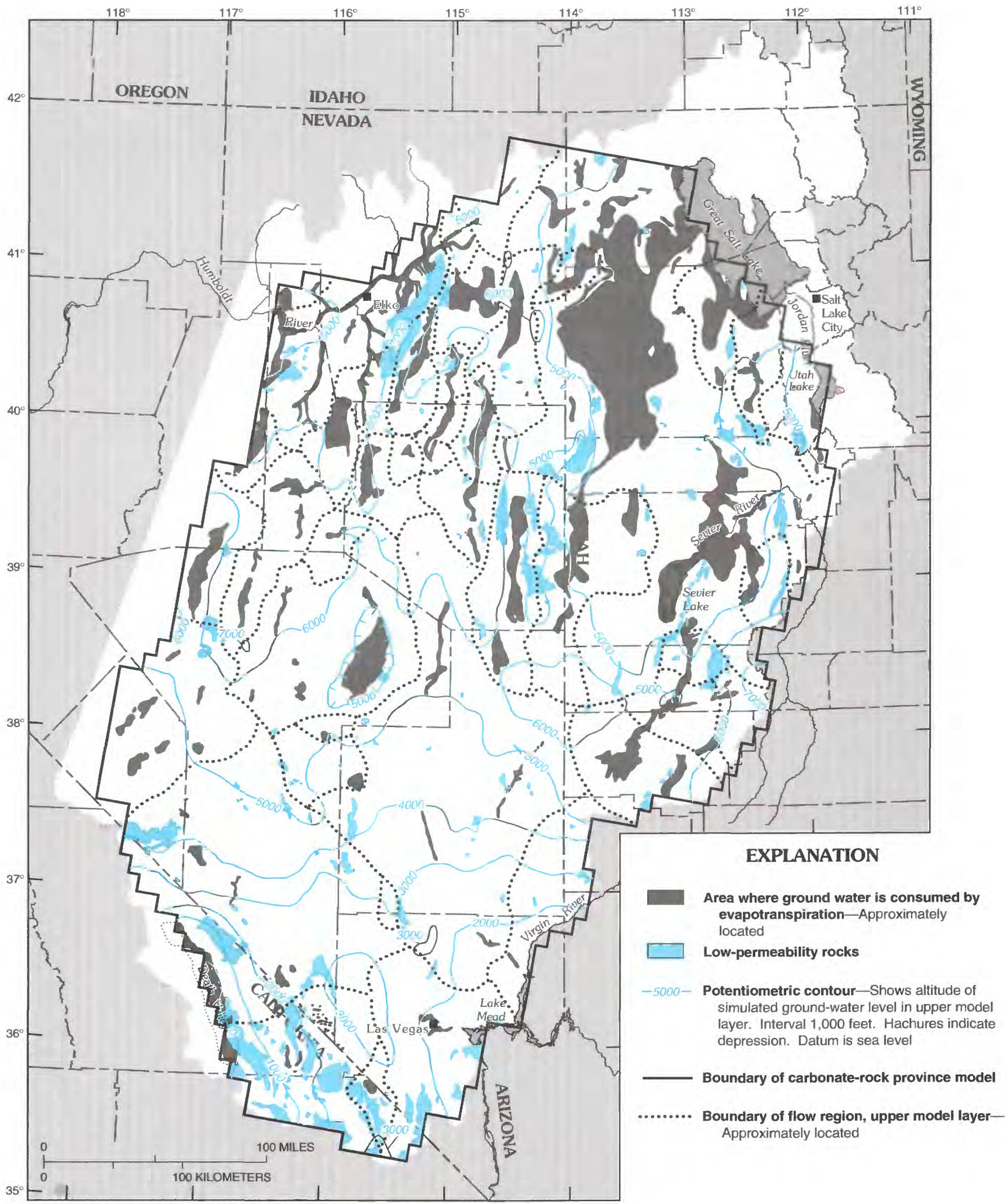

Base modified from U.S. Geological Survey digital linegraph data, 1:100,000 and 1:250,000, 1987 Albers Equal-Area Conic projection

Standard parallels $29^{\circ} 30^{\prime}$ and $45^{\circ} 30^{\prime}$, central meridian $-114^{\circ}$ 
Transmissivities in the upper model layer (fig. $20 \mathrm{~A}$ ) are generally low in model cells that correspond to outcrops of these rocks.

The distribution of low-permeability rocks in the subsurface may be more extensive than indicated by outcrop. Where present, these rocks could act as effective barriers to deep ground-water flow. Aeromagnetic data indicate that several subsurface magnetic bodies are present in the province; these are interpreted as low-permeability intrusive and igneous rocks (Plume, 1995). Large magnetic bodies are most prevalent in Utah, extreme eastern Nevada, and southern Nevada (fig. 24A). These bodies correspond to outcrop areas of intrusive and other crystalline rocks. A long, linear magnetic body in north-central Nevada is associated with the Oregon-Nevada lineament (fig. $22 B$ ). Only a few small magnetic bodies are present in east-central Nevada, an area devoid of extensive outcrops of low-permeability rocks. Transmissivities in the lower model layer are generally less than $0.006 \mathrm{ft}^{2} / \mathrm{s}$ in areas associated with the subsurface magnetic bodies (figs. $20 B$ and $24 A$ ). Consequently, only small quantities of flow are simulated in these areas. Several regional springs are upgradient from outcrop areas of low-permeability rocks or subsurface magnetic bodies (fig. $24 A, B)$, further suggesting that intrusive and other crystalline rocks are effective barriers to deep ground-water flow.

Ground-water flow also may be affected by the presence of metamorphic core complexes in the Ruby Mountains and the Deep Creek and Snake Ranges (fig. 24). These complexes include a metamorphic-plutonic basement terrane, an overlying transition zone of abrupt change in lithology and structure characterized by intense strain, and an unmetamorphosed cover characterized by low-angle detachment faults (Stewart, 1980, p. 80; Coney, 1980). Generally, transmissivities in the lower model layer are low in the vicinity of the metamorphic core complexes (fig. 20B), causing mounding effects at these locations. Simulated ground-water flow in areas of the core complexes is radially outward. Estimated recharge in mountains associated with the core complexes is higher than in adjacent mountains because the moun-

$\Leftarrow$

Figure 23.-Distribution of shallow-flow regions delineated in upper model layer in relation to (1) areas where ground water is consumed by evapotranspiration (Harrill and others, $1988, \mathrm{pl} .2),(2)$ simulated water levels in upper model layer, and (3) outcrops of low-permeability rocks (modified from Plume, 1995). tains are higher in altitude, thus contributing to the radial flow pattern.

The areas of high transmissivities (values exceeding $0.006 \mathrm{ft}^{2} / \mathrm{s}$ ) in the lower model layer correspond to areas near regional springs or to areas where estimated water budgets indicate interbasin flow. Elsewhere, the quantities of simulated deep flow are small, perhaps because the carbonate rocks are thin, are present as isolated blocks, or are buried beneath low-permeability rocks. High transmissivities may reflect areas where the carbonate rocks are thick and generally continuous. An area of high transmissivities extending from east-central Nevada into southern Nevada (fig. 25) generally corresponds to an area defined by Dettinger (1989, p. 13-16) as the central corridor (shown in figure 25). This corridor of carbonate rocks may be the principal conduit for regional flow from east-central Nevada into southern Nevada. High transmissivities in west-central Utah (fig. 25) also correspond to an area where carbonate rocks are continuous and relatively thick (Carlton, 1985, p. 11). This area is simulated as a major conduit for northward flow from western Utah into the southern end of the Great Salt Lake Desert. The high transmissivities adjacent to regional springs is consistent with the results of aquifer tests of carbonate rocks in eastern and southern Nevada. Results from aquifer tests indicate that the carbonate rocks are, on the average, 25 times more transmissive within 10 miles of regional springs than farther away (Dettinger, 1989 , p. 16).

\section{DISTRIBUTION OF FLOW INTO REGIONS}

Ground-water flow in the carbonate-rock province is generally from recharge areas in the mountains to discharge areas on the valley floors. Much of this is shallow flow from a local recharge area to an adjacent valley floor. However, in areas where permeable consolidated rocks (primarily fractured carbonate rocks) exist, ground water can flow at greater depths beneath mountains and valley floors. The deeper water can originate in distant recharge areas outside the topographic drainage basin in which it is discharged. Groundwater flow through deep permeable consolidated rocks is best exemplified by large springs or spring groups, from which the discharge greatly exceeds the estimated local recharge. Examples include the springs in Ash Meadows (Winograd and Thordarson, 1975 , p. 75-78), the Muddy River 


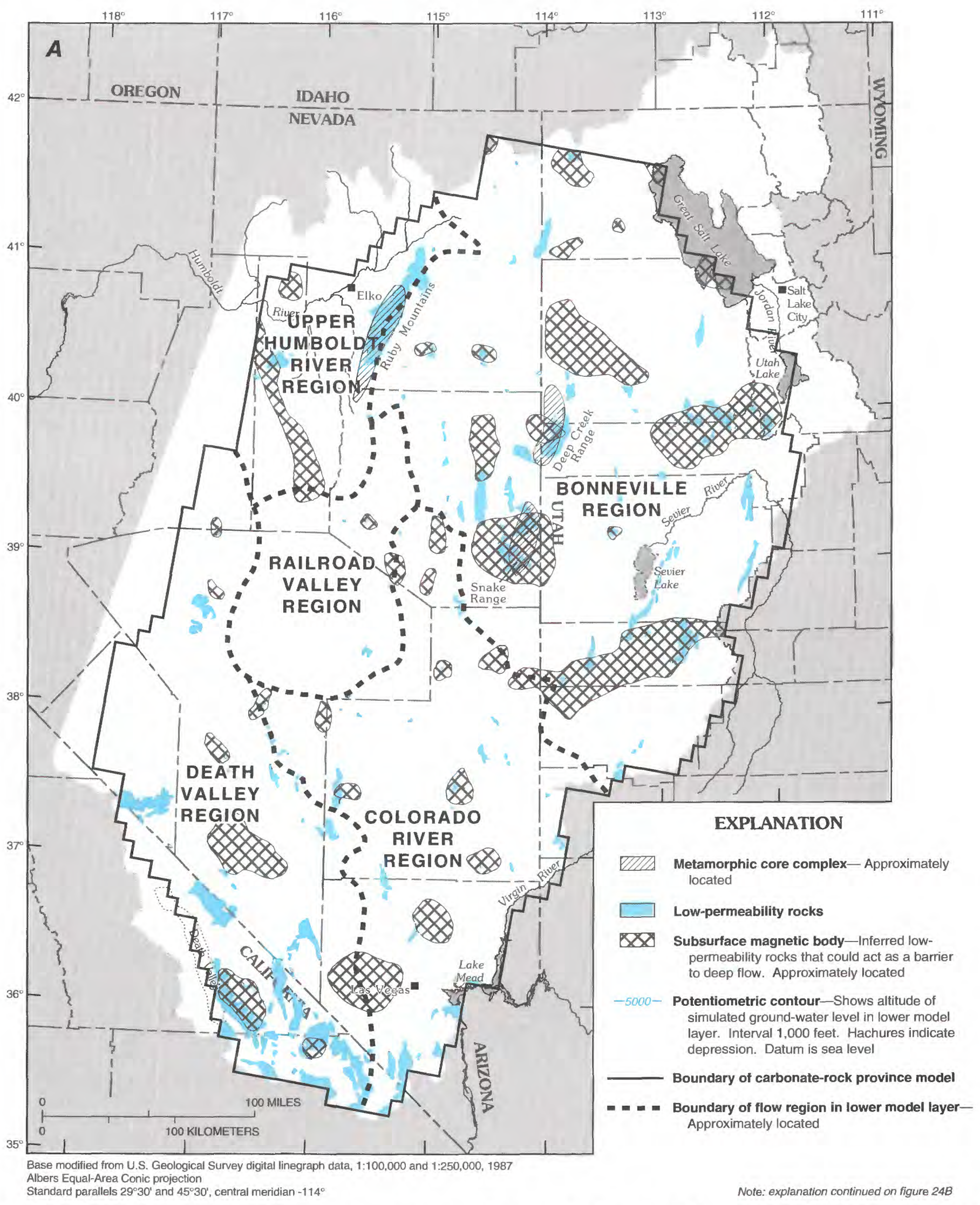

FIGURE 24.-Distribution of deep-flow regions and subregions delineated in lower model layer in relation to (A) metamorphic core complexes (Coney, 1980; Stewart, 1980), low-permeability rocks and magnetic source bodies (modified from Plume, 1995); and $(B)$ generalized directions of deep ground-water flow. 

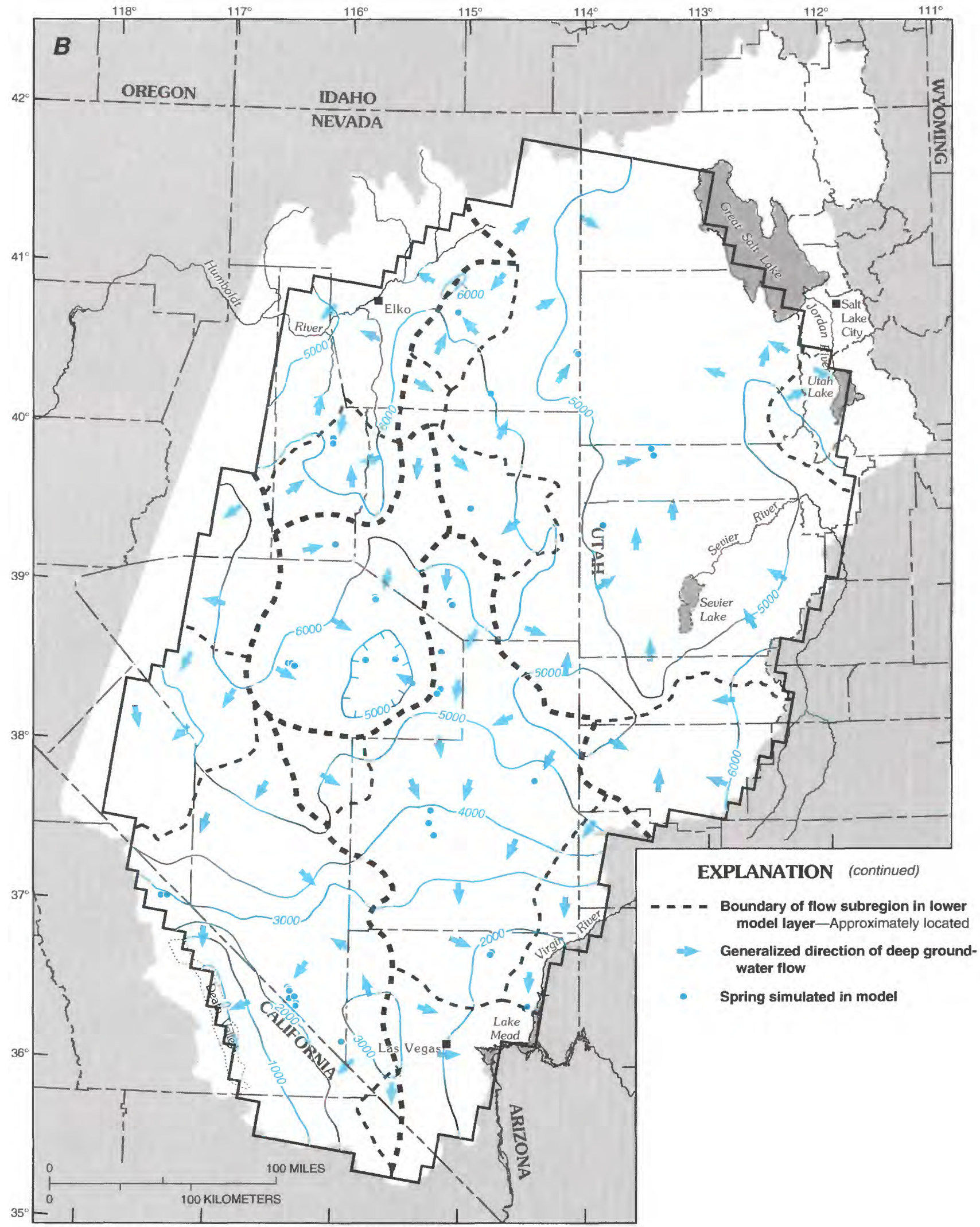

Spring simulated in model

Base modified from U.S. Geological Survey digital linegraph data, 1:100,000 and 1:250,000, 1987 Albers Equal-Area Conic projection

Standard parallels $29^{\circ} 30^{\prime}$ and $45^{\circ} 30^{\prime}$, central meridian $-114^{\circ}$ 


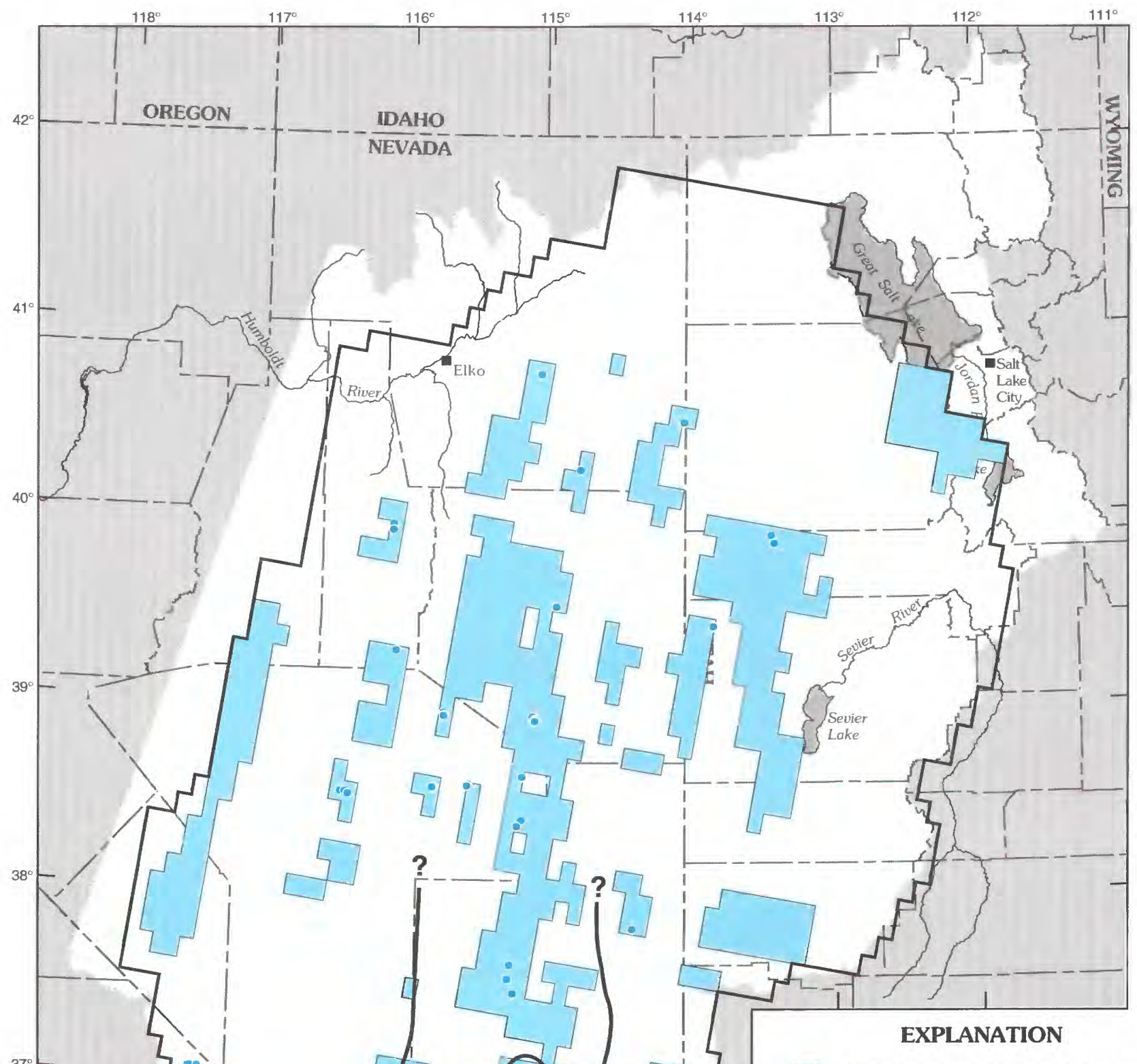

High transmissivity zone-Shows area where estimated transmissivities in lower layer exceed 0.006 feet squared per second

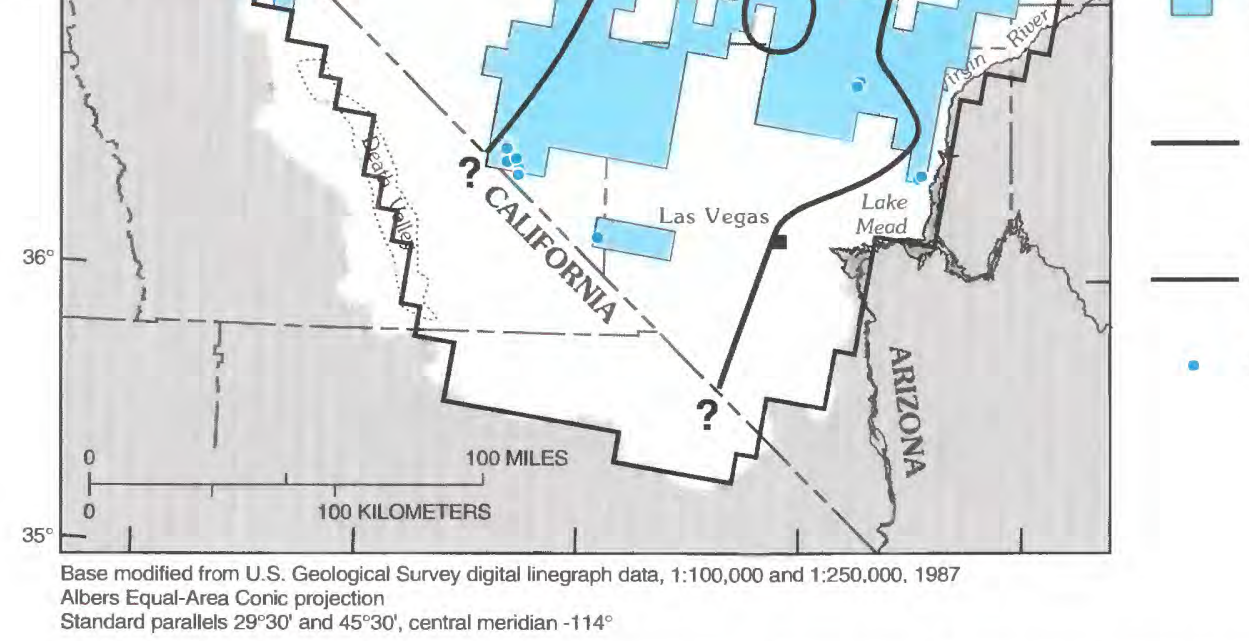

Boundary of central corridor of thick carbonate rocks - Approximately located. Queried where not delineated. (From Dettinger, 1989, p.14)

Boundary of carbonate-rock province model

Spring simulated in model

FIGURE 25.-Distribution of high transmissivities in lower model layer in relation to springs simulated in model and to boundary of central corridor of thick carbonate rocks in south-central Nevada. 
Springs (Eakin, 1966, p. 251), and the Fish Springs (Bolke and Sumsion, 1978, p. 13). A schematic depiction of shallow flow overlying deep regional flow, which is based on concepts presented by Tóth (1962, 1963) and Freeze and Witherspoon (1966, 1967), is shown for the carbonate-rock province in figure 26.

The delineation of flow regions in both model layers is based on a graphical plot of horizontal flow across common boundaries between model cells, which are referred to as cell faces (fig. 26). The flow-region boundaries in each model layer were hand drawn on 1:1,000,000-scale maps considering only horizontal flow within each layer. Vectors were machine drawn on the maps at the center of each cell face in the direction of horizontal flow; the length being proportional to the base 10 logarithm of the simulated flow across the cell face. Cells having inward, horizontal flow from adjacent cells in each layer were first identified, then the area contributing horizontal flow to these cells was determined from flow vectors in surrounding cells. In some areas, as in the Great Salt Lake Desert, groups of cells having inward flow are considered a single sink.

Flow regions in the upper model layer are referred to as shallow-flow regions. Forty-five regions are delineated in the model (fig. 23).

Active cells in the lower model layer are grouped into deep-flow regions (fig. 24A). The regions are delineated for terrain in which water levels generally decline toward one of five major discharge areas. Four of the flow regions are named for the geographic area of lowest land-surface altitude and lowest ground-water level within that region. Thus, the flow region in which water levels and land surface generally decrease toward Death Valley is called the Death Valley region. Other regions named this way are the Colorado River, Railroad Valley, and upper Humboldt River regions. The huge area that includes Great Salt Lake and the Great Salt Lake Desert is named the Bonneville region because most of it was inundated by pluvial Lake Bonneville during the Pleistocene epoch. Not all horizontal flow in the lower layer reaches one of the major regional discharge areas. Thus, deep-flow regions are further divided into subregions. Seventeen subregions are delineated in the lower layer (fig. $24 B$ ).

The number of subregions in the lower layer is the same as the number of flow systems delineated by Harrill and others (1988, pl. 2), although the boundaries between subregions do not everywhere correspond to those of the flow systems.
Flow-system boundaries drawn by Harrill and others (1988) are along topographic divides between hydrographic areas and are based on water-level gradients and flow budgets in each hydrographic area. In contrast, the subregion boundaries delineated herein are not constrained by topographic divides and hydrographic areas. Instead, they are based on the area within the lower layer that contributes horizontal flow to model cells having inward flow.

Boundaries of deep-flow regions (fig. 24A) do not everywhere correspond to boundaries of shallow-flow regions (fig. 23). For example, the Colorado River deep-flow region (fig. $24 \mathrm{~A}$ ) underlies several shallow-flow regions that also overlap the adjacent Bonneville and Death Valley deep-flow regions. Similarly, the Railroad Valley deep-flow region underlies several shallow-flow regions that also overlap the adjacent upper Humboldt River and Death Valley deep-flow regions. This results in the simulation of upper-layer flow that moves across underlying boundaries of deep-flow regions (fig. 26B). Although model results indicating differences in the horizontal directions of shallow flow and deep flow are simulated on the basis of limited data, such differences have been reported in central Nevada (Dinwiddie and Schroder, 1971). The general patterns of ground-water flow in both model layers shown in figure $26 B$ depend on (1) the configuration of the water table simulated in the upper layer and (2) the hydraulic properties assigned to model cells in both layers. The effect of these two factors in combination with a third factor-the ratio of depth to lateral extent for a basin-is discussed by Freeze and Witherspoon (1967, p. 625-632).

Vertical flow between model layers is illustrated in figure 27. Vertical flow between layers for each cell is depicted as being predominantly upward, predominantly downward, or negligible (less than $0.01 \mathrm{ft}^{3} / \mathrm{s}$ over a cell area of $37.5 \mathrm{mi}^{2}$ ). Downward flow is generally simulated in model cells corresponding to areas of recharge. Upward flow is generally simulated in areas of discharge. Little vertical (as well as horizontal) flow is simulated in the Great Salt Lake Desert because little ground water is estimated to discharge there. Consequently, estimated transmissivities and vertical leakances of cells in the area are among the lowest in the model.

A total of 428,000 acre-ft/yr (28 percent of total recharge to the model) is simulated as downward flow from the upper layer to the lower layer. Discharge at regional springs accounts for 211,000 acre-ft/yr of the flow out of the lower layer (which 

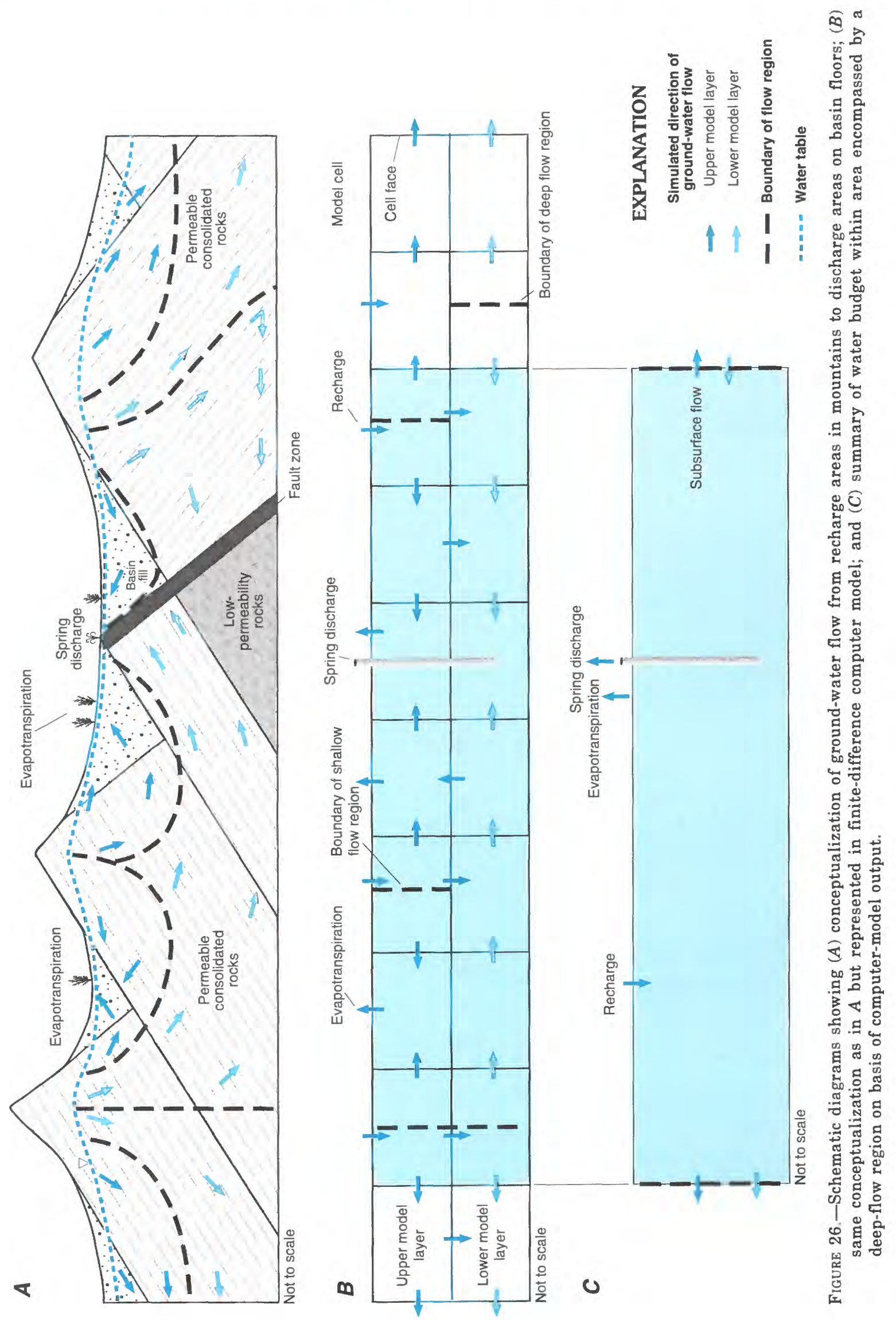

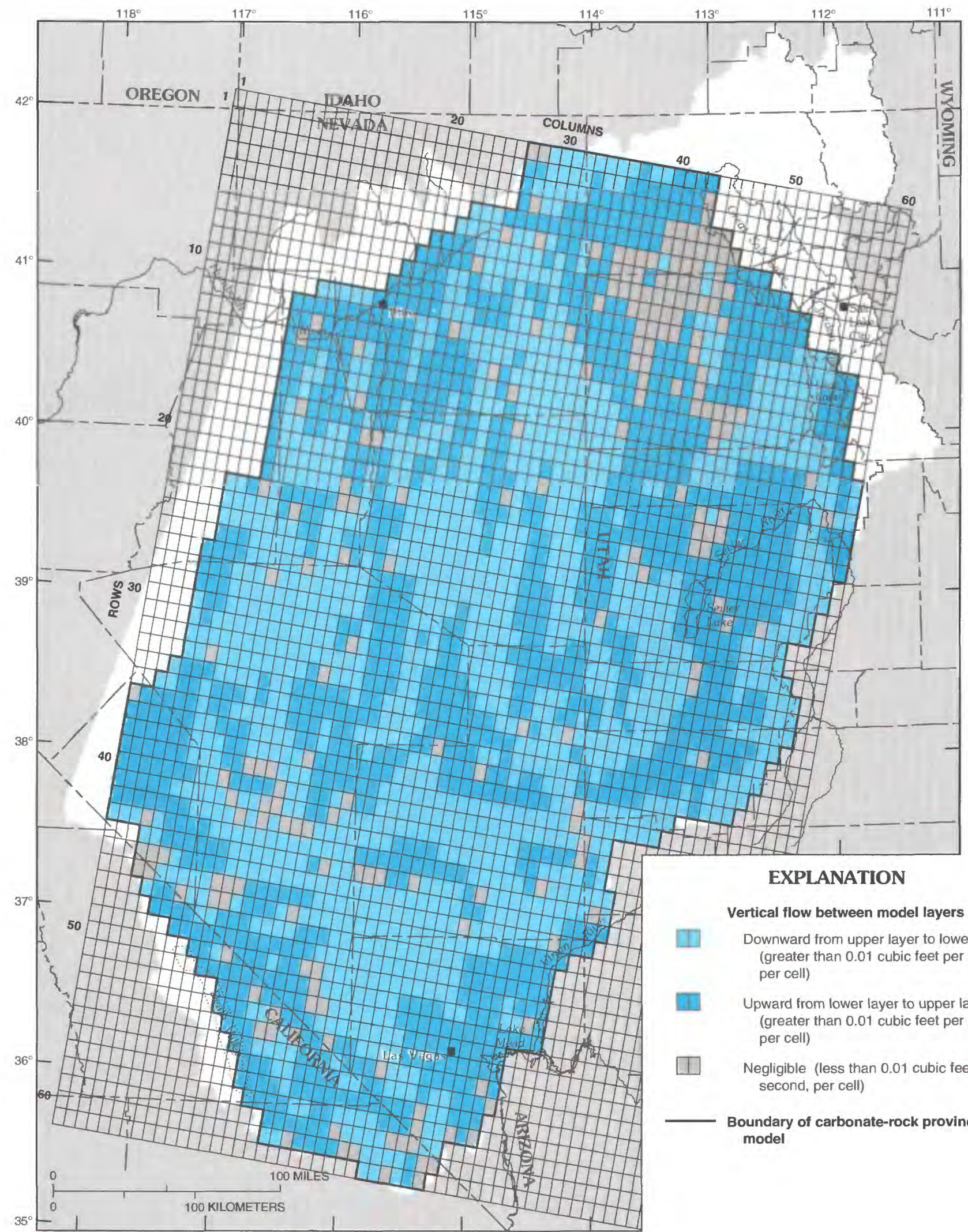

Downward from upper layer to lower layer (greater than 0.01 cubic feet per second, per cell)

Upward from lower layer to upper layer (greater than 0.01 cubic feet per second, per cell)

Negligible (less than 0.01 cubic feet per second, per cell)

\section{Boundary of carbonate-rock province} model

Base modified from U.S. Geological Survey digital linegraph data, 1:100,000 and 1:250,000, 1987 Albers Equal-Area Conic projection

Standard parallels $29^{\circ} 30^{\prime}$ and $45^{\circ} 30^{\prime}$, central meridian $-114^{\circ}$

FIGURE 27.-Distribution of vertical flow between model layers. 
is equivalent to 49 percent of the downward flow into the lower layer). The remaining 217,000 acre$\mathrm{ft} / \mathrm{yr}$ ( 51 percent) is upward leakage to the upper layer.

Results of model simulations are summarized in a separate section for each of the five deepflow regions. Flow in each region is compared with flow described by other investigators. A simulated ground-water budget is presented for each deepflow region and subregion. The budget, calculated using a computer program written by Harbaugh (1990), includes the flow through corresponding cells in the upper model layer-that is, the budget includes all recharge and discharge in both model layers within each deep-flow region and subregion. Although flow-region boundaries do not, in theory, have flow across them, the budget for each deep-flow region and subregion includes subsurface flow to or from adjacent regions or subregions. This cross-boundary flow is included for two reasons. First, the boundaries of deep-flow regions and subregions commonly are drawn within model cells (fig. 26B), but the cells that straddle a boundary are assigned to only one of the two regions or subregions for water-budget calculations (fig. 26C). Second, upper-layer flow in a shallow-flow region can cross the underlying boundary of a deep-flow region or subregion in places where the shallow-flow and deep-flow boundaries do not coincide (fig. 26B, C). Most of the cross-boundary flow takes place in the upper layer.

The simulated ground-water budget for each deep-flow region and subregion is summarized in terms of inflow and outflow components. Inflow includes recharge assigned to the upper model layer beneath mountain ranges, leakage to the upper layer from head-dependent flow boundaries, and subsurface flow from adjacent regions and subregions in both layers. Outflow includes evapotranspiration and leakage to head-dependent flow boundaries from the upper layer, regional spring discharge from the lower layer, and subsurface flow to adjacent regions and subregions in both layers. The evapotranspiration and leakage components of outflow include spring flow that is not assigned to regional springs in the lower model layer. Head-dependent flow boundaries are used in the model to simulate leakage of ground water to or from the principal rivers, lakes, and sinks (including Death Valley) that border or are within the model area. These boundaries allow either inflow to or outflow from the upper layer. Thus, leakage components are included as both inflow and outflow for the budget of each deep-flow region and subregion.
Recharge areas contributing flow to regional springs are determined on the basis of a computer program that tracks ground-water flowpaths backward (upgradient) from the model cells that represent the springs (Pollock, 1989). The program is not used to determine the increment of flow from each contributing area, because porosities and cell thicknesses in the model area are largely unknown. The areal distribution of incoming flow to each regional spring is indicated in a general way by comparing the flow quantities computed for each face of the cell that represents the spring.

Although the directions of ground-water flow and the quantities of inflow and outflow are described in quantitative detail for each deep-flow region, the uncertainties in estimating recharge and evapotranspiration, and the lack of information on hydraulic properties and extent of rock units in the subsurface, result in several alternatives regarding directions and quantities of ground-water flow within the carbonate-rock province. Thus, the conceptualization presented herein is but one of several possible scenarios. Some alternative scenarios-particularly with regard to the flow of ground water to major discharge areas-are also discussed.

\section{FLOW REGIONS}

\section{DEATH VALLEY REGION}

The Death Valley region, in the southwestern part of the study area (fig. $24 A$ ), encompasses about $19,000 \mathrm{mi}^{2}$. It includes four deep-flow subregions in the lower model layer-Big Smoky, Clayton, Pahrump-Amargosa, and Mesquite (fig. 28) -and all or part of eight shallow-flow regions in the upper model layer (fig. 23). Little groundwater flow is simulated between deep-flow subregions even though water levels generally decline toward Death Valley.

The Death Valley region includes some of the most intensively studied terrane in the Great Basin. With the inception of underground nuclear explosions at the Nevada Test Site in 1957, detailed investigations were begun to determine the occurrence and movement of ground water within and adjacent to the Test Site, thereby permitting an assessment of ground-water contamination (Winograd and Thordarson, 1975, p. C1). Results of these investigations have been summarized in several reports (Winograd and Eakin, 1965; Winograd and Thordarson, 1968, 1975; Rush, 1970; 
Winograd and Friedman, 1972; Blankennagel and Weir, 1973; Naff and others, 1974; Winograd and Pearson, 1976; Waddell, 1982; Czarnecki and Waddell, 1984; Waddell and others, 1984).

\section{INFLOW}

Total inflow to the Death Valley region is 177,000 acre-ft/yr, of which recharge assigned to

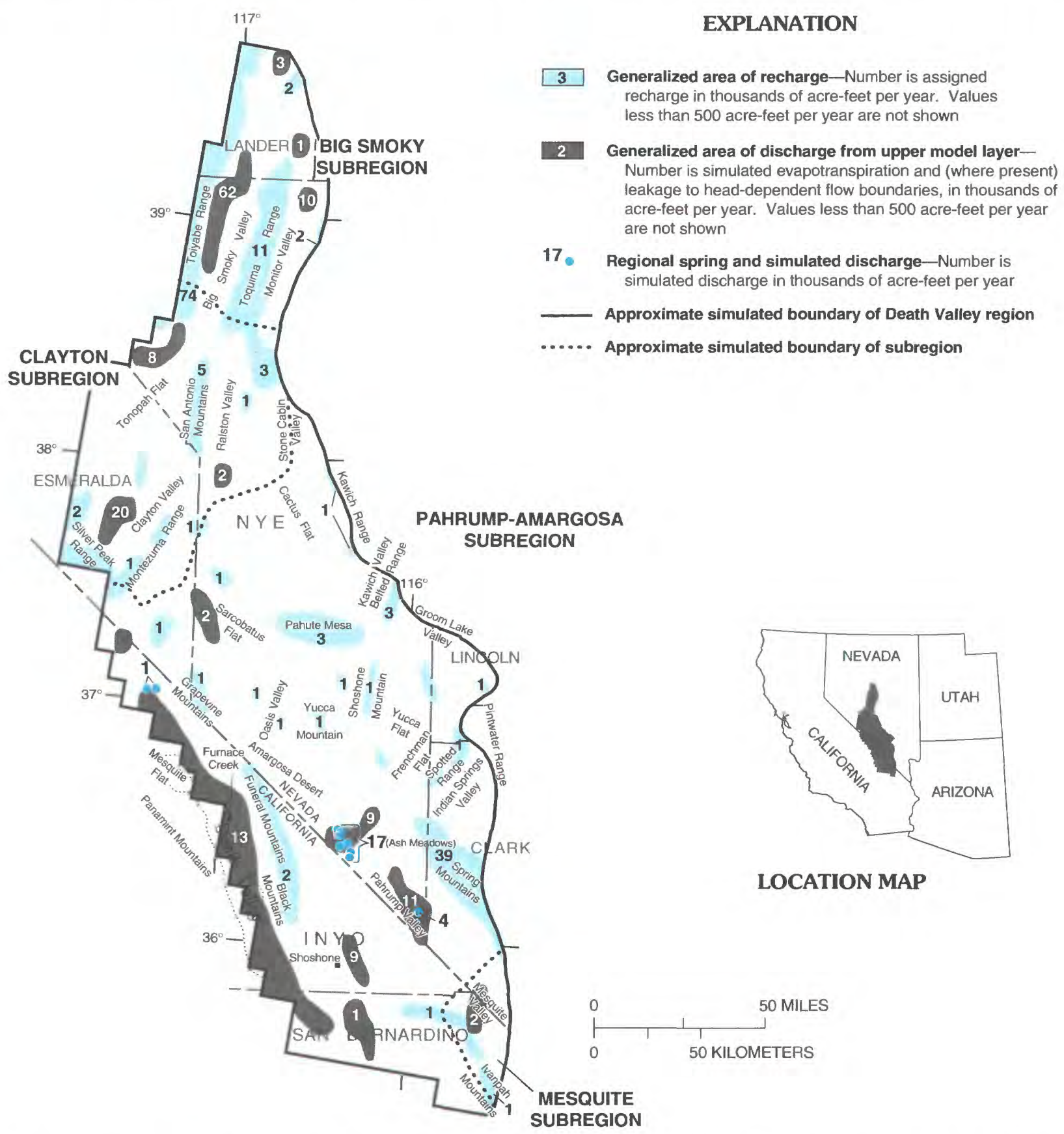

cells in the upper model layer totals about 161,000 acre-ft/yr (table 4). Principal recharge areas include the Toquima Range and eastern slope of the Toiyabe Range in the north, and the Spring Mountains in the south (fig. 28). Small quantities of recharge are also simulated in several other mountain ranges. The remaining 16,000 acre- $\mathrm{ft} / \mathrm{yr}$ of simulated inflow enters the region as subsurface flow in both layers from adjacent regions (table 4): About 6,000 acre-ft/yr is simulated to the Big

\section{EXPLANATION}

eneralized area of recharge-Number is assigned recharge in thousands of acre-feet per year. Values neralized area of discharge from upper model layerNumber is simulated evapotranspiration and (where present)

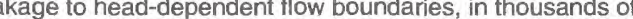
cre-feet per year. Values less than 500 acre-feet per year gional spring and simulated discharge-Number is muled discharge in thousands of acre-feet per year 
TABLE 4.-Simulated ground-water flow budgets, Death Valley region

[All amounts are in acre-feet per year (acre-ft/yr), rounded to nearest 1,000 acre-ft/yr. Amounts of mountain recharge are assigned, as described in text section title "Estimates of Recharge"; all other listed amounts are determined from model simulation]

\begin{tabular}{|c|c|c|c|c|c|}
\hline $\begin{array}{l}\text { Budget component and } \\
\text { (in parentheses) } \\
\text { primary model layer involved }\end{array}$ & $\begin{array}{l}\text { Big Smoky } \\
\text { subregion }\end{array}$ & $\begin{array}{l}\text { Clayton } \\
\text { subregion }\end{array}$ & $\begin{array}{l}\text { Mesquite } \\
\text { subregion }\end{array}$ & $\begin{array}{l}\text { Pahrump- } \\
\text { Amargosa } \\
\text { subregion }\end{array}$ & $\begin{array}{l}\text { Entire Death } \\
\text { Valley region }\end{array}$ \\
\hline \multicolumn{6}{|l|}{ INFLOW } \\
\hline Mountain recharge (upper) & 75,000 & 25,000 & 1,000 & 60,000 & 161,000 \\
\hline $\begin{array}{l}\text { Subsurface inflow from adjacent } \\
\text { regions (both) }\end{array}$ & $a_{6,000}$ & $a_{1,000}$ & minor & $b_{9,000}$ & 16,000 \\
\hline $\begin{array}{l}\text { Subsurface inflow from adjacent } \\
\text { subregions (both) }\end{array}$ & 0 & $c_{5,000}$ & 0 & minor & (d) \\
\hline Total inflow & 81,000 & 31,000 & 1,000 & 69,000 & 177,000 \\
\hline \multicolumn{6}{|l|}{ OUTFLOW } \\
\hline Evapotranspiration $^{e}$ (upper) & 77,000 & 31,000 & 2,000 & 37,000 & 147,000 \\
\hline Regional springs (lower) & 0 & 0 & 0 & 22,000 & 22,000 \\
\hline $\begin{array}{l}\text { Subsurface outflow to adjacent } \\
\text { regions (both) }\end{array}$ & $f_{1,000}$ & 0 & 0 & $g_{2,000}$ & 3,000 \\
\hline $\begin{array}{l}\text { Subsurface outflow to adjacent } \\
\text { subregions (botb) }\end{array}$ & $h_{4,000}$ & 0 & 0 & $h_{1,000}$ & (d) \\
\hline Leakage (upper) & 0 & 0 & 0 & $i_{8,000}$ & $i_{8,000}$ \\
\hline Total outflow $j$ & 82,000 & 31,000 & 2,000 & 70,000 & 180,000 \\
\hline
\end{tabular}

${ }^{a}$ From Railroad Valley region.

${ }^{b}$ Includes 8,000 acre-ft/yr from Colorado River region and 1,000 acre-ft/yr from Railroad Valley region.

c Includes 4,000 acre-ft/yr from Big Smoky subregion and 1,000 acre-ft/yr from Pahrump-Amargosa subregion.

${ }^{d}$ Net flow among subregions within Death Valley region is zero.

e Includes evapotranspiration of flow from small springs that are assumed to be discharging from upper layer; does not include evapotranspiration of flow from regional springs that are simulated to be discharging from lower layer.

$f$ To upper Humboldt River region.

$\boldsymbol{g}$ To Colorado River region.

h To Clayton subregion.

i To Death Valley playa.

$j$ Total outflow does not always equal total inflow due to rounding of individual values.

Smoky subregion from the Railroad Valley region, about 8,000 acre-ft/yr to the Pahrump-Amargosa subregion from the Colorado River region, and 1,000 acre-ft/yr each to the Clayton and PahrumpAmargosa subregions from the Railroad Valley region.

\section{OUTFLOW}

Simulated outflow from the Death Valley region is 180,000 acre-ft/yr, of which 147,000 acre$\mathrm{ft} / \mathrm{yr}$ is evapotranspiration from the upper model layer (table 4). Principal areas of simulated evapotranspiration are in Big Smoky Valley, Monitor
Valley, and Clayton Valley in the north, and Ash Meadows in Amargosa Desert, Pahrump Valley, and Death Valley in the south (fig. 28). In addition, 22,000 acre-ft/yr is simulated as discharge from regional springs in the lower layer, 8,000 acre-ft/yr as discharge to the Death Valley playa through head-dependent flow boundaries in the upper layer, and 3,000 acre-ft/yr as subsurface flow to adjacent regions in both layers. Simulated discharge from regional springs includes 17,000 acre-ft/yr at Ash Meadows, 3,900 acre-ft/yr at Manse Springs in Pahrump Valley, and 720 acre$\mathrm{ft} / \mathrm{yr}$ at Grapevine and Stainigers Springs at the north end of Death Valley (table 1). Spring discharge at Furnace Creek in Death Valley (Nevares, 
Texas, and Travertine Springs) is included in the discharge to Death Valley playa.

\section{DESCRIPTION OF SUBREGIONS}

\section{BIG SMOKY SUBREGION}

The Big Smoky subregion, at the extreme northern end of the Death Valley region (fig. 28), encompasses about $2,400 \mathrm{mi}^{2}$. The boundary of the subregion differs from that of Harrill and others (1988) in that it extends to the east side of Monitor Valley instead of following the crest of the Toquima Range. Recharge assigned to cells in the upper model layer totals 75,000 acre-ft/yr (table 4); most of the recharge is from the Toiyabe Range. In addition to recharge, another 6,000 acre$\mathrm{ft} / \mathrm{yr}$ of subsurface flow enters the subregion from the Railroad Valley region, primarily through the upper model layer on the east side of Monitor Valley. Evapotranspiration from the upper layer accounts for most of the simulated outflow and totals 77,000 acre-ft/yr. Principal areas of evapotranspiration are northern Big Smoky Valley and Monitor Valley. A small quantity (about 1,000 acre$\mathrm{ft} / \mathrm{yr}$ ) leaves as subsurface flow to the upper Humboldt River region in the upper layer. About 4,000 acre-ft/yr leaves as subsurface flow to the Clayton subregion.

Low transmissivities are simulated in both model layers in cells corresponding to the Toquima Range and to mountains east of Monitor Valley (fig. 20). The low transmissivities are needed in the model to simulate evapotranspiration in Monitor Valley. Because of the low transmissivities in the Toquima Range, flow is simulated mostly in the upper layer from the mountain crest east to Monitor Valley and west to Big Smoky Valley. Most of the shallow and deep flow from the Toiyabe Range is simulated as moving to the large discharge area in northern Big Smoky Valley (fig. 29), where evapotranspiration from the upper layer is 62,000 acre-ft/yr. In comparison, 64,000 acre$\mathrm{ft} / \mathrm{yr}$ of evapotranspiration was estimated by Rush and Schroer (1970, p. 37-39), who also estimated another 5,000 acre-ft/yr as spring discharge but noted that part of the spring discharge was included in their estimate of evapotranspiration.

Flow at the north end of the Toquima Range is from Monitor Valley to Big Smoky Valley; the combined flow in both model layers is 700 acre$\mathrm{ft} / \mathrm{yr}$. The potential for flow exists between Monitor Valley and Big Smoky Valley because water levels in the former are higher than those in the latter. Thermal water discharges from springs at the north end of Big Smoky Valley, which indicates deep circulation of flow along faults or permeable rock. Volcanic rocks are common in the Toquima Range, but carbonate rocks crop out at a few locations. The sequence of carbonate rocks has been thickened as a result of westward movement and overthrusting along the Roberts Mountain thrust fault (McKee, 1976, p. 44-46). Where present, the carbonate rocks may provide an avenue for interbasin flow. However, enough precipitation falls in the drainage basin of Big Smoky Valley to account for the estimated discharge there (E.H. Handman, U.S. Geological Survey, written commun., 1992). Thus, if water does flow from Monitor Valley to Big Smoky Valley through the Toquima Range, the quantity must be small.

\section{CLAYTON SUBREGION}

The Clayton subregion, between the Big Smoky subregion and the Pahrump-Amargosa subregion (fig. 28), encompasses about $3,800 \mathrm{mi}^{2}$. The boundary of the Clayton subregion approximates the flow-system boundary delineated by Harrill and others (1988). Basins contributing subsurface ground-water inflow to Clayton Valley include southern Big Smoky Valley (Tonopah Flat) to the north, and Ralston and Stone Cabin Valleys to the northeast. Recharge assigned to cells in the upper model layer totals 25,000 acre-ft/yr (table 4 ). Most of the recharge is in the southern end of the Toiyabe and Toquima Ranges. An additional $6,000 \mathrm{acre}-\mathrm{ft} / \mathrm{yr}$ enters the subregion as subsurface flow, primarily in the upper layer (table 4): 4,000 acre-ft/yr from the Big Smoky subregion, and 1,000 each from the Pahrump-Amargosa subregion and Railroad Valley region. Subsurface flow out of the Clayton subregion is minimal. Flow in both model layers follows the same general path to Clayton Valley (fig. 29).

Major discharge areas include southern Big Smoky Valley (Tonopah Flat area) and Clayton Valley. Simulated evapotranspiration in the upper layer is 31,000 acre-ft/yr (table 4). Evapotranspiration in the Tonopah Flat area is about 8,000 acre-ft/yr, which is 2,000 acre-ft/yr more than that estimated by Rush and Schroer (1970, p. 38). However, simulated evapotranspiration in the model is concentrated in the northern part of Tonopah Flat, in an area of observed evapotranspiration, but not at the southern end, where additional evapotranspiration occurs. Evapotranspiration in Clayton Valley is about 20,000 acre-ft/yr-4,000 
acre-ft/yr less than the 24,000 acre-ft/yr estimated by Rush (1968a, p. 29).

Simulated flow from Tonopah Flat into Clayton Valley is about 11,000 acre-ft/yr, which is slightly less than the 13,000 acre-ft/yr ascribed as subsurface flow through carbonate rocks (Rush, 1968a, p. 26). Another 7,600 acre- $\mathrm{ft} / \mathrm{yr}$ is simulated as subsurface flow from the northeast, which is slightly more than the 5,000 acre-ft/yr reported by Rush (1968a, p. 27). Simulated subsurface flow into Clayton Valley is thus about equal to that previously estimated. The possibility of subsurface flow from adjacent basins into Clayton Valley was first mentioned by Meinzer (1917, p. 144).

During model calibration, transmissivities were increased in a narrow band from Big Smoky Valley to Clayton Valley in both model layers until they were generally in the range of 0.006 to 0.18

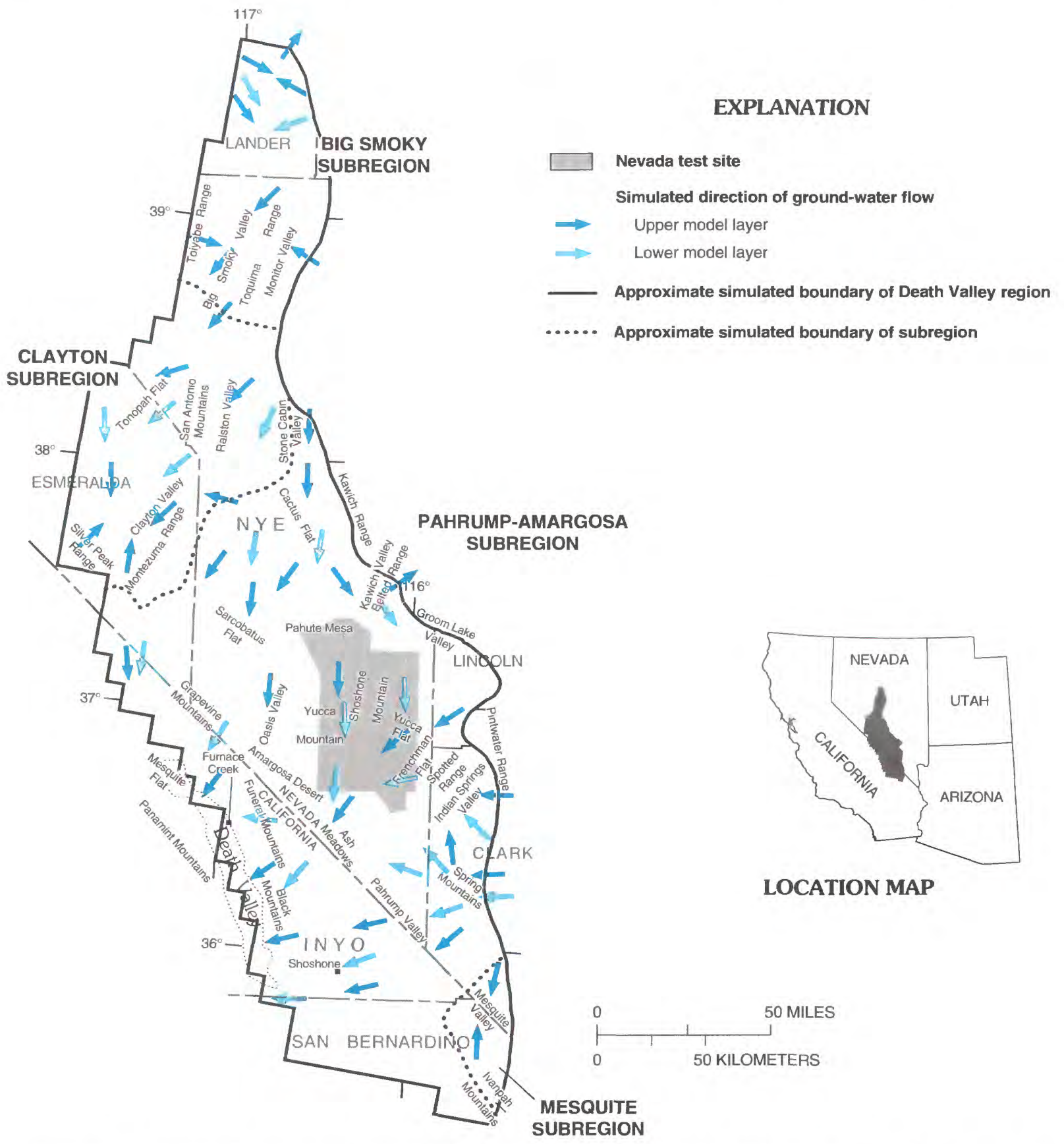

FIGURE 29.-Simulated direction of ground-water flow for both upper and lower model layers in Death Valley region. 
$\mathrm{ft}^{2} / \mathrm{s}$ (fig. 25). By increasing transmissivities, simulated evapotranspiration was decreased in northern Big Smoky Valley and Tonopah Flat, and increased in Clayton Valley, resulting in a better agreement with the estimated water levels. The simulated transmissivities bracket an estimated transmissivity of $0.09 \mathrm{ft}^{2} / \mathrm{s}(60,000[\mathrm{gal} / \mathrm{d}] / \mathrm{ft})$ reported by Rush (1968a, p. 27) for the area between Tonopah Flat and Clayton Valley.

\section{MESQUITE SUBREGION}

The Mesquite subregion, at the extreme southern end of the Death Valley region (fig. 28), encompasses only $490 \mathrm{mi}^{2}$. The subregion generally coincides with the Mesquite Valley hydrographic area and with a shallow-flow region delineated in the upper layer (fig. 23). The subregion boundaries generally correspond to boundaries of a flow system delineated by Harrill and others (1988). Inflow in the subregion is about 1,000 acre- $\mathrm{ft} / \mathrm{yr}$ and is recharge assigned to cells in the upper model layer. A minor quantity (less than 500 acre$\mathrm{ft} / \mathrm{yr}$ ) is simulated as subsurface flow from the Colorado River region in the upper layer. Discharge, simulated as evapotranspiration in Mesquite Valley from the upper layer, is about 2,000 acre-ft/yr (table 4), approximating the 2,200 acre$\mathrm{ft} / \mathrm{yr}$ estimated by Glancy (1968b, p. 26). The subregion does not contribute flow to either the Pahrump-Amargosa subregion or the Colorado River region. Most of the flow simulated in the subregion is within the upper layer. Transmissivities in the lower layer are among the lowest in the entire modeled area (fig. 20B); they correspond to an area of low-permeability rocks delineated by Plume (1995) and shown in figure 23.

\section{PAHRUMP-AMARGOSA SUBREGION}

The Pahrump-Amargosa subregion encompasses about $12,700 \mathrm{mi}^{2}$; it is the largest subregion delineated in the Death Valley region (fig. 28). The subregion extends from Stone Cabin Valley and the Kawich Range to the Ivanpah Mountains in California. The northern and southern boundaries of the subregion generally correspond to the flow-system boundary delineated by Harrill and others (1988). The eastern boundary of the subregion does not extend as far eastward as that of Harrill and others (1988). Hydrographic areas included by them but excluded herein are Tikaboo Valley, southern Railroad Valley, both parts of
Three Lakes Valley, and northern ends of Groom Lake and Kawich Valleys.

Recharge assigned to cells in the upper model layer totals 60,000 acre-ft/yr, of which nearly twothirds is in the Spring Mountains. An additional $8,000 \mathrm{acre}-\mathrm{ft} / \mathrm{yr}$ enters the subregion as subsurface flow from the Colorado River region in both layers. Most of this ground-water inflow is in the Spring Mountains, but about 700 acre-ft/yr enters the subregion near the Pintwater Range. About half of the simulated inflow along the Spring Mountains is in the lower model layer. Subsurface inflow in these mountains is the result of assigning cells along the crest, where flow is both eastward and westward, to the Colorado River region. About 1,000 acre-ft/yr enters the subregion as underflow from the Railroad Valley region (table 4).

Simulated outflow from the subregion totals 70,000 acre-ft/yr (table 4), including 37,000 acre$\mathrm{ft} / \mathrm{yr}$ as evapotranspiration from the upper model layer, 22,000 acre-ft/yr as regional-spring discharge from the lower layer, 8,000 acre-ft/yr as leakage to head-dependent flow boundaries in the upper layer associated with the Death Valley playa, and 2,000 and 1,000 acre-ft/yr as subsurface flow in both layers to the Colorado River region and Clayton subregion, respectively. Areas of evapotranspiration of shallow ground water in the subregion include those of Sarcobatus Flat, Oasis Valley, Amargosa Desert near Ash Meadows, Pahrump Valley, the lower Amargosa River near Shoshone, and Death Valley (Harrill and others, 1988). The only area of evapotranspiration not simulated is in Oasis Valley, where Malmberg and Eakin (1962, p. 25) estimated 2,000 acre-ft/yr of discharge along the channel of the Amargosa River. Simulated ground-water flow in the area of $\mathrm{Oa}$ sis Valley is southward into Amargosa Desert and then to Death Valley.

Total simulated discharge in Death Valley is about 14,000 acre-ft/yr, which includes the flow of Grapevine and Stainiger Springs at the north end (fig. 28), leakage to the head-dependent flow boundary cells associated with the playa, evapotranspiration at both the north and south ends of the playa, and evapotranspiration near Furnace Creek. Not including ground-water flow from the Panamint Mountains to the west, estimated discharge from the Death Valley playa is about $8,300 \mathrm{acre}-\mathrm{ft} / \mathrm{yr}$ (Hunt and others, 1966, p. B38, table 25). This value includes the flow of Nevares, Texas, and Travertine Springs near Furnace Creek, for which Hunt and co-workers estimated a total 
of 4,100 acre-ft/yr. Later, Miller (1977, p. 27) reported a combined discharge of 2,700 acre-ft/yr.

Evapotranspiration also occurs in a marsh area north of the playa, in Mesquite Flat, and at Grapevine and Stainiger Springs. Discharge in these areas is not part of the 8,300 acre-ft/yr. Estimated evapotranspiration from the marsh area is 3,000 5,000 acre- $\mathrm{ft} / \mathrm{yr}$; at Mesquite Flat, it is a "few thousand acre-ft/yr"; and the combined discharge of Grapevine and Stainiger Springs is about 1,000 acre-ft/yr (Miller, 1977, p. 25, 33). Thus, total estimated discharge is greater than 12,000 acre- $\mathrm{ft} / \mathrm{yr}$ and is similar to the quantity simulated in the model.

Flow in the Pahrump-Amargosa subregion is generally from recharge areas toward Death Valley (fig. 29), although much of the recharge generated in the Spring Mountains is discharged between the Spring Mountains and Death Valley. In the southern part of the subregion, south of Pahrump Valley, flow is generally westward. Evapotranspiration is simulated in several model cells south of Shoshone (fig. 28), but the quantity is small. The cells correspond to the channel of the Amargosa River, where only small, localized areas of evapotranspiration are mapped by Harrill and others (1988). Increasing the transmissivities in these cells would reduce the simulated evapotranspiration and thereby allow more ground-water flow to Death Valley. Little flow is simulated in the area south of Shoshone because estimated recharge is minor and transmissivities in both model layers are low (fig. 20). Consolidated rocks in this area have low transmissivities because the proportion of carbonate rocks is small (fig. 23; Plume, 1995).

Westward flow is simulated in both model layers from the Spring Mountains to destinations in Pahrump, Shoshone, and Death Valleys (fig. 29). Simulated evapotranspiration and regionalspring discharge in Pahrump Valley is about 15,000 acre- $\mathrm{ft} / \mathrm{yr}$. This total is within the range of 10,000 to 19,000 acre-ft/yr reported by Harrill (1986, p. 46). Another 9,000 acre-ft/yr is simulated as discharging near Shoshone (fig. 28). Estimated subsurface flow from Pahrump Valley to the area near Shoshone is 6,000 to 18,000 acre$\mathrm{ft} / \mathrm{yr}$ (Harrill, 1986, p. 46). The quantity simulated in the model is 10,000 acre-ft/yr, of which about 1,400 acre-ft/yr is simulated as flow from Shoshone into Death Valley.

\section{Ground-Water Flow to Furnace Creek}

Flow to the springs at Furnace Creek, along the east side of Death Valley, has been postu- lated to originate in Ash Meadows, or in Pahrump Valley, with the flow passing through Ash Meadows (Hunt and others, 1966, p. B39, B40), although Winograd and Thordarson (1975, p. C96) asserted that flow from Pahrump Valley to Ash Meadows is unlikely. Discharge through head-dependent flow boundaries in the Furnace Creek area is about 2,900 acre-ft/yr. An additional discharge of 2,600 acre-ft/yr is simulated as evapotranspiration in two adjacent cells, making a total of 5,500 acre$\mathrm{ft} / \mathrm{yr}$. This discharge is only 400 acre-ft more than that estimated by Hunt and others (1966, p. B38).

Flow to springs at Furnace Creek is simulated from recharge areas in the Kawich Range, Pahute Mesa, Yucca Mountain, the Belted Range, and, to a much lesser extent, the Funeral Mountains. Generally, flow is south from the recharge areas to just west of Ash Meadows, then west through the Funeral Mountains. No flow is simulated directly from Ash Meadows to Furnace Creek.

Carbonate rocks crop out in a nearly continuous band in the Funeral Mountains west of Ash Meadows and provide an avenue of flow through the mountains. Postulated sources of spring discharge at Furnace Creek are direct flow from Ash Meadows or downward leakage from the basin fill beneath the central and south-central Amargosa Desert (Winograd and Thordarson, 1975, p. C96). Water in the basin fill may be from spring runoff at Ash Meadows, from southward flow through the Nevada Test Site, or from southeastward flow through the upper Amargosa Desert. The chemistry of water from each of these areas is similar to the water discharged at Furnace Creek (Winograd and Thordarson, 1975, pl. 3).

Although no water is simulated as flowing directly from Ash Meadows to Furnace Creek, model results do not rule out the possibility of underflow between the two spring areas. Transmissivities used in the model are averaged over a large area, and only general trends have been simulated. Although transmissivities could be adjusted to attain underflow from beneath Ash Meadows directly to Furnace Creek, existing data are as yet insufficient to justify such an adjustment.

\section{Ground-Water Flow to Ash Meadows}

Ash Meadows is the largest discharge area in the Pahrump-Amargosa subregion and has been studied for many years because of its proximity to the Nevada Test Site, because of its close relation to Devils Hole (habitat of an endangered species of pupfish), and, more recently, because of hydrologic studies regarding the feasibility of 
nuclear-waste storage at Yucca Mountain. Among the studies discussing flow in the vicinity of Ash Meadows are those of Winograd (1962, 1963), Winograd and Thordarson (1975), Winograd and Pearson (1976), Dudley and Larson (1976), Waddell (1982), Czarnecki and Waddell (1984), Waddell and others (1984), and Dettinger (1989). The most detailed discussion on the possible sources of ground water at Ash Meadows is presented by Winograd and Thordarson (1975, p. C85-C92 and p. C108C113).

Simulated discharge in the vicinity of Ash Meadows totals about $26,000 \mathrm{acre}-\mathrm{ft} / \mathrm{yr}$, including 17,000 acre-ft/yr of regional spring discharge from the lower layer and 9,000 acre-ft/yr as evapotranspiration from the upper layer (fig. 28). The simulated distribution of evapotranspiration approximates the distribution mapped by Harrill and others (1988), except that areas of simulated evapotranspiration extend farther upgradient from the springs, whereas mapped areas extend farther downgradient. Estimated discharge in this area is 24,000 acre-ft/yr (Walker and Eakin, 1963, p. 21-27), including 17,000 acre-ft/yr from regional springs (table 1).

Recharge areas contributing flow to Ash Meadows include mountain ranges as far north as the southern ends of the Kawich and Belted Ranges and as far east as the Pintwater Range and Spring Mountains. The Spring Mountains account for much of the recharge in southern Nevada. Consequently, a large ground-water mound is simulated beneath the mountains, from which flow is radially outward. Northward flow from the Spring Mountains is simulated to the Spotted Range (fig. 29), where the direction changes to westward flow beneath Frenchman Flat and eventually southwestward to Ash Meadows. Flow in the upper layer from recharge in the Pintwater Range is simulated as entering the subregion near Indian Spring Valley.

Subsurface flow from Pahrump Valley, excluding direct flow from the north end of the Spring Mountains, to the adjacent Amargosa Desert also is simulated, but the quantity is only 1,400 acre$\mathrm{ft} / \mathrm{yr}$. None of this ground water is simulated as discharging at Ash Meadows. Instead, the flow moves southwestward toward Death Valley. Estimates of flow between Pahrump Valley and Ash Meadows range from as little as 3,000 to as much as 13,000 acre-ft/yr, as summarized by Winograd and Thordarson (1975, p. C90-C92). However, they concluded that only a small percentage of Ash Meadows discharge may actually originate in Pahrump Valley. They based their conclusion on
(1) the presence of low-permeability rocks between the basins, (2) differences between the quality of water discharging at Ash Meadows and ground water in Pahrump Valley, and (3) the estimated water-level gradient between the two areas.

Most of the water simulated as discharging from Ash Meadows originates in the Spring Mountains. Flow southward from Yucca Flat through the Nevada Test Site to Ash Meadows is about $3,000 \mathrm{acre}-\mathrm{ft} / \mathrm{yr}$ through the lower layer and 1,000 acre-ft/yr through the upper layer. This accounts for about 15 percent of the total simulated discharge at Ash Meadows. Subsurface outflow to Death Valley from the two model cells representing the regional springs at Ash Meadows is only $200 \mathrm{acre}-\mathrm{ft} / \mathrm{yr}$.

The area contributing flow to Ash Meadows differs from that of Winograd and Thordarson (1975, pl. 1 and p. C85-C90) to the east and northeast. They include recharge from the Desert and Sheep Ranges east of the Pintwater Range and subsurface flow from Pahranagat Valley, but do not delineate the northern extent of the area. Their boundary on the east side of the Sheep Range is drawn on the basis of low-permeability clastic rocks exposed along a thrust fault in the southern (and highest) part of the Sheep Range (Winograd and Thordarson, p. C87). More recent evidence (Dettinger, 1989, p. 13) suggests that a thick section of carbonate rocks is present beneath the Sheep Range and that the underlying clastic rocks are sufficiently high in altitude on the west side of the Sheep Range to impede westward flow of water recharging in the Sheep Range. This evidence supports geochemical balances indicating that nearly all recharge generated in the Sheep Range may flow north and east toward Muddy River Springs (Thomas, 1988).

The Desert Range, between the Pintwater and Sheep Ranges, may be a more logical location for a divide between the Death Valley and Colorado River regions. Precambrian and Cambrian clastic rocks are exposed in the central part of the Desert Range (Winograd and Thordarson, 1975, pl. 1). Dettinger (1989, p. 13) noted two areas underlain by relatively thick sequences of carbonate rocks near the boundary between Clark and Lincoln Counties: the Pintwater-Spotted Range area (Guth, 1988) and the Coyote Spring Valley area (Guth, 1988; Wernicke and Axen, 1988, p. 1749). These two areas are connected to a similar area of thick carbonate rocks to the north and may represent the principal conduits for regional flow from east-central Nevada to Ash Meadows and Muddy River Springs (Dettinger, 1989, p. 13). 
Although no flow is simulated in the model from areas north of the Pintwater Range to Ash Meadows, geologic evidence indicates that such flow is possible.

The current boundaries of the deep-flow region are determined from model calibrations based on measured water levels at a few sites and estimated discharges for each hydrographic area. During model calibration, changing the hydraulic properties near any one of the principal discharge areas (for example, Las Vegas Valley, Pahrump Valley, Ash Meadows, and Muddy River Springs) resulted in changed flow quantities at the other discharge areas. Such changes suggest that the flow boundary between the Colorado River and Death Valley regions is sensitive to hydraulic properties near areas of discharge. Because boundaries of flow regions are dependent on flow from recharge areas to discharge areas, changing the flow quantity at a discharge area results in a shift of flow-region boundaries. For example, a five-fold transmissivity increase in two lowerlayer cells representing the regional springs at Ash Meadows increased the simulated discharge at Ash Meadows by about 3,000 acre-ft/yr and decreased the discharge at Muddy River Springs by about 1,400 acre-ft/yr, indicating that the simulated boundary between the two regions shifted eastward. Similarly, a transmissivity increase in five upper-layer cells on the east side of Las Vegas Valley increased evapotranspiration in the valley and reduced the simulated flow to Ash Meadows and Pahrump Valley, suggesting that the flow-region boundary moved westward in the Spring Mountains.

Model results present but one possibility of flow to Ash Meadows. Flow from Pahranagat Valley to Ash Meadows is suggested by Winograd and Friedman (1972, p. 3700), Thomas (1988), and Kirk and Campana (1990). To simulate such flow in the model, transmissivities could be increased between the two areas. However, this would increase the total discharge at Ash Meadows unless some of the flow currently simulated to the springs is diverted elsewhere.

Northward flow from the Spring Mountains may be inhibited by the Las Vegas Valley shear zone (fig. 22). Evidence for this in one area is presented by Winograd and Thordarson (1975, p. C67). If the shear zone does block northward flow, more water from the Spring Mountains may flow toward Las Vegas Valley, and less to Ash Meadows, than is simulated herein. Reducing flow to Ash Meadows would allow for the simulation of flow from the Pahranagat Valley area to Ash Meadows.

In summary, current boundaries of deep-flow regions and subregions are based on limited estimates of water levels and on the distribution of estimated recharge and discharge. The model simulation provides one concept of flow from areas of recharge to areas of discharge. If the estimates of recharge and discharge used in model calibration are grossly incorrect, then the flow boundaries as delineated in this report are also incorrect. Model results suggest that the Death Valley deep-flow region can be divided into subregions that are virtually separate, compartmentalized flow systems. Model results also suggest that estimated discharge at Ash Meadows can be accounted for by flow from the Spring Mountains and from recharge areas in and north of the Nevada Test Site. If water from east-central Nevada also discharges to Ash Meadows, as indicated from geochemical evidence (Winograd and Friedman, 1972, p. 3700; Thomas, 1988), then either the estimates of discharge are too low or some (or all) of the water currently simulated as flowing to Ash Meadows actually flows elsewhere.

\section{COLORADO RIVER REGION}

The Colorado River region, in the southeastern part of the study area (fig. 24A), encompasses about $19,000 \mathrm{mi}^{2}$. It includes four deep-flow subregions in the lower layer-Penoyer, Las Vegas, Virgin River, and White River (fig. 30)-and all or part of 11 shallow-flow regions in the upper layer (fig. 23). Little ground-water flow is simulated between the deep-flow subregions, even though water levels generally decline toward the Virgin and Colorado Rivers.

Las Vegas Valley is the most intensively studied area in the Colorado River region of the study area. A rapidly increasing population since World War II has resulted in severe ground-water overdrafts in the basin-fill aquifers. Several detailed studies have been undertaken to assess the ground-water resources in Las Vegas Valley and to ascertain the changes caused by development (Maxey and Jameson, 1948; Domenico and others, 1964; Malmberg, 1965; Harrill, 1976; Morgan and Dettinger, 1994). Several other studies have been undertaken in an effort to explain the origin of flow from large springs along the course of the White River and at Muddy River Springs (Eakin, 1966; Winograd and Friedman, 
1972; Welch and Thomas, 1984; Thomas, 1988; Kirk and Campana, 1990). These studies, along with hydrologic reconnaissance investigations elsewhere in the region, form the basis for comparison of ground-water flow with the model results.

\section{INFLOW}

Simulated inflow to the Colorado River region is about 207,000 acre-ft/yr, of which recharge to cells in the upper model layer totals about 202,000 acre-ft/yr (table 5). Principal recharge areas include the White Pine, Egan, and Schell Creek Ranges in the north; the Wilson Creek, Bristol, and Quinn Canyon Ranges in the central part; and the Spring Mountains and Sheep Range in the south (fig. 30). Small quantities of recharge are also assigned to several other mountain ranges. In addition, about 5,000 acre-ft/yr enters the region as subsurface flow in both layers from adjacent regions: about 1,000 acre-ft/yr is simulated as subsurface flow to the White River subregion from the Railroad Valley region, about 2,000 acre- $\mathrm{ft} / \mathrm{yr}$ to the Penoyer subregion from the Death Valley region, and about 2,000 acre-ft/yr to the Virgin River subregion from the Bonneville region (table 5).

\section{OUTFLOW}

Simulated outflow from the Colorado River region is about 205,000 acre-ft/yr (table 5). In contrast to the other regions, simulated discharge from regional springs $(97,000$ acre-ft/yr) in the lower model layer exceeds discharge from evapotranspiration ( 91,000 acre-ft/yr) in the upper model layer. Regional-spring discharge is simulated in White River Valley (25,000 acre-ft/yr), at Panaca Warm Spring near Panaca (9,900 acre-ft/yr), in Pahranagat Valley $(24,000$ acre-ft/yr), at Muddy River Springs (37,000 acre-ft/yr), and at Rogers and Blue Point Springs south of Overton (1,200 acre-ft/yr). Major areas of simulated evapotranspiration are in White River in the north, Pahranagat Valley in the central part, and Las Vegas Valley and the Muddy River Springs area in the south (fig. 30). The remaining simulated outflow includes 7,000 acre-ft/yr of leakage to the Virgin River and Lake Mead from the upper layer, and 10,000 acre-ft/yr of subsurface flow in both layers to adjacent regions.

\section{DESCRIPTION OF SUBREGIONS}

\section{PENOYER SUBREGION}

The Penoyer subregion, on the westernmost margin of the Colorado River region (fig. 30), encompasses about $1,200 \mathrm{mi}^{2}$. The deep-flow subregion generally coincides with two shallow-flow regions in the upper model layer (fig. 23). The subregion boundaries do not correspond to the flow-system boundaries delineated by Harrill and others (1988). The subregion includes Penoyer, southern Railroad, and northern Kawich Valleys (fig. 30), whereas Harrill and others classify Penoyer Valley as a hydrologically closed basin and include all of Kawich and southern Railroad Valleys in a flow system that drains toward Death Valley.

Simulated inflow is primarily from recharge assigned to cells in the upper model layer. Recharge totals 12,000 acre-ft/yr, principally in the Kawich, Reville, and Quinn Canyon Ranges (fig. 30 ). The remaining 2,000 acre-ft/yr of inflow is subsurface flow from the Death Valley region, primarily in the upper layer.

Simulated outflow from the subregion (table 5 ) is primarily by evapotranspiration from the upper model layer in southern Railroad Valley $(2,000$ acre-ft/yr) and Penoyer Valley (9,000 acre-ft/yr; fig. 30). These rates are considerably greater than those estimated by Van Denburgh and Rush (1974, p. 24) - 200 acre-ft/yr in southern Railroad Valley and 3,800 acre-ft/yr in Penoyer Valley [the latter is only 60 percent of the 6,400 acre-ft/yr estimated earlier by Eakin and others (1951, p. 156)]. Subsurface flow to the White River subregion of 2,000 acre-ft/yr accounts for the remaining simulated outflow.

In the subregion, low transmissivities (generally less than $0.006 \mathrm{ft}^{2} / \mathrm{s}$ ) are simulated in the lower layer (fig. 20B), whereas higher values $\left(0.006-0.18 \mathrm{ft}^{2} / \mathrm{s}\right)$ are simulated in the upper layer (fig. 20A). Consequently, only 17 percent of the simulated inflow to the subregion is inflow to the lower layer. Most of the flow in the lower layer is simulated as leaking back to the upper layer in Penoyer Valley. Subsurface flow from southern Railroad Valley to Kawich Valley has been suggested by Blankennagel and Weir (1973, p. B20). In contrast, ground-water flow is simulated from southern Railroad Valley and northern Kawich Valleys to Penoyer Valley (fig. 31). Regionally, model results replicate areas of evapotranspiration and regional spring discharge. 
Locally, the model results might be improved by increasing transmissivities in northern Kawich Valley to simulate southward flow from southern Railroad Valley. This might reduce simulated evapotranspiration in Penoyer Valley and increase subsurface flow to the Death Valley region. However, locally changing transmissivities during model calibration did not always result in expected changes in simulated discharge. Observations made during the model calibration indicate that increasing the transmissivities in southern Railroad Valley results in a northward shift of the subregion boundary, with an accompanying increase in simulated flow to the south.

\section{EXPLANATION}

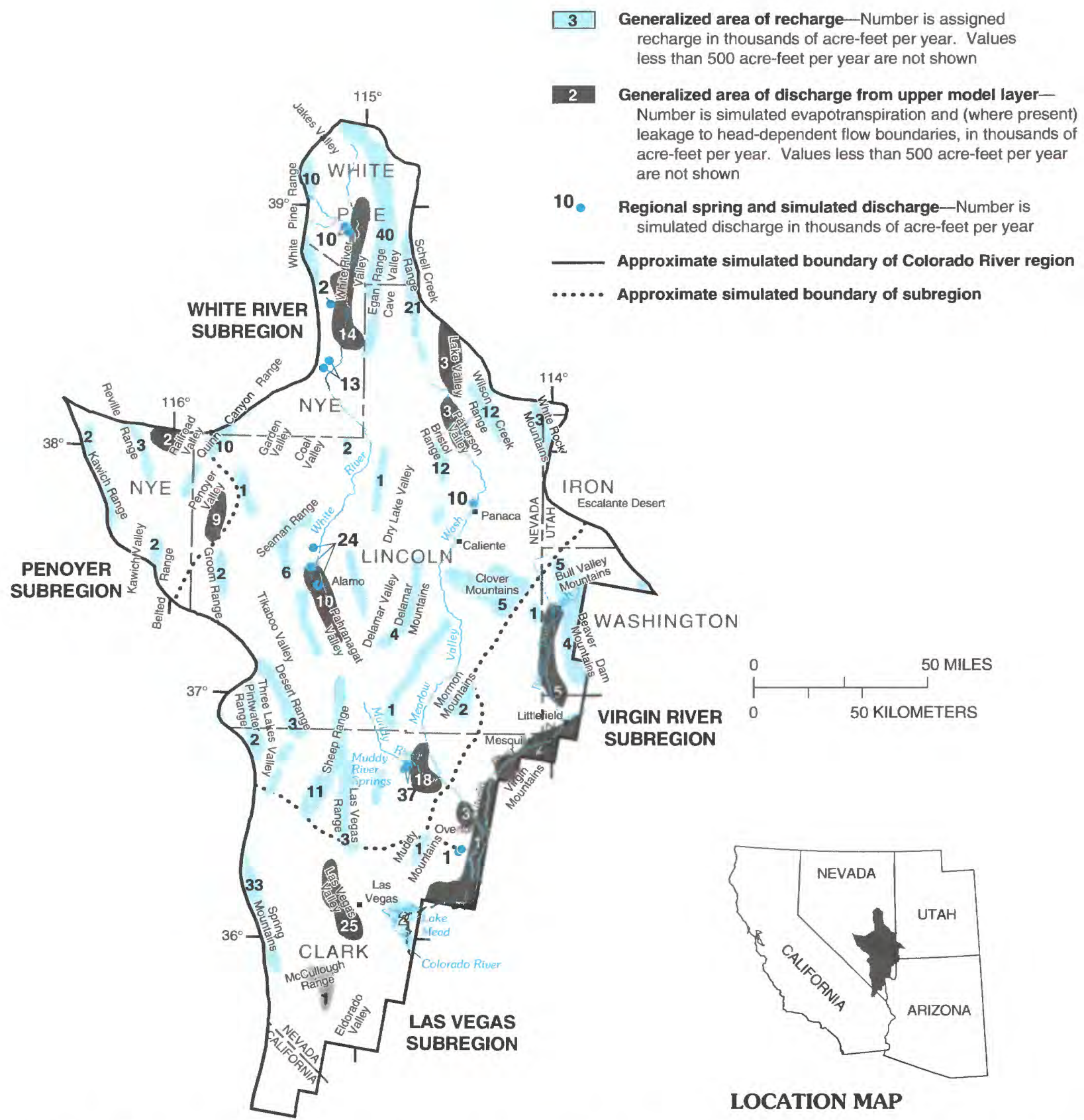

Figure 30.-Areas of assigned recharge, simulated discharge from upper model layer, and simulated discharge from regional springs in Colorado River region. 
TABLE 5.-Simulated ground-water flow budgets, Colorado River region

[All amounts are in acre-feet per year (acre-ft/yr), rounded to nearest 1,000 acre-ft/yr. Amounts of mountain recharge are assigned, as described in text section title "Estimates of Recharge"; all other listed amounts are determined from model simulation]

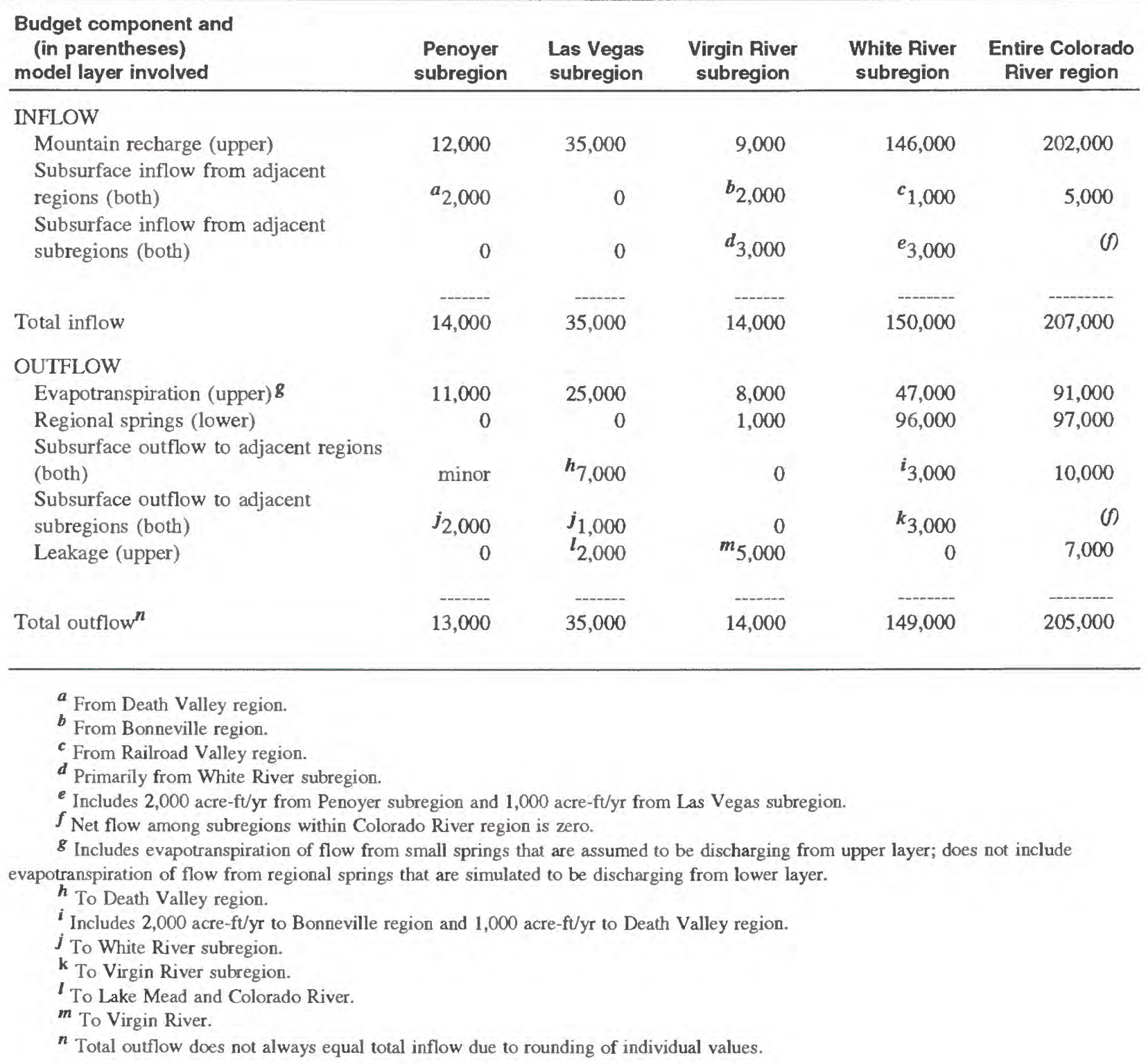

\section{LAS VEGAS SUBREGION}

The Las Vegas subregion, at the southern end of the Colorado River region, encompasses about $3,300 \mathrm{mi}^{2}$. The western boundary of the subregion generally corresponds to a flow-system boundary by Harrill and others (1988). However, the northern boundary does not coincide with their flow-system boundary because they consider flow to the Colorado and Virgin Rivers as one flow system. Thus, their flow system also includes the White River and Virgin River subregions.
Las Vegas Valley, at the northern end of the subregion, is one of the most densely populated areas in the carbonate-rock province, and ground water is an important source of municipal supply. Ground-water withdrawals, which began in the early 1900's, exceed 60,000 acre-ft/yr (fig. 8; Morgan and Dettinger, 1994). The model simulations herein assume predevelopment conditions and, therefore, do not include changes in groundwater flow caused by pumping or by recharge associated with the use of ground water and imported surface water. 
Simulated inflow to the subregion, which consists entirely of recharge assigned to cells in the upper model layer, totals 35,000 acre-ft/yr (table $5)$. All but 2,000 acre-ft/yr of the recharge is from the Spring Mountains, which are the highest in southern Nevada. Estimates of predevelopment recharge to Las Vegas Valley, the principal area of discharge in the subregion, range from 25,000 acre-ft/yr (Malmberg, 1965, p. 57) to about 35,000 acre-ft/yr (Maxey and Jameson, 1948, p. 108). The difference in estimates is due in part to differences in the boundaries selected to define the Las Vegas Valley hydrographic basin.

Simulated outflow from the subregion is 35,000 acre-ft/yr, of which evapotranspiration (including spring discharge) from the upper model layer in Las Vegas Valley is 25,000 acre-ft/yr (table 5). Estimates of predevelopment discharge are assumed to equal those of predevelopment recharge. Thus, simulated evapotranspiration is at the low

\section{EXPLANATION}

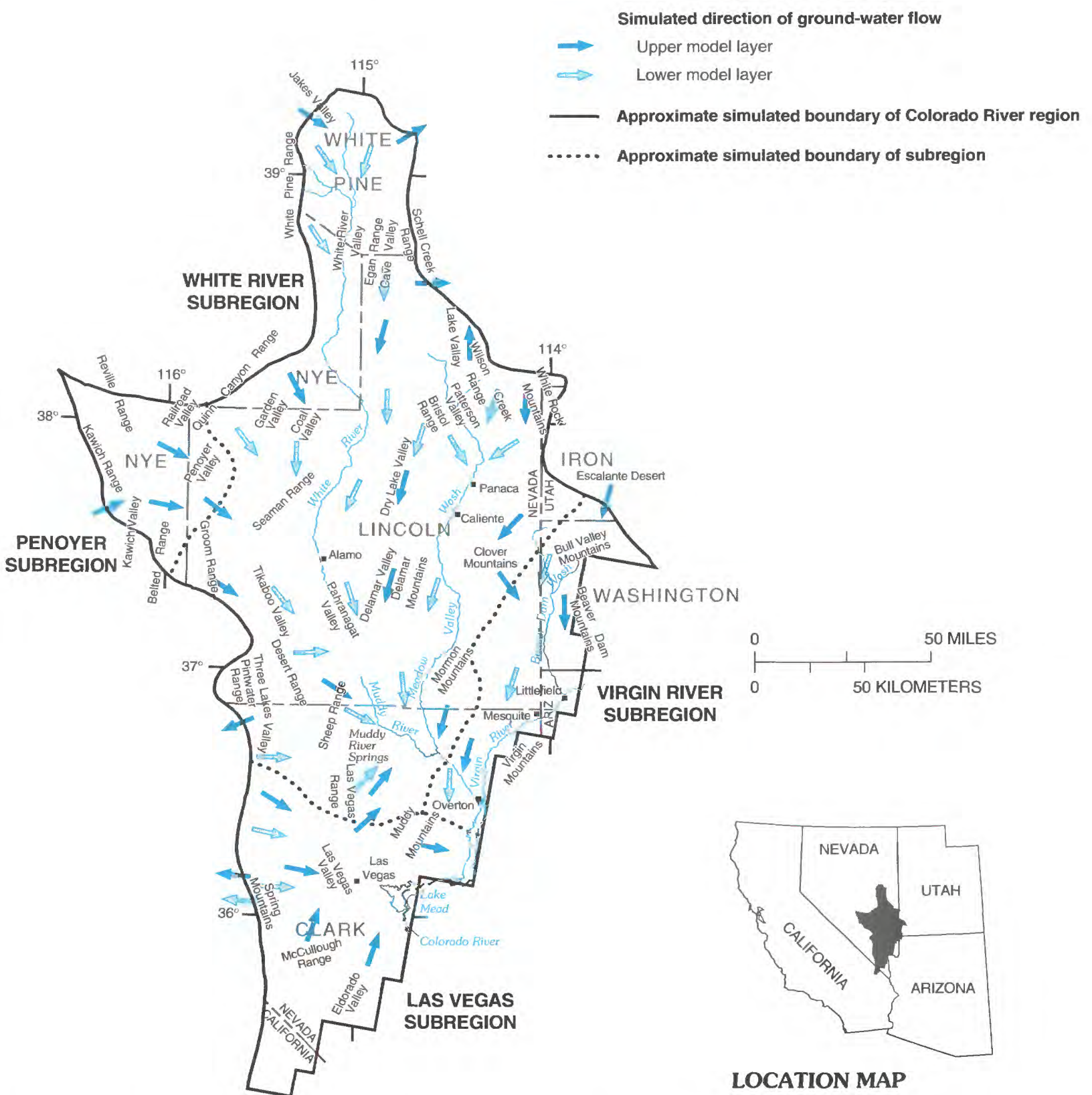

Figure 31.-Simulated direction of ground-water flow for both upper and lower model layers in Colorado River region. 
end of the range of 25,000 to 35,000 acre-ft/yr estimated for predevelopment discharge from Las Vegas Valley. Only 2,000 acre-ft/yr is simulated as subsurface leakage to Lake Mead and the Colorado River in the upper layer. This total includes about 1,000 acre-ft/yr from Las Vegas Valley and another 1,000 acre-ft/yr from the area south of Las Vegas Valley. The simulated quantity of leakage from Las Vegas Valley is similar to the 1,200 acre-ft/yr simulated by Harrill (1976, p. 50) and the 2,000 acre-ft/yr simulated by Morgan and Dettinger (1994). The quantity of eastward subsurface outflow from the area south of Las Vegas Valley is comparable to the 1,100 acre-ft/yr from Eldorado Valley estimated by Rush and Huxel (1966, p. 17). Discharge also is simulated to Lake Mead southeast of the Muddy Mountains, but the combined flow in several cells there is less than 500 acre-ft/yr.

Subsurface flow to the White River subregion and the Death Valley subregion account for the remaining outflow from the Las Vegas subregion. A small quantity of outflow (less than 1,000 acre$\mathrm{ft} / \mathrm{yr}$ ) is simulated to the White River subregion from an area near the Muddy Mountains. Subsurface flow is simulated to the PahrumpAmargosa subregion of the Death Valley deep-flow region along the crest of the Spring Mountains, where boundaries of both the shallow-flow and deep-flow regions are drawn across model cells. Because cells are not subdivided when determining flow budgets for each subregion, those along the crest of the Spring Mountains are assigned to the Las Vegas subregion. As a result, subsurface outflow is used to account for the westward component of flow from the crest. Of the 7,000 acre-ft/yr simulated to the Pahrump-Amargosa subregion, about half is in the lower layer.

Simulated flow in the subregion is mostly in the upper model layer. About 76 percent of the total inflow to the subregion is simulated through the upper layer. Transmissivities in the upper layer typically range from 0.006 to $0.18 \mathrm{ft}^{2} / \mathrm{s}$ (fig. $20 \mathrm{~A}$ ), whereas in the lower layer, they range from 0.0006 to $0.006 \mathrm{ft}^{2} / \mathrm{s}$ (fig. $20 B$ ). In Las Vegas Valley, the transmissivities in the upper layer encompasses the range of 0.02 to $0.12 \mathrm{ft}^{2} / \mathrm{s}$ for basin fill reported by Harrill (1976, p. 15, 16) and Morgan and Dettinger (1994). Low transmissivities in the lower layer south and east of Las Vegas Valley correspond to an area where carbonate rocks are thin or isolated (Dettinger, 1989, p. 14) and where outcrops in the mountains are generally rocks of low permeability (fig. 23; Plume, 1995).

\section{VIRGIN RIVER SUBREGION}

The Virgin River subregion, on the east side of the Colorado River region (fig. 30), encompasses about 2,000 $\mathrm{mi}^{2}$. Simulated inflow totals 14,000 acre- $\mathrm{ft} / \mathrm{yr}$ (table 5). Recharge assigned in the upper layer is about 9,000 acre-ft/yr, primarily in the Bull Valley Mountains and Beaver Dam Mountains. In addition, 2,000 acre- $\mathrm{ft} / \mathrm{yr}$ is simulated as subsurface inflow from the Bonneville deepflow region at the southern end of the Escalante Desert (of which 800 acre-ft/yr is in the lower layer), and about 3,000 acre-ft/yr is simulated as flow from the White River subregion, mostly in the upper layer.

Simulated outflow from the subregion totals about 14,000 acre-ft/yr, of which 8,000 is evapotranspiration in the upper model layer, 5,000 is leakage to the Virgin River from the upper layer and 1,200 is discharge to Rogers and Blue Point Springs south of Overton in the lower layer (table 5 -value in table differs slightly from table 1 due to rounding). Simulated evapotranspiration in Beaver Dam Wash is about 5,000 acre-ft/yr (fig. 30 ). An additional 1,200 acre-ft/yr is simulated as leakage at the head-dependent flow boundary cell corresponding to the confluence of Beaver Dam Wash and the Virgin River. Thus, total simulated discharge along Beaver Dam Wash is 6,200 acre$\mathrm{ft} / \mathrm{yr}$. Estimated ground-water discharge in Beaver Dam Wash includes about 150 acre-ft/yr as evapotranspiration and 3,600 acre-ft/yr as leakage to the Virgin River for a total discharge of about 3,800 acre-ft/yr (Glancy and Van Denburgh, 1969, p. 36, 47). Evapotranspiration simulated along the lower Muddy River near Overton is about 3,000 acre-ft/yr-considerably less than the 11,000 acre-ft/yr estimated by Rush (1968b, p. 35 ; he refers to the area as lower Moapa Valley). Much of the ground-water recharge in this area is from downward seepage of streamflow in the Muddy River, and little is thought to enter the area either as direct recharge from precipitation or as underflow from adjacent areas (Rush, 1968b, p. 23-26). Secondary recharge to the upper model layer of spring flow from Muddy River Springs is not simulated in the model and may account for the difference between simulated and estimated evapotranspiration along the lower Muddy River.

The Virgin River below Beaver Dam Wash also is simulated as a discharge area for ground water flowing from recharge areas north of the river (fig. 31). Some ground water probably seeps into the Virgin River from recharge areas northwest 
and southeast of the river, but the location and magnitude of this seepage is unknown (Glancy and Van Denburgh, 1969, p. 36). The river reach from Beaver Dam Wash to Lake Mead is generally a losing stream that supplies water to underlying aquifers (Glancy and Van Denburgh, 1969, p. 37). Much of the seepage from the river in this reach is to the adjacent and underlying alluvium, where most of it is discharged by evapotranspiration. Shallow ground water not lost to evapotranspiration moves parallel to the river, and therefore is not included in the model because it is considered local flow.

The principal contribution of ground water to the Virgin River in or near the modeled area is about 50,000 acre-ft/yr of moderately saline water from springs in the channel of the river along a 7-mile reach near Littlefield, Arizona (Glancy and Van Denburgh, 1969, p. 33, 36). These springs were not specifically included in the model because they are at the model boundary. Furthermore, most of the water discharging at the springs is Virgin River water that seeps into the underlying alluvium and carbonate rocks 9 to $15 \mathrm{mi}$ upstream and local recharge of precipitation (Trudeau and others, 1983, p. 328).

Transmissivities in both model layers generally range from 0.0006 to $0.006 \mathrm{ft}^{2} / \mathrm{s}$. Because transmissivities are nearly the same for both layers, about half of the recharge is simulated as flow to the lower layer. Discharge from the lower layer is primarily to the upper layer along Beaver Dam Wash, the Muddy River, and the Virgin River. Transmissivities assigned to model cells in the vicinity of Beaver Dam Wash perhaps could be increased slightly to reduce the quantity of discharge as evapotranspiration along the wash and increase upward leakage to the Virgin River. Another alternative is to increase the vertical conductance in the head-dependent flow boundary used to simulate leakage to the river.

A zone of higher transmissivities is simulated along the western margin of the subregion, from Rogers and Blue Point Springs (fig. 11, No. 3) northward to an area between the Mormon Mountains and Beaver Dam Wash (fig. 20). Transmissivities in this zone are based on calibration of spring discharge at Rogers and Blue Point Springs. During model calibration, transmissivities in the lower layer were increased in cells at and north of Rogers and Blue Point Springs. The springs issue from carbonate rocks near the contact with basin fill. Recharge in the adjacent Muddy Mountains (fig. 31) is insufficient to supply all the flow to the springs. Simulated flow to the springs is from the northern part of the subregion. Ground water could potentially flow from Muddy River Springs to Rogers and Blue Point Springs because land surface at the latter springs is about 200 feet less in altitude than that at Muddy River Springs (Thomas and others, 1986, pl. 2). However, differing isotope values for the two spring systems (Thomas and others, 1991, p. 14, 19) and the presence of low-permeability rocks near land surface downgradient from Muddy River Springs (Michael D. Dettinger, U.S. Geological Survey, oral commun., 1987) suggest that underflow from those springs is an unlikely source.

\section{WHITE RIVER SUBREGION}

The White River subregion, the largest delineated in the Colorado River region, encompasses about $12,800 \mathrm{mi}^{2}$ (fig. 30). The subregion boundary generally corresponds to a shallow-flow-region boundary delineated in the upper model layer (compare figs. 23 and 24). The White River subregion extends farther east and west of the flow system defined by Eakin (1966), but does not extend as far north. The subregion includes Tikaboo Valley and the Pintwater and Desert Ranges to the west, and Lake and Patterson Valleys, Meadow Valley Wash, and western Escalante Desert to the east. The northern boundary extends to southern Jakes Valley, whereas Eakin includes all of Jakes Valley as well as Long Valley (Long Valley is included in the Railroad Valley deep-flow region; see figure 34). The northern part of the flow system delineated by Harrill and others (1988) is the same as Eakin's. Their flow system differs to the east and south because they extend their eastern boundary to the Virgin and Colorado Rivers and their southern boundary to the boundary of the study area.

Inflow to the subregion totals 150,000 acre$\mathrm{ft} / \mathrm{yr}$, of which recharge assigned to model cells in the upper model layer is 146,000 acre-ft/yr (table 5); the latter is more than 70 percent of the total for the entire Colorado River region. Principal areas of recharge include the White Pine, Egan, and Schell Creek Ranges in the northern part of the subregion; the Wilson Creek, Bristol, and Quinn Canyon Ranges in the central part; and the Sheep Range in the southern part (fig. 30). The remaining inflow is simulated subsurface flow from adjacent regions and subregions: about 1,000 acre-ft/yr from the Railroad Valley region, 2,000 acre-ft/yr from the Penoyer subre- 
gion, and 1,000 acre-ft/yr from the Las Vegas subregion (table 5).

Outflow from the subregion is primarily discharge to regional springs in the lower model layer, which totals 96,000 acre-ft/yr. Discharge as evapotranspiration from the upper layer is only 47,000 acre-ft/yr. Discharge is simulated in three general areas of the subregion that correspond to mapped areas of ground-water evapotranspiration and to regional spring discharge (Harrill and others, 1988). The three areas are: Patterson and southern Lake Valleys and Panaca Warm Spring in the upper Meadow Valley Wash drainage, White River and Pahranagat Valleys in the White River drainage, and Muddy River Springs (fig. 30). Subsurface outflow to the Bonneville region simulated through the upper layer from the Egan, Schell Creek, and Wilson Creek Ranges (fig. 31) totals about 2,000 acre-ft/yr (table 5). An additional 3,000 acre-ft/yr is simulated as outflow to the Virgin River subregion, and 1,000 acre-ft/yr flows to the Death Valley region near the Pintwater Range (table 5; fig. 31).

Ground-water flow in the subregion is generally from north to south in both model layers (fig. 31 , paralleling the Meadow Valley Wash and White River drainages. Simulated flow is west to east near the Sheep Range. More ground-water flow is simulated in the lower layer in the White River subregion than in any other in the study area. Ground-water flow in most other subregions is generally in the upper layer from recharge areas in the mountain ranges to discharge areas in adjacent valleys. In contrast, about 69 percent of the total inflow to the subregion is simulated as inflow to the lower layer. Downward flow from the upper layer to the lower layer totals 113,000 acre-ft/yr. Discussion of flow and comparison of simulated to estimated discharge is separated into three areas-flow along the Meadow Valley Wash and White River drainages, and flow to Muddy River Springs.

Ground-water flow in the lower model layer is simulated from southern Lake Valley into Patterson Valley, then southward to Panaca (fig. 31 ). Recharge areas contributing flow to Panaca Warm Spring are primarily the Bristol and Wilson Creek Ranges. Overall, simulated discharge in Patterson Valley and at Panaca Warm Spring is about 13,000 acre- $\mathrm{ft} / \mathrm{yr}$, which is greater than the 8,500 acre-ft/yr estimated by Rush $(1964$, p. 19, 22). Minor quantities of evapotranspiration (totaling about 3,000 acre-ft/yr), which have been estimated elsewhere along the axis of Meadow Val- ley Wash, are not simulated in the model. Simulated evapotranspiration in southern Lake Valley is 3,000 acre-ft/yr. Not all of the simulated discharge in Lake Valley is included in the White River subregion because the valley is bisected by the boundary between the Colorado River and Bonneville regions. When the additional 6,000 acre$\mathrm{ft} / \mathrm{yr}$ of evapotranspiration simulated in northern Lake Valley is added to that in southern Lake Valley, total simulated discharge in Lake Valley is approximately the same as the 8,500 acre-ft/yr estimated by Rush and Eakin (1963, p. 13).

South of Panaca, flow is toward Muddy River Springs (fig. 31). Additional flow is added from recharge areas in the Clover, Delamar, and Mormon Mountains (fig. 30). A total of 13,000 acre$\mathrm{ft} / \mathrm{yr}$ of underflow is simulated from lower Meadow Valley Wash to the area near Muddy River Springs, of which 9,000 acre-ft/yr is simulated in the upper layer. Estimated shallow underflow from Meadow Valley Wash into the Muddy River drainage just downstream from Muddy River Springs is 7,000 acre-ft/yr (Rush, 1968b, p. 26, 27).

Simulated ground-water flow along the White River is generally southward in both model layers from White River Valley to Pahranagat Valley, then southeast to Muddy River Springs. This flow is consistent with water levels in the area (Eakin, 1966, p. 258; Thomas and others, 1986). Less ground-water flow is simulated through Jakes Valley into White River Valley than was estimated by Eakin (1966, p. 265). He estimated that about 25,000 acre-ft/yr may enter the White River Valley from as far north as Long Valley (location shown on figure 34). Although recharge in mountains adjacent to Jakes Valley is included herein, only 7,000 acre-ft/yr is simulated as underflow from the Jakes Valley drainage basin into the upper end of White River Valley, and no flow is simulated from Long Valley. Simulated flow to White River Valley is from the White Pine and Egan Ranges. Discharge along the White River includes about 25,000 acre-ft/yr from three groups of regional springs simulated in the lower layer near the axis of the valley and 14,000 acre-ft/yr from evapotranspiration simulated in the upper layer (fig. 30). Evapotranspiration from the upper layer includes the flow of small springs not considered part of the regional group in the lower layer. Simulated flow to the northern group of springs and to Mormon Hot Spring is from the Egan Range, whereas flow to the southern group is from both the White Pine and Egan Ranges. Estimated discharge in White River Valley is 
37,000 acre-ft/yr (Eakin, 1966, p. 261), which is only 2,000 acre-ft/yr less than the total simulated discharge from regional springs and evapotranspiration.

Simulated underflow from White River Valley and adjacent Cave Valley (fig. 31) to the south is about 27,000 acre- $\mathrm{ft} / \mathrm{yr}$, which is 13,000 acre$\mathrm{ft} / \mathrm{yr}$ less than that estimated by Eakin (1966, p. 265). This underflow is toward Pahranagat Valley, where discharge from three regional springs in the lower layer is 24,000 acre- $\mathrm{ft} / \mathrm{yr}$ and evapotranspiration in the upper layer is 10,000 acre$\mathrm{ft} / \mathrm{yr}$. Estimated spring flow in Pahranagat Valley is about 25,000 acre-ft/yr (table 1; Eakin, 1966, p. 261), nearly all of which is consumed by evapotranspiration in the valley. Although simulated discharge from springs is nearly the same as the reported spring flow, total discharge from Pahranagat Valley is 9,000 acre-ft/yr more than previously reported. Flow to the northern two springs in Pahranagat Valley is simulated from the White Pine, Egan, and Schell Creek Ranges. Flow to the southern spring (Hiko Spring of Thomas and others, 1986, pl. 2) is simulated from the Quinn Canyon, Seaman, and Schell Creek Ranges.

Simulated underflow from Pahranagat Valley and adjacent Tikaboo Valley (fig. 31) to Muddy River Springs is about 24,000 acre-ft/yr. This flow is about 11,000 acre-ft/yr less than the 35,000 acre-ft/yr estimated as underflow from Pahranagat Valley by Eakin (1966, p. 265). Tikaboo Valley was not included in his conceptualization of flow to Muddy River Springs. More recent studies based on geology, water levels, and deuterium concentrations of water from regional springs in Pahranagat Valley, at Muddy River Springs, and at Ash Meadows (location shown in figure 28) indicate that some ground water from within or near Pahranagat Valley may flow southwest through northern Tikaboo Valley to the regional springs in Ash Meadows (Winograd and Friedman, 1972; Thomas, 1988; Dettinger, 1989; Kirk and Campana, 1990). Estimates of underflow to Ash Meadows range from about 4,000 acre-ft/yr (Kirk and Campana, 1990 , p. 385) to 7,000 acre-ft/yr (Thomas, 1988). Perhaps flow in southern Tikaboo Valley is toward the Muddy River Springs, whereas flow in northern Tikaboo Valley is toward Ash Meadows. Such a possibility is suggested by Harrill and others (1988, pl. 2). Although no flow is simulated from Pahranagat Valley to Ash Meadows, such flow might be simulated by increasing transmissivities between the two places. However, to simulate the estimated spring flow at Ash Meadows, some of the flow from the Spring Mountains to Ash Meadows would need to be diverted either to Las Vegas Valley or Pahrump Valley by decreasing transmissivities in model cells at the north end of the Spring Mountains.

Ground-water flow in the subregion that is not discharged upgradient from the Muddy River Springs is discharged as regional spring flow in the lower layer or as evapotranspiration in the upper layer. Simulated spring flow at Muddy River Springs is 37,000 acre-ft/yr and evapotranspiration along the Muddy River from the springs to the confluence with Meadow Valley Wash is about 18,000 acre-ft/yr. The measured aggregate spring flow is about 36,000 acre-ft/yr (Eakin, 1966, p. 261). The reach of the Muddy River between its source at the springs and Lake Mead (fig. 31) is perennial, but only part of the flow reaches Lake Mead. The average annual flow of the Muddy River near its confluence with Lake Mead is about 6,600 acre-ft/yr, which is based on a 12-year period, 1979-83 and 1985-91 (Garcia and others, 1992, p. 72). Much of the streamflow is consumed by evapotranspiration from phreatophytes and irrigated crops or is used for industrial and public supply. A small percentage of the streamflow may seep back into the ground.

Simulated ground-water discharge near Muddy River Springs is about 19,000 acre-ft/yr more than estimated. Perhaps some or all of extra discharge can be accounted for in the uncertainty of estimated evapotranspiration along the river. Another possibility is that some ground water flows through consolidated rocks beneath the river to discharge into Lake Mead. This does not seem likely, however, because low-permeability rocks that are near land surface downstream from the springs probably inhibit significant underflow to the lake (Michael D. Dettinger, U.S. Geological Survey, oral commun., 1987).

Simulated upper-layer flow to the area of evapotranspiration at Muddy River Springs includes: 9,000 acre-ft/yr from Meadow Valley Wash; 5,000 acre-ft/yr from the southern Sheep Range; 3,000 acre-ft/yr from Pahranagat and Tikaboo Valleys and the northern Desert, Pintwater, and Sheep Ranges; and 1,000 acre-ft/yr from the Las Vegas subregion. Simulated flow in the lower layer to Muddy River Springs is mainly underflow from Pahranagat and Tikaboo Valleys, and the Sheep, Las Vegas, and southern Desert Ranges. Contributions to regional springs include: 23,000 acre$\mathrm{ft} / \mathrm{yr}$ from Pahranagat and Tikaboo Valleys; 8,000 
acre-ft/yr from the Sheep, Las Vegas, and southern Desert Ranges; 4,000 acre-ft/yr from Meadow Valley Wash; and 2,000 acre-ft/yr from Delamar Valley.

The sources of water discharging at Muddy River Springs simulated in the model differs from the sources described by Eakin (1966, p. 265). Using imbalances in estimated water budgets for hydrographic areas north of the springs, he estimated only 2,000 acre-ft/yr of flow from the Sheep Range; the rest was ground-water flow through Pahranagat and Delamar Valleys from recharge areas to the north. A difference in concentrations of the deuterium isotope between spring water in Pahranagat Valley and at Muddy River Springs suggests that not all the discharge at Muddy River Springs is from Pahranagat Valley (Winograd and Friedman, 1972). Deuterium concentrations in water from Muddy River Springs are nearly the same as those in high-altitude springs in the Sheep Range and Spring Mountains, which led Winograd and Friedman (1972, p. 3705) to propose that the principal source of water to the Muddy River Springs is the Sheep Range, the Spring Mountains, or both. On the basis of chemical balances of ground water, Thomas (1988) proposed that nearly all recharge in the Sheep Range may discharge at Muddy River Springs and that ground water beneath the southernmost reach of Meadow Valley Wash may also flow to the springs. Similar conclusions were reported by Kirk and Campana (1990), except they did not suggest as much flow from the Sheep Range to the Muddy River Springs. Because of (1) lack of knowledge regarding the extent of the carbonate-rock aquifers contributing flow to Muddy River Springs, (2) lack of hydraulic properties and water-level gradients in the aquifers, and (3) uncertainties in deuterium concentrations over time and at the different source areas, several areas remain candidate sources of flow to the Muddy River Springs.

Simulated flow to the regional springs is sensitive to the distribution of transmissivities in the lower layer. During model calibration, transmissivities in the lower layer were increased along an axis that generally corresponds to the location of springs in White River and Pahranagat Valleys, and at Muddy River Springs. Transmissivities for the lower layer generally range from 0.006 to $0.18 \mathrm{ft}^{2} / \mathrm{s}$, but in White River Valley and near Muddy River Springs the values range from 0.18 to $0.66 \mathrm{ft}^{2} / \mathrm{s}$ (fig. $20 \mathrm{~B}$ ). The highest transmissivities are concentrated near regional springs; this may be related to locally high flow rates that enhance or maintain openings in the carbonate rocks (Dettinger, 1989, p. 16). Eakin (1966, p. 251) estimated a regional transmissivity value of 200,000 (gal/day)/ft (equivalent to about $0.3 \mathrm{ft}^{2} / \mathrm{s}$ ) on the basis of estimated flow across three vertical sections. The zone of higher transmissivities in the lower layer (fig. 25), which acts as a drain for ground water from adjacent areas, generally corresponds to an area of thick carbonate rocks that may be considered the principal aquifers in central and southern Nevada (Dettinger, 1989, p. 13).

\section{BONNEVILLE REGION}

The Bonneville region, in the northeastern part of the study area (fig. 24), encompasses about $39,000 \mathrm{mi}^{2}$-largest of the five regions. It includes six deep-flow subregions in the lower model layerEscalante, Spring-Steptoe, Ruby, Clover-Independence, Utah Lake, and Great Salt Lake Desert (fig. 32)-and all or part of 23 shallow-flow regions in the upper layer (fig. 23). Ground-water flow is from recharge areas in the mountains to topographically low parts of basins within each subregion. Little flow is simulated between adjacent subregions, even though water levels in most of the Bonneville region generally decline toward the Great Salt Lake Desert or Great Salt Lake.

\section{INFLOW}

Inflow to the Bonneville region totals about 889,000 acre-ft/yr (table 6), which is considerably more than inflow to the other four deep-flow regions. Recharge assigned to cells in the upper model layer, which constitutes most of the inflow, totals about 855,000 acre-ft/yr. The eastern boundary of the flow region is along mountain ranges that supply large quantities of water to both the southeastern Great Salt Lake area and the Sevier Desert area (fig. 32). Other principal recharge areas include fault-block mountains in extreme eastern Nevada and western Utah. Subsurface flow in both layers from adjacent regions, which totals about 34,000 acre-ft/yr, accounts for only 4 percent of the inflow to the Bonneville region. Much of the subsurface inflow is from the upper Humboldt River region, where about 25,000 acre$\mathrm{ft} / \mathrm{yr}$ is simulated along the Ruby Mountains and East Humboldt Range; another 5,000 acre-ft/yr is simulated from the Colorado River region, and 4,000 acre- $\mathrm{ft} / \mathrm{yr}$ is from the Railroad Valley region. 
Inflow from the upper Humboldt River region is simulated along the crest of the Ruby Mountains, where boundaries of both the shallow-flow and deep-flow regions are drawn across model cells. Because cells are not subdivided when determin- ing flow budgets for each region, those along the crest of the mountains are assigned to the upper Humboldt River region. As a result, subsurface inflow is used to account for the eastward component of flow from the crest.

\section{EXPLANATION}

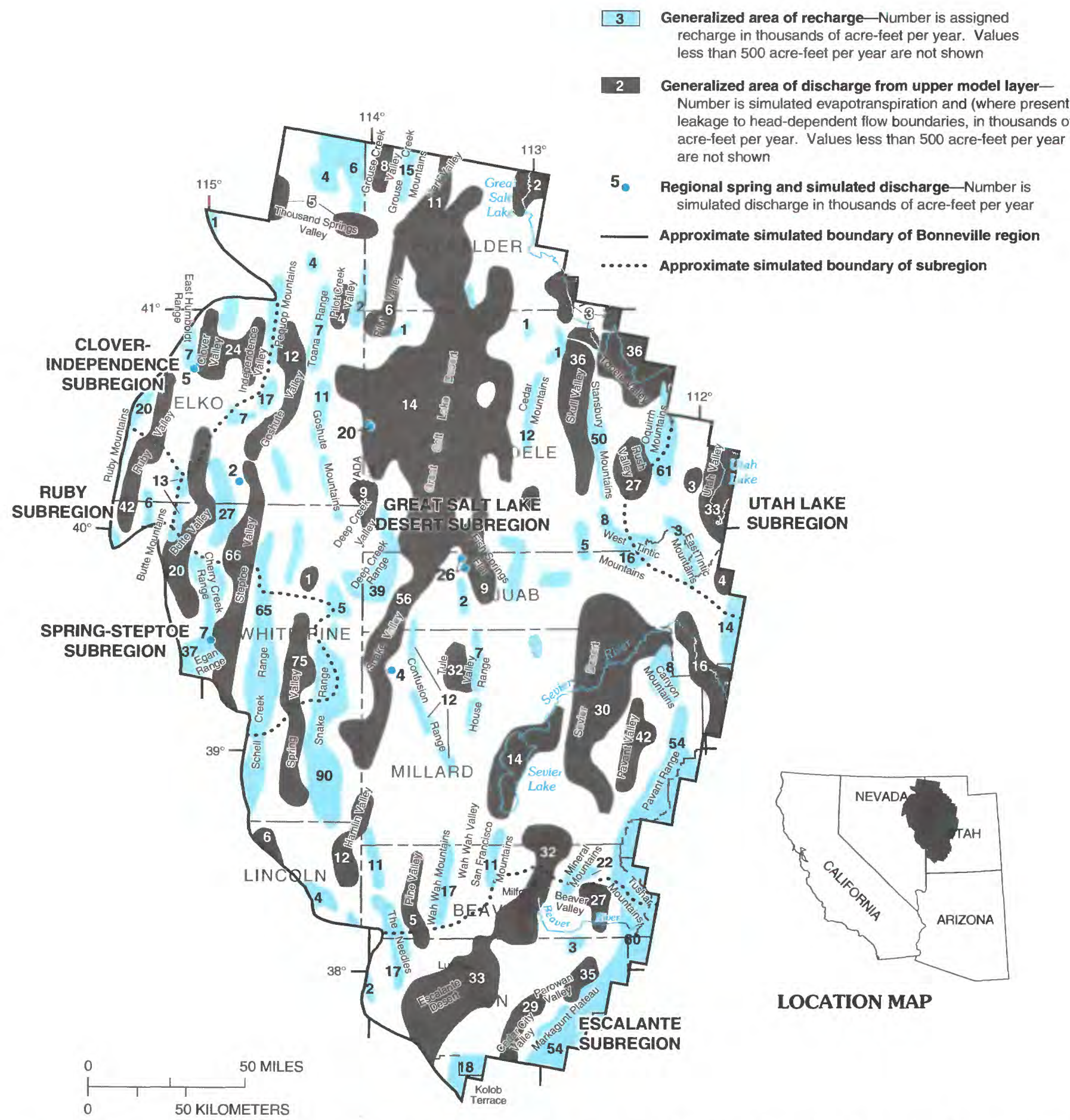

FIgURE 32.-Areas of assigned recharge, simulated discharge from upper model layer, and simulated discharge from regional springs in Bonneville region. 


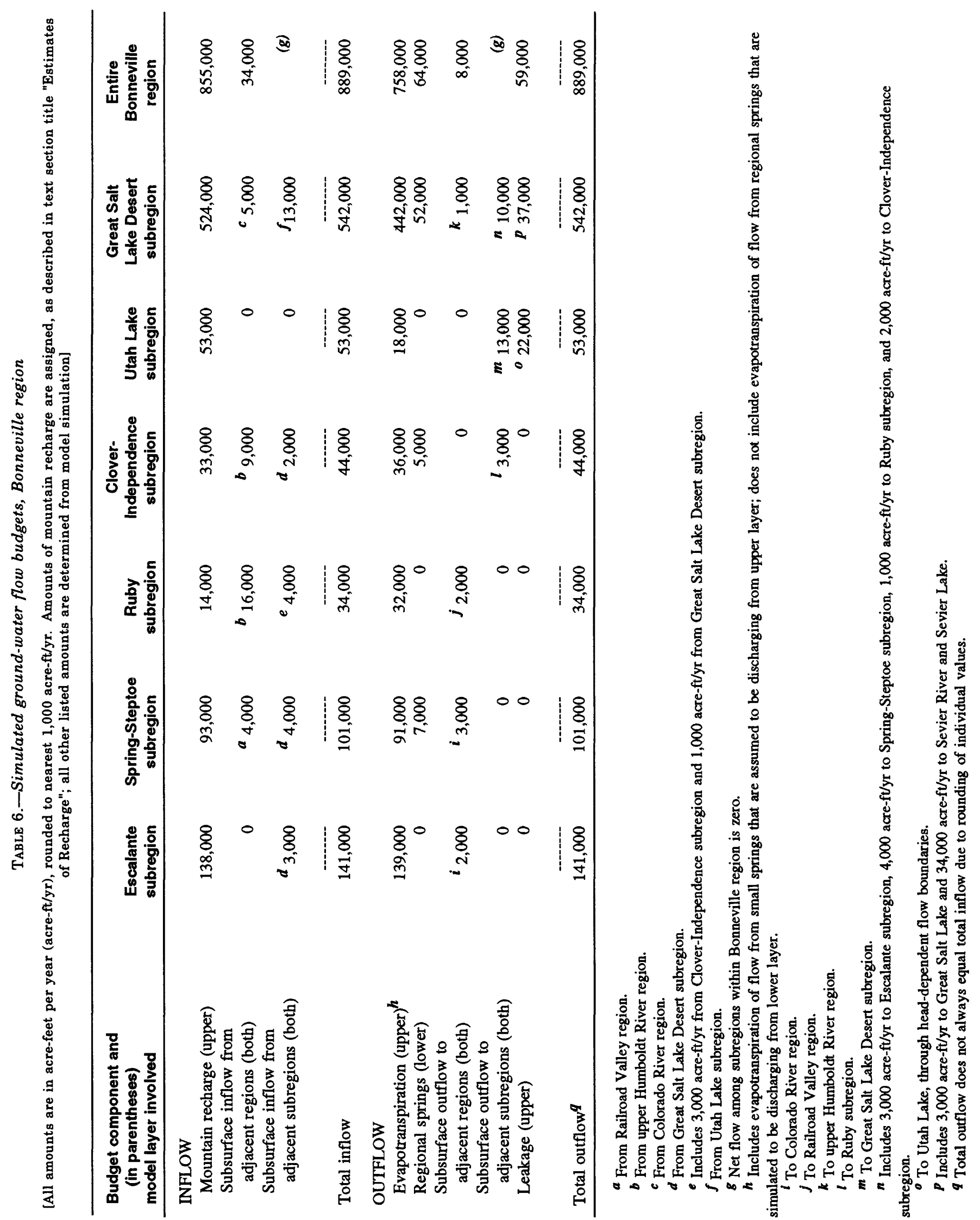




\section{OUTFLOW}

Simulated outflow from the Bonneville region totals 889,000 acre-ft/yr and includes discharge as evapotranspiration and leakage to Utah Lake, Great Salt Lake, Sevier River, and Sevier Lake from the upper layer; discharge to regional springs in the lower layer; and subsurface flow to adjacent regions in both layers (table 6). Many areas of discharge are simulated in the Bonneville region (fig. 32). Large parts of the region are occupied by three deserts-the Great Salt Lake Desert in the north, the Sevier Desert in the middle, and the Escalante Desert in the south-in which considerable ground water is discharged. Simulated evapotranspiration for the entire region is 758,000 acre-ft/yr, which represents about 85 percent of the total outflow. The remaining outflow is to regional springs $(64,000 \mathrm{acre}-\mathrm{ft} / \mathrm{yr})$, to headdependent flow boundaries representing leakage to surface water bodies $(59,000 \mathrm{acre}-\mathrm{ft} / \mathrm{yr})$, and to adjacent regions $(8,000 \mathrm{acre}-\mathrm{ft} / \mathrm{yr})$.

\section{DESCRIPTION OF SUBREGIONS}

\section{ESCALANTE SUBREGION}

The Escalante deep-flow subregion, in the southern part of the Bonneville region (fig. 32), encompasses about $4,000 \mathrm{mi}^{2}$. The subregion approximately coincides with three shallow-flow regions (compare figs. 23 and $24 B$ ). It also coincides with the southern half of a flow system delineated by Harrill and others (1988) that includes the Sevier Desert. Simulated ground-water flow in the subregion is from recharge areas in the mountain ranges to discharge areas in adjacent valleys. Inflow to the subregion totals about 141,000 acre-ft/yr. Recharge assigned to cells in the upper model layer is 138,000 acre- $\mathrm{ft} / \mathrm{yr}$ (table 6 ) and accounts for nearly all the inflow. The remaining 3,000 acre-ft/yr of simulated inflow is subsurface flow from the Great Salt Lake Desert subregion, primarily in the upper layer. Principal recharge areas include the Tushar Mountains and Markagunt Plateau on the east side, Kolob Terrace on the south side, and The Needles on the west side (fig. 32). The mountains on the east side of the subregion generally have more precipitation and runoff than most mountains in the interior of the overall study area.

Outflow from the subregion is mostly evapotranspiration from the upper model layer. Simu- lated evapotranspiration in the subregion is about 139,000 acre-ft/yr (table 6), mostly in Beaver Valley, the southern half of the Milford area, Parowan and Cedar City Valleys, and the Escalante Desert (fig. 32). Areas of simulated evapotranspiration generally coincide with mapped areas of groundwater evapotranspiration (Harrill and others, 1988). About 2,000 acre-ft/yr is simulated as subsurface flow to the Colorado River region, of which about 800 acre-ft/yr is from the lower layer.

Most simulated flow in the Escalante subregion is in the upper model layer. About 88 percent of the total inflow to the subregion is simulated through the upper layer. Transmissivities in the lower layer are generally less than $0.006 \mathrm{ft}^{2} / \mathrm{s}$ except beneath the Escalante Desert (fig. $20 B$ ), whereas values in the upper layer generally exceed $0.006 \mathrm{ft}^{2} / \mathrm{s}$ (fig. $20 \mathrm{~A}$ ). Ground-water flow is from the Tushar Mountains and Markagunt Plateau on the east side toward the Escalante Desert and southern Milford area (fig. 33). However, much of the simulated flow is discharged in Beaver, Parowan, and Cedar City Valleys (fig. 32). Simulated evapotranspiration in these valleys is about 91,000 acre-ft/yr, which is considerably less than the estimated discharge of at least 126,000 acre-ft/yr (Mower, 1978, p. 30; Bjorklund and others, 1978, p. 17, 41). Estimated discharge in these valleys includes water recharged locally from streams crossing the valley floor. This local recharge is not simulated in the model, which accounts for at least part of the difference between simulated and estimated discharge in the valleys.

Simulated underflow from Beaver, Parowan, and Cedar Valleys westward to the southeastern part of the Milford area and the eastern part of the Escalante Desert is about 12,000 acre-ft/yr. In contrast, less than $1,000 \mathrm{acre}-\mathrm{ft} / \mathrm{yr}$ is estimated as underflow to the Milford area and the Escalante Desert (Mower, 1978, p. 33; Bjorklund and others, 1978, p. 45). Estimated transmissivities in this area are generally in the range of 0.0006 to $0.006 \mathrm{ft}^{2} / \mathrm{s}$ in the lower model layer (fig. $20 B$ ) and 0.006 to $0.18 \mathrm{ft}^{2} / \mathrm{s}$ in the upper layer (fig. $20 \mathrm{~A}$ ). Decreasing transmissivities in the upper layer immediately west of Beaver, Parowan, and Cedar City Valleys would increase evapotranspiration in the two valleys and decrease flow to the southern Milford area and Escalante Desert. Decreasing westward flow to the Escalante Desert is reasonable because the simulated evapotranspiration of 33,000 acre-ft/yr is about 7,000 acre-ft/ yr more than the quantity estimated by Mower (1982, p. 34). Simulated flow to the Escalante 
Desert is from recharge areas in the Kolob Terrace (referred to as Pine Valley Mountains by Mower) and The Needles, and from Parowan and Cedar Valleys (fig. 33). Instead of subsurface flow from Parowan and Cedar Valleys, Mower (1982, pl. 13) assumed ground-water recharge in the mountains between the Escalante Desert and those two valleys. These mountains are relatively low in altitude and, thus, no recharge is assigned to them in the model.

The hydraulic gradient of ground water at the north end of the Escalante Desert indicates northward flow from the Escalante Desert to the southern end of the Milford area. The estimated

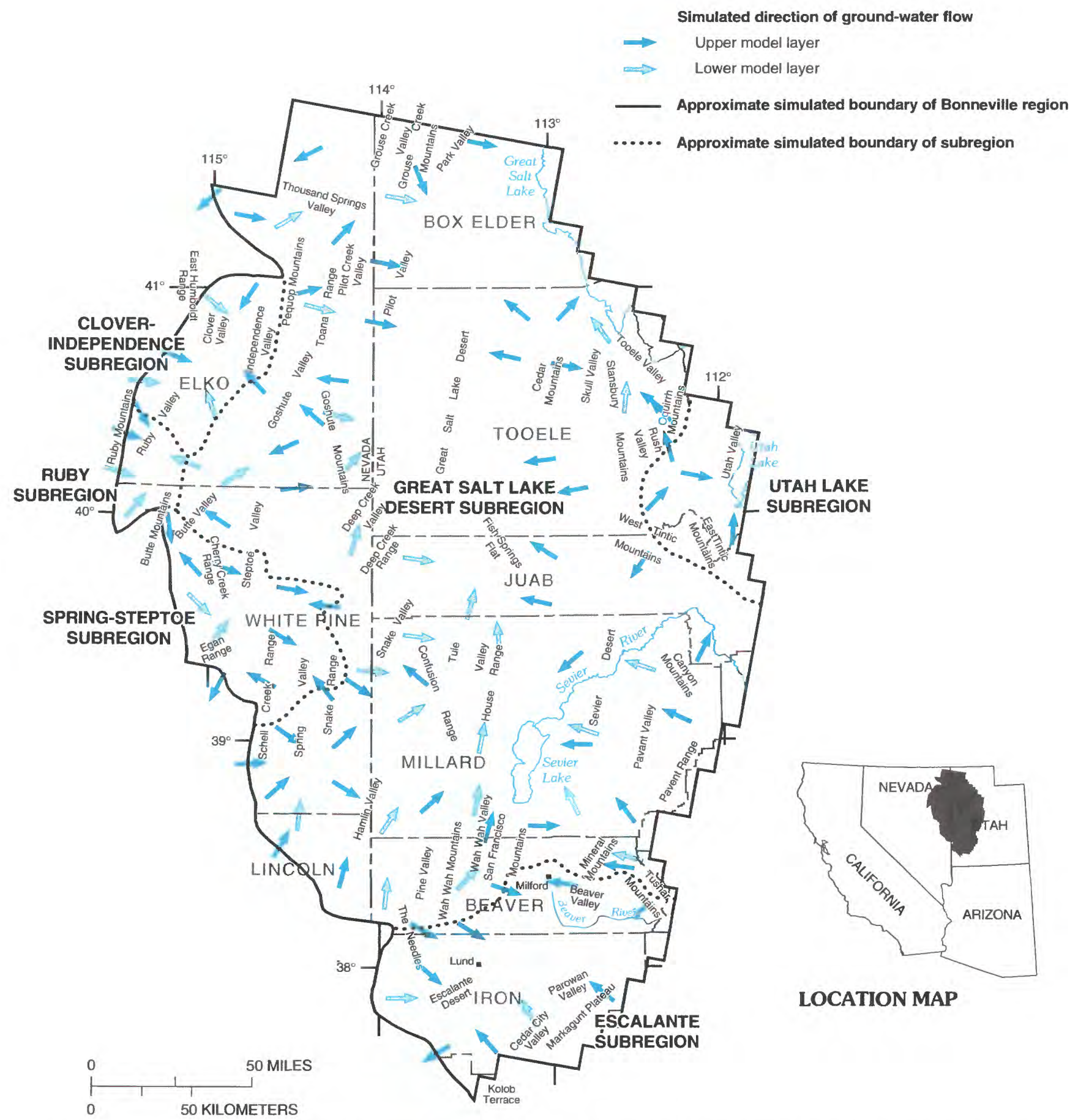

Figure 33.-Simulated direction of ground-water flow for both upper and lower model layers in Bonneville region. 
quantity of flow is about 2,100 acre-ft/yr (Mower, 1982 , p. 35). Subsurface flow simulated in the model from the Escalante Desert to southern Milford area is about 2,400 acre-ft/yr, two-thirds of which is in the upper layer.

The Milford area is split between the Escalante and the Great Salt Lake Desert subregions (fig. 32). Simulated evapotranspiration for all of the Milford area is 32,000 acre-ft/yr of which about 15,000 acre-ft/yr is simulated in the Escalante subregion. Estimates of ground-water discharge in the entire Milford area prior to development range from 27,000 acre-ft/yr (Mason, in press) to 33,000 acre-ft/yr (Mower and Cordova, 1974, p. 22). Subsurface flow from the Milford area to the Sevier Desert has been postulated by these authors on the basis of water-level gradients between the basins. In the model, all flow in the southern part of the Milford area is discharged there as evapotranspiration, rather than moving northward. Simulated flow to the northern part of the Milford area is from recharge in the San Francisco Mountains to the west and the Mineral Mountains to the east (fig. 33).

The simulated subregion boundary that splits the Milford area may be an artifact of the relatively large size of model cells. The principal direction of ground-water flow simulated in the Milford area is from east to west. With the large size of model cells, ground-water flow simulated in the lower layer is upward beneath the valley to the upper layer, where most of it is discharged as evapotranspiration.

\section{SPRING-STEPTOE SUBREGION}

The Spring-Steptoe subregion, on the west side of the Bonneville region (fig. 32), encompasses an area of $2,100 \mathrm{mi}^{2}$. It includes the northern half of Spring Valley, the southern half of Steptoe Valley, and part of southern Butte Valley. Superimposed on the deep-flow subregion are parts or all of five shallow-flow regions in the upper layer (fig. 23). The subregion boundary differs from those delineated by Harrill and others (1988) in that they include the southern two-thirds of Butte Valley and all of Steptoe Valley as one flow system and Spring Valley as part of a large system tributary to the Great Salt Lake Desert. Altitudes of the mountains and valleys in the subregion are generally higher than those in the surrounding subregions. Consequently, ground-water levels in the subregion also are generally higher (fig. 24B).
Simulated inflow to the subregion totals 101,000 acre-ft/yr (table 6), of which 93,000 acre$\mathrm{ft} / \mathrm{yr}$ is recharge assigned to model cells in the upper model layer. Principal recharge areas include the Snake, Schell Creek, Egan, and Cherry Creek Ranges (fig. 32). Subsurface inflow totals 8,000 acre- $\mathrm{ft} / \mathrm{yr}$-about $4,000 \mathrm{acre}-\mathrm{ft} / \mathrm{yr}$ is simulated from the Railroad Valley region and 4,000 acre-ft/yr from the Great Salt Lake Desert subregion, primarily in the upper layer (table 6). Outflow from the subregion is primarily from evapotranspiration, which totals about 91,000 acre$\mathrm{ft} / \mathrm{yr}$ (table 6). Simulated regional-spring discharge at Campbell Ranch Spring (fig. 11) in southern Steptoe Valley is 7,400 acre-ft/yr (table 1, fig. 32). Subsurface flow to the Colorado River region is 3,000 acre-ft/yr and accounts for the rest of the simulated outflow.

Estimated transmissivities for the lower layer in the Spring-Steptoe subregion are generally less than $0.006 \mathrm{ft}^{2} / \mathrm{s}$; as a result, most of the simulated flow is in the upper layer. About 82 percent of the total inflow to the subregion is simulated through the upper layer. Flow from the upper layer into the lower layer is about 17,000 acre-ft/yr. Nearly half (44 percent) of the downward flow from the upper layer is discharged from the lower layer at Campbell Ranch Spring in southern Steptoe Valley (table 1, fig. 32).

A topographic divide of low relief in the central part of Spring Valley corresponds to the approximate subregion boundary between the Spring-Steptoe and Great Salt Lake Desert subregions. In northern Spring Valley, simulated flow is eastward from the Schell Creek Range and westward from the Snake Range (fig. 33) to the valley floor. Flow is simulated mostly in the upper model layer. Low-permeability rocks are widely exposed in these mountains, and the rocks may extend to great depth, as inferred from subsurface magnetic bodies (fig. 24). In southern Spring Valley, ground-water flow is simulated through the Snake Range into Hamlin Valley (fig. 33). An estimated 4,000 acre-ft/yr of subsurface flow is thought to move from Spring Valley into Hamlin Valley through the Snake Range (Rush and Kazmi, 1965 , p. 19). This estimate is based on a hydraulic gradient in basin fill in southern Spring Valley that is toward the Snake Range. Simulated discharge in Spring Valley is 75,000 acre-ft/yr (fig. 32 ), of which 39,000 acre- $\mathrm{ft} / \mathrm{yr}$ is in the SpringSteptoe subregion. Estimated discharge by evapotranspiration for the entire valley is 70,000 acre-ft/yr (Rush and Kazmi, 1965, p. 22). The es- 
timate includes the discharge of numerous small, nonregional springs and seeps near the margin of the valley floor.

In southern Steptoe Valley, simulated flow is westward from the Schell Creek Range and eastward from the Egan and Cherry Creek Ranges (fig. 33). Simulated evapotranspiration and regional-spring discharge for the entire valley totals 75,000 acre-ft/yr. In comparison, estimated evapotranspiration in the valley, which includes the discharge from regional springs, is 70,000 acre$\mathrm{ft} / \mathrm{yr}$ (Eakin and others, 1967, p. 24). Simulated evapotranspiration and regional spring discharge in the southern part of Steptoe Valley (within the Spring-Steptoe subregion) is 45,000 acre-ft/yr.

The simulated subregion boundary that splits Steptoe Valley between two deep-flow subregions does not correspond to either a topographic divide of low relief or a water table divide in the basin fill. The boundary may be an artifact of the relatively large size of the model cells. The principal directions of simulated flow in both layers are east and west from the adjacent mountains to areas of evapotranspiration on the valley floors. Reducing the size of model cells might allow for a small northward component of flow through the valley that is not simulated with the larger cell size.

Simulated flow in Butte Valley is westward from the Egan and Cherry Creek Ranges and eastward from Butte Mountains (fig. 33). Simulated evapotranspiration is $20,000 \mathrm{acre}-\mathrm{ft} / \mathrm{yr}$, the same as that estimated by Glancy (1968a, p. 32). Within the Spring-Steptoe subregion, simulated evapotranspiration in the southern part of Butte Valley is 7,000 acre-ft/yr. A ground-water divide in the basin fill is present near a topographic divide that separates the northern one-third of the valley from the southern two-thirds (Glancy, 1968a, p. 11). In the model, the divide between deepflow subregions is south of the actual ground-water divide, but a shallow-flow region divide in the upper layer approximates the observed divide.

Depth to ground water beneath the playa at the southern end of Butte Valley exceeds $50 \mathrm{ft}$. The reason for the depressed water table is unknown; phreatophytes in the central part of the valley may consume enough ground water to keep the water table depressed, or the ground water in southern Butte Valley may flow generally southward through underlying carbonate rocks to discharge areas in adjacent valleys (Glancy, 1968a, p. 11). Although Butte Valley could be a source area for water discharging at Campbell Ranch
Spring on the east side of the Egan Range (fig. 32), shallow ground-water flow is considered doubtful because of a low hydraulic gradient between Butte Valley and the springs and because a ground-water mound from recharge in the Egan Range would be a barrier to shallow flow between the two valleys (Eakin and others, 1967, p. 21).

Deeper ground-water flow from Butte Valley to Steptoe Valley beneath the Egan Range may be possible. The rocks are largely carbonates and may extend to great depth. In the model, a groundwater mound is simulated beneath the Egan Range, yet outflow in the lower layer is simulated as deep flow from the southern end of Butte Valley to Campbell Ranch Spring. In this area, transmissivities computed in the lower layer correspond to a zone of relatively high values (greater than $0.006 \mathrm{ft}^{2} / \mathrm{s}$ ) that extends to the southern end of the study area (fig. 25). The quantity of subsurface flow simulated in the lower layer from southern Butte Valley to Campbell Ranch Spring is 2,100 acre-ft/yr. The remaining 5,300 acre- $\mathrm{ft} / \mathrm{yr}$ of simulated flow to the spring is from nearby, in the Egan Range.

Geochemical evidence seems to support the concept of both long and short flow paths to Campbell Ranch Spring. Detectable concentrations of tritium in the spring water indicates that some of the water discharging at the spring is from recent (post-1952) precipitation (James M. Thomas, U.S. Geological Survey, oral commun., 1986), perhaps from the Egan Range. In contrast, the carbon-14 content of the spring water (17 percent of modern carbon) indicates that some of the water may be several thousand years old, a reasonable travel time for water from Butte Valley.

Whether ground water actually flows from southern Butte Valley to Campbell Ranch Spring is uncertain. Discharge simulated at the spring is sensitive to relatively small transmissivity changes in the lower layer. For example, increasing transmissivities of model cells in White River Valley results in decreased flow to Campbell Ranch Spring because more water is diverted into White River Valley.

\section{RUBY SUBREGION}

The Ruby subregion, in the western part of the Bonneville region (fig. 32), encompasses only $550 \mathrm{mi}^{2}$ - the smallest of the six deep-flow subregions. It includes the southern two-thirds of a shallow flow region (fig. 23). The extent of the subregion differs from a flow system delineated 
by Harrill and others (1988) in that their system includes all of Ruby Valley and the northern third of Butte Valley. Simulated ground-water flow in the Ruby subregion is from the adjacent Ruby and Butte Mountains to the floor of southern Ruby Valley (fig. 33).

Simulated inflow to the subregion totals 34,000 acre-ft/yr, of which only 14,000 acre-ft/yr is from recharge assigned to cells in the upper model layer (table 6) -the rest is subsurface flow from adjacent subregions and regions. Most of the subsurface flow into the subregion is from the upper Humboldt River region, where simulated inflow along the Ruby Mountains is 16,000 acre-ft/yr $(11,000 \mathrm{acre}-\mathrm{ft} / \mathrm{yr}$ of which is in the upper layer). Inflow from the upper Humboldt River region is the result of model discretization. Cells along the crest of the Ruby Mountains (where simulated flow is both east and west) had to be included in either the Ruby subregion or the upper Humboldt River region. Cells along the crest are assigned to the upper Humboldt River region; thus, in the simulated water budgets, flow eastward from the crest is accounted for as subsurface outflow from the upper Humboldt River region to the adjacent Ruby subregion.

Simulated outflow from the Ruby subregion is 34,000 acre-ft/yr, of which 32,000 acre-ft/yr is evapotranspiration from the upper model layer and 2,000 acre-ft/yr is subsurface flow to the Railroad Valley region, primarily in the lower layer (table 6). In comparison, estimated evapotranspiration in the southern half of Ruby Valley, which approximately coincides with the Ruby subregion, is about 30,000 acre-ft/yr (Eakin and others, 1951, p. 82).

Within the Ruby subregion, transmissivities in the upper layer mostly range from 0.18 to 0.66 $\mathrm{ft}^{2} / \mathrm{s}$ beneath the valley floor, but are less than $0.006 \mathrm{ft}^{2} / \mathrm{s}$ in the Ruby Mountains (fig. 20A). Values in the lower layer follow a similar trendhigher beneath the valley floor than beneath the mountain block (fig. 20B).

The Ruby Mountains constitutes one of the highest ranges in northeast Nevada and, consequently, receives more precipitation, on the average, than all other nearby ranges. In the northern Ruby Mountains, where metamorphic and igneous rocks of low permeability are exposed (fig. 24A; Plume and Carlton, 1988, pl. 1), numerous streams flow from the mountains to the neighboring valley floors, because little precipitation percolates into the rocks. Contrastingly, in the southern Ruby Mountains, where carbonate rocks are exposed, few streams are present because most of the precipitation percolates into these more permeable rocks. Considerable ground water flows locally through the carbonate rocks to the neighboring valleys. For example, Ruby Lake, at the southern end of the Ruby Valley, is fed by springs and seeps discharging from carbonate rocks at the base of the mountains.

The simulated division of Ruby Valley into two separate subregions may be a result of the large size of the model-grid cells. Available groundwater levels in the basin fill do not indicate a divide in Ruby Valley (Thomas and others, 1986, pl. 1), although a topographic divide of low relief separates Ruby Lake from the northern part of the valley. The principal directions of simulated ground-water flow in the model are eastward from the Ruby Mountains and westward from the Butte Mountains (fig. 33) to areas of evapotranspiration on the valley floor. These flow directions are accentuated in the model by the rectangular grid.

\section{CLOVER-INDEPENDENCE SUBREGION}

The Clover-Independence subregion, north of the Ruby subregion on the west side of the Bonneville region (fig. 32), encompasses about $1,400 \mathrm{mi}^{2}$. The subregion incorporates all or part of three shallow-flow regions in the upper layer. The subregion includes Clover and Independence Valleys and the northern parts of Butte and Ruby Valleys. This subregion is slightly different from the flow system delineated by Harrill and others (1988), as they do not include northern Butte and Ruby Valleys.

Simulated inflow to the subregion is 44,000 acre-ft/yr, of which recharge assigned to model cells in the upper model layer totals 33,000 acre$\mathrm{ft} / \mathrm{yr}$ (table 6). Principal recharge areas include the Ruby Mountains, East Humboldt Range, and Pequop Mountains (fig. 32). Subsurface inflow from the upper Humboldt River region, simulated through the lower layer along the Ruby Mountains, is about 9,000 acre-ft/yr. An additional 2,000 acre- $\mathrm{ft} / \mathrm{yr}$ is simulated as subsurface inflow through the upper layer from the Great Salt Lake Desert subregion.

Simulated evapotranspiration in the subregion is 36,000 acre-ft/yr (table 6), including 10,000 acre$\mathrm{ft} / \mathrm{yr}$ in northern Ruby Valley, 2,000 acre-ft/yr at the north end of Butte Valley, and 24,000 acre$\mathrm{ft} / \mathrm{yr}$ in Clover and Independence Valleys (fig. 32). Regional-spring discharge simulated from the lower layer in southern Clover Valley is 5,000 acre- 
$\mathrm{ft} / \mathrm{yr}$, at Warm Springs (table 1; figs. 11, 32). An additional 3,000 acre- $\mathrm{ft} / \mathrm{yr}$ is simulated as subsurface outflow to the Ruby subregion, about half through the lower layer.

Ground-water flow is generally from recharge areas in the mountains to discharge areas on the valley floors (fig. 33). About 71 percent of the total inflow to the subregion is simulated through the upper layer. In the lower layer, simulated flow to Warm Springs is from the Ruby Mountains and East Humboldt Range (fig. 33).

Estimated evapotranspiration in Clover and Independence Valleys is about 29,000 acre-ft/yr (Eakin and others, 1951, p. 110, 112), which is the same quantity simulated in the model when discharge from Warm Springs is included. However, estimated evapotranspiration in northern Ruby Valley-about 38,000 acre-ft/yr (Eakin and others, 1951, p. 82) -is 28,000 acre-ft/yr more than the simulated quantity. Increasing the simulated evapotranspiration in northern Ruby Valley by reducing subsurface flow to Clover and Independence Valleys would result in a similar decrease in simulated evapotranspiration in the latter valleys. One alternative would be to adjust transmissivities in the Clover-Independence subregion until more flow is from recharge areas to the east and south. However, simulated flow from northern Ruby Valley is not enough to account for the 28,000-acre-ft/yr discrepancy. The only logical area where more flow can be simulated to northern Ruby Valley is in the Ruby Mountains, either by increasing recharge in model cells corresponding to the mountain block or by adjusting transmissivities in the area to divert more recharge from the Ruby Mountains into northern Ruby Valley. Perhaps some of the estimated evapotranspiration is related to surface water. Many streams flow from the east flank of the northern Ruby Mountains onto the adjacent valley floor. These streams are used for irrigation of meadow lands, but some streamflow probably seeps into the ground, where it is then discharged locally as evapotranspiration. Local flow of this type is not simulated in the model, because recharge and discharge is not simulated in the same model cell.

\section{UTAH LAKE SUBREGION}

The Utah Lake subregion, in the northeast corner of the Bonneville region (fig. 32), encompasses $1,400 \mathrm{mi}^{2}$. The southern boundary of the subregion generally corresponds to a flow-system boundary by Harrill and others (1988) that sepa- rates ground-water flow to the Sevier Desert from flow to the Great Salt Lake. Elsewhere, the subregion does not correspond to their flow system because they consider Utah Lake a part of a larger flow system that includes all tributary valleys surrounding the Great Salt Lake. Some ground water flows northward from Utah Lake toward the Great Salt Lake; however, this was not simulated in the conceptual model because both lakes are treated separately.

Utah Lake, in Utah Valley, lies at the base of the Wasatch Range, which is east of the lake and outside of the modeled area. Streams that head in the Wasatch Range are the major source for irrigation water and one of the major sources of recharge to ground water in Utah Valley (Cordova and Subitzky, 1965, p. 12; Cordova, 1970, p. 23). Because only areas west of Utah Valley are simulated in the model, much of the estimated ground-water recharge to the valley is not included therein. Estimated ground-water discharge from the northern part of Utah Valley exceeds 200,000 acre-ft/yr (Cordova and Subitzky, 1965, p. 19), and discharge from southern Utah Valley exceeds 125,000 acre-ft/yr (Cordova, 1970, p. 30). Both estimates do not include discharge from wells. Only a small part of the estimated discharge in Utah Valley is subsurface flow from areas west of Utah Lake. Simulated discharge to Utah Valley in the model includes only the ground-water flow from areas west of Utah Valley. Estimates of underflow from west of Utah Valley range from 10,000 acre-ft/yr (Feltis, 1967, p. 18) to 24,000 acre-ft/yr (Harrill and others, 1988).

Simulated inflow to the Utah Lake subregion is 53,000 acre-ft/yr, all of which is recharge assigned to cells in the upper model layer (table 6). Principal recharge areas are the Oquirrh Mountains and the East and West Tintic Mountains (fig. 32). Simulated outflow from the subregion includes 18,000 acre- $\mathrm{ft} / \mathrm{yr}$ as evapotranspiration from the upper layer, 22,000 acre-ft/yr as flow to Utah Lake, and 13,000 acre-ft/yr as subsurface flow, primarily through the upper layer, to Tooele Valley in the Great Salt Lake Desert subregion. In Utah Valley, total simulated discharge is 33,000 acre-ft/yr (fig. 32), which includes 11,000 acre-ft/yr of evapotranspiration.

Flow in both model layers is generally from recharge areas to Utah Lake (fig. 33). About 87 percent of the total inflow to the subregion is simulated through the upper layer. Simulated underflow to Utah Valley from areas to the west is more than the estimated underflow of 24,000 acre-ft/yr (Harrill 
and others, 1988). Because the model boundary north of the lake is along the northern Oquirrh Mountains, some of the simulated underflow to the valley may actually move east from the mountains to the Jordan River (Waddell and others, 1987, p. 7). In the model, ground-water flow from the Oquirrh Mountains is to Utah Lake, Rush Valley, and Tooele Valley (fig. 33).

\section{GREAT SALT LAKE DESERT SUBREGION}

The Great Salt Lake Desert subregion extends over much of western Utah and extreme eastern Nevada (fig. 32) and has an area of about 29,500 $\mathrm{mi}^{2}$. It is the largest subregion delineated in the entire study area. The subregion includes all or most of 13 shallow-flow regions (fig. 23). The subregion differs from the flow system delineated by Harrill and others (1988) in that it includes the Sevier Desert and valleys adjacent to the Great Salt Lake in Utah, and Goshute and northern Steptoe Valleys in eastern Nevada (fig. 32). Although the Great Salt Lake Desert and the Great Salt Lake are delineated by Harrill and others (1988) as separate flow systems, the topographically lowest discharge areas in the two flow systems constitute one virtually continuous area that can be considered a single large system (Gates, 1987 , p. 83). Sparse water-level data suggest that some ground water may flow from the Sevier Desert and Goshute Valley to discharge areas in the Great Salt Lake Desert (Gates, 1987, p. 84; Harrill and others, 1988), implying that these areas also could be included with the Great Salt Lake Desert as part of a single flow system.

Inflow to the subregion is 542,000 acre-ft/yr, of which 524,000 acre-ft/yr is from recharge assigned to cells in the upper model layer. Principal mountain ranges, where recharge exceeds 30,000 acre-ft/yr apiece, are the Pavant Range, Oquirrh Mountains, Stansbury Mountains, and Deep Creek Range in Utah, and the southern Schell Creek and Snake Ranges in Nevada (fig. 32). Simulated inflow from adjacent regions and subregions, primarily through the upper layer, includes 13,000 acre-ft/yr from the Utah Lake subregion and 5,000 acre-ft/yr from the Colorado River region (table 6). Underflow from the Utah Lake subregion is in the vicinity of Oquirrh Mountains and Rush Valley, whereas underflow from the Colorado River region is near Hamlin Valley (fig. 33).

Simulated outflow from the subregion includes: 442,000 acre-ft/yr as evapotranspiration from the upper model layer; 37,000 acre-ft/yr as leakage through head-dependent flow boundaries to the Great Salt Lake, the Sevier River, and Sevier Lake in the upper layer; 52,000 acre-ft/yr as regionalspring discharge from the lower layer; and 11,000 acre-ft/yr as subsurface flow to adjacent subregions and to the upper Humboldt River region (table 6). Principal areas of ground-water discharge include: Rush, Skull, and Tooele Valleys at the south end of the Great Salt Lake; the Sevier River drainage, Pavant Valley, and northern Milford area in the southeastern part of the subregion; the Great Salt Lake Desert, Tule Valley, and Snake Valley in western Utah; and the south end of Spring Valley, the north end of Steptoe Valley, and all of Goshute Valley in eastern Nevada (fig. 32). Regionalspring discharge is from two areas on the margin of the Great Salt Lake Desert-Fish Springs and Blue Lake and Little Salt Springs-and from Twin Spring in Snake Valley, and Nelson Spring in northern Steptoe Valley (figs. 11, 32; table 1).

Simulated flow in the subregion is primarily in the upper layer from recharge areas in the mountains to discharge areas on the adjacent valley floors. About 78 percent of the total inflow is simulated through the upper layer. Flow entering the lower layer from the upper layer is about 115,000 acre-ft/yr. Much of the flow in the lower layer is concentrated in three general areas where estimated transmissivities exceed $0.006 \mathrm{ft}^{2} / \mathrm{s}$ : a relatively small area at the south end of the Great Salt Lake, extending to Rush Valley; a relatively long and narrow area extending from the south end of the Great Salt Lake Desert to Wah Wah Valley; and a relatively small and narrow area extending southwestward from Blue Lake and Little Salt Springs in extreme western Utah (fig. 25). Of the simulated flow entering the lower layer from the upper layer, 45 percent is discharged at regional springs.

Most of the simulated flow toward Great Salt Lake is discharged before reaching it. Simulated leakage to Great Salt Lake is only about 3,000 acre-ft/yr. Much of this (about 2,700 acre-ft/yr) is at the north end of Tooele Valley. The remaining 300 acre-ft/yr is simulated along the shore of the Great Salt Lake north of Skull Valley (fig. 32). Estimated ground-water leakage to the Great Salt Lake from Tooele Valley is 3,000 acre-ft/yr (Razem and Steiger, 1981, p. 17). The area along the Great Salt Lake northwest of Tooele Valley discharges little, if any, ground water directly to the lake (Arnow, 1984, p. 16).

Simulated flow at the south end of the Great Salt Lake is primarily from recharge areas in the 
Oquirrh, West Tintic, Stansbury, and Cedar Mountains to areas of discharge in Rush, Tooele, and Skull Valleys (fig. 33). Simulated discharge in these valleys is 99,000 acre-ft/yr (fig. 32 ), which is within the range estimated by previous investigators. The estimates range from 94,000 acre$\mathrm{ft} / \mathrm{yr}$ to 113,000 acre-ft/yr, as follows: Rush Valley, 27,000 acre-ft/yr (Hood and others, 1969, p. 28); Tooele Valley, 23,000 as evapotranspiration and 17,000 as spring discharge (Razem and Steiger, 1981, p. 16); and Skull Valley, 27,000 to 46,000 acre-ft/yr (Hood and Waddell, 1968, p. 29). About 16,000 acre-ft/yr is simulated as ground-water flow from Rush Valley into Tooele Valley, of which 6,000 acre- $\mathrm{ft} / \mathrm{yr}$ is by way of the lower layer.

Simulated flow in the Sevier Desert area is generally toward the Sevier River and Sevier Lake (fig. 33). About 89 percent of the total inflow to this area is through the upper layer, because estimated transmissivities in the lower layer are less than $0.006 \mathrm{ft}^{2} / \mathrm{s}$ (fig. 20B). Simulated discharge as evapotranspiration from Sevier Desert and as leakage to the Sevier River and Sevier Lake is 44,000 acre- $\mathrm{ft} / \mathrm{yr}$, which is considerably less than estimated by previous investigators. Estimated ground-water discharge, excluding subsurface outflow, in the Sevier Desert ranges from 83,000 acre$\mathrm{ft} / \mathrm{yr}$ (Holmes, 1984, p. 27) to 175,000 acre-ft/yr (Mower and Feltis, 1968, p. 52). Some of the difference between the quantity of discharge simulated herein and that reported by Holmes (1984, p. 27) is due to an additional 24,000 acre- $\mathrm{ft} / \mathrm{yr}$ of recharge he estimated as seepage from canals, reservoirs, and unconsumed irrigation water. Recharge from irrigation water is not included in the model because it is assumed to be local flow and because only a net recharge or discharge is simulated for each cell. Another reason for the difference is that Holmes (1984, p. 27) simulated about 27,000 acre-ft/yr of underflow from Pavant Valley to the Sevier Desert. This value is considerably higher than the 3,400 acre-ft/yr simulated herein and the 14,000 acre-ft/yr estimated by Mower (1965, p. 54).

Evapotranspiration is simulated over a large area of the Great Salt Lake Desert (fig. 32); however, the total is about 14,000 acre- $\mathrm{ft} / \mathrm{yr}$. More evapotranspiration actually occurs in this area than is simulated in the model, but much of the additional discharge is derived from local precipitation on the desert floor. Estimated evapotranspiration from the Great Salt Lake Desert is 84,000 acre-ft/yr. It includes about 69,000 acre-ft/yr of local evaporation from mud and salt flats (Gates,
1984, p. 244). If this local discharge is not included, the model-simulated quantity is about the same as the estimated quantity. The combination of only small quantities of ground-water discharge and low hydraulic gradients results in transmissivities that are generally very low-less than $0.0006 \mathrm{ft}^{2} / \mathrm{s}$ (fig. 20). Whether these values are representative of the actual transmissivities is uncertain because the model results in this area are insensitive to changes in assigned transmissivities in either model layer and vertical leakances between the layers.

Simulated flow in the southwestern part of the subregion is generally toward a band of high transmissivities (between 0.18 and $0.66 \mathrm{ft}^{2} / \mathrm{s}$; fig. 20 ) estimated in both layers that extends from Wah Wah Valley to Fish Springs Flat at the south end of the Great Salt Lake Desert (fig. 33). The band of high transmissivities correlates to a zone of relatively thick, flat-lying carbonate rocks that acts as a major conduit for ground-water flow (Carlton, 1985, p. 53).

Simulated outflow as evapotranspiration and as regional-spring discharge in the southwestern part of the subregion totals 144,000 acre-ft/yr, exclusive of southern Spring Valley. Simulated evapotranspiration includes 36,000 acre-ft/yr in southern Spring Valley; 12,000 acre-ft/yr in Hamlin Valley; 5,000 acre-ft/yr in Pine Valley; 56,000 acre$\mathrm{ft} / \mathrm{yr}$ in Snake Valley; 32,000 acre-ft/yr in Tule Valley; and 9,000 acre-ft/yr in Fish Springs Flat (fig. 32). Simulated regional-spring discharge from the lower layer totals 30,000 acre-ft/yr: 4,000 acre$\mathrm{ft} / \mathrm{yr}$ from Twin Spring in Snake Valley and 26,000 acre-ft/yr from Fish Springs (fig. 32).

The simulated outflow in this part of the subregion, exclusive of southern Spring Valley, is about 12,000 to 20,000 acre-ft/yr less than the estimated discharge of 156,000 to 164,000 acre$\mathrm{ft} / \mathrm{yr}$. Estimated discharge by valley is as follows: Snake and Hamlin Valleys, 80,000 acre-ft/yr (Hood and Rush, 1965, p. 24, 25); Pine Valley, 7,000 acre-ft/yr (Stephens, 1976, p. 17); Tule Valley, 32,000 to $40,000 \mathrm{acre}-\mathrm{ft} / \mathrm{yr}$. (Stephens, 1977, p. 19; Gates and Kruer, 1981, p. 36); Wah Wah Valley, 1,500 acre-ft/yr (Stephens, 1974b, p. 27); and Fish Springs Flat, about 35,000 acre$\mathrm{ft} / \mathrm{yr}$, including the flow from Fish Springs (Bolke and Sumsion, 1978, p. 13). Most of the difference between simulated and estimated discharge is in Snake, Hamlin, and Tule Valleys, where the simulated quantity is 12,000 to 20,000 acre-ft/yr less than the estimated quantity. Perhaps a larger area than that simulated contributes 
flow to this part of the Great Salt Lake subregion.

As with many of the relatively large springs in the study area, discharge at Fish Springs greatly exceeds the quantity of recharge estimated for the topographic drainage area. Estimated recharge in Fish Springs Flat is only 4,000 acre-ft/yr (Bolke and Sumsion, 1978, p. 9), suggesting that most of the spring flow is from adjoining basins. Evidence for interbasin flow to Fish Springs Flat is based on the presence of carbonate rocks that crop out in several mountain ranges to the south; the imbalance in water budgets (Gates and Kruer, 1981, p. 31), where recharge exceeds discharge in Snake, Pine, and Wah Wah Valleys; and the indication from water-level data that ground-water flow is eastward from Snake Valley, northward from Pine and Wah Wah Valleys, and perhaps westward from Sevier Desert toward Fish Springs (Gates, 1987, p. 85).

Simulated flow entering Fish Springs Flat from adjacent areas differs between model layers. Simulated flow in the upper layer is primarily from the east and southeast, whereas simulated flow in the lower layer is primarily from the south and west (fig. 33). Total inflow to the upper model layer is about 10,300 acre- $\mathrm{ft} / \mathrm{yr}$, including 1,700 acre-ft/yr as recharge from mountain ranges, 4,200 acre-ft/yr as underflow from areas to the east, 1,600 acre-ft/yr as northward flow from Tule Valley, 900 acre-ft/yr as northwestward flow from Sevier Desert, 300 acre$\mathrm{ft} / \mathrm{yr}$ as eastward flow from Snake Valley, and 1,600 acre-ft/yr as upward flow from the lower layer. Total outflow equals inflow and includes 8,700 acre-ft/yr as evapotranspiration and 1,600 acre$\mathrm{ft} / \mathrm{yr}$ as northward flow to the Great Salt Lake Desert. Total inflow to the lower layer is about 27,200 acre-ft/yr, including 19,700 acre-ft/yr as northward flow from Tule Valley, 6,500 acre-ft/yr as eastward flow from Snake Valley, and a combined 1,000 acre-ft/yr as westward and northwestward flow from areas to the east and Sevier Desert. Total outflow equals inflow and includes 25,700 acre-ft/yr as regional flow at Fish Springs and 1,600 acre-ft/yr as leakage to the upper layer. Eastward flow in the lower layer from Snake Valley to Fish Springs is mostly from recharge in the Deep Creek Range (fig. 33)-a source area suggested by Gates and Kruer (1981, p. 32).

At least half of the simulated flow to Fish Springs Flat from Tule Valley originates in the Snake Valley drainage basin. Of the 23,000 acre$\mathrm{ft} / \mathrm{yr}$ simulated as entering Tule Valley in the lower layer, 14,000 is underflow from Snake Valley through the Confusion Range and 9,000 is from Wah Wah Valley.

Available water-level data suggest that subsurface flow from Sevier Desert to Tule Valley and, thence, Fish Springs Flat is likely (Gates, 1987 , p. 85). Not counting northward flow from Wah Wah Valley through the extreme western side of Sevier Desert, about 1,200 acre-ft/yr is simulated as subsurface flow from Sevier Desert to Tule Valley and, thence, Fish Springs Flat. Combining the 1,200 acre-ft/yr with the 1,600 acre$\mathrm{ft} / \mathrm{yr}$ simulated as direct underflow from Sevier Desert to Fish Springs Flat results in 2,800 acre$\mathrm{ft} / \mathrm{yr}$ as underflow from Sevier Desert to adjoining areas along the westside. This quantity is less than the 8,800 acre-ft/yr simulated by Holmes (1984, p. 27). Although the quantity of flow from Sevier Desert to Tule Valley and Fish Springs Flat is different in the conceptual model than that determined by Holmes, both values are considered approximate because the hydraulic properties of rocks west of the Sevier Desert are largely unknown.

Ground-water levels along the west and north sides of the subregion generally decrease toward the Great Salt Lake Desert (figs. 19, 23, and 24). Simulated flow in this part of the subregion is primarily through the upper layer from recharge areas in the mountains to discharge areas in adjacent valley floors. In general, simulated evapotranspiration in valleys west and north of the Great Salt Lake Desert (fig. 32) approximates estimated values. Estimates of discharge are as follows: Goshute Valley, 10,000 acre-ft/yr (Eakin and others, 1951, p. 28); Deep Creek Valley, 14,000 to 17,000 acre-ft/yr (Hood and Waddell, 1969, p. 25; Gates and Kruer, 1981, p. 26, 36); Pilot Creek Valley, 4,600 acre-ft/yr (Harrill, 1971, p. 29); Thousand Springs Valley, 5,700 acre-ft/yr (Rush, 1968c, p. 35); Pilot, Grouse Creek, and Park Valleys, $7,400,11,000$, and 16,000 acre-ft/yr, respectively (Stephens, 1974a, p. 30). A small quantity of ground-water flow (less than 2,000 acre-ft/yr) is simulated between several hydrographic basins. For example, about 1,700 acre-ft/yr is simulated from Goshute Valley to Pilot Creek Valley. This is slightly more than the 1,000 acre-ft/yr estimated by Harrill (1971, p. 28).

More than half of the flow simulated in the lower layer on the west side of the Great Salt Lake Desert is discharged at Blue Lake and Little Salt Springs (fig. 32). Ground-water flow to these springs, as simulated in the model, is mostly from 
the Deep Creek Range to the south and the Goshute Mountains to the west (fig. 33). During model calibration, transmissivities were increased south and west of the springs to increase spring discharge and to decrease discharge by evapotranspiration in valleys between the springs and Spring Valley. Perhaps other combinations of transmissivities in and upgradient from the spring area could just as reasonably simulate discharge at the springs and in the adjacent valleys. The actual quantity of flow from the Deep Creek Range to Blue Lake and Little Salt Springs may be less than the simulated quantity, because simulated discharge in Deep Creek Valley (fig. 32) is less than the estimated discharge.

\section{RAILROAD VALLEY REGION}

The Railroad Valley region, in the west-central part of the study area (fig. 24), encompasses about $7,200 \mathrm{mi}^{2}$. It contains no deep-flow subregions in the lower model layer (fig. 34) but includes all or part of 10 shallow-flow regions in the upper layer (fig. 23). The Railroad Valley region differs from the flow system delineated by Harrill and others (1988) in that it includes most of Long Valley, northern Jakes Valley, and southern Newark Valley to the north; and northern and central parts of Little Smoky Valley, most of Antelope Valley, and northern Stone Cabin Valley to the west.

Railroad Valley is the terminal discharge area for ground-water flow within the region and also is the principal area for oil production in Nevada. The oil, which is produced primarily from traps in Tertiary volcanic rocks overlying the Paleozoicage carbonate rocks (French and Freeman, 1979, p. 487), is probably derived from the Chainman Shale of Paleozoic age (Poole and Claypool, 1984, p. 201). Locally, the Chainman Shale confines ground-water flow in the underlying carbonate rock aquifers. Regionally, however, the shale may not confine ground-water flow in these aquifers because it is disrupted by numerous faults.

\section{INFLOW}

Simulated inflow to the Railroad Valley region is 134,000 acre- $\mathrm{ft} / \mathrm{yr}$, of which 132,000 acre$\mathrm{ft} / \mathrm{yr}$ is recharge assigned to cells in the upper model layer and 2,000 acre-ft/yr is subsurface flow from the Bonneville region, primarily in the up- per layer (table 7). Principal recharge areas include the Butte Mountains and White Pine Range in the northeast, the Grant and Quinn Canyon Ranges in the southeast, and the Hot Creek and Monitor Ranges in the west (fig. 34). Several other mountain ranges are also assigned small quantities of recharge.

\section{OUTFLOW}

Outflow from the Railroad Valley region is simulated as discharge by evapotranspiration in the upper model layer, as discharge from regional springs in the lower layer, and as subsurface flow to adjacent regions. Simulated discharge by evapotranspiration includes flow from small springs that is not simulated as regional-spring flow from the lower layer. Simulated outflow from the region is 133,000 acre-ft/yr, including 86,000 acre-ft/yr as evapotranspiration, $24,000 \mathrm{acre}-\mathrm{ft} / \mathrm{yr}$ as $\mathrm{re}$ gional-spring discharge, and 23,000 acre-ft/yr as subsurface flow to adjacent regions (table 7). Areas of evapotranspiration, shown in figure 34, are simulated in Railroad Valley, Hot Creek Valley, the northern part of Little Smoky Valley, and the northern part of Long Valley. Regional-spring discharge is simulated at Duckwater in northern Railroad Valley (13,000 acre-ft/yr, from Big and Little Warm Springs, table 1), on the east and west sides of Railroad Valley (6,000 acre-ft/yr, from Lockes, Blue Eagle, and Tom Springs, table 1), in Little Smoky Valley (2,800 acre-ft/yr, from Fish Creek Spring, table 1), and in Hot Creek Valley (2,000 acre-ft/yr, from Hot Creek Ranch Springs, table 1). Subsurface outflow includes: 10,000 acre$\mathrm{ft} / \mathrm{yr}$ to the upper Humboldt River region along the east side of Newark Valley and at the north end of Antelope Valley, 8,000 acre-ft/yr to the Death Valley region on the west side of the Monitor Range, 4,000 acre-ft/yr to the Bonneville region on the north end and east side of Long Valley, and 1,000 acre-ft/yr to the Colorado River region at the southern end of Jakes Valley (table 7, fig. 34).

Simulated evapotranspiration and regionalspring discharge in Railroad Valley total about 84,000 acre-ft/yr (fig. 34). This compares closely with an estimated evapotranspiration of 80,000 acre-ft/yr (Van Denburgh and Rush, 1974, p. 24), which includes evapotranspiration of flow from the regional springs. Simulated evapotranspiration and regional-spring discharge in Hot Creek Valley is about 15,000 acre-ft/yr (fig. 34). This discharge is about 10,000 acre-ft/yr more than the 
evapotranspiration from phreatophytes and from areas irrigated with spring flow estimated by Rush and Everett (1966a, p. 27). The difference in simulated to estimated discharge in Hot Creek Valley represents simulated ground-water flow from Stone Cabin and Little Fish Lake Valleys (fig. 34). No evapotranspiration is simulated in Little Fish Lake Valley, even though 10,000 acre-ft/yr is estimated for the valley (Rush and Everett, 1966a, p. 27). However, the combined quantity of simulated discharge from Hot Creek and Little Fish Lake Valleys $(15,000$ acre-ft/yr) agrees with the combined quantity of estimated discharge from the two valleys. The simulated distribution of discharge probably would agree more closely with the distribution observed by Rush and Everett (1966a, pl. 1) if

\section{EXPLANATION}

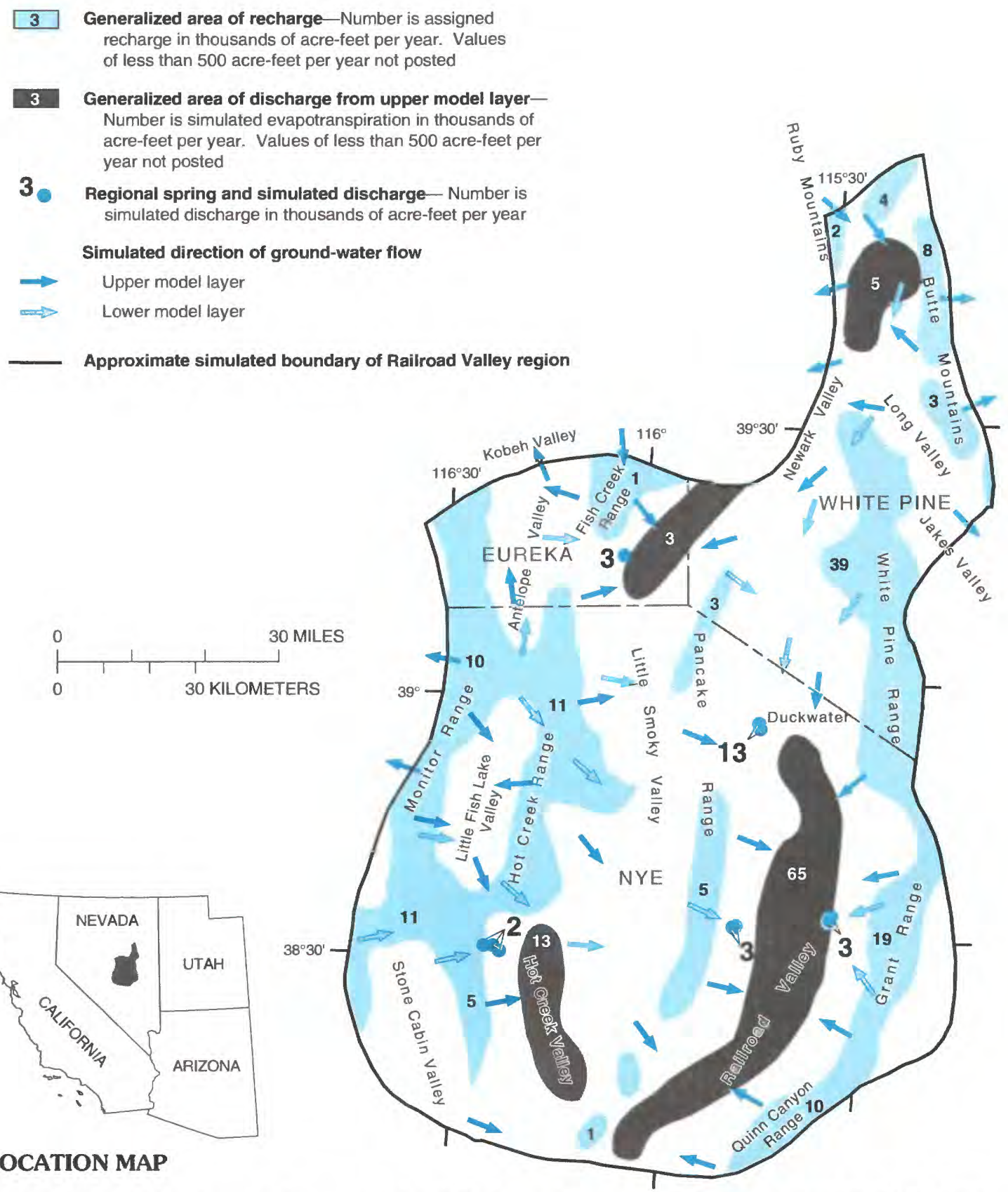

Figure 34.-Areas of assigned recharge, simulated discharge from upper model layer, simulated discharge from regional springs, and simulated direction of ground-water flow for both upper and lower model layers in Railroad Valley region. 
TABLE 7.-Simulated ground-water flow budget, Railroad Valley region

[All amounts are in acre-feet per year (acre-ft/yr), rounded to nearest 1,000 acre-ft/yr. Amounts of mountain recharge are assigned, as described in text section title "Estimates of Recharge"; all other listed amounts are determined from model simulation]

\section{Budget component and}

(in parentheses)

model layer involved

\section{INFLOW}

Mountain Recharge (upper)

132,000

Subsurface inflow from adjacent regions (both)

$a_{2,000}$

Subsurface inflow from adjacent subregions (both)

Total inflow 134,000

\section{OUTFLOW}

Evapotranspiration (upper)

Regional springs (lower)

Subsurface outflow to adjacent regions (both)

Subsurface outflow to

adjacent subregions (both)

Total outflow ${ }^{d}$

\footnotetext{
${ }^{a}$ From Bonneville region.

$b$ Includes evapotranspiration of flow from small springs that are assumed to be discharging from upper layer; does not include evapotranspiration of flow from regional springs that are simulated to be discharging from lower layer.

c Includes 8,000 acre-ft/yr to Death Valley region, 1,000 acre-ft/yr to Colorado River region, 4,000 acre- $\mathrm{ft} / \mathrm{yr}$ to Bonneville region, and 10,000 acre- $\mathrm{ft} / \mathrm{yr}$ to upper Humboldt River region.

d Total outflow does not equal total inflow due to rounding of individual values.
}

model cells in the Hot Creek Range were assigned lower transmissivities. This was not done because, during model calibration, the discharge in Little Fish Lake Valley was grouped with the discharge of Hot Creek Valley to reduce the number of comparisons between simulated and estimated discharge.

The simulated areal distribution of evapotranspiration in Little Smoky and Long Valleys agrees with the mapped areas of evapotranspiration (Harrill and others, 1988). In Little Smoky Valley, simulated evapotranspiration is at the north end of the valley (fig. 34), adjacent to the discharge from Fish Creek Spring. Simulated dis- charge in this area is about 6,000 acre-ft/yr (fig. 34 ), which is slightly more than the 5,200 acre$\mathrm{ft} / \mathrm{yr}$ estimated by Rush and Everett (1966a, p. 27). In Long Valley, simulated evapotranspiration is also at the north end (fig. 34); however, the quantity is about 3,000 acre-ft/yr more than the 2,200 acre-ft/yr estimated by Eakin (1961a, p. 23). The additional discharge in northern Long Valley represents flow from the adjacent Butte and Ruby Mountains.

No evapotranspiration is simulated in Antelope Valley (fig. 34), west of Little Smoky Valley, even though 4,200 acre-ft/yr is estimated by Rush and Everett (1964, p. 21). During model calibration, estimated discharge in Antelope Valley was grouped with that in Kobeh Valley. The model distribution of discharge in Antelope and Kobeh Valleys probably would agree more closely with the observed distribution if upper-layer cells in Antelope Valley were assigned lower values of transmissivity.

\section{DESCRIPTION OF GROUND-WATER FLOW}

Simulated ground-water flow is generally in the upper layer from recharge areas in the mountains to the adjacent valley floors (fig. 34). In the Railroad Valley region, about 68 percent of the total inflow is simulated through the upper layer. Downward flow from the upper layer to the lower layer totals 41,000 acre-ft/yr. Most of the flow in the lower layer is to regional springs and leakage to the upper layer on the floor of Railroad Valley. Of the simulated flow entering the lower layer from the upper layer, about 60 percent is discharged at regional springs.

In Railroad Valley, estimated discharge is 27,000 acre-ft/yr greater than estimated recharge, which led Van Denburgh and Rush (1974, p. 28) to suggest additional ground-water inflow from adjacent valleys west and north of Railroad Valley. The imbalance between recharge and discharge in Railroad Valley is also reflected in the model, where assigned recharge in the drainage basin is less than the simulated discharge. The difference is balanced by subsurface inflow from adjacent areas. Flow is simulated from the Monitor and Hot Creek Ranges toward southern Railroad Valley (fig. 34). This flow direction is consistent with the orientation of deep flow in both carbonate and volcanic rocks as reported by Dinwiddie and Schroder (1971, p. 62-64). Simulated underflow entering Railroad Valley from the west is about 7,600 acre- $\mathrm{ft} / \mathrm{yr}$, of which 4,900 acre-ft/yr is in the lower 
layer. Estimated flow from Hot Creek and southern Little Smoky Valleys to Railroad Valley is about 3,000 acre-ft/yr (Rush and Everett, 1966a, p. 26). Discharge to springs on the west side of Railroad Valley is simulated as flow from recharge in the Hot Creek Range, by way of southern Little Smoky Valley. Discharge to springs on the east side of Railroad Valley is simulated from the adjacent Grant Range (fig. 34).

In the model, flow to the large regional springs at Duckwater is mostly from the north (fig. 34). This flow is controlled by a zone of high transmissivities in the lower layer that extends from the north end of Long Valley to Muddy River Springs in southern Nevada (transmissivities there range from 0.006 to $0.66 \mathrm{ft}^{2} / \mathrm{s}$, as shown in fig. 25). About 16,000 acre-ft/yr is simulated as southward flow to the springs at Duckwater. More than 90 percent of this flow is from the northern White Pine Range. Simulated flow from the Pancake Range west of the springs is only $600 \mathrm{acre}-\mathrm{ft} / \mathrm{yr}$. Not all flow entering the model cell that represents the Duckwater regional springs is discharged as spring flow. Some deep flow (about 3,800 acre-ft/yr in the lower layer) continues southward to the playa in Railroad Valley. There, flow in the lower layer leaks upward into the upper layer near the north end of the playa where it is discharged as evapotranspiration. Whether deep flow through carbonate rocks continues southward from Duckwater Springs to the playa in Railroad Valley is unknown. In the model, southward flow from areas to the north is needed to balance simulated evapotranspiration with estimated evapotranspiration.

In Long Valley, estimated recharge exceeds estimated discharge (Eakin, 1961a, p. 1). Subsurface flow from Long Valley is postulated as moving either south to White River Valley (Eakin, 1961a, p. 1) or west to Newark Valley (Mifflin, 1968, p. 42). Both flow directions are shown by Harrill and others (1988). Simulated flow from Long Valley to Newark Valley is 12,700 acre-ft/yr; about 8,800 acre$\mathrm{ft} / \mathrm{yr}$ is simulated through the lower layer. In the lower layer, much of the ground-water flow is from Long Valley through eastern Newark Valley to the regional springs at Duckwater. Actual flow may differ from simulated flow because of uncertainties in the estimation of recharge and because hydraulic properties of the rocks are largely unknown.

The boundary between Railroad Valley region and upper Humboldt River region extends across northern Newark Valley to the western edge of Long Valley. Simulated flow from the Railroad Valley region to the upper Humboldt River region in Newark Valley through the upper and lower layers is 5,400 and 1,600 acre-ft/yr, respectively. Simulated flow moving across this boundary is mostly discharged as evapotranspiration in Newark Valley.

The boundary between Railroad Valley and upper Humboldt River region also extends across northern Antelope Valley and southern Fish Creek Range (fig. 34). Ninety-eight percent of the flow across this part of the boundary is simulated in the upper layer. Outflow of 4,900 acre-ft/yr from the Railroad Valley region is simulated from Antelope Valley to Kobeh Valley. Inflow of 1,800 acre$\mathrm{ft} / \mathrm{yr}$ is simulated in the Fish Creek Range.

Simulated flow to Fish Creek Spring in northern Little Smoky Valley is mostly from the west and south (fig. 34), where transmissivities in the lower layer are greater than $0.006 \mathrm{ft}^{2} / \mathrm{s}$ (fig. 25). Simulated flow from the west is 1,600 acre-ft/yr, mostly from Antelope Valley. (Rush and Everett [1966a, p. 23, 25] have postulated that Antelope Valley is the source of the spring flow.) Simulated flow from the south is 1,100 acre-ft/yr, mostly from the northern Hot Creek Range. Only 50 acre$\mathrm{ft} / \mathrm{yr}$ of spring flow is simulated from the north and the northeast in the adjacent Fish Creek Range. In Antelope Valley, ground-water flow in the upper layer of about 4,900 acre-ft/yr is simulated northward to Kobeh Valley.

The simulated flow to the spring from the west and south, although consistent with the general directions of ground-water flow on the basis of available water-level data, must cross the OregonNevada lineament that trends southeastward through at least part of the Railroad Valley region (the lineament is shown in fig. 22B). Areas of observed ground-water discharge in Antelope and Kobeh Valleys begin upgradient from this lineament, suggesting that it may act as a barrier to ground-water flow northwest of the springs. The lineament is marked by a zone of closely spaced northwest-trending faults that are segmented by many northeast-trending basin-andrange faults (Stewart and others, 1975, p. 266). Northwest of Antelope Valley, the lineament is associated with a subsurface magnetic body that may be related to low-permeability rocks (fig. $24 A$; Plume, 1995). The degree to which the lineament impedes eastward and northward flow from Antelope Valley and northern Hot Creek Range, respectively, is unknown. If structures along the lineament are a barrier to flow, then the most likely alternative source for discharge at Fish Creek Spring is the Fish Creek Range, and the distribution of transmissivities in the lower model layer would be different from those simulated. 


\section{UPPER HUMBOLDT RIVER REGION}

The upper Humboldt River region, in the northwestern part of the study area (fig. 24), encompasses about $7,200 \mathrm{mi}^{2}$. It includes two deepflow subregions in the lower layer--Diamond and Humboldt (fig. 35) -and all or part of 10 shallow-flow regions in the upper layer (fig. 23). The region described herein does not coincide with the upper basin of the Humboldt River drainage as discussed by Eakin and Lamke (1966, p. 17); their area incorporates the entire $5,000 \mathrm{mi}^{2}$ drainage basin of the river east of Palisade and does not include the area corresponding to the Diamond subregion.

Discussion of ground-water flow in this region is limited to the simulation of (1) flow from mountains to adjacent valley floors, including those in the Humboldt River Valley, and (2) interbasin flow. Head-dependent flow boundaries (fig. 9) are used in the model to represent the Humboldt River and the major tributaries that enter the model area from the north. These boundaries are used to simulate net leakage, either as discharge to the river or as recharge from the river. Net flow depends on the relation of simulated water levels in the upper layer to a specified head that represents the river stage. Tributaries that originate within the region (most of which are south of the Humboldt River) are not simulated as headdependent flow boundaries because they are generally gaining streams and ground-water seepage to them is simulated in the model as evapotranspiration. Most of the net leakage at the headdependent flow boundaries is simulated as ground-water discharge (table 8). For areas along the Humboldt River, this discharge is combined with simulated evapotranspiration from the upper layer, as shown in figure 35 . The percolation of surface water from the Humboldt River and its tributaries to the shallow ground-water body in the alluvium is not generally included in the model, because much of this percolation is discharged as nearby evapotranspiration and, thus, is considered local flow.

\section{INFLOW}

Simulated inflow to the upper Humboldt River region is 189,000 acre- $\mathrm{ft} / \mathrm{yr}$, including 174,000 acre$\mathrm{ft} / \mathrm{yr}$ as recharge assigned to cells in the upper model layer, 3,000 acre-ft/yr from head-dependent flow boundaries in the upper layer associated with the river and major tributaries to the north, and
12,000 acre-ft/yr as subsurface inflow in both layers from adjacent regions (table 8). Major recharge areas for the region include the East Humboldt Range, Ruby Mountains, and Diamond Mountains in the east; the Roberts Mountains and Sulphur Spring Range in the central part; and the Simpson Park and Cortez Mountains in the west (fig. 35). Small quantities of recharge also are assigned to several other mountain ranges. Of the subsurface flow simulated from adjacent regions, most $(10,000$ acre-ft/yr) is from the Railroad Valley region, primarily through the upper model layer.

\section{OUTFLOW}

Simulated outflow from the upper Humboldt River region is 188,000 acre-ft/yr, including 131,000 acre-ft/yr as evapotranspiration from the upper layer, 28,000 acre-ft/yr as discharge to headdependent flow boundaries from the upper layer associated with the Humboldt River, 4,000 acre$\mathrm{ft} / \mathrm{yr}$ as flow to regional springs in the lower layer, and 25,000 acre-ft/yr as subsurface flow in both layers to the Bonneville region (table 8). Areas of simulated discharge are shown in figure 35 . The major areas are along the Humboldt River in the north; in Huntington and Newark Valleys in the east; in Kobeh, Diamond, and Pine Valleys in the central part; and in Grass and Crescent Valleys in the west. Subsurface flow to the Bonneville region is along the crest of the Ruby Mountains. Discharge to regional springs is on the west side of Diamond Valley in the Diamond subregion (fig. 35).

\section{DESCRIPTION OF SUBREGIONS}

DIAMOND SUBREGION

The Diamond subregion, in the southern part of the upper Humboldt River region (fig. 35), encompasses about $2,100 \mathrm{mi}^{2}$. It differs from the flow system delineated by Harrill and others (1988) as their system includes the drainage areas of Monitor and Antelope Valleys and excludes Newark Valley. Although Monitor and Antelope Valleys are not part of the Diamond subregion, flow is simulated through the upper layer from these valleys to Kobeh Valley. The subregion includes all or part of three shallow-flow regions in the upper layer (fig. 23). The shallow-flow regions generally correspond to drainage areas for Newark, Kobeh, and Diamond Valleys. 
Inflow to the subregion is from recharge assigned to cells in the upper model layer and subsurface inflow from the Railroad Valley region. Recharge totals 61,000 acre-ft/yr (table 8), mostly in the Diamond and Roberts Mountains and the southern half of the Sulphur Spring Range. An additional 10,000 acre- $\mathrm{ft} / \mathrm{yr}$ is simulated as subsurface flow from the Railroad Valley region, and 1,000 acre- $\mathrm{ft} / \mathrm{yr}$ from the Death Valley region. Of the subsurface flow from Railroad Valley, about $6,400 \mathrm{acre}-\mathrm{ft} / \mathrm{yr}$ is along the east and south sides of Newark Valley and about 4,900 acre-ft/yr is

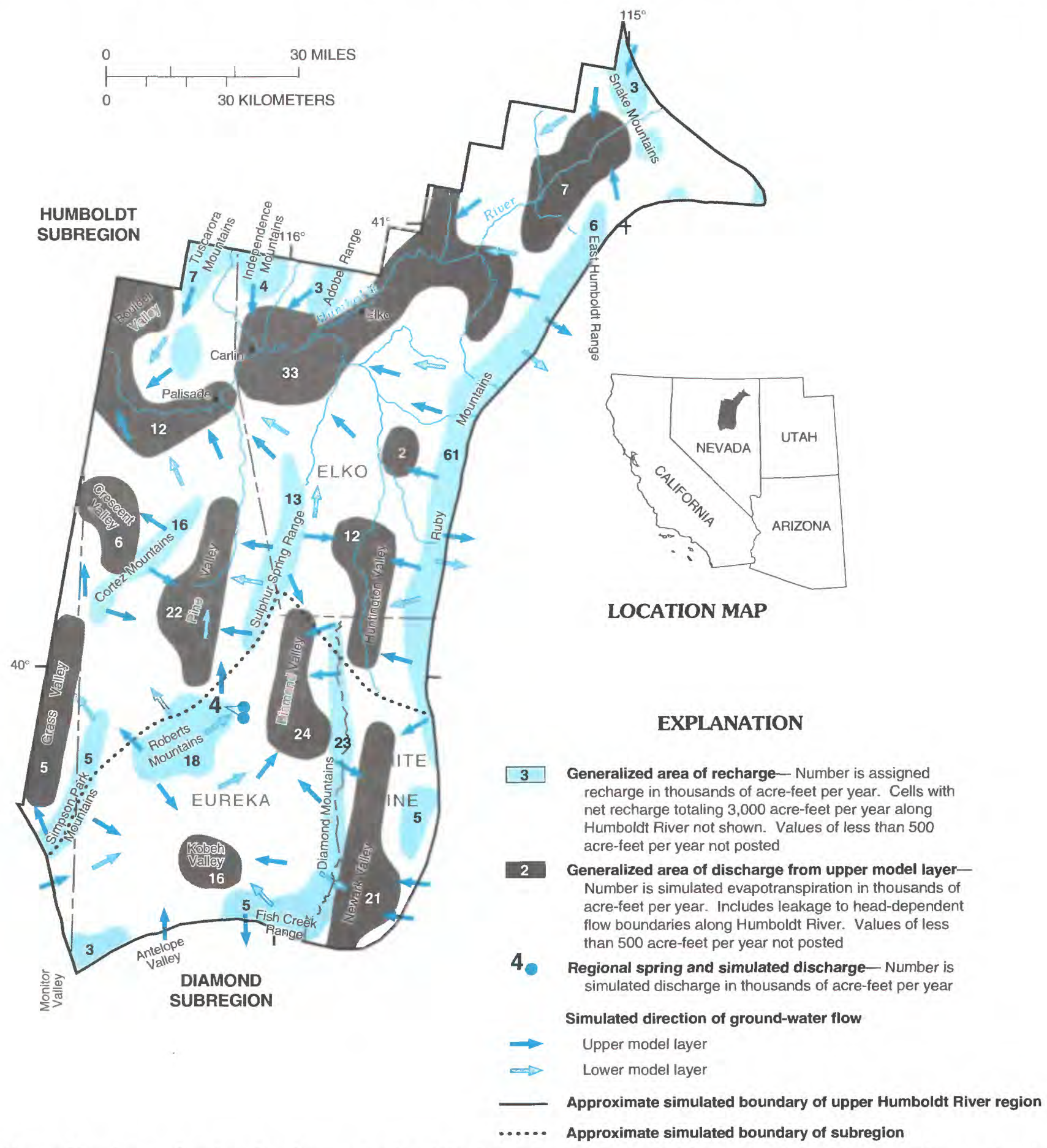

FIGURE 35.-Areas of assigned recharge, simulated discharge from upper model layer, simulated discharge from regional springs, and simulated direction of ground-water flow for both upper and lower model layers in upper Humboldt River region. 
TABLE 8.-Simulated ground-water flow budget, Humboldt River region

[All amounts are in acre-feet per year (acre-ft/yr), rounded to nearest 1,000 acre-ft/yr. Amounts of mountain recharge are
assigned, as described in text section title "Estimates of Recharge"; all other listed amounts are determined from model simulation]

\begin{tabular}{|c|c|c|c|}
\hline $\begin{array}{l}\text { Budget component and } \\
\text { (in parentheses) } \\
\text { model layer involved }\end{array}$ & $\begin{array}{l}\text { Diamond } \\
\text { subregion }\end{array}$ & $\begin{array}{l}\text { Humboldt } \\
\text { subregion }\end{array}$ & $\begin{array}{l}\text { Entire upper } \\
\text { Humboldt River } \\
\text { region }\end{array}$ \\
\hline \multicolumn{4}{|l|}{ INFLOW } \\
\hline Mountain recharge (upper) & 61,000 & 113,000 & 174,000 \\
\hline Subsurface inflow from adjacent regions (both) & $a_{11,000}$ & ${ }^{b} 1,000$ & 12,000 \\
\hline $\begin{array}{l}\text { Subsurface inflow from } \\
\text { adjacent subregions (both) }\end{array}$ & 0 & ${ }^{c} 6,000$ & (d) \\
\hline Leakage & 0 & $e_{3,000}$ & e 3,000 \\
\hline Total inflow & 72,000 & 123,000 & 189,000 \\
\hline \multicolumn{4}{|l|}{ OUTFLOW } \\
\hline Evapotranspiration (upper) ${ }^{f}$ & 61,000 & 70,000 & 131,000 \\
\hline Regional springs (lower) & 4,000 & 0 & 4,000 \\
\hline $\begin{array}{l}\text { Subsurface outflow to } \\
\text { adjacent regions (both) }\end{array}$ & 0 & $\boldsymbol{g}_{25,000}$ & 25,000 \\
\hline $\begin{array}{l}\text { Subsurface outflow to } \\
\text { adjacent subregions (both) }\end{array}$ & $h_{6,000}$ & 0 & $(d)$ \\
\hline Leakage (upper) & 0 & $i_{28,000}$ & $i_{28,000}$ \\
\hline Total outflow ${ }^{j}$ & 71,000 & 123,000 & 188,000 \\
\hline
\end{tabular}

ancludes 10,000 acre-ft/yr from Railroad Valley region and 1,000 acre-ft/yr from Death Valley region.

$b^{b}$ Includes 600 acre-ft/yr from Bonneville region and 400 acre- $\mathrm{ft} / \mathrm{yr}$ from Death Valley region.

c From Diamond subregion.

d Net flow among subregions within upper Humboldt River region is zero.

e From Humboldt River and selected tributaries.

$f$ Includes evapotranspiration of flow from small springs that are assumed to be discharging from upper layer; does not include evapotranspiration of flow from regional springs that are simulated to be discharging from lower layer.

$\boldsymbol{g}$ To Bonneville region.

$h^{h}$ To Humboldt subregion.

$i$ To Humboldt River and selected tributaries.

$j$ Total outflow does not always equal total inflow due to rounding of individual values.

simulated as flowing northward from Antelope Valley into Kobeh Valley in the upper layer (fig. 35 ); about 1,200 acre-ft/yr is simulated as southward flow from the Fish Creek Range at the south end of Diamond Valley into the Railroad Valley region.

Total simulated outflow from the subregion is 71,000 acre-ft/yr. Simulated evapotranspiration from the upper model layer and discharge to regional springs in Diamond Valley from the lower layer total about 65,000 acre-ft/yr, which is approximately the same as the estimated discharge of 61,000 to 63,500 acre-ft/yr from Newark, Kobeh, and Diamond Valleys: 16,000 to 18,500 acre-ft/yr in Newark Valley (Eakin, 1960, p. 15, 16), 15,000 acre-ft/yr in Kobeh Valley (Rush and Everett, 1964, p. 20), and 30,000 acre-ft/yr in Diamond Valley (Harrill, 1968, p. 33).

Ground-water flow in the subregion is primarily from recharge areas in the mountains to discharge areas on the valley floors. About 83 percent of the total inflow to the subregion is simulated through the upper layer. Downward flow from the upper layer to the lower layer totals 9,500 acre$\mathrm{ft} / \mathrm{yr}$. Of the flow in the lower layer, 4,400 acre$\mathrm{ft} / \mathrm{yr}$ is discharged at Shipley Hot Spring and Bailey Spring on the west side of Diamond Valley (fig. 35, table 1). Transmissivities simulated in the lower layer are less than $0.006 \mathrm{ft}^{2} / \mathrm{s}$ throughout most of the subregion (fig. 20B); southwest 
of the regional springs, in contrast, values range from 0.006 to $0.18 \mathrm{ft}^{2} / \mathrm{s}$ (fig. 25). Simulated transmissivities in the upper layer are generally less than $0.18 \mathrm{ft}^{2} / \mathrm{s}$, except in Kobeh and Diamond Valleys where they range from 0.18 to $0.66 \mathrm{ft}^{2} / \mathrm{s}$ (fig. $20 A$ ). Estimated transmissivities for basin fill, based on pumping tests at six water wells in southern Diamond Valley, range from 0.04 to $0.4 \mathrm{ft}^{2} / \mathrm{s}$ $(27,000$ to $250,000 \mathrm{gal} / \mathrm{d} / \mathrm{ft}$; Harrill, 1968, p. 15). These values are in the same range as those simulated in the model.

Simulated ground-water flow to Shipley Hot Spring and Bailey Spring on the west side of Diamond Valley (table 1, fig. 35) is from the Roberts Mountains southwest of the springs. This is the same source area for an estimated 9,000 acre-ft/yr of subsurface flow from Garden Valley (Harrill, 1968, p. 25, 26)-a small basin on the west flank of the Roberts Mountains that is tributary to Pine Valley (not shown in fig. 35). The estimate is based on an imbalance between recharge and discharge in Garden Valley and a hydraulic gradient of 25 to $120 \mathrm{ft} / \mathrm{mi}$ from that valley to Diamond Valley.

\section{HUMBOLDT SUBREGION}

The Humboldt subregion encompasses about $5,100 \mathrm{mi}^{2}$. It includes all or part of six shallowflow regions in the upper layer (fig. 23). The subregion generally corresponds to the flow system of Harrill and others (1988) along the east and south boundaries, except they exclude Grass Valley. To the north and west, their flow system includes basins tributary to the Humboldt River that extend beyond the modeled area. Simulated inflow to the subregion is 123,000 acre-ft/yr, of which $113,000 \mathrm{acre}-\mathrm{ft} / \mathrm{yr}$ is recharge assigned to cells in the upper model layer, 3,000 acre-ft/yr is flow from head-dependent flow boundaries in the upper layer, 6,000 acre-ft/yr is subsurface flow from the Diamond subregion, and 1,000 acre-ft/yr is flow from the Bonneville and Death Valley regions (table 8). Simulated outflow from the Humboldt subregion includes 70,000 acre-ft/yr as evapotranspiration from the upper layer, 28,000 acre- $\mathrm{ft} / \mathrm{yr}$ as leakage to head-dependent flow boundaries in the upper layer, and 25,000 acre-ft/yr as subsurface flow to the Bonneville region. The latter is from model cells along the crests of the Ruby Mountains, where horizontal flow in both layers is eastward and westward (fig. 35). Model cells along the crests are included in the water-budget computation for the upper Humboldt River region.
Thus, eastward flow along the crests of these ranges is accounted for as simulated subsurface outflow to the Bonneville region; about 11,000 acre$\mathrm{ft} / \mathrm{yr}$ is simulated through the upper layer, the remaining 14,000 acre-ft/yr is simulated through the lower layer.

Ground-water flow in the subregion is simulated from recharge areas in the mountain ranges to discharge areas on the adjacent valley floors and to the Humboldt River (fig. 35). About 73 percent of the total inflow to the subregion is simulated through the upper layer. Transmissivities in the lower layer are less than $0.006 \mathrm{ft}^{2} / \mathrm{s}$ throughout the subregion, with values less than 0.0006 $\mathrm{ft}^{2} / \mathrm{s}$ on the west side (fig. $20 B$ ). Transmissivities in the upper layer are generally less than 0.006 $\mathrm{ft}^{2} / \mathrm{s}$ in the northern Ruby Mountains and East Humboldt Range, which corresponds to the lowpermeability rocks that crop out in these mountains (Plume, 1995), and between 0.006 and 0.18 $\mathrm{ft}^{2} / \mathrm{s}$ in the valley lowlands and areas north of the Humboldt River (fig. 20A).

The generally low transmissivities in the lower layer may be related to thinning of the Paleozoic carbonate rocks. Outcrops of deep-water clastic rocks, chert, and volcanic rocks of Triassic to Cambrian age become increasingly abundant west of the Ruby Mountains, and correspondingly, outcrops of Paleozoic carbonate rocks become less abundant (Plume and Carlton, 1988). Locally, however, volcanic and carbonate rocks in the subregion may be highly permeable and may transmit moderate quantities of ground water to discharge points near the river. The springs near Carlin may be an example of this.

In valleys south of the Humboldt River, simulated evapotranspiration is $47,000 \mathrm{acre}-\mathrm{ft} / \mathrm{yr}$, including: 14,000 acre- $\mathrm{ft} / \mathrm{yr}$ for two areas in Huntington Valley, 22,000 acre-ft/yr in Pine Valley, 6,000 acre-ft/yr from Crescent Valley, and 5,000 acre-ft/yr in Grass Valley (fig. 35). Estimated evapotranspiration in these valleys totals 57,000 acre-ft/yr: 21,000 acre-ft/yr in Huntington Valley area (Rush and Everett, 1966b, p. 21, 22), 24,000 acre-ft/yr in Pine Valley (Eakin, 1961b, p. 22, includes 5,000 acre-ft/yr as leakage to Pine Creek), 12,000 acre-ft/yr in Crescent Valley (Zones, 1961, p. 21), and 12,000 acre-ft/yr in Grass Valley (Everett and Rush, 1966, p. 16). Crescent and Grass Valleys are on the edge of the modeled area and recharge from mountain ranges on the west sides of the valleys is not simulated. Consequently, the simulated discharge in these valleys is appreciably less than the estimated quantity. 
Total simulated discharge (as evapotranspiration and leakage to head-dependent flow boundaries) along the Humboldt River is 52,000 acre-ft/yr (fig. 35). This quantity represents only a fraction of the total estimated evapotranspiration and streamflow in the Humboldt River valley above Palisade (Eakin and Lamke, 1966, p. 59, 60). Simulation of regional ground-water flow with the model did not account for the local circulation of water adjacent to the Humboldt River; rather, the model is designed to assess the potential for regional flow from distant sources to regional discharge areas. In the upper Humboldt River region, the quantity of simulated deep flow (flow through the lower model layer) to the Humboldt River is small (a few thousand acre-ft/yr) compared to local flow between the river and its alluvium.

\section{POTENTIAL USES OF MODEL}

The ground-water flow model of the carbonate-rock province is unlike most models in that the extent of aquifers and their hydraulic properties are generally unknown in the province; thus, the model greatly simplifies flow through a complex geologic region. Simulation results are based on assuming recharge to the province is known with the distribution of transmissivities simulated to match the general distribution of water levels and estimates of discharge. However, water levels in consolidated rocks are generally unknown, and estimates of recharge and discharge are known only approximately. Consequently, other, equally valid distributions of transmissivities may be found that permit the model to be calibrated to the existing water-level data and estimates of recharge and discharge. The model may be best suited for:

- Simulating alternative transmissivity distributions to evaluate potential source areas of regional springs,

- Simulating the effects of differing recharge rates on regional ground-water flow, and

- Simulating the effects of changing location of discharge on regional ground-water flow.

Therefore, the potential uses of the model are limited. The model is not suited to predict accurate water-level declines that would result from pumping ground water in the province. Also, the model is not suited to predict the accurate rate of change in natural discharge caused by pumping, because the model has not been calibrated to any transient simulations.

\section{SUMMARY AND CONCLUSIONS}

This report describes the results of a computer-model-based analysis of regional groundwater flow in the eastern Great Basin, a $100,000-\mathrm{mi}^{2}$ area that lies mostly in eastern $\mathrm{Ne}$ vada and western Utah, with small parts in northwestern Arizona, eastern California, and southern Idaho. The original version of this report, published in 1991, presented results that subsequently proved to be adversely affected by a transpositional error in the computer data files that define the model-cell dimensions. This error produced an unintended regional anisotropy in hydraulic conductivity. The results reported herein constitute a reanalysis of regional flow after the transposition was corrected and the computer model recalibrated.

Ground-water flow in the eastern Great Basin has been evaluated as part of the U.S. Geological Survey's Great Basin Regional Aquifer-System Analysis. The area is referred to as the carbonate-rock province because, during the Paleozoic era, thick sequences of limestone and dolomite were deposited in a shallow sea that inundated the area. Since then, many episodes of sediment deposition, volcanic activity, erosion, and tectonic deformation by both compressional and extensional forces have altered the extent and thickness of the carbonate rocks. The present-day physiography, which is characterized by north- to northeast-trending mountain ranges separated by intervening valleys that are partly filled with sedimentary deposits eroded from the adjacent mountains, is the result of normal faulting caused by extension that began about 20 million years ago. Relief between the block-faulted mountains and the adjacent valley floors ranges from $1,000 \mathrm{ft}$ to more than $7,000 \mathrm{ft}$.

Shallow ground-water reservoirs in the basin fill supply most of the current (1992) pumpage from wells in this geologically complex terrain. Aquifers in the underlying carbonate rocks are largely undeveloped; regionally, however, these aquifers are important because they provide an avenue for interbasin ground-water flow. The source of ground water in the province is precipitation, most of which falls in the higher mountain ranges. Ground-water discharge is mostly by evapotranspiration in the low parts of the many valleys. Some ground water also discharges from small, local springs. Such springs are fed by recharge that originates nearby. In contrast, ground water discharging at larger, regional springs 
issuing from the carbonate-rock aquifers originates in distant mountain ranges.

Ground-water flow in the province is conceptualized as consisting of two components: a relatively shallow one in which the flow is from mountain ranges to adjacent valleys, and a deeper one in which the ground water is transmitted through carbonate rocks beneath mountain ranges and valleys to discharge areas at distant springs or terminal sinks. The maximum depth of flow in the province is unknown, but freshwater has been detected at depths as great as $10,000 \mathrm{ft}$. A three-dimensional ground-water flow model was used to simulate the concept of shallow flow systems superimposed over deeper flow systems and to evaluate regional flow. The modeled area is divided into rectangular cells, $5 \mathrm{mi}$ wide and 7.5 $\mathrm{mi}$ long, that are elongate in a northnortheastward direction. Two model layers are used to simulate the shallow and deeper flow systems.

The conceptualization and simulation of regional ground-water flow includes the following simplifying assumptions: (1) Fractures and solution openings in consolidated rocks can be represented on a regional scale as a porous medium. (2) Darcy's Law is applicable on a regional scale to flow through the fractures and solution openings and across abrupt changes in lithology. (3) Steady-state conditions exist, in which estimates of present-day recharge equal estimates of discharge (the discharge estimates used for each valley are based on conditions prior to ground-water development). (4) Horizontal transmissivity is heterogeneous in the region, but it is homogenous and isotropic within each $37.5-\mathrm{mi}^{2}$ model cell. (5) Recharge is from precipitation in the mountain ranges and is based on previously published estimates. (6) Rivers and lakes that border the province, as well as the Death Valley playa, can be either a source or a sink for ground-water flow. (7) Discharge from regional springs is known, and flow to the springs is through carbonate rocks. (8) Spring flow not simulated as discharging from carbonate rocks is included as part of the discharge from shallow ground water. Although these assumptions are probably valid for parts of the province, the validity of each assumption for the entire area is not known. Because of the uncertainty of these assumptions and because the extent, thickness, and hydraulic properties of the carbonate aquifers throughout most of the province are largely unknown, simulation results do not perfectly replicate actual ground-water flow in the province. The results do, however, provide a simplified concept of the distribution of recharge, discharge, and flow in the province within the limitations of current understanding and the limitations of the model simulations.

The computer model was calibrated by adjusting transmissivities of cells in both model layers and vertical leakances between layers during repeated simulations. Calibration proceeded until simulated water levels and simulated discharge as evapotranspiration and regional-spring flow agreed with available water levels in most places, with the mapped distribution and estimated quantity of evapotranspiration, and with the estimated flow at regional springs. The magnitude of the estimated transmissivities and vertical leakances in the model is dependent upon the quantity of recharge used in the simulation. Estimates of recharge are approximate and could differ from actual recharge by 100 percent or more. Therefore, the estimated transmissivities and leakances include an uncertainty equal to or greater than that of the estimated recharge. Additional uncertainty in the distribution of transmissivities and leakances results from the scarcity of available water-level data (particularly for the carbonaterock aquifers), the lack of information on the extent and thickness of the basin-fill and carbonate-rock aquifers, and the lack of knowledge on the distribution of recharge. Because of the uncertainty in the transmissivities and vertical leakances, other distributions may adequately simulate water levels and discharge in the province. In addition, the estimated transmissivities should be considered only on a regional basis because the values represent an average for all rocks and deposits included within the $37.5-\mathrm{mi}^{2}$ area of a model cell. The hydraulic properties of the various rocks and deposits within even a single cell can vary by several orders of magnitude.

In the upper model layer, transmissivities range from 0.000022 to $0.22 \mathrm{ft}^{2} / \mathrm{s}$. Transmissivities are generally greater than $0.006 \mathrm{ft}^{2} / \mathrm{s}$ for cells corresponding to basin fill and carbonate rocks and are less than $0.006 \mathrm{ft}^{2} / \mathrm{s}$ for cells corresponding to other consolidated rocks (which are assumed to be of low permeability). Lowest transmissivities are simulated in the Great Salt Lake Desert, where an extensive body of ground water is saline and the circulation of freshwater is minimal.

In the lower model layer, estimated transmissivities range from 0.000033 to $0.66 \mathrm{ft}^{2} / \mathrm{s}$. Transmissivities greater than $0.006 \mathrm{ft}^{2} / \mathrm{s}$ are simulated in the vicinity of regional springs or in areas where 
ground-water budgets indicate interbasin flow. These zones of higher transmissivity may be related to places in the province where thick sequences of Paleozoic carbonate rocks are still present. The highest transmissivities are simulated in narrow bands associated with regional springs in the White River Valley in eastern Nevada, the Muddy River Springs in southern Nevada, and Fish Springs in west-central Utah. Transmissivities less than $0.006 \mathrm{ft}^{2} / \mathrm{s}$ are simulated throughout much of the province. Lowest transmissivities are simulated for the Great Salt Lake Desert, for Death Valley, and for the extreme southern end of the province.

Only one of several extensive east-west-trending lineaments could be correlated with a marked change in the simulated and measured water-level trends. This lineament, called the transverse crustal boundary, extends across southern Nevada. It generally corresponds to the southern extent of Cenozoic volcanism in the province, to a considerable southward decline in the altitude of the valley floor, to a change in gravity, and to the location of left-lateral shears. Except for a narrow zone of high transmissivities in eastern $\mathrm{Ne}$ vada, assigned values in the lower model layer are less than $0.006 \mathrm{ft}^{2} / \mathrm{s}$ along the lineament.

The lack of correlation of marked changes in simulated water levels and transmissivities, as well as observed water-level trends, across other lineaments north of the transverse crustal boundary might be due to disruption of the lineaments by younger faulting. However, several regional springs are near the lineaments, which suggests that segments along some of the lineaments may restrict regional ground-water flow.

The model simulates the concept of numerous shallow-flow regions superimposed upon fewer deep-flow regions. A total of 45 shallow-flow regions are identified in the upper model layer on the basis of horizontal flow between cells. In the lower layer, flow is grouped into deep-flow regions and subregions. A total of 17 deep-flow subregions are delineated, also on the basis of horizontal flow between cells. The subregions are, in turn, grouped into five deep-flow regions on the basis of areas having simulated water levels that generally decline toward one of five regional discharge areas. These are named the Death Valley, Colorado River, Bonneville, Railroad Valley, and upper Humboldt River regions. Simulated water levels are generally highest in southwestern Utah and east-central Nevada, where altitudes of the valleys floors are highest. From this area, water levels gener- ally decrease northward toward discharge areas in the upper Humboldt River and Bonneville regions and southward toward discharge areas in the Colorado River and Death Valley regions. Within the area of high water levels in east-central Nevada, some of the ground water flows to a terminal sink in Railroad Valley.

Water budgets for each of the deep-flow regions are summarized in table 9 . The budgets include flow within the overlying shallow-flow regions. The budgets list cross-boundary flow between regions because cells that straddle a flowregion boundary are assigned to only one of the two regions and because simulated flow in the shallow-flow regions is not everywhere in the same direction as that in the underlying deep-flow regions.

Most of the simulated flow is in the upper model layer. Total simulated inflow is about 1.5 million acre-ft/yr (about 3 percent of the total precipitation), with all but 3,000 acre-ft/yr assigned as recharge to the mountains (table 9). This inflow does not include recharge that is discharged locally-that is, within the same $37.5-\mathrm{mi}^{2}$ model cell. If this recharge were included, the estimated total inflow would be considerably more. Simulated outflow is mostly from the upper layer as evapotranspiration (about 1.2 million acre-ft/yr) and as leakage to surface-water bodies and to the Death Valley playa (about 100,000 acre-ft/yr). Most of the simulated flow in the lower layer is in areas of high transmissivities. Flow is downward in recharge areas, then lateral to regional springs or to areas of discharge from the upper layer. Total simulated flow in the lower layer is 428,000 acre$\mathrm{ft} / \mathrm{yr}$, or only 28 percent of total inflow. About half the flow through the lower layer $(211,000$ acre$\mathrm{ft} / \mathrm{yr}$ ) is simulated as discharge to regional springs. This simulated total is only 0.5 percent more than the estimated total for the regional springs.

Simulated regional-spring flow is extremely sensitive to changes in transmissivities in both layers and to changes in vertical leakance between layers. For example, increasing transmissivities in the lower layer between Ash Meadows in Amargosa Desert and Death Valley results in less spring flow at Ash Meadows and greater flow to Death Valley. Similar results are simulated at Muddy River Springs in southern Nevada and Fish Springs in west-central Utah when transmissivities are increased downgradient from the springs. Even minor changes to the assigned hydraulic properties can result in changes to the discharge at regional springs. The final assigned distribution 
TABLE 9.-Simulated ground-water flow budgets for five deep-flow regions of modeled area

[All amounts are in acre-feet per year (acre-ft/yr), rounded to nearest 1,000 acre-ft/yr. Amounts of mountain recharge are assigned, as described in text section title "Estimates of Recharge"; all other listed amounts are determined from model simulation]

\begin{tabular}{|c|c|c|c|c|c|c|}
\hline $\begin{array}{l}\text { Budget component and } \\
\text { (in parentheses) } \\
\text { model layer involved }\end{array}$ & $\begin{array}{l}\text { Death } \\
\text { Valley } \\
\text { region }\end{array}$ & $\begin{array}{l}\text { Colorado } \\
\text { River } \\
\text { region }\end{array}$ & $\begin{array}{l}\text { Bonneville } \\
\text { region }\end{array}$ & $\begin{array}{l}\text { Railroad } \\
\text { Valley } \\
\text { region }\end{array}$ & $\begin{array}{l}\text { Upper } \\
\text { Humboldt } \\
\text { River } \\
\text { region }\end{array}$ & $\begin{array}{c}\text { Entire } \\
\text { modeled } \\
\text { area }\end{array}$ \\
\hline \multicolumn{7}{|l|}{ INFLOW } \\
\hline Mountain recharge (upper) & 161,000 & 202,000 & 855,000 & 132,000 & 174,000 & $1,524,000$ \\
\hline $\begin{array}{l}\text { Subsurface inflow from } \\
\text { adjacent regions (both) }\end{array}$ & $a_{16,000}$ & ${ }^{b} 5,000$ & $c_{34,000}$ & ${ }^{d} 2,000$ & $e_{12,000}$ & \\
\hline Leakage (upper) & 0 & 0 & 0 & 0 & $g_{3,000}$ & 3,000 \\
\hline Total inflow & 177,000 & 207,000 & 889,000 & 134,000 & 189,000 & $1,527,000$ \\
\hline \multicolumn{7}{|l|}{ OUTFLOW } \\
\hline Evapotranspiration $^{h}$ (upper) & 147,000 & 91,000 & 758,000 & 86,000 & 131,000 & $1,213,000$ \\
\hline Regional springs (lower) & 22,000 & 97,000 & 64,000 & 24,000 & 4,000 & 211,000 \\
\hline $\begin{array}{l}\text { Subsurface outflow to } \\
\text { adjacent regions (both) }\end{array}$ & $i_{3,000}$ & $j_{10,000}$ & $k_{8,000}$ & $l_{23,000}$ & $m_{25,000}$ & $(f)$ \\
\hline Leakage (upper) & $n_{8,000}$ & o 7,000 & p 59,000 & 0 & $q_{28,000}$ & 102,000 \\
\hline Total outflow $r$ & 180,000 & 205,000 & 889,000 & 133,000 & 188,000 & $1,526,000$ \\
\hline
\end{tabular}

$a$ Includes 8,000 acre-ft/yr from Colorado River region and 8,000 acre-ft/yr from Railroad Valley region.

${ }^{b}$ Includes 2,000 acre-ft/yr from Bonneville region, 1,000 acre-ft/yr from Railroad Valley region, and 2,000 acre$\mathrm{ft} / \mathrm{yr}$ from Death Valley region.

${ }^{c}$ Includes 4,000 acre-ft/yr from Railroad Valley region, 25,000 acre-ft/yr from upper Humboldt River region, and 5,000 acre-ft/yr from Colorado River region.

${ }^{d}$ From Bonneville region.

${ }^{e}$ Includes 10,000 acre-ft/yr from Railroad Valley region, 1,400 acre-ft/yr from Death Valley region, and 600 acre$\mathrm{ft} / \mathrm{yr}$ from Bonneville region.

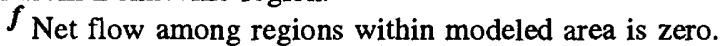

$\boldsymbol{g}$ From Humboldt River and selected tributaries.

$\boldsymbol{h}$ Includes evapotranspiration of flow from small springs that are assumed to be discharging from upper layer; does not include evapotranspiration from regional springs that are simmulated to be discharging from lower layer.

$i$ Includes 1,000 acre-ft/yr to upper Humboldt River region and 2,000 acre-ft/yr to Colorado River region.

$j$ Includes 2,000 acre-ft/yr to Bonneville region and 8,000 acre-ft/yr to Death Valley region.

${ }^{k}$ Includes 5,000 acre-ft/yr to Colorado River region, 2,000 acre-ft/yr to Railroad Valley region, and 1,000 acre-ft/yr to upper Humboldt River region.

Includes 8,000 acre-ft/yr to Death Valley region, 10,000 acre-ft/yr to upper Humboldt River region, 4,000 acre-ft/yr to Bonneville region, and 1,000 acre-ft/yr to Colorado River region.

$\boldsymbol{m}$ To Bonneville region.

$n$ To Death Valley playa.

o Includes 5,000 acre-ft/yr to Virgin River and 2,000 acre-ft/yr to Lake Mead and Colorado River.

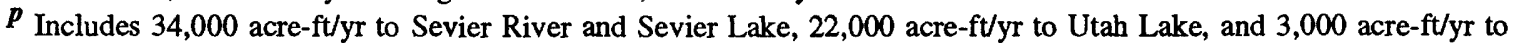
Great Salt Lake.

$q$ To Humboldt River and selected tributaries.

$\boldsymbol{r}$ Total outflow does not always equal total inflow due to rounding of individual values.

of transmissivities and vertical leakances results in simulated water levels, regional-spring flows, and evapotranspiration rates that reasonably du- plicate measured and estimated values. However, other combinations of transmissivities and vertical leakances may be possible that also would 
reproduce measured water levels and estimated discharge in the province, but would result in different patterns of ground-water flow and different configurations of flow-region boundaries.

The simulation results presented in this report are only approximate because of uncertainties in the quantity of recharge to and evapotranspiration from the aquifers in the province and because the extent, thickness, and hydraulic properties of the carbonate aquifers are largely unknown. Nonetheless, several general conclusions can be made on the basis of available information and the model simulations:

- Most ground-water flow in the province is relatively shallow, moving from recharge areas in the mountain ranges to discharge areas in the adjacent valleys.

- Directions of shallow ground-water flow do not everywhere correspond to the directions of deep ground-water flow.

- Most consolidated rocks beneath the valleys and surrounding mountains are not highly transmissive, suggesting either that not all carbonate rocks are highly permeable or that not all valleys and surrounding mountains are underlain by carbonate rocks.

- Ground-water flow to the larger regional springs is through permeable carbonate rocks that transmit water from distant recharge areas beneath intervening mountains and valleys.

- Only small quantities of deep flow discharge at the terminal sinks (the Great Salt Lake, the Great Salt Lake Desert, the Railroad Valley and Death Valley playas, and the Colorado and Virgin Rivers); rather, most of the deep flow discharges at regional springs and in areas of evapotranspiration upgradient from the terminal sinks.

- Only small quantities of deep flow are simulated in the upper Humboldt River region, because most of the ground water discharging along the river is from local flow associated with the river.

The model is a simplification of flow through a geologically complex region, in which hydraulic properties can change abruptly because of changes in lithology. The lack of information on the extent of aquifers, their hydraulic properties, and the distribution of water levels in the aquifers precludes developing a model in which only one distribution of transmissivity is possible. The model, therefore, may not reliably predict water- level declines that would result from pumping ground water in the province nor simulate the rate of change in natural discharge caused by pumping. The model may be best suited for simulating different transmissivity distributions to evaluate potential source areas of regional springs and for simulating long-term effects of changing recharge and discharge on regional ground-water flow.

\section{REFERENCES CITED}

Arnow, Ted, 1984, Water-level and water-quality changes in Great Salt Lake, Utah, 1847-1983: U.S. Geological Survey Circular 913, $22 \mathrm{p}$.

Bedinger, M.S., Harrill, J.R., and Thomas, J.M., 1984, Maps showing ground-water units and withdrawal, Basin and Range province, Nevada: U.S. Geological Survey WaterResources Investigations Report 83-4119-A, 10 p., 2 plates, scale 1:500,000.

Bedinger, M.S., Sargent, K.A., and Langer, W.H., 1989, Studies of geology and hydrology in the Basin and Range province, southwestern United States, for isolation of highlevel radioactive waste-Characterization of the Death Valley region, Nevada and California: U.S. Geological Survey Professional Paper 1370-F, 49 p.

1990, Studies of geology and hydrology in the Basin and Range province, southwestern United States, for isolation of high-level radioactive waste-Characterization of the Bonneville region, Utah and Nevada: U.S. Geological Survey Professional Paper 1370-G, 38 p.

Bjorklund, L.J., Sumsion, C.T., and Sandberg, G.W., 1978, Ground-water resources of Parowan-Cedar City drainage basin, Iron County, Utah: Utah Department of Natural Resources Technical Publication 60, 93 p.

Blankennagel, R.K., and Weir, J.E., Jr., 1973, Geohydrology of the eastern part of Pahute Mesa, Nevada Test Site, Nye County, Nevada: U.S. Geological Survey Professional Paper 712-B, 35 p.

Bolke, E.L., and Sumsion, C.T., 1978, Hydrologic reconnaissance of the Fish Springs Flat area, Tooele, Juab, and Millard Counties, Utah: Utah Department of Natural Resources Technical Publication 64, $30 \mathrm{p}$.

Brenner, I.S., 1974, A surge of maritime tropical air-Gulf of California to the southwestern United States: Monthly Weather Review, v. 102, p. 375-389.

Bunch, R.L., and Harrill, J.R., 1984, Compilation of selected hydrologic data from the MX missile siting investigation, east-central Nevada and western Utah: U.S. Geological Survey Open-File Report 84-702, 123 p.

Carlton, S.M., 1985, Fish Springs multibasin flow system, Nevada and Utah: University of Nevada, Reno, Mackay School of Mines, M.S. thesis, $103 \mathrm{p}$.

Carpenter, Everett, 1915, Ground water in southeastern Nevada: U.S. Geological Survey Water-Supply Paper 365, 86 p.

Carr, W.J., 1984, Regional structural setting of Yucca Mountain, southwestern Nevada, and late Cenozoic rates of tectonic activity in part of the southwestern Great Basin, Nevada and California: U.S. Geological Survey Open-File Report 84-854, $114 \mathrm{p}$. 
Claassen, H.C., 1983, Sources and mechanisms of recharge for ground water in the west-central Amargosa Desert, Nevada-A geochemical interpretation: U.S. Geological Survey Open-File Report 83-542, 66 p.

Coney, P.J., 1980, Cordilleran metamorphic core complexesAn overview, in Crittenden, M.D., Jr., Coney, P.J., and Davis, G.K., eds., Cordilleran metamorphic core complexes: Geological Society of America Memoir 153, p. 7-31.

Cordova, R.M., 1970, Ground-water conditions in southern Utah Valley and Goshen Valley, Utah: Utah Department of Natural Resources Technical Publication 28, $72 \mathrm{p}$.

Cordova, R.M., and Subitzky, Seymour, 1965, Ground water in northern Utah Valley, Utah-A progress report for the period 1948-63: Utah State Engineer Technical Publication $11,41 \mathrm{p}$

Czarnecki, J.B., and Waddell, R.K., 1984, Finite-element simulation of ground-water flow in the vicinity of Yucca Mountain, Nevada-California: U.S. Geological Survey Water-Resources Investigations Report 84-4349, 38 p.

Dettinger, M.D., 1989, Distribution of carbonate-rock aquifers in southern Nevada and the potential for their development-Summary of findings, 1985-88: Carson City, Nev., Program for the Study and Testing of CarbonateRock Aquifers in eastern and southern Nevada, Summary Report No. 1, $37 \mathrm{p}$.

Dinwiddie, G.A., and Schroder, L.J., 1971, Summary of hydraulic testing in and chemical analyses of water samples from deep exploratory holes in Little Fish Lake, Monitor, Hot Creek, and Little Smoky Valleys, Nevada: U.S. Geological Survey Report USGS 474-90, 70 p. [Available only from National Technical Information Service, U.S. Department of Commerce, Springfield, VA 22161.]

Domenico, P.A., Stephenson, D.S., and Maxey, G.B., 1964, Ground water in Las Vegas Valley: University of Nevada, Desert Research Institute Technical Report H-W 7, 53 p.

Dudley, W.W., Jr., and Larson, J.D., 1976, Effect of irrigation pumping on desert pupfish habitats in Ash Meadows, Nye County, Nevada: U.S. Geological Survey Professional Paper 927, $52 \mathrm{p}$.

Eakin, T.E., 1960, Ground-water appraisal of Newark Valley, White Pine County, Nevada: Nevada Department of Conservation and Natural Resources, Ground-Water Resources - Reconnaissance Report 1, 33 p.

-1961a, Ground-water appraisal of Long Valley, White Pine and Elko Counties, Nevada: Nevada Department of Conservation and Natural Resources, Ground-Water Resources - Reconnaissance Report 3, 35 p.

1961b, Ground-water appraisal of Pine Valley, Eureka and Elko Counties, Nevada: Nevada Department of Conservation and Natural Resources, Ground-Water Resources - Reconnaissance Report 2, 41 p.

1963, Ground-water appraisal of Pahranagat and Pahroc Valleys, Lincoln and Nye Counties, Nevada: Nevada Department of Conservation and Natural Resources, GroundWater Resources - Reconnaissance Report 21, 36 p.

1966, A regional interbasin ground-water system in the White River area, southeastern Nevada: Water Resources Research, v. 1, no. 3, p. 251-271.

Eakin, T.E., Hughes, J.L., and Moore, D.O., 1967, Waterresources appraisal of Steptoe Valley, White Pine and Elko Counties, Nevada: Nevada Department of Conservation and Natural Resources, Water Resources - Reconnaissance Report 42, $48 \mathrm{p}$.

Eakin, T.E., and Lamke, R.D., 1966, Hydraulic reconnaissance of the Humboldt River Basin, Nevada: Nevada De- partment of Conservation and Natural Resources, Water Resources Bulletin 32, $107 \mathrm{p}$.

Eakin, T.E., Maxey, G.B., Robinson, T.W., Fredericks, J.C., and Loeltz, O.J., 1951, Contributions to the hydrology of eastern Nevada: Nevada State Engineer, Water Resources Bulletin 12, $171 \mathrm{p}$.

Eakin, T.E., and Moore, D.O., 1964, Uniformity of discharge of Muddy River Springs, southeastern Nevada, and relation to interbasin movement of ground water, in Geological Survey Research 1964: U.S. Geological Survey Professional Paper 501-D, p. D171-D176.

Eakin, T.E., Price, Don, and Harrill, J.R., 1976, Summary appraisals of the Nation's ground-water resources-Great Basin region: U.S. Geological Survey Professional Paper 813-G, $37 \mathrm{p}$.

Eakin, T.E., and Winograd, I.J., 1965, Interbasin movement of ground water in south-central Nevada-Some implications, in Abstracts for 1964: Geological Society of America Special Paper 82, p. 52.

Eaton, G.P., 1975, Characteristics of a transverse crustal boundary in the Basin and Range province of southern Nevada: Geological Society of America Abstracts with Programs, v. 7, no. 7, p. 1062.

Eaton, G.P., Wahl, R.R., Prostka, H.J., Mabey, D.R., and Kleinkopf, M.D., 1978, Regional gravity and tectonic patterns: Their relation to late Cenozoic epeirogeny and lateral spreading in the western Cordillera, in Smith, R.B., and Eaton, G.P., eds., Cenozoic tectonics and regional geophysics of the western Cordillera: Geological Society of America Memoir 152, p. 51-92.

Ekren, E.B., Bucknam, R.C., Carr, W.J., Dixon, G.L., and Quinlivan, W.D., 1976, East-trending structural lineaments in central Nevada: U.S. Geological Survey Professional Paper 986, 16 p.

Everett, D.E., and Rush, F.E., 1966, A brief appraisal of water resources of Grass and Carico Lake Valleys, Lander and Eureka Counties, Nevada: Nevada Department of Conservation and Natural Resources, Water Resources - Reconnaissance Report 37, 27 p.

Feltis, R.D., 1967, Ground-water conditions in Cedar Valley, Utah County, Utah: Utah Department of Natural Resources Technical Publication 16, $34 \mathrm{p}$.

Freeze, R.A., and Witherspoon, P.A., 1966, Theoretical analysis of regional groundwater flow-1. Analytical and numerical solutions to the mathematical model: Water Resources Research, v. 2, no. 4, p. 641-656.

1967, Theoretical analysis of regional groundwater flow-2. Effect of water-table configuration and subsurface permeability variation: Water Resources Research, v. 3 , no. 2 , p. $623-634$.

French, D.E., and Freeman, K.J., 1979, Tertiary volcanic stratigraphy and reservoir characteristics of Trap Spring field, Nye County, Nevada, in Newman, G.W., and Goode, H.D., eds., Basin and Range symposium and Great Basin field conference: Denver, Colo., Rocky Mountain Association of Geologists, Guide Book, p. 487-502.

Frisbie, H.R., La Camera, R.J., Riek, M.M., and Wood, D.B., 1985, Water resources data, Nevada, water year 1984: U.S. Geological Survey Water-Data Report NV-84-1, 247 p.

Garcia, K.T., Gortsema, G.C., Pennington, R.N., and Preissler, A.M., 1992, Water resources data, Nevada, water year 1991: U.S. Geological Survey Water-Data Report NV-91-1, 481 p.

Gates, J.S., 1984, Hydrogeology of northwestern Utah and adjacent parts of Idaho and Nevada: Utah Geologic Association Publication 13, p. 239-248. 
1987, Ground water in the Great Basin part of the Basin and Range Province, western Utah: Cenozoic geology of western Utah-Site for precious metal and hydrocarbon accumulations: Utah Geological Association, Publication 16, p. 75-89.

Gates, J.S., and Kruer, S.A., 1981, Hydrologic reconnaissance of the southern Great Salt Lake Desert and summary of the hydrology of west-central Utah: Utah Department of Natural Resources Technical Publication 71, 55 p.

Glancy, P.A., 1968a, Water-resources appraisal of Butte Valley, Elko and White Pine Counties, Nevada: Nevada Division of Water Resources, Reconnaissance Report 49, 50 p.

1968b, Water-resources appraisal of Mesquite-Ivanpah Valley area, Nevada and California: Nevada Division of Water Resources, Reconnaissance Report 46, $57 \mathrm{p}$.

Glancy, P.A., and Van Denburgh, A.S., 1969, Water-resources appraisal of the lower Virgin River Valley area, Nevada, Arizona, and Utah: Nevada Division of Water Resources, Reconnaissance Report 51, $87 \mathrm{p}$.

Guth, P.L., 1988, Superposed Mesozoic thrusts and Tertiary extension, northwestern Clark County, Nevada [abs.]: Geological Society of America, Abstracts with Programs, v. 20, no. 3, p. 165 .

Harbaugh, A.W., 1990, A computer program for calculating subregional water budgets using results from the U.S. Geological Survey modular three-dimensional finite-difference ground-water flow model: U.S. Geological Survey Open-File Report 90-392, 46 p.

Hardman, George, 1936, Nevada precipitation and acreages of land by rainfall zones: University of Nevada-Reno, Agriculture Experiment Station mimeograph paper, $10 \mathrm{p}$.

1965, Nevada precipitation map: University of NevadaReno, Agriculture Experiment Station, Bulletin 183, 57 p.

Harrill, J.R., 1968, Hydrologic response to irrigation pumping in Diamond Valley, Eureka and Elko Counties, Nevada, 1950-65: Nevada Department of Conservation and Natural Resources, Water Resources Bulletin 35, 85 p.

1971, Water-resources appraisal of the Pilot Creek Valley area, Elko and White Pine Counties, Nevada: Nevada Division of Water Resources, Reconnaissance Report 56, $46 \mathrm{p}$.

1976, Pumping and ground-water storage depletion in Las Vegas Valley, Nevada, 1955-74: Nevada Division of Water Resources, Bulletin 44, $70 \mathrm{p}$.

1986, Ground-water storage depletion in Pahrump Valley, Nevada-California, 1962-75: U.S. Geological Survey Water-Supply Paper 2279, 53 p.

Harrill, J.R., Gates, J.S., and Thomas, J.M., 1988, Major ground-water flow systems in the Great Basin region of Nevada, Utah, and adjacent States: U.S. Geological Survey Hydrologic Investigations Atlas HA-694-C, 2 sheets.

Harrill, J.R., Welch, A.H., Prudic, D.E., Thomas, J.M., Carman, R.L., Plume, R.W., Gates, J.S., and Mason, J.L., 1983, Aquifer systems in the Great Basin region of $\mathrm{Ne}$ vada, Utah, and adjacent states-A study plan: U.S. Geological Survey Open-File Report 82-445, 49 p.

Hess, J.W., and Mifflin, M.D., 1978, A feasibility study of water production from deep carbonate aquifers in Nevada: University of Nevada, Desert Research Institute Publication 41054, $125 \mathrm{p}$.

Hildenbrand, T.G., and Kucks, R.P., 1982, A description of colored gravity maps of the Basin and Range Province, southwestern United States: U.S. Geological Survey OpenFile Report 82-500, 18 p.

Hintze, L.F., 1973, Geologic map of Utah: Utah Geologic and Mineralogic Survey, scale 1:500,000.
Holmes, W.R., 1984, Ground-water hydrology and projected effects of ground-water withdrawals in the Sevier Desert, Utah: Utah Department of Natural Resources Technical Publication 79, 54 p.

Hood, J.W., Price, Don, and Waddell, K.M., 1969, Hydrologic reconnaissance of Rush Valley, Tooele County, Utah: Utah Department of Natural Resources Technical Publication $23,63 \mathrm{p}$.

Hood, J.W., and Rush, F.E., 1965, Water-resources appraisal of the Snake Valley area, Utah and Nevada: Nevada Department of Conservation and Natural Resources, Water Resources - Reconnaissance Report 34, $43 \mathrm{p}$.

Hood, J.W., and Waddell, K.M., 1968, Hydrologic reconnaissance of Skull Valley, Tooele County, Utah: Utah Department of Natural Resources Technical Publication 18, $54 \mathrm{p}$.

1969, Hydrologic reconnaissance of Deep Creek Valley, Tooele and Juab Counties, Utah, and Elko and White Pine Counties, Nevada: Utah Department of Natural Resources Technical Publication 24, $54 \mathrm{p}$.

Houghton, J.G., 1967, Characteristics of rainfall in the Great Basin: University of Nevada, Desert Research Institute, $205 \mathrm{p}$.

Hubbs, C.L., and Miller, R.R., 1948, The Great Basin with emphasis on glacial and postglacial times, II-The zoological evidence: University of Utah Bulletin, v. 36, no. 20 , p. 17-166.

Hunt, C.B., and Robinson, T.W., 1960, Possible interbasin circulation of ground water in the southern part of the Great Basin, in Geological Survey Research 1960: U.S. Geological Survey Professional Paper 400-B, p. B273-B274.

Hunt, C.B., Robinson, T.W., Bowles, W.A., and Washburn, A.L., 1966, Hydrologic basin, Death Valley, California: U.S. Geological Survey Professional Paper 494-B, 138 p.

Jones, B.F., 1982, Mineralogy of fine grained alluvium from borehole U11G, expl. 1, northern Frenchman Flat area, Nevada Test Site: U.S. Geological Survey Open-File Report 82-765, $10 \mathrm{p}$.

Kirk, S.T., and Campana, M.E., 1990, A deuterium-calibrated groundwater flow model of a regional carbonate-alluvial system: Journal of Hydrology, v. 119, p. 357-388.

Kohler, M.A., Nordenson, T.J., and Baker, D.R., 1959, Evaporation maps for the United States: U.S. Department of Commerce, Weather Bureau Technical Paper 37, 13 p.

Loeltz, O.J., 1960, Source of water issuing from springs in Ash Meadows Valley, Nye County, Nevada [abs.]: Geological Society of America Bulletin, v. 71, no. 12, part 2, p. 19171918.

Lohman, S.W., 1972, Ground-water hydraulics: U.S. Geological Survey Professional Paper 708, 70 p.

Malmberg, G.T., 1965, Available water supply of the Las Vegas ground-water basin, Nevada: U.S. Geological Survey Water-Supply Paper 1780, $116 \mathrm{p}$.

Malmberg, G.T., and Eakin, T.E., 1962, Ground-water appraisal of Sarcobatus Flat and Oasis Valley, Nye and Esmeralda Counties, Nevada: Nevada Department of Conservation and Natural Resources, Ground-Water Resources - Reconnaissance Report 10, 39 p.

Mason, J.L., (in press), Ground-water hydrology and simulated effects of development in the Milford area, an arid basin in southwestern Utah: U.S. Geological Survey Professional Paper 1409-G.

Maxey, G.B., and Eakin, T.E., 1949, Ground water in White River Valley, White Pine, Nye, and Lincoln Counties, Nevada: Nevada State Engineer, Water Resources Bulletin $8,59 \mathrm{p}$.

Maxey, G.B., and Jameson, C.H., 1948, Geology and water 
resources of Las Vegas, Pahrump, and Indian Springs Valleys, Clark and Nye Counties, Nevada: Nevada State Engineer, Water Resources Bulletin 5, 292 p.

McDonald, M.G., and Harbaugh, A.W., 1988, A modular threedimensional finite-difference ground-water flow model: U.S. Geological Survey Techniques of Water-Resources Investigations, Book 6, Chapter A1, 586 p.

McKee, E.H., 1976, Geology of the northern part of the Toquima Range, Lander, Eureka, and Nye Counties, Nevada: U.S. Geological Survey Professional Paper 931, 49 p.

Meinzer, O.E., 1917, Geology and water resources of Big Smoky, Clayton, and Alkali Spring Valleys, Nevada: U.S. Geological Survey Water-Supply Paper 423, 167 p.

Mendenhall, W.C., 1909, Some desert watering places in southeastern California and southwestern Nevada: U.S. Geological Survey Water-Supply Paper 224, 86 p.

Mifflin, M.D., 1968, Delineation of ground-water flow systems in Nevada: University of Nevada, Desert Research Institute Technical Report H-W 4, 112 p.

1988, Region 5, Great Basin, in Back, W., Rosenshein, J.S., and Seaber, P.R., eds., Hydrogeology: Boulder, Colo., Geological Society of America, The Geology of North America, v. 0-2, p. 69-78, pl. 3, scale $1: 1,000,000$.

Mifflin, M.D., and Hess, J.W., 1979, Regional carbonate flow systems in Nevada, in Back, William, and Stephenson, D.A., eds., Contemporary hydrogeology, the George Burke Maxey memorial volume: Journal of Hydrology, v. 43, p. 217-237.

Miller, G.A., 1977, Appraisal of the water resources of Death Valley, California-Nevada: U.S. Geological Survey OpenFile Report 77-728, 68 p.

Morgan, D.S., and Dettinger, M.D., 1994, Ground-water conditions in Las Vegas Valley, Clark County, Nevada-Part II, Geohydrology and simulation of ground-water flow: U.S. Geological Survey Open-File Report 90-179, 151 p.

Mower, R.W., 1965, Ground-water resources of Pavant Valley, Utah: U.S. Geological Survey Water-Supply Paper 1794, 78 p. 1978, Hydrology of Beaver Valley area, Beaver County, Utah, with emphasis on ground water: Utah Department of Natural Resources Technical Publication 63, $90 \mathrm{p}$.

1982, Hydrology of the Beryl-Enterprise area, Escalante Desert, Utah, with emphasis on ground water: Utah Department of Natural Resources Technical Publication 73, $66 \mathrm{p}$.

Mower, R.W., and Cordova, R.M., 1974, Water resources of the Milford area, Utah, with special emphasis on ground water: Utah Department of Natural Resources Technical Publication 43, 105 p.

Mower, R.W., and Feltis, R.D., 1968, Ground-water hydrology of the Sevier Desert, Utah: U.S. Geological Survey Water-Supply Paper 1854, 75 p.

Naff, R.L., Maxey, G.B., and Kaufmann, R.F., 1974, Interbasin ground-water flow in southern Nevada: Nevada Bureau of Mines and Geology Report 20, 28 p.

Nolan, T.B., 1943, The Basin and Range Province in Utah, Nevada, and California: U.S. Geological Survey Professional Paper 197-D, $55 \mathrm{p}$.

Plume, R.W., 1989, Use of aeromagnetic data to define boundaries of a carbonate-rock aquifer in east-central Nevada, in Subitzky, Seymour, ed., Selected papers in the hydrologic sciences: U.S. Geological Survey Water-Supply Paper 2330, p. 1-10.

1995, Hydrogeologic framework of the Great Basin region of Nevada, Utah, and adjacent States: U.S. Geological Survey Professional Paper 1409-B, $64 \mathrm{p}$.

Plume, R.W., and Carlton, S.M., 1988, Hydrogeology of the Great Basin region of Nevada, Utah, and adjacent States:
U.S. Geological Survey Hydrologic Investigations Atlas HA694-A, 1 sheet.

Pollock, D.W., 1989, Documentation of computer programs to compute and display pathlines using results from the U.S. Geological Survey modular three-dimensional finitedifference ground-water flow model: U.S. Geological Survey Open-File Report 89-381, 188 p.

Poole, F.G., and Claypool, G.E., 1984, Petroleum source-rock potential and crude-oil correlation in the Great Basin, in Woodward, Jane, Meissner, F.F., and Layton, J.L., eds., Hydrocarbon source rocks of the Greater Rocky Mountain region: Denver, Colo., Rocky Mountain Association of Geologists, p. 179-229.

Rantz, S.E., 1972, Mean annual precipitation in California region: U.S. Geological Survey Open-File Map, scale $1: 1,000,000$.

Razem, A.C., and Steiger, J.I., 1981, Ground-water conditions in Tooele Valley, Utah, 1976-78: Utah Department of Natural Resources Technical Publication 69, $95 \mathrm{p}$.

ReMillard, M.D., Andersen, G.C., Birdwell, G.A., and Sandberg, G.W., 1986, Water resources data, Utah, water year 1985: U.S. Geological Survey Water-Data Report UT$85-1,400 \mathrm{p}$.

Roberts, R.J., 1964, Economic geology, mineral and water resources of Nevada: U.S. 88th Congress, second session, Senate Document 87, p. 39-48.

1966, Metallogenic provinces and mineral belts in $\mathrm{Ne}-$ vada, in AIME Pacific Southwest Mineral Industry Conference, Sparks, Nevada, 1965, Papers, part A: Nevada Bureau of Mines Report 13, p. 47-52.

Rowan, L.C., and Wetlaufer, P.H., 1981, Relation between regional lineament systems and structural zones in $\mathrm{Ne}-$ vada: American Association of Petroleum Geologists Bulletin, v. 65 , no. 8, p. 1414-1432.

Rowley, P.D., Lipman, P.W., Mehnert, H.H., Lindsey, D.A., and Anderson, J.J., 1978, Blue Ribbon lineament, an easttrending structural zone within the Pioche Mineral Belt of southwestern Utah and eastern Nevada: U.S. Geological Survey Journal of Research, v. 6, no. 2, p. 175-192.

Rush, F.E., 1964, Ground-water appraisal of the Meadow Valley area, Lincoln and Clark Counties, Nevada: Nevada Department of Conservation and Natural Resources, Ground-Water Resources - Reconnaissance Report 27, 43 p. 1968a, Water-resources appraisal of Clayton ValleyStonewall Flat area, Nevada and California: Nevada Department of Conservation and Natural Resources, Water Resources - Reconnaissance Report 45, 54 p.

$-1968 \mathrm{~b}$, Water-resources appraisal of the Lower MoapaLake Mead area, Clark County, Nevada: Nevada Division of Water Resources, Reconnaissance Report 50, 66 p.

-1968c, Water-resources appraisal of Thousand Springs Valley, Elko County, Nevada: Nevada Division of Water Resources, Reconnaissance Report 47, 61 p.

1970, Regional ground-water systems in the Nevada Test Site area, Nye, Lincoln, and Clark Counties, Nevada: Nevada Division of Water Resources, Reconnaissance Report $54,25 \mathrm{p}$.

Rush, F.E., and Eakin, T.E., 1963, Ground-water appraisal of Lake Valley in Lincoln and White Pine Counties, Nevada: Nevada Department of Conservation and Natural Resources, Ground-Water Resources - Reconnaissance Report $24,29 \mathrm{p}$.

Rush, F.E., and Everett, D.E., 1964, Ground-water appraisal of Monitor, Antelope, and Kobeh Valleys, Nevada: Nevada Department of Conservation and Natural Resources, Ground- 
Water Resources - Reconnaissance Report 30, 42 p. 1966a, Water-resources appraisal of Little Fish Lake, Hot Creek, and Little Smoky Valleys, Nevada: Nevada Department of Conservation and Natural Resources, Water Resources - Reconnaissance Report 38, 38 p.

$1966 \mathrm{~b}$, Water-resources appraisal of the Huntington Valley area, Elko and White Pine Counties, Nevada: Nevada Department of Conservation and Natural Resources, Water Resources - Reconnaissance Report 35, 37 p.

Rush, F.E., and Huxel, C.J., Jr., 1966, Ground-water appraisal of the Eldorado-Piute Valley area, Nevada and California: Nevada Department of Conservation and Natural Resources, Water Resources - Reconnaissance Report 36, $30 \mathrm{p}$.

Rush, F.E., and Kazmi, S.A.T., 1965, Water resources appraisal of Spring Valley, White Pine and Lincoln Counties, Nevada: Nevada Department of Conservation and Natural Resources, Water Resources - Reconnaissance Report 33, $36 \mathrm{p}$.

Rush, F.E., and Schroer, C.V., 1970, Water resources of Big Smoky Valley, Lander, Nye, and Esmeralda Counties, Nevada: Nevada Division of Water Resources, Bulletin 41, $84 \mathrm{p}$.

Saltus, R.W., 1984, A description of colored gravity and terrain maps of the southwestern Cordillera: U.S. Geological Survey Open-File Report 84-95, $16 \mathrm{p}$.

Shane, D.R., and Stewart, J.H., 1976, Ore deposits as related to tectonics and magnetism, Nevada and Utah: American Institute of Metallurgical and Petroleum Engineers Transactions, v. 260, p. 225-232.

Stephens, J.C., 1974a, Hydrologic reconnaissance of the northern Great Salt Lake Desert and summary of hydrologic reconnaissance of northwestern Utah: Utah Department of Natural Resources Technical Publication 42, $55 \mathrm{p}$.

1974b, Hydrologic reconnaissance of the Wah Wah Valley drainage basin, Millard and Beaver Counties, Utah: Utah Department of Natural Resources Technical Publication $47,53 \mathrm{p}$.

1976, Hydrologic reconnaissance of the Pine Valley drainage basin, Millard, Beaver, and Iron Counties, Utah: Utah Department of Natural Resources Technical Publication $51,38 \mathrm{p}$.

-1977, Hydrologic reconnaissance of the Tule Valley drainage basin, Juab and Millard Counties, Utah: Utah Department of Natural Resources Technical Publication $56,37 \mathrm{p}$.

Stewart, J.H., 1980, Geology of Nevada-A discussion to accompany the geologic map of Nevada: Nevada Bureau of Mines and Geology Special Publication 4, $136 \mathrm{p}$.

Stewart, J.H., and Carlson, J.E., 1978, Geologic map of Nevada: U.S. Geological Survey, scale 1:500,000.

Stewart, J.H., Moore, W.J., and Zietz, Isidore, 1977, Eastwest patterns of Cenozoic igneous rocks, aeromagnetic anomalies, and mineral deposits, Nevada and Utah: Geological Society of America Bulletin, v. 88, p. 67-77.

Stewart, J.H., Walker, G.W., and Kleinhampl, F.J., 1975, Oregon-Nevada lineament: Geology, v. 3, no. 5, p. 265-268.

Stillwater, R., Kraeger-Rovey, C., and Scott, P., 1992, Technical note on MODFLOW notation: Ground Water, v. 30, no. 4 , p. 613 .

Sumsion, C.T., and others, 1976, Ground-water conditions in Utah, spring of 1976: Utah Division of Water Resources Cooperative Investigations Report $15,69 \mathrm{p}$.

Thomas, J.M., 1988, Delineation of regional ground-water flow systems in southern Nevada using isotopic and chemical data [abs.]: Geological Society of America, Abstracts with Programs, v. 20, no. 7, p. A363.
Thomas, J.M., Lyles, B.F., and Carpenter, L.A., 1991, Chemical and isotopic data for water from wells, springs and streams in carbonate-rock terrane of southern and eastern $\mathrm{Ne}$ vada and southeastern California, 1985-1988: U.S. Geological Survey Open-File Report 89-422, 24 p.

Thomas, J.M., Mason, J.L., and Crabtree, J.D., 1986, Groundwater levels in the Great Basin region of Nevada, Utah, and adjacent States: U.S. Geological Survey Hydrologic Investigations Atlas HA-694-B, 2 sheets.

Thomas, J.M., Schaefer, D.H., and Dettinger, M.D., 1990 , Use of geochemical data to trace ground-water flow which could affect oil migration in carbonate-rock aquifers of eastern Great Basin, Nevada and Utah [abs.], in Flanigan, D.M.H., Garside, L.J., and Hansen, Mike, eds., Oil fields and geology of the Pine Valley, Eureka County area, Nevada: Reno, Nev., Nevada Petroleum Society, Inc., 1990 Fieldtrip Guidebook, 74 p.

Tóth, J., 1962, A theory of ground-water motion in small drainage basins in central Alberta, Canada: Journal of Geophysical Research, v. 67, no. 11, p. 4375-4387.

1963, A theoretical analysis of ground-water flow in small drainage basins: Journal of Geophysical Research, v. 68 , no. 16 , p. $4795-4812$.

Trudeau, D.A., Hess, J.W., and Jacobsen, R.L., 1983, Hydrogeology of the Littlefield Springs, Arizona: Ground Water, v. 21, no. 3, p. 325-333.

U.S. Bureau of the Census, 1913, General report and analysis: U.S. Government Printing Office, Population 1910, v. $1,1369 \mathrm{p}$.

1921, Number and distribution of inhabitants: U.S. Government Printing Office, Population 1920, v. 1, 695 p.

1952, Number of inhabitants: U.S. Government Printing Office, Census of population 1950, v. 1, $1351 \mathrm{p}$.

1983, United States summary: U.S. Government Printing Office, 1980 Census of Population, v. 1, chap. A, pt. $1,284 \mathrm{p}$.

1991a, Summary, population and housing characteristics, Nevada: U.S. Government Printing Office, 1990 Census of Population and Housing, $1990 \mathrm{CPH}-1-30,94 \mathrm{p}$.

1991b, Summary, population and housing characteristics, Utah: U.S. Government Printing Office, 1990 Census of Population and Housing, $1990 \mathrm{CPH}-1-46,141 \mathrm{p}$.

U.S. Weather Bureau, 1963, Normal annual precipitation, normal May-September precipitation, 1931-1960, State of Utah: Utah State Engineer map, scale 1:500,000.

1965, Mean annual precipitation, 1930-57, State of Idaho: U.S. Soil Conservation Service in cooperation with the U.S. Weather Bureau.

Van Denburgh, A.S., and Rush, F.E., 1974, Water resources appraisal of Railroad and Penoyer Valleys, east-central Nevada: Nevada Division of Water Resources, Reconnaissance Report $60,61 \mathrm{p}$.

van Hylckama, T.E.A., 1974, Water use by saltcedar as measured by the water budget method: U.S. Geological Survey Professional Paper 491-E, $30 \mathrm{p}$.

Waddell, K.M., Seiler, R.L., Santini, Melissa, and Solomon, D.K., 1987, Ground-water conditions in Salt Lake Valley, Utah, 1969-83, and predicted effects of increased withdrawals from wells: Utah Department of Natural Resources Technical Publication 87, 69 p.

Waddell, R.K., 1982, Two-dimensional steady-state model of ground-water flow, Nevada Test Site and vicinity, NevadaCalifornia: U.S. Geological Survey Water-Resources Investigations Report 82-4085, $72 \mathrm{p}$.

Waddell, R.K., Robison, J.H., and Blankennagel, R.K., 1984, 
Hydrology of Yucca Mountain and vicinity, Nevada-California-Investigative results through mid-1983: U.S. Geological Survey Water-Resources Investigations Report 84-4267, $72 \mathrm{p}$.

Walker, G.E., and Eakin, T.E., 1963, Geology and ground water of Amargosa Desert, Nevada-California: Nevada Department of Conservation and Natural Resources, Ground-Water Resources - Reconnaissance Report 14, 57 p.

Watson, Phil, Sinclair, Peter, and Waggoner, Ray, 1976, Quantitative evaluation of a method for estimating recharge to the desert basins of Nevada: Journal of Hydrology, $v$. 31, p. 335-357.

Welch, A.H., and Thomas, J.M., 1984, Aqueous geochemistry and isotope hydrology of the White River system, eastern Nevada [abs.]: Geological Society of America, Abstracts with Programs, v. 16 , no. 6, p. 689.

Wernicke, Brian, and Axen, G.J., 1988, Basin and Range extensional tectonics at the latitude of Las Vegas, Nevada: Geological Society of America Bulletin, v. 100, p. 1738-1757.

Wernicke, Brian, Guth, P.L., and Axen, G.J., 1984, Tertiary extension in the Sevier thrust belt of southern Nevada, in Lintz, Joseph, Jr., ed., Western geological excursions [in conjunction with the 1984 annual meetings of Geological Society of America and affiliated societies]: University of Nevada, Reno, Mackay School of Mines, v. 4, p. 473-510.

Williamson, A.K., Prudic, D.E., and Swain, L.A., 1989, Groundwater flow in the Central Valley, California: U.S. Geological Survey Professional Paper 1401-D, 127 p.

Winograd, I.J., 1962, Interbasin movement of ground water at the Nevada Test Site, Nevada, in Short papers in geology, hydrology, and topography: U.S. Geological Survey Professional Paper 450-C, p. C108-C111.

1963, A summary of the ground-water hydrology of the area between the Las Vegas Valley and the Amargosa Desert, Nevada, with special reference to the effects of possible new withdrawals of ground water: U.S. Geological Survey Open-File Report TEI-840, 79 p.

1971, Hydrogeology of ash-flow tuff-A preliminary statement: Water Resources Research, v. 7, no. 4, p. 994-1006.

Winograd, I.J., and Eakin, T.E., 1965, Interbasin movement of ground water in south-central Nevada-The evidence, in Abstracts for 1964: Geological Society of America Special Paper 82, p. 227.

Winograd, I.J., and Friedman, Irving, 1972, Deuterium as a tracer of regional ground-water flow, southern Great Basin, Nevada and California: Geological Society of America Bulletin, v. 83, no. 12, p. 3691-3708.

Winograd, I.J., and Pearson, F.J., Jr., 1976, Carbon 14 anomaly in a regional carbonate aquifer-Possible evidence for megascale channeling, south-central Great Basin: Water Resources Research, v. 12, no. 6, p. 1125-1143.

Winograd, I.J., and Szabo, B.J., 1986, Water-table decline in the south-central Great Basin during the Quaternary period-Implications for toxic waste disposal: U.S. Geological Survey Open-File Report 85-697, 18 p.

Winograd, I.J., and Thordarson, William, 1968, Structural control of ground-water movement in miogeosynclinal rocks of southcentral Nevada, in Eckel, E.B., ed., Nevada Test Site: Geological Society of America Memoir 110, p. 35-48.

1975, Hydrogeologic and hydrochemical framework, south-central Great Basin, Nevada-California, with special reference to the Nevada Test Site: U.S. Geological Survey Professional Paper 712-C, 126 p.

Zones, C.P., 1961, Ground-water potentialities in the Crescent Valley, Eureka and Lander Counties, Nevada: U.S. Geological Survey Water-Supply Paper 1581, 50 p. 




\section{SELECTED SERIES OF U.S. GEOLOGICAL SURVEY PUBLICATIONS}

\section{Periodicals}

Earthquakes \& Volcanoes (issued bimonthly).

Preliminary Determination of Epicenters (issued monthly).

\section{Technical Books and Reports}

Professional Papers are mainly comprehensive scientific reports of wide and lasting interest and importance to professional scientists and engineers. Included are reports on the results of resource studies and of topographic, hydrologic, and geologic investigations. They also include collections of related papers addressing different aspects of a single scientific topic.

Bulletins contain significant data and interpretations that are of lasting scientific interest but are generally more limited in scope or geographic coverage than Professional Papers. They include the results of resource studies and of geologic and topographic investigations, as well as collections of short papers related to a specific topic.

Water-Supply Papers are comprehensive reports that present significant interpretive results of hydrologic investigations of wide interest to professional geologists, hydrologists, and engineers. The series covers investigations in all phases of hydrology, including hydrogeology, availability of water, quality of water, and use of water.

Circulars present administrative information or important scientific information of wide popular interest in a format designed for distribution at no cost to the public. Information is usually of short-term interest.

Water-Resource Investigations Reports are papers of an interpretive nature made available to the public outside the formal USGS publications series. Copies are reproduced on request unlike formal USGS publications, and they are also available for public inspection at depositories indicated in USGS catalogs.

Open-File Reports include unpublished manuscript reports, maps, and other material that are made available for public consultation at depositories. They are a nonpermanent form of publication that may be cited in other publications as sources of information.

\section{Maps}

Geologic Quadrangle Maps are multicolor geologic maps on topographic bases in $71 / 2$ - or 15 -minute quadrangle formats (scales mainly $1: 24,000$ or 1:62,500) showing bedrock, surficial, or engineering geology. Maps generally include brief texts; some maps include structure and columnar sections only.

Geophysical Investigations Maps are on topographic or planimetric bases at various scales; they show results of surveys using geophysical techniques, such as gravity, magnetic, seismic, or radioactivity, which reflect subsurface structures that are of economic or geologic significance. Many maps include correlations with the geology.

Miscellaneous Investigations Series Maps are on planimetric or topographic bases of regular and irregular areas at various scales; they present a wide variety of format and subject matter. The series also includes $71 / 2$-minute quadrangle photogeologic maps on planimetric bases that show geology as interpreted from aerial photographs. Series also includes maps of Mars and the Moon.
Coal Investigations Maps are geologic maps on topographic or planimetric bases at various scales showing bedrock or surficial geology, stratigraphy, and structural relations in certain coal-resource areas.

Oil and Gas Investigations Charts show stratigraphic information for certain oil and gas fields and other areas having petroleum potential.

Miscellaneous Field Studies Maps are multicolor or black-andwhite maps on topographic or planimetric bases on quadrangle or irregular areas at various scales. Pre-1971 maps show bedrock geology in relation to specific mining or mineral-deposit problems; post-1971 maps are primarily black-and-white maps on various subjects, such as environmental studies or wilderness mineral investigations.

Hydrologic Investigations Atlases are multicolor or black-andwhite maps on topographic or planimetric bases presenting a wide range of geohydrologic data of both regular and irregular areas; principal scale is $1: 24,000$, and regional studies are at $1: 250,000$ scale or smaller.

\section{Catalogs}

Permanent catalogs, as well as some others, giving comprehensive listings of U.S. Geological Survey publications are available under the conditions indicated below from the U.S. Geological Survey, Books and Open-File Reports Sales, Federal Center, Box 25286, Denver, CO 80225. (See latest Price and Availability List.)

"Publications of the Geological Survey, 1879-1961" may be purchased by mail and over the counter in paperback book form and as a set of microfiche.

"Publications of the Geological Survey, 1962-1970" may be purchased by mail and over the counter in paperback book form and as a set of microfiche.

"Publications of the Geological Survey, 1971-1981" may be purchased by mail and over the counter in paperback book form (two volumes, publications listing and index) and as a set of microfiche.

Supplements for 1982,1983,1984, 1985, 1986, and for subsequent years since the last permanent catalog may be purchased by mail and over the counter in paperback book form.

State catalogs, "List of U.S. Geological Survey Geologic and Water-Supply Reports and Maps For (State)," may be purchased by mail and over the counter in paperback booklet form only.

"Price and Availability List of U.S. Geological Survey Publications," issued annually, is available free of charge in paperback booklet form only.

Selected copies of a monthly catalog "New Publications of the U.S. Geological Survey" are available free of charge by mail or may be obtained over the counter in paperback booklet form only. Those wishing a free subscription to the monthly catalog "New Publications of the U.S. Geological Survey" should write to the U.S. Geological Survey, 582 National Center, Reston, VA 22092.

Note.-Prices of Government publications listed in older catalogs, announcements, and publications may be incorrect. Therefore, the prices charged may differ from the prices in catalogs, announcements, and publications. 


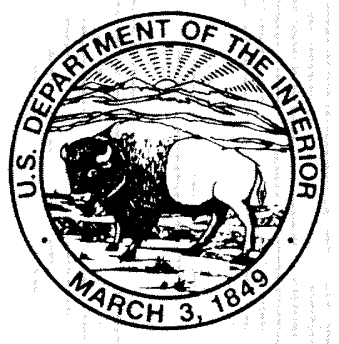

6
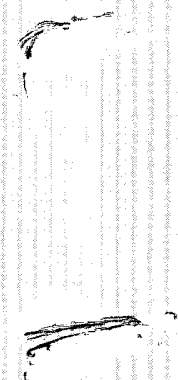

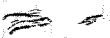

!

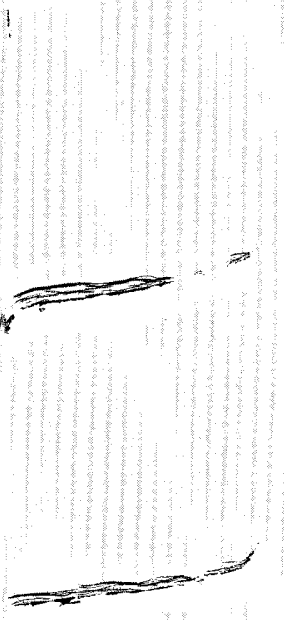

